Claremont Colleges

Scholarship@ Claremont

Summer 2018

\title{
Grassroots Impacts on the Civil Rights Movement: Christian Women Leaders' Contributions to the Paradigm Shift in the Tactics of the Southern Christian Leadership Conference and Its Affiliates
}

Wook Jong Lee

Follow this and additional works at: https://scholarship.claremont.edu/cgu_etd

Part of the History of Christianity Commons

\section{Recommended Citation}

Lee, Wook Jong. (2018). Grassroots Impacts on the Civil Rights Movement: Christian Women Leaders' Contributions to the Paradigm Shift in the Tactics of the Southern Christian Leadership Conference and Its Affiliates. CGU Theses \& Dissertations, 149. https://scholarship.claremont.edu/cgu_etd/149. doi: $10.5642 /$ cguetd/149

This Open Access Dissertation is brought to you for free and open access by the CGU Student Scholarship at Scholarship @ Claremont. It has been accepted for inclusion in CGU Theses \& Dissertations by an authorized administrator of Scholarship @ Claremont. For more information, please contact scholarship@cuc.claremont.edu. 
Grassroots Impacts on the Civil Rights Movement:

Christian Women Leaders' Contributions to the Paradigm Shift in the Tactics of the Southern Christian Leadership Conference and Its Affiliates

\author{
By Wook Jong Lee
}

\title{
Claremont Graduate University
}

2018

(C) Copyright Wook Jong Lee, 2018

All Rights Reserved 
ProQuest Number: 10844448

All rights reserved

INFORMATION TO ALL USERS

The quality of this reproduction is dependent upon the quality of the copy submitted.

In the unlikely event that the author did not send a complete manuscript and there are missing pages, these will be noted. Also, if material had to be removed, a note will indicate the deletion.

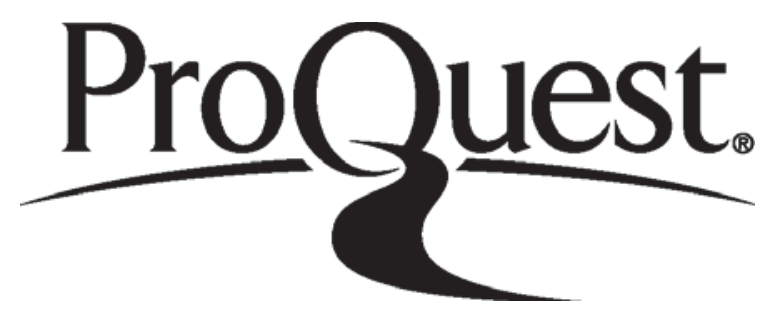

ProQuest 10844448

Published by ProQuest LLC (2018). Copyright of the Dissertation is held by the Author.

All rights reserved.

This work is protected against unauthorized copying under Title 17, United States Code Microform Edition (C) ProQuest LLC.

ProQuest LLC.

789 East Eisenhower Parkway

P.O. Box 1346

Ann Arbor, Ml $48106-1346$ 


\section{APPROVAL OF THE DISSERTATION COMMITTEE}

This dissertation has been duly read, reviewed, and critiqued by the Committee listed below, which hereby approves the manuscript of Wook Jong Lee as fulfilling the scope and quality requirements for meriting the degree of Doctor of Philosophy in Religion.

Patrick Q. Mason, Chair

Claremont Graduate University

Professor of Religion

Linda M. Perkins

Claremont Graduate University

Professor of Women's Studies

Monica A. Coleman

Claremont School of Theology

Professor of Theology 


\title{
Abstract \\ Grassroots Impacts on the Civil Rights Movement: Christian Women Leaders' Contributions to the Paradigm Shift in the Tactics of the Southern Christian Leadership Conference and Its Affiliates
}

\author{
By Wook Jong Lee \\ Claremont Graduate University: 2018
}

This dissertation examines the historical factors that built grassroots movements during the civil rights era of the United States. These movements were produced by Christian women leaders, and they influenced a crucial transition in the leadership of the civil rights movement. Through their training and mobilizing tactics, women civil rights leaders utilized grassroots leadership to help major civil rights organizations, such as SCLC, SNCC, CORE, COFO, and the NAACP, work closely with local black people in the South who struggled with their underprivileged circumstances. This project investigates the key role of the grassroots leadership of Christian women leaders, which led civil rights leaders to learn how to train and work together with local black people to desegregate voter registration and which drove their voting rights movement to succeed in achieving the Voting Rights Act of 1965. The nationwide successes of the Birmingham Campaign, the Freedom Summer Project, the St. Augustine Movement, and the Selma to Montgomery marches were essentially based on the Citizenship School, and Christian women leaders trained the major civil rights activists of these movements. This dissertation identifies the contributions of the women leaders' Citizenship School as key to these successes during the civil rights movement.

The grassroots leadership of the Christian women leaders was developed on the basis of their religious convictions for pursuing the beloved community. The concept of the beloved community, an integrated community, is founded in the black church tradition of freedom 
movements, which began during the slavery era. Using the Christian value of humanity as the children of God, women civil rights leaders developed the self-awareness of grassroots people in the local South and encouraged them to fight against social injustice with determined spirits for freedom. The Citizenship School of the women leaders transitioned the main stream of the civil rights movement from a focus on mass movements to the training and mobilizing of grassroots people in the South. By developing the individuality of grassroots people's efforts for civil rights, women civil rights leaders produced the multiple grassroots leaders who led the voting rights movement from 1960 to 1965 . The grassroots tactics of the Citizenship School provided the paradigm shift of the civil rights movement by transferring leadership from top, elite leaders to grassroots leaders during the voting rights movement. The grassroots tactics also played an essential role in breaking through the stagnation of the civil rights movement and mobilizing underprivileged local people in the South who could not pass the literacy exam for voter registration; the direct orders of the hierarchical leaders had not been able to motivate them to dedicate their lives to the voting rights movement. This dissertation provides historical evidence of this leadership transition and of women leaders' contributions to the transition, which led the civil rights movement to achieve success in desegregating voting rights. Moreover, this historical research demonstrates that the Christian faith of the grassroots women leaders, based in the tradition of the black church, contributed to the unification of diverse civil rights organizations in the pursuit of common goals for the voting rights of grassroots people and for building the beloved community during the civil rights movement era. 
In dedication to my beloved daughter,

Theophilia Sinae Lee

12.04.2008-12.19.2008

When the white snow is falling down, I am roaming around the field,

Going for a visit to the path with memory of my old love.

On one spring day when the snow is melting down,

On the green leaf, my old love, your image remains for all eternity.

Young Hoon Lee, Old Love 


\section{Acknowledgements}

Three years have passed since I reached PhD candidacy, and I have worked hard collecting original sources and finishing this dissertation. Despite this heavy work, I could not miss engaging in the candlelight vigils of over ten million people who gathered in Gwangwhamun Plaza in Seoul, South Korea. During the one hundred thirty days of demonstrations on the street, President Park Geun-hye finally was impeached, and the farmer Pak Nam Gi and the diver Kim Gwan Hong were murdered by social evil as martyrs in the circumstances of the demonstration. I was in the middle of the people's movement in Seoul while I was writing about the civil rights movement and the martyrs of the movement. I realized that the more people's demanding is sublime, the more people's lives are inevitably sacrificed. This is the lamentable truth of our human society, which suffers from the illnesses of social evil. The grassroots movements during the civil rights movement in American history were victorious and also regrettable.

First, I am thankful to the African American civil rights activists who inspired me to write and to practice this victorious and regrettable journey for human rights. I am especially thankful to Dorothy Cotton, who recently passed away but who encouraged my dissertation writing and allowed me to have an interview with her for this research a few months ago. I thank my wonderful dissertation committee members: Dr. Patrick Q. Mason, who has advised and taught me to be a professional historian in American religions since 2011; Dr. Linda M. Perkins, who inspired me to research the women civil rights leaders and who introduced me to the broader field of the African American history of women; and Dr. Monica A. Coleman, who taught me about the African American womanist movement and black theology. Due to their great teachings, I have been able to write a better quality dissertation. 
I give thanks to Dr. Sydney J. Lemelle at Pomona College, who introduced me to diverse perspectives on radical African American movements. I want to thank to Dr. M. Shawn Copeland at Boston College, who taught me about African religions; I will never forget her teachings. I am grateful to Dean Imani-Sheila Newsome-Camara, who advised me to write about the African American history of the Great Migration era while I studied at Boston University. I am grateful to the archivists of the King Center, Cynthia P. Lewis and Elaine Hall, the best archivists I ever met; with their help, I could wrestle with the original writings of Septima Clark, Ella Baker, and Dorothy Cotton. I also want to thank Ryan Hendrickson of the Howard Gotlieb Archival Research Center at Boston University and the archivists of the Highlander Research and Education Center in Tennessee.

I give my love to Rev. Dr. Wesley A. Roberts and the congregation of the People's Baptist Church in Boston, the oldest African American church in New England, for their fellowship and hospitality while my family was members of that church. I am grateful to the bereaved families of the Sewol ferry disaster, who led me to realize the responsibility to fight against social evil as a disciple of Jesus. I specially thank the members of the Church of Peace in Los Angeles, particularly Rev. Dr. Keedae Kim, Linda Lee, Yeni Han, Ki Byung Jang, Myung Gi Jung and Ho Hwang who have fought for human rights in Korea along with me. I thank my present church, Hyanglin Church in Seoul, Korea, which is a representative church of minjung and has pursued the path of Jesus with me. I also thank my friend Dr. Choi Phil Soo of Sejong University, who shared his professor's office with me as a place to write this and keep a number of books.

Most of all, I give my best love to my wife, Da Hyon Lyu, and my son, Samuel Kyuwhan Lee, who have been patient with my absence during the writing of this dissertation. Without their support, my studying would have been quickly futile. I am most thankful to my 
dad, Bom Jung Lee, and my mom, Sook Ryu, who have supported my studies and cared for my family. This dissertation is also a realization of my dad's dream because he could not make it in supporting my education so far. 


\section{Table of Contents}

Abstract

Dedication

Acknowledgements ................................................ vi

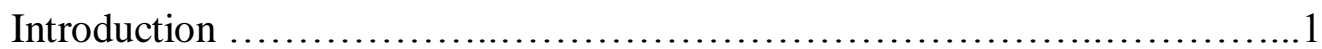

Chapter One: Origins and Debates about the Leadership of the Voting Rights Drive by the Southern Christian Leadership Conference from 1957 to 1960

Chapter Two: Reaching People at the Grass Roots:

The Citizenship Education Program of SCLC ..............66

Chapter Three: The Citizenship School's Women Leaders' Christian Thoughts and Practices for Grassroots Leadership ...............158

Chapter Four: The Citizenship School: From the Birmingham Campaign to the Selma to Montgomery Marches ..............................224

Conclusion.....................................................271

Epilogue......................................................273

Abbreviations.........................................................276

Appendix.......................................................277

Bibliography.....................................................28 


\section{Introduction}

In stories about the civil rights movement you hear mostly about the black ministers. But if you talk to the women who were there, you'll hear another story. I think the civil rights movement would never have taken off if some women hadn't started to speak up. A lot more are just getting to the place now where they can speak out. ${ }^{1}$

And I will put it like that - I don't want to give Martin . . . so much credit, that it sounds like he started us; he didn't. It started . . . as far as I'm concerned, Highlander Folk School is the root, is a base. . . Just play some songs and we would sing all the time, and then have a discussion about what the CEP, Citizenship Education Program, what it was all about, and it was all about the fact that we now had realized that they don't, none of them have a right to tell us what we can and cannot do. I am saying that it was awkwardly, 'cause I was none of them, you probably think, who was them. But it was, it was ... it was our need, for now, claiming our individuality. That's important. ${ }^{2}$

After the worldwide-known success of the Montgomery Bus Boycott in 1956, Martin Luther King, Jr., and the Southern Christian Leadership Conference (SCLC) struggled with expanding their movements for the civil rights of African Americans in the South. From 1957 to early 1960, SCLC and its president, King, focused on developing mass movements, such as the Crusade for Citizenship, which centered on gaining voting rights in major Southern areas, including Atlanta and Albany, Georgia; Birmingham, Alabama; St. Augustine, Florida; and Mississippi. Despite King's reputation for nonviolent protest in Montgomery, SCLC's movements during the early years came to be weakened by the decreased participation of local black people and the failure to attract the attention of the mass media. Besides the tenacious tyranny of white racists and police officers, King and SCLC's leaders confessed that their

1 Septima P. Clark, Ready from Within: Septima Clark and the Civil Rights Movement, ed. Cynthia Stokes Brown (Trenton: Africa World Press, 1990), 83.

2 "Interview with Dorothy Cotton," by Wook Jong Lee, March 28, 2018, New York, Appendix F. 
ambitions in Dixie for expanding the civil rights of African Americans faced the unexpected quagmire created by the apathy of local civil rights activists. ${ }^{3}$

During its initial years, SCLC had no solid tactics for a Southern-wide civil rights movement, and it had a weak fundraising system, thus, a lack of funds for hiring staffers. One of the crucial reasons for King's and SCLC's lack of progress with its mass movements from 1957 to 1961 was miscommunication between the leaders of SCLC and the local leaders and common people who had been struggling with their civil rights issues long before King's people came to join their movements. ${ }^{4}$ After this period of dissonance, King and SCLC leaders began to change their unilateral leadership structure, which focused on mass movements without considering the daily sufferings of local black people, such as the lack of reading abilities needed to pass literacy tests required to vote. About three years of disappointment led King and SCLC leaders to listen to the voices of women leaders who had diverse and seasoned experience in the civil rights movement. These were women who had been working to strengthen the autonomy of common black people. After applying the advice of women leaders, such as Ella Baker and Septima Poinsette Clark, to their tactics for reorganizing movements, King and other civil rights leaders were able to efficiently mobilize people in Birmingham, Mississippi, St. Augustine, and Selma and to successfully challenge President Lyndon B. Johnson to sign the Voting Rights Act of 1965. Moreover, King's leadership and the tactics of SCLC shifted from focusing on mass movements, which appealed to unspecified people to support them, to targeting specific

\footnotetext{
${ }^{3}$ King confronted local clergymen's criticisms that his movement was "unwise and untimely" and that his followers were "extremists." See "Letter from Birmingham Jail" in Martin Luther King, Jr., The Autobiography of Martin Luther King, Jr., ed. Clayborne Carson (New York: Warner Books, 1998), 188, 196, 198.

${ }^{4}$ King describes the way he came to join the civil rights movement as being "suddenly catapulted into" it. See King, The Autobiography, 199.
} 
institutions and local movements that could work closely with the lower classes and enforce cooperation between SCLC and the local people.

As King identified that he did not initiate the civil rights movement and was just a spokesman for the movement, this dissertation investigates how the voting rights movement was able to succeed in desegregating voter registration in $1965 .{ }^{5}$ If King was not the initiator or organizer of the voting rights movement, then there were specific people who made essential contributions to initiating and mobilizing the civil rights activists. This dissertation highlights the people who initiated and developed the voting rights movement. Even though the media focused on King's activities after his leadership of the Montgomery Bus Boycott, the nationwide movement for voting rights needed a different type of leadership because voting rights were based on individual determination. I analyze how individual determination to engage in the voting rights movement was able to be developed from the early part of 1960 to 1965 . To cooperate with the Student Nonviolent Coordinating Committee (SNCC) and local civil rights activists, SCLC needed to change King's single leadership model, which depended on mass movements. This dissertation analyzes how this leadership model of SCLC transitioned to multiple and horizontal leadership, that is, the grassroots leadership that was developed by the women civil rights activists who had been working with grassroots people in local areas before King emerged as the national leader of the civil rights movement.

The grassroots or bottom-up leadership model that led the civil rights movement to succeed in desegregating voter registration was continuously claimed by Christian women civil rights leaders, such as Ella Baker and Septima Clark. These women leaders also frequently insisted that King and SCLC had to change their authoritarian attitudes toward local civil rights

${ }^{5}$ King, The Autobiography of Martin Luther King, Jr., 80. 
activists. The women leaders had developed a different type of leadership, grassroots leadership, which encouraged any grassroot person to lead a civil rights movement who had a solid determined spirit for human rights. These women leaders highlighted that the determined spirit could only be achieved by education for self-awareness. This determined spirit was the reason why there were several martyrs and multiple leaders for civil rights during the 1960s, who worked without help from King's top-down leadership. This dissertation delves into the origins and methods of the efforts that enabled the development of the grassroots leadership and that led these multiple key leaders to mobilize the successful voting rights movement.

The voting rights movement of African Americans was the major activity of the civil rights movement from 1960 to 1965 . The major civil rights organizations, SCLC, SNCC, the Congress of Racial Equality (CORE), and the National Association for the Advancement of Colored People (NAACP), focused their major activities on voting rights during this period. After examining the status of local African Americans in terms of voter registration, these organizations commonly adopted the tactics of the Highlander Folk School's Citizenship School, which had developed grassroots tactics for increasing voter registration. The Christian women civil rights leaders, who had been ignored by the elite, male-dominated leadership of the movement, challenged local people and young civil rights activists to develop the Citizenship School program, which specialized in educating underprivileged people in the local areas of the South in self-awareness. This dissertation analyzes how the Christian women civil rights leaders developed the Citizenship School program that was adopted by the major civil rights organizations. Thus, this dissertation explains how the Christian women leaders' Citizenship School crucially contributed to the leadership transition of the civil rights movement from a single, top-down leadership approach to grassroots leadership. Moreover, this research examines 
how the religious backgrounds of the women leaders shaped their civil rights activities and tactics.

\section{Context and Purpose of the Study}

The media and historical researchers have previously limited women leaders' influence on the changing strategies of King and SCLC at the grassroots level to the initial stage of the establishment of the CEP during the early 1960s, and they have ignored women leaders' continual innovative impact that brought enthusiastic support from local people and resulted in a shifting of the center of the civil rights movement. The shifts caused by women leaders' innovations enabled major civil rights leaders to embrace Southern people's concerns and helped bring the civil rights movement to its triumphant years through the success of the voting rights marches in Selma. Moreover, most historical writings about the civil rights movement, such as David J. Garrow's Bearing the Cross: Martin Luther King, Jr. and the Southern Christian Leadership Conference and Taylor Branch's Parting the Waters: America in the King Years, 1954-63, have not highlighted how these women leaders developed and expanded the civil rights movement into nationwide movements for the social justice of impoverished people and how they provided a comprehensive vision of grassroots movements working for human dignity in an integrated community, the beloved community, during the civil rights movement era.

Concerning the religious origins of the civil rights movement, this dissertation compares the different church backgrounds of the civil rights leaders and how the traditional black Baptist church background of some influenced them to unify the direct action and nonviolent grassroots movements by mobilizing black churches, while leaders from the African Methodist Episcopal (AME) Church, such as Septima Clark and Rosa Parks, insisted on the practical priority of selfdetermination through encouraging individual resistance against social injustice. Rosetta E. 
Ross's Witnessing \& Testifying: Black Women, Religion, and Civil Rights and Lynne Olson's

Freedom's Daughters: The Unsung Heroines of the Civil Rights Movement from 1830 to 1970

concentrate on the individual religious convictions that motivated the civil rights leaders to have different philosophies about the tactics to use. Ross explains in her Witnessing \& Testifying,

As they became more important to the evolution of the Civil Rights Movement, Baker and Clark translated their parents' religious teaching on giving assistance into a focus on helping those most in need of assistance. While Baker emphasized organizing and Clark stressed educating, the signature of both women's work was seeking to empower local persons to take charge of and improve the quality of life in their communities. ${ }^{6}$

However, I assert that it is also relevant to examine how the civil rights leaders' different religious motivations were able to be united into a single purpose to guide the direction of the major activities of the civil rights movement and how unique religious beliefs caused the dynamics in the affiliates of the civil rights organizations.

This dissertation examines the women leaders' religious leadership that impacted the strategies and leadership of King, SCLC, and its affiliate organizations within the mainstream of the civil rights movement. I argue that Ella Baker, Septima Clark, Rosa Parks, Fannie Lou Hamer, Bernice Robinson, Dorothy Cotton, and Diane Nash shaped the watershed era of the civil rights movement by promoting voting rights among local, common people. Historical works such as David J. Garrow's Bearing the Cross and Michael Eric Dyson's I May Not Get There with You: The True Martin Luther King, Jr. have described the women leaders of the civil rights movement as helpers, triggers, advisers, narrators, and witnesses who stood by the major male leaders. ${ }^{7}$ I suggest that new images of the women leaders of the civil rights movement will shape

${ }^{6}$ Rosetta E. Ross, Witnessing \& Testifying: Black Women, Religion, and Civil Rights (Minneapolis: Fortress Press, 2003), 88.

${ }^{7}$ David J. Garrow, Bearing the Cross: Martin Luther King, Jr. and the Southern Christian Leadership Conference (New York: Perennial Classics, 1999), 84-88; and Michael Eric Dyson, I 
people's perspectives of the leadership of the women who created and led the prototypes of this historical movement.

I analyze the main problems with the approaches of King and the leaders of SCLC that led them into the quagmires that blocked the unification of local affiliate organizations with SCLC and the expansion of their social movements between 1957 and 1961. Besides external suppression of the civil rights movement by Southern police authorities, politicians, and racists, I determine that the main internal problem of the stagnated civil rights movements was the unilateral leadership style of King and SCLC leaders, which failed to respond to the real struggles of people and to empower local people to resist racists' oppression. I prove that King and SCLC began to escape from their own leadership problems by accepting women leaders' experience-based advice and by taking advantage of watershed moments to reshape their leadership tactics, thus gaining voting rights using the women leaders' strategies. Therefore, it is logical to locate the women leaders as the substantial leaders who ushered in the triumphant years of abolishing voter discrimination.

After the Albany Movement, King and SCLC were able to strive for broader goals that embraced the social problems of common people by practicing the women leaders' tactics and philosophy. In this dissertation, I focus on the major changes in the directions of King and SCLC after the Albany Movement and how their transitions accorded with the grassroots strategies of women leaders. I analyze how the influence of women leaders created shifts in the tactics, policies, and leadership structure of SCLC during and after the success of the Birmingham Campaign in 1963. Thomas F. Jackson captures the nature of the transition of SCLC in his From

May Not Get There with You: The True Martin Luther King, Jr. (New York: Simon \& Schuster, 2000), 127. 
Civil Rights to Human Rights: Martin Luther King, Jr., and the Struggle for Economic Justice. ${ }^{8}$

Jackson explains that the transition was based on the needs of black people for economic justice. However, voting rights promoted the economic justice of African Americans. This dissertation identifies how this transition happened and what caused the change in the main stream of the civil rights movement.

I focus on the male leadership approach of King and SCLC's leaders, which was based on their experiences in black churches as clergymen. ${ }^{9}$ During the Montgomery Bus Boycott, the intensive leadership of King and the soon-to-be SCLC leaders allowed them to have quick and effective connections with people at the ready. ${ }^{10}$ However, without having ready-to-use connections and strong public indignation among the broader populations of Southern cities, King and SCLC leaders lost their powerful leadership abilities to organize diverse people and social unions. Due to King's and SCLC's heavy focus on creating mass movements with topdown leadership, they had trouble unifying local affiliate organizations, which carried diverse banners of social needs and methodologies, and this dissonance enervated the dynamism of civil disobedience against racial discrimination from 1957 to 1961. The hierarchical tactics of King and SCLC were limited by the leaders' primary concerns, which were too idealistic to touch the underprivileged people's daily struggles. These leadership problems were rooted in the

8 Thomas F. Jackson, From Civil Rights to Human Rights: Martin Luther King, Jr., and the Struggle for Economic Justice (Philadelphia: University of Pennsylvania Press, 2007), 5.

9 The first nine executive board members of SCLC were clergymen of black churches except for Lawrence Reddick, a professor at Alabama State College. See "The SCLC Citizenship Workbook," The King Center, The Archive, http://www.thekingcenter.org/archive/document/sclc-citizenship-workbook (accessed Feb. 17, 2015).

10 Jo Ann Gibson Robinson describes how the boycott was well prepared by local social activists before King took on its leadership. See Jo Ann Gibson Robinson, The Montgomery Bus Boycott and the Women Who Started It: The Memoir of Jo Ann Gibson Robinson (Knoxville: The University of Tennessee, 1987), 50-51. 
hierarchical ways of connecting people that King and other leaders had learned from the clergy leadership style of black churches. The bottom-up leadership approach of grassroots movements allowed King and SCLC to change their unilateral leadership style in order to adopt better strategies that enabled these clergymen to embrace diverse people who struggled on a daily basis and to achieve the broader and higher goals of the civil rights movement at a nationwide level.

African American women leaders had different religious experiences. They had served local people as laity and had developed Christian charity movements for the poor, local affiliate organizations with the NAACP, and adult schools for citizenship that were linked to church connections. From their experiences with these social movements, which had different strategies from those of clergymen, women leaders were able to offer alternative strategies and leadership styles to King and SCLC. I examine how the bottom-up leadership style of the women leaders, which was based on their long-time Christian charity experiences and civil rights movements for local people, influenced King, SCLC leaders, SNCC leaders, and other major civil rights leaders to form a new paradigm of the civil rights movement that started with the grassroots level. I determine that this new paradigm was rooted in the religious movements of the women leaders and gave King and SCLC a breakthrough out of their dilemma of not being able to connect with people properly.

I provide a case study of the unique religious experiences that enabled women leaders to birth and develop their strategies for grassroots work and to lead the major civil rights leaders to develop the goals of the civil rights movement into the goals for human rights for the beloved community. In God's Long Summer: Stories of Faith and Civil Rights, Charles Marsh points out, "She [Fannie Lou Hamer] compared the student volunteers to the Good Samaritan, reading Jesus's famous parable as a description of the New Kingdom emerging amidst the scorched 
summer fields of the Mississippi Delta." ${ }^{11}$ Mostly laypeople in churches, the women leaders who were veterans of the civil rights movements had seasoned experience of leading diverse people to achieve goals beyond racial equality, thanks to their long-term leadership of Christian charity movements for economic and educational justice. I investigate how women leaders developed their bottom-up philosophy for serving people at the grassroots through Christian charity movements and local civil rights movements. Their abundant resources and experiences with civil rights groups, such as Ella Baker's SNCC, Septima Clark's and her cousin Bernice Robinson's Citizenship School, Dorothy Cotton's Citizenship Education Program (CEP) of SCLC, and Diane Nash's voting rights movements with local people, along with their diverse religious convictions and denominational traditions, created the keystone of the civil rights movement for building the beloved community and came to save the intolerant leadership of King and SCLC from people's apathy. I prove that women leaders' bottom-up strategies played a pivotal role in developing the civil rights movement.

Like many scholars, such as David Garrow and Howard Zinn, I have located the years 1957 to 1961 as the years of transition for King and SCLC, when they began to develop Southern-wide mass movements for voting rights following the success of the local movement of the Montgomery Bus Boycott. I also consider the Voting Rights Act of 1965 as the peak achievement of SCLC and other organizations combined. A historical writer on King, Garrow insists on the importance of historical research on the civil rights movement in Selma because that movement could well be the most important achievement of the civil rights era. ${ }^{12}$ Howard

11 Charles Marsh, God's Long Summer: Stories of Faith and Civil Rights (Princeton: Princeton University Press, 1997), 45.

12 Garrow, Bearing the Cross; and Garrow, Protest at Selma: Martin Luther King, Jr. and the Voting Rights Act of 1965 (New Haven: Yale University Press, 1978), xi. 
Zinn, an influential historian of American history and an activist of the civil rights movement, also highlights the pivotal point of the voting rights movement in Selma and Mississippi in his book, SNCC: The New Abolitionists. ${ }^{13}$ In this book he insists,

By early 1964, the number [SNCC activists in the Deep South] was up to 150. In the most heated days of abolitionism before the Civil War, there were never that many dedicated people who turned their backs on ordinary pursuits and gave their lives wholly to the movement. ${ }^{14}$

In his books, I May Not Get There With You: The True Martin Luther King, Jr. and April 4, 1968: Martin Luther King, Jr. 's Death and How It Changed America, Michael Eric Dyson introduces the ongoing debates between historians who support the idea that the top-down leadership style of King and others was effective and historians who insist that the hierarchal leadership approach had to be changed into a bottom-up one. ${ }^{15}$ Garrow argues that the downfall of SCLC's civil rights movement from 1957 to 1961 was primarily the result of strong suppression through police brutality and internal schism among civil rights leaders. He also asserts that the mass movement in Selma was the sole contributor to the Voting Rights Act of 1965. ${ }^{16}$ In this dissertation, I argue against these conclusions because these perspectives focus too much on external suppression and scandalous schisms among the major civil rights leaders, who did not confess their personal aspirations for fame, and not enough on internal leadership problems related to different tactics. Moreover, I focus on the diverse causes of the success of the voting rights movement in Selma. Was the success of the movement in Selma due to tepid police suppression and the lack of resistance from white racists? I highlight that the most variable

13 Howard Zinn, SNCC: The New Abolitionists (Cambridge: South End Press, 1964), 3.

14 Ibid.

15 Dyson, I May Not Get There with You, 206; and Dyson, April 4, 1968: Martin Luther King, Jr. 's Death and How It Changed America (New York: Basic Civitas Books, 2008), 148-149.

16 Garrow, Protest at Selma, 1-5. 
situation to change the social circumstances was how the demonstrators resisted oppression. I discuss why King and SCLC had trouble organizing the local demonstrators who were based in diverse organizations before the Selma movement and how they successfully unified these organizations in Selma through adopting women leaders' grassroots tactics. Moreover, I demonstrate that there were many previous local movements that had been consolidated into the voting rights movement in Selma. To analyze these historical causes and effects, I research the historical arguments regarding the leadership of the civil rights movement and local movements during this period and how the Christian women activists successfully organized the movement for voting rights in 1965 through the marches in Selma.

Concerning women leaders' pivotal roles in changing King's and SCLC leaders' leadership, the distinguished works on King and the civil rights movement, Taylor Branch's Parting the Waters: America in the King Years, 1954-63, Pillar of Fire: America in the King Years, 1963-65, and At Canaan's Edge: America in the King Years, 1965-68, comment on the influence of women's leadership on the decision-making of King and SCLC leaders. ${ }^{17}$ Bettye Collier-Thomas and V. P. Franklin argue for the independent role of women in the civil rights movement in Sisters in the Struggle: African American Women in the Civil Rights-Black Power Movement. ${ }^{18}$ Charles Marsh also highlights the important role of women leaders in the civil rights movement in God's Long Summer: Stories of Faith and Civil Rights and The Beloved Community: How Faith Shapes Social Justice, from the Civil Rights Movement to Today. In his

17 Taylor Branch, Parting the Waters: America in the King Years, 1954-63 (New York: Simon \& Schuster Paperbacks, 1988), 263; Branch, Pillar of Fire: America in the King Years, 1963-65 (New York: Simon \& Schuster Paperbacks, 1998), 105; and Branch, At Canaan's Edge: America in the King Years, 1965-68 (New York: Simon \& Schuster Paperbacks, 2006), 286.

18 Bettye Collier-Thomas and V. P. Franklin, eds., Sisters in the Struggle: African American Women in the Civil Rights-Black Power Movement (New York: New York University Press, 2001), 45. 
book, The Preacher King: Martin Luther King, Jr. and the Word that Moved America, Richard Lischer argues that King and SCLC were not the initiators of the civil rights movement; rather, they were crucial leaders in reshaping and declaring the meanings of the movement. Adam Fairclough focuses on the power of the charismatic leadership of King and SCLC in his volume, To Redeem the Soul of America: The Southern Christian Leadership Conference and Martin Luther King, Jr. ${ }^{19}$ Even though Branch, Collier-Thomas, Franklin, and Marsh introduce the important roles of women leaders in the civil rights movement, they define these leaders as merely helpers, motivators, or advisors. ${ }^{20}$ I suggest that the women leaders were not only the initiators but also the paradigm-shifters of the civil rights movement, despite the restraints of the hierarchical leadership of SCLC. However, the women grassroots leaders also were willing to work with the undeniable effects that were created by the national popularity of King and SCLC leaders, as Lischer insists.

Concerning the origins of the civil rights movement and its significance to people at the grassroots, there have been many scholars who have argued about people's motivations for getting involved in the movement. Aldon D. Morris shows how the movement originated in religion and people's religious experiences, especially women's experiences, in his text, The Origins of the Civil Rights Movement: Black Communities Organizing for Change. ${ }^{21}$ In Witnessing \& Testifying, Rosetta E. Ross also establishes women's religious experiences as the

19 Adam Fairclough, To Redeem the Soul of America: The Southern Christian Leadership Conference and Martin Luther King, Jr. (Athens: University of Georgia Press, 1987), 4.

20 Branch, Parting, 264; Branch, Pillar, 70-71; Thomas and Franklin, Sisters in the Struggle, 117; Charles Marsh, The Beloved Community: How Faith Shapes Social Justice, from the Civil Rights Movement to Today (New York: Basic Books, 2005), 88; and Marsh, God's Long Summer, 31.

21 Aldon D. Morris, The Origins of the Civil Rights Movement: Black Communities Organizing for Change (New York: The Free Press, 1984) 147-157 
origins of the civil rights movement. ${ }^{22}$ Morris traces how women leaders impacted the shaping of the civil rights movement, while Ross insists that women's religious experiences were prior to other motivations for this movement. Marcia Y. Riggs, in Can I Get a Witness?: Prophetic Religious Voices of African American Women: An Anthology, discusses how women's religious beliefs gave strong direction to the civil rights movement. ${ }^{23}$ In a recent book on this topic, At the Dark End of the Street: Black Women, Rape, and Resistance-A New History of the Civil Rights Movement from Rosa Parks to the Rise of Black Power, published in 2010, Danielle L. McGuire maintains that black women's and men's strong resistance against the sexual abuses of white racists was the origin of the civil rights movement. ${ }^{24}$ McGuire discovered that Rosa Parks was sent to Montgomery as an investigator by the NAACP. Parks was responsible for investigating the rape of Recy Taylor, who was sexually abused by local white racists, and she helped Taylor about ten years before the Montgomery Bus Boycott. McGuire reveals that Parks's work involved helping homegrown leaders form the Montgomery Improvement Association. She also highlights that the motivation for the voting rights movements in Selma was to engage in resistance against white terrorists' sexual violence. In his introduction to King's "All Labor Has Dignity" and in Going Down Jericho Road: The Memphis Strike, Martin Luther King's Last Campaign, Michael K. Honey claims that, as early as the Montgomery Bus Boycott, King was familiar with the grassroots movement that was engaged in labor unions. ${ }^{25}$

\footnotetext{
22 Ross, Witnessing \& Testifying, 51.

23 Marcia Y. Riggs, ed., Can I Get a Witness? Prophetic Religious Voices of African American Women: An Anthology (Maryknoll: Orbis Books, 1997), 161.

24 Danielle L. McGuire, At the Dark End of the Street: Black Women, Rape, and Resistance-A New History of the Civil Rights Movement from Rosa Parks to the Rise of Black Power (New York: Vintage Books, 2010), 141.

25 Martin Luther King, Jr., “All Labor Has Dignity”, ed. Michael K. Honey (Boston: Beacon Press, 2011), 14; and Michael K. Honey, Going Down Jericho Road: The Memphis Strike, Martin Luther King's Last Campaign (New York: W. W. Norton, 2008), 26.
} 
In contrast to the conclusions of Morris, Ross, and Riggs, who have analyzed the origins and motivations for the civil rights movement and concluded they were based in women's religious awakenings to human dignity, I discuss Christian women's contributions to shaping the grassroots leadership of the civil rights movement as not only based on individual religious experiences but also on black church denominational experiences. Moreover, I argue that the Christian convictions of the civil rights leaders impacted the unity or schism of civil rights organizations. I investigate how the different religious beliefs of the civil rights leaders were able to be united under the philosophy of self-reliance from grassroots movements through nonviolent tactics and shared African American church traditions. Furthermore, through researching the Citizenship School and Christian charity movements, I examine how the religious experiences of the women who changed the civil rights movement into a bottom-up movement from the grass roots were applied to the civil rights movement. In contrast to McGuire's hypothesis that working against sexual violence might have been one of the originating motivations leading to the civil rights movement, I focus on the deeper indignation of black people against the holistic injustice of Jim Crow laws as the major origin of the civil rights movement. Concerning Honey's viewpoint about King's early vision of the grassroots movements, I examine other reasons why King could not develop the specific tactics for the grassroots people during the early years of SCLC. I also examine why the leaders of the civil rights movement were able to quickly expand the movement from their local concerns to a nationwide vision of social justice after 1961. In my dissertation, I show that women's religious experiences can provide a broader explanation of how the origins and motivations of this movement were shaped than other reasons can. 


\section{Contributions of this Dissertation}

This dissertation provides a new historical perspective of how Christian women civil rights leaders were major forces shaping the civil rights movement more so than has been recognized before. Through analyzing the documents and records of the civil rights movement, I intend to highlight pivotal black women leaders' impacts on building one of the most important scenes in the civil rights movement for voting rights. According to the aforementioned academic research, Septima Clark and Ella Baker were the initiators who reminded the major civil rights leaders of SCLC and SNCC of the importance of local civil rights programs at the grassroots level. ${ }^{26}$ However, I insist that Clark's Citizenship School and Robinson and Baker's strategies for organizing local people impacted not only the early stage of the voting rights movement, but also the tremendous shift in the current of the civil rights movement, by establishing a new paradigm of grassroots movements that could mobilize for national social justice. Through examining the original records and works of major civil rights leaders such as Baker, Clark, Parks, Robinson, Nash, Hamer, King, Young, Cotton, and Lewis, I demonstrate how women leaders continuously influenced the central stream of the civil rights movement after SCLC and SNCC began engaging in social actions for voting rights.

The historical importance of the women leaders of the civil rights movement has been minimized because it was overshadowed by the popularity of the male leaders of the movement. Moreover, the way in which women's religious convictions regarding human dignity were able to unify diverse civil rights organizations around the common goal of self-reliance through nonviolent movements has been ignored. Septima Clark and Bernice Robinson have not been

26 See Morris, The Origins of the Civil Rights Movement, 155-157; and Ross, Witnessing \& Testifying, 44-46. 
understood as the leaders who introduced the major civil rights leaders to the broader tactics that decreased tensions among the proponents of the various tactics of nonviolent direct actions, local people's rights, and radical changes through self-defensive violence. I demonstrate how Clark and Robinson introduced the religious supporting beam of the grassroots movement to Andrew Young, Dorothy Cotton, James Bevel, Hosea Williams, Bob Moses, James Forman, and Diane Nash and then how these young key leaders of SCLC and SNCC developed this conviction into a new wave that enabled the major civil rights leaders to be unified for voting rights.

Concerning the direct actions of local organizations at the grassroots level, I demonstrate that Cotton and Young of SCLC's CEP and Nash and Moses of SNCC were the civil rights leaders who encouraged diverse local organizations to be unified for voting rights. The connection between Clark's Citizenship School and these young leaders of SCLC and SNCC have been ignored in academic studies so far. Based on the Christian belief in God's providence for the beloved community, Clark and Nash successfully united local organizations into voting rights movements at the grassroots level. Women leaders connected their religious experiences to the grassroots movements, and their religious convictions created the main force for building the civil rights movement. This dissertation sheds light on the religious contexts of the laywomen leaders, who had a different philosophy and set of denominational connections to people than the clergymen leaders. Through analyzing women leaders' unique Christian freedom movements and local civil rights movements in connection with church denominations, I demonstrate how these religious movements created and led the mainstream of the civil rights movement toward gaining rights for diverse African American local groups during the voting rights movement. Through examining the religious context of the shaping of the women leaders' grassroots movements, I prove the connection between religion and these grassroots movements. This 
project redefines the real role of women leaders (who have received little attention) during the civil rights movement as creators and paradigm-shifters.

In addition, this dissertation analyzes how well-known male leaders, such as Martin Luther King, Jr., Andrew Young, and John Lewis, and the leading unions of the civil rights movement were influenced by veteran women civil rights leaders. I argue that King and SCLC changed their main policy and the directions of the movements as a result of the influence of the women leaders' grassroots movements. Thus, by demonstrating the process of SCLC's changing tactics according to the women leaders' tactics with the grassroots movements, this dissertation provides a new perspective of and historical evidence for women leaders' influence in leading King and SCLC to social movements at the grassroots. From this research, this dissertation can provide an academic source for tracing the process of the shift in the policy and leadership structure of the civil rights movement according to prominent black women's leadership, which was able to connect to local people in detail. Through proving the religion-based origins and development of the civil rights movement, there is no question as to the importance of religion in the civil rights movement. I use religion as an objective tool for analyzing these historical issues.

This dissertation also provides broader insight into the value of grassroots movements beyond the civil rights movement. By examining the social justice work of Baker, Clark, Parks, Robinson, Hamer, Cotton, and Nash, I prove that women leaders' grassroots movements enabled the civil rights movement to create long-lasting visions of human rights that have encouraged communities nationwide to struggle for human rights. Just as Gordon Keith Mantler suggests that the debates on the success or failure of the Poor People's Campaign of SCLC fail to explain how this movement impacted poor people and societies, this thesis does not evaluate whose 
leadership was most successful. ${ }^{27}$ Rather, I will pursue which tactics of the civil rights leaders introduced people not only to the long-lasting goals of social justice, but also to the higher vision of uplifting grassroots movements as a force for change in communities nationwide.

Outline of the Dissertation

Chapter one analyzes the debates regarding the leadership of the civil rights movement because this issue has raised questions about the efficacy of the mass movements that were not started by but were helped by SCLC. I research how SCLC initiated its efforts and what kind of problems the initial SCLC had after the Montgomery Bus Boycott. Furthermore, I analyze the financial status of SCLC and its leadership structure.

SCLC tried to advise and help local unions organize their civil rights movements to work with SCLC's mass movement, the Crusade for Citizenship, which started in 1957. In this chapter, I describe various analyses of this leadership issue from 1957 to 1960, the years when SCLC was expanding to major Southern cities. I discuss why SCLC faced financial and leadership problems that blocked King's ambitions for Southern cities and that weakened their goal of expanding their local social movements to the national level. I discuss the origins of this leadership issue, which caused the quagmire of the civil rights movement. I analyze why SCLC clerical leaders had to run about in confusion, without setting clear goals and gaining the support of local people and the mass media, unlike their experience with their previous movement, the Montgomery Bus Boycott. Thus, it is meaningful to investigate further reasons for their distracted leadership and the lack of gains from the mass movements between 1957 and 1961.

${ }^{27}$ Gordon Keith Mantler, "Black, Brown, and Poor: Martin Luther King, Jr., the Poor People's Campaign and Its Legacies" (PhD diss., Duke University, 2008), 11. 
This chapter also analyzes the process by which SCLC's problems with expanding the voting rights movement were solved by adoption of the Highlander Folk School's Citizenship School at the recommendation of the women civil rights leaders. I introduce why King and SCLC adopted Septima Clark's Citizenship School, even though there were suggestions from some local voting rights programs that King adopt their programs.

In chapter two, I investigate the historical backgrounds of King and SCLC that led to their adoption of the Highlander Folk School's Citizenship School program. Moreover, I analyze the circumstances that caused the Highlander Folk School to transfer the Citizenship School to SCLC. This chapter explains how women leaders of the Citizenship School developed their grassroots tactics and influenced the civil rights organizations to change their top-down leadership models to bottom-up leadership, which enabled their movements to work closely with local underprivileged people. This investigation provides the key to understanding how the grassroots tactics of the Citizenship School were able to produce multiple grassroots leaders, such as Fannie Lou Hamer, Diane Nash, and Annell Ponder of the voting rights movement, in contrast to elite, hierarchical leaders such as King. I analyze in detail the programs and tactics of the Citizenship School and the CEP of SCLC for explaining how the Citizenship School awakened local underprivileged people to lead the voting rights movement as subjects of the movement due to self-awareness. This chapter reveals the crucial elements that led the women leaders' Citizenship School program to create the dynamics that caused the civil rights organizations to be unified and to achieve the goal of equal voting rights. To explain the process by which the citizenship education programs were adopted and developed by the major civil rights organizations, this chapter provides the narratives of the grassroots leaders' voting right efforts. 
Chapter three argues that the religious backgrounds and denominational traditions of the Christian women civil rights leaders impacted the development of their civil rights activities. I highlight how their religious backgrounds created their diverse motivations for dedicating their lives to helping and developing local black people in the South who were suffering from poverty-stricken circumstances. There were diverse denominational traditions that impacted the formation of the Christian thinking of the women leaders for pursuing the beloved community, racial rights, freedom, self-determination, gender rights, and human rights. This chapter investigates the diverse denominational experiences of the women leaders that created the dynamics to empower grassroots people and that contributed to the development of the civil rights movement by providing the bottom-up leadership of the laypeople as an alternative to the top-down leadership of the male clergy.

This chapter also explains the historical understandings of the women leaders, who recognized their civil rights movements as products of the freedom movements of the black church from the slavery era. I investigate how the Christian women civil rights leaders succeeded by drawing upon the self-awareness and determined spirit of the women leaders who had fought for freedom and social justice beginning with the slavery era, such as Sojourner Truth and Harriet Tubman. I examine how the Christian women civil rights leaders taught grassroots people about the freedom fighters who dedicated their lives to social justice as they practiced biblical truths for pursuing social justice. Moreover, this chapter analyzes how the different religious experiences of these women civil rights leaders impacted the production of a grassroots leadership that created different forms of power for civil rights from those of the male clerical leadership. 
In chapter four I demonstrate that women civil rights leaders influenced the leaders of major civil rights organizations, such as SCLC, SNCC, CORE, the NAACP, and the Council of the Federated Organizations (COFO), to lead the successful voting rights movements in Birmingham, Mississippi, St. Augustine, and Selma by adopting the grassroots tactics of the Citizenship School. This chapter analyzes the impact of the women leaders' Citizenship School by producing multiple young civil rights leaders who created alternative leadership for the civil rights movement, such as Andrew Young, James Bevel, Bob Moses, Fannie Lou Hamer, Dorothy Cotton, Diane Nash, Hosea Williams, James Forman, and John Lewis. These young people led the voting rights movement from 1961 to 1965 as a grassroots movement, under the supervision of the women leaders. These new leaders of the major civil rights organizations inaugurated a new era of the civil rights movement through developing the grassroots leadership of the trainees of the women leaders' Citizenship School. The women grassroots leaders who produced the young leaders demonstrated their horizontal leadership style, which differed from the hierarchical leadership model that adhered to elite leaders without producing succeeding leaders of young people. I demonstrate the victorious results of the women leaders' grassroots leadership through the successes of the young leaders' voting rights efforts.

This chapter also evidences how the women leaders' Citizenship School influenced resistance against the brutal violence of white racists, and how it led grassroots civil rights leaders to fight for human rights until they faced death threats and even death by holding onto a strong faith in nonviolent resistance. The murders of Medgar Evers, the three CORE activists of the Mississippi Summer Project, Jimmie Lee Jackson, and the four teenage girls in the 16th Street Baptist Church bombing signify martyrdom as a means for remedying the social sickness of American society and signify 
the unquenchable hope for social justice of the grassroots people. This chapter analyzes how the women leaders' grassroots tactics enabled the civil rights movement to expose social evil and to awaken people nationally to fight nonviolently against dehumanizing violence as the grassroots people were armed by the determined spirit. I examine how the women leaders expanded their tactics to achieve the desegregation of voting rights and the creation of beloved community through training the civil rights activists of the major organizations. 


\section{Chapter One}

\section{Origins and Debates about the Leadership of the Voting Rights Drive by the Southern Christian Leadership Conference from 1957 to 1960}

This chapter analyzes the circumstances that led to the Southern Christian Leadership Conference (SCLC) adopting the grassroots tactics of the Citizenship School of the Highlander Folk School (HFS) in order to reform its routine tactics and leadership problems. This transition meant that SCLC's hierarchical clergy leadership strengthened the leadership of lay people in their own communities. The establishment of SCLC revealed that its major goal was to gain voting rights for African Americans, who had suffered due to their secondclass citizenship. This goal required grassroots tactics because its success depended on realizing the value of individual voting rights for each segregated, second-class citizen. King and SCLC leaders, who were mostly male pastors and mass-movement leaders, came to experience the gap between the goal of desegregating voting rights and the realistic tactics needed for achieving that goal. This dilemma exposed the needs for alternative leadership and tactics for Southern-wide success.

The Montgomery Bus Boycott was the first civil rights movement of King and the Montgomery Improvement Association (MIA). After 381 days, the boycott proved successful when the United States Supreme Court declared Alabama state laws requiring segregated public transportation were unconstitutional. Following the success of the Montgomery Bus Boycott, King and the other leaders of the MIA were encouraged by pastors and civil rights leaders in the South to build a social association that could organize civil disobedience actions against segregation in areas beyond Montgomery. Toward the end of December 1956, King met his veteran civil rights friends Ella Baker, Bayard Rustin, and Stanley D. Levison (Levison had fundraised for the southern civil rights movements as a member of In Friendship in New York, which had Baker as one of its leaders). During their meeting, Baker 
shared with King her idea of establishing a Southern-wide organization that would expand the MIA's movement through voter registration drives, an idea she had already discussed with Rustin. ${ }^{28}$ King invited about sixty pastors to join an organizational meeting, which was called the Negro Leaders Conference on Nonviolent Integration, at Ebenezer Baptist Church in Atlanta in January 1957. During this meeting, the pastors voted to establish the Southern Negro Leaders Conference on Transportation and Nonviolent Integration, whose name was later changed to Southern Leaders Conference, and finally to Southern Christian Leadership Conference; King was elected president of this institution. ${ }^{29}$

As a result of his discussion with Rustin and Baker, King determined that the major work of SCLC would be to promote the Southern-wide movements that targeted increased voter registration of African Americans. Many historians, such as David Garrow and Aldon Morris, argue that King just adopted the voting rights plans of Rustin and Baker, and they skip on to describe how King also had the idea of and previous experience with voter registration efforts. ${ }^{30}$ For instance, in his Bearing the Cross, Garrow describes the initial stage of SCLC's voter registration drives: "Rustin's agenda had a wide sweep . . . Rustin explained, there would be two principal methods to employ: voting power and mass direct action." 31 In his The Origins of the Civil Rights Movement, Morris explains that the beginning of SCLC's voter registration drives was based on the "seven working papers" which were written in advance of the first meeting of SCLC by Bayard Rustin. ${ }^{32}$ However, before and during the Montgomery movement, King had already been working with this idea that the civil rights movement had to have as its priority the desegregation of voter

28 Garrow, Bearing the Cross, 84.

${ }^{29}$ Martin Luther King, Jr., The Papers of Martin Luther King, Jr., vol. 4, eds. Clayborne Carson et al. (Berkeley: University of California Press, 2000), 39-46.

${ }^{30}$ Garrow, Bearing the Cross, 84; and Morris, The Origins of the Civil Rights Movement, 102.

31 Garrow, Bearing the Cross, 85.

${ }^{32}$ Morris, The Origins of the Civil Rights Movement, 84. 
registration. In his Stride Toward Freedom, recalling the next step of the Montgomery Bus Boycott at the end of 1956, King designed "a ten-point program" for the future work of the MIA. He titled this program "Looking Forward"; it focused on improving education, health, economic status, and law enforcement. ${ }^{33}$ Out of all these efforts, King emphasized that promoting voter registration of all African Americans was a prerequisite for achieving the goals of the program. King's assessment was that the end of segregation depended on solving the problem of "economic deprivation" through the Looking Forward program, which must have a social campaign to promote black voting registration. ${ }^{34}$

Even before the Montgomery movement, King's emphasis on the voting rights of African Americans was evident in his plans for Dexter Avenue Baptist Church titled "Recommendations to the Dexter Avenue Baptist Church for the Fiscal Year 1954-1955." In these plans he stated, "Every member of Dexter must be a registered voter." 35 In an article in Birmingham World dated January 25, 1955, the reporter summarizes King's speech at a National Association for the Advancement of Colored People (NAACP) rally: "Among the ways the group can help itself toward the goals of first-class citizenship he said was by getting the ballot. A voteless people is a powerless people." 36 Cooperating with voter registration efforts and becoming a member of the NAACP were two major focuses of King's ministry and goals for the members of the Dexter Avenue Baptist Church before the Montgomery Bus Boycott. In order to realize this priority, King organized a "Social and Political Action Committee" in the Dexter church, and Jo Ann Robinson and Rufus Lewis, who were key figures in the Montgomery Bus Boycott, were active members of the

\footnotetext{
${ }^{33}$ Martin Luther King, Jr., Stride Toward Freedom: The Montgomery Story (Boston: Beacon Press, 2010), 181.

34 Ibid., 218.

35 Martin Luther King, Jr., The Papers of Martin Luther King, Jr., vol. 2, eds. Clayborne Carson et al. (Berkeley: University of California Press 1994), 290.

36 Ibid., 330-331.
} 
committee. ${ }^{37}$ Thus, the recommendation of Baker, Rustin and Levison to establish SCLC for the promotion of Southern-wide voter registration drives was in line with King's vision for the civil rights movement after the Montgomery protest.

Since SCLC was founded on the need to ensure black voting rights, the most crucial ability of King and other SCLC staff members was their skill for organizing successful campaigns and movements to increase the numbers of African American voters. To increase the number of new black voters up to two million before the presidential election of 1960 , SCLC inaugurated two programs to promote voter registration and hired staff members who were professionally trained for local movements. First, King and SCLC leaders organized the Prayer Pilgrimage for Freedom in Washington, D.C., on May 17, 1957. There were about 15,000 to 27,000 people at the Lincoln Memorial, and King delivered a speech, "Give Us the Ballot," that Rustin had advised should highlight the economic uplift of African Americans through struggling for their voting rights. The Prayer Pilgrimage was a mass movement like the one King and the MIA had organized in Montgomery. In August 1957, King proposed another program, the Crusade for Citizenship, which was a plan for a Southern-wide effort to

37 Martin Luther King, Jr., The Papers of Martin Luther King, Jr., vol. 6, eds. Clayborne Carson et al. (Berkeley: University of California Press, 2007), 19; and King, The Autobiography, 47-48. 
focus on clinics and education for voter registration. ${ }^{38}$ It was also suggested by Rustin and Levison, and it was named after Billy Graham's spiritual revivals, which were called "crusades." 39

In terms of hiring an executive coordinator for the Crusade, King urgently needed Rustin, who had a nationwide connection with civil rights leaders and organizing skills for this program. However, Levison and Rustin thought King's offer would have a negative effect on the program because of Rustin's homosexuality and record as an ex-communist, which could raise a ruckus in the South. Instead of Rustin, they strongly recommended Ella Baker, who had about thirty years' experience with civil rights movements through the Workers Education Project, the NAACP, and In Friendship, and she had been able to create successful tactics. ${ }^{40}$ Baker asked her social activist colleague Rev. John L. Tilley, who had organized the victorious voter registration drive in Baltimore as a chair of the NAACP Register and Vote Campaign a few years earlier, to join SCLC's Crusade. In April 1958, SCLC executive board agreed to hire Tilley as an executive director and Baker as an

38 There is confusion regarding the date the Crusade for Citizenship was proposed and the date it kicked off. In his autobiography, King clarifies that SCLC made plans for the Crusade for Citizenship in the summer of 1957. See King, Autobiography of Martin Luther King, Jr., 109. However, based on SCLC documents, many historians have recorded its activation date as being February 12, 1958, when Ella Baker began to initiate this program as one of its directors and mass meetings were held in key Southern states. See Fairclough, To Redeem the Soul of America, 48; Donald T. Phillips, Martin Luther King, Jr. on Leadership: Inspiration and Wisdom for Challenging Times (New York: Business Plus, 1998), 55; and Garrow, Bearing the Cross, 102. In addition, there is King's letter to Congressman Charles C. Diggs, Jr., dated December 18, 1957, which states, "In January we are initiating the Crusade for Citizenship," KPBU 108:2. Baker's delay in moving from New York to Atlanta caused the time gap between the decision of SCLC to start the Crusade program and its kick-off. King might have counted Baker's first month of working for SCLC as the initiating month of the Crusade program, and the activation date of the program was formally recorded by SCLC when Baker activated the program upon SCLC's public notice about it.

39 Garrow, Bearing the Cross, 97.

40 Baker also had been selected because she knew the South better than Rustin or any others. See "Oral History Interview with Ella Baker, September 4, 1974," by Eugene Walker, Interview G-0007 in the Southern Oral History Program Collection (\#4007), Southern Historical Collection, Wilson Library, University of North Carolina at Chapel Hill, http://docsouth.unc.edu/sohp/G-0007/excerpts/excerpt_8078.html. 
associate director of the Crusade. Fifteen months following the beginning of SCLC, Baker and Tilley were the first substantial staff leaders of SCLC's major activity, the Crusade for Citizenship.

\section{Problems of the Initial Voter Registration Programs of SCLC}

The problems of SCLC leadership and its tactics in its initial stage, which was from 1957 to the early 1960s, led King and the other leaders to adopt the grassroots tactics of the HFS's citizenship education programs. SCLC's initial programs to encourage voter registration, the Prayer Pilgrimage and the Crusade for Citizenship, had been ineffective. Even though King and other leaders of SCLC had enthusiasm for desegregating voter rights, they found themselves in a quagmire in terms of setting up effective movements in the South. There were several problems during the initial stage of SCLC. King and SCLC leaders experienced some rough going because they could not find funding sources for voter registration drives. Without adequate funding, SCLC could not hire directors and staffs who had the professional skills to set up local voter registration movements. Moreover, King and SCLC had no experience with activating voter registration drives at a Southern-wide level, which needed detail-oriented and professional skills for helping local people. There had been some local organizations that had specialized in voter registration drives beginning in the middle of the 1950s, such as the NAACP, the Southern Regional Council (SRC), and Jesse Hill, Jr.'s All-Citizens Registration Committee (ACRC) in Atlanta. King and SCLC leaders had had difficulty finding a way to set up their own program that was clearly distinct from the programs of the NAACP, the SRC, and the ACRC.

SCLC was an affiliation of social organizations in the South without individual memberships, on which the NAACP was based. However, SCLC solicited individual contributions regardless of membership. Each affiliate organization of SCLC was required to pay an annual group membership at least $\$ 25$. In the beginning of SCLC, there was an 
executive board that represented eleven states. SCLC geographically covered Alabama, Georgia, Arkansas, Kentucky, Louisiana, North and South Carolina, Maryland, Mississippi, Missouri, Virginia, West Virginia, Texas, Florida, Oklahoma, and Tennessee. ${ }^{41}$ Due to SCLC's affiliate system, the executive board members, who belonged to local organizations, could not come together to set up a centralized headquarters in Atlanta. King was frequently out of town, and Ralph Abernathy, the treasurer of SCLC, was busy with his responsibilities as the senior pastor of the First Baptist Church in Montgomery. ${ }^{42}$

Despite SCLC's state of unpreparedness, Ella Baker was recommended by Rustin and Levison to be its first director. As a veteran civil rights activist who was used to working with such organizations in the North, Baker had strong connections and sponsors. Even though Baker was a single woman who did not need to support a family, and she was supported by civil rights associations in New York, leaving her well-trodden fields in the Northern cities was a sacrificial career move. Without an office, telephone, or guaranteed wage, Baker began working for SCLC in January $1958 .{ }^{43}$ She had to stay in the Savoy Hotel near the Ebenezer Baptist Church and use the church's mimeograph machine after its office hours. ${ }^{44}$ Baker's experience of the initial circumstances of SCLC demonstrates how the early programs and headquarters of SCLC were too crude to realize a Southern-wide impact.

$\underline{\text { Financial Problems }}$

For maintaining and administering the initial programs of SCLC, King hired staff members and did fund-raising to pay for the activities of SCLC as well as the salaries of the new staff members. At the meeting of SCLC in August 1957, King proposed $\$ 200,000$ for the budget of the Crusade for Citizenship; however, SCLC members were unable to find

41 The SCLC, The Crusader, vol. 1, no. 2, November 1959, KPKC, 122:19.

42 Taylor Branch, Parting the Waters, 237.

43 Joanne Grant, Ella Baker: Freedom Bound (New York: John Wiley and Sons, 1998), 105.

${ }^{44}$ Ibid. 
sponsors who could contribute enough to make that budget amount. There were organizations such as the Packinghouse Workers and the NAACP that could help fund SCLC's voter registration drives, but their contributions hardly met King's ambitions to support Southernwide movements. There is a record showing that King visited Chicago to receive $\$ 11,000$ from the Packinghouse Workers in October $1957 .{ }^{45}$ The first year SCLC's annual income exceeded \$200,000 was the fiscal year from September 1962 to August 1963, when it reached $\$ 735,534.02 .^{46}$

The newborn SCLC, which could not claim any particular achievements and did not have detailed plans for programs, was unable to make itself appealing enough to be financed by civil rights organizations or individuals. Moreover, from 1957 to 1960, SCLC's ways of fund-raising depended on random sources, not on regular sources that could provide monthly or annual support. Wyatt Tee Walker, a board member from 1958 to 1960 and director of SCLC from 1960 to 1964, insisted in his "Report of the Director to the Executive Board," dated October 11, 1960, that SCLC needed to change its fund-raising methods. ${ }^{47}$ The previous system of depending on local communities, appeal letters, and individual donations was not enough. In the report, he demonstrated the limitations of these past fund-raising approaches and encouraged the state affiliates of SCLC to draw from the public office to aid their programs, as the Nashville board members of SCLC had done.

From 1957 to 1960, SCLC's fund-raising efforts brought in around $\$ 50,000$ annually. ${ }^{48}$ According to Morris's analysis in The Origins of the Civil Rights Movement, only 35 percent of this budget was spent on programs, while 65 percent was used for the

\footnotetext{
45 King to Rev. Davis, October 8, 1957, KPBU, 108:1.

46 SCLC, "SCLC Annual Report 1962-1963," KPKC, 57:17.

47 Wyatt Tee Walker, "Report of the Director to the Executive Board," October 11, 1960, http://www.crmvet.org/docs/6010_sclc_wyatt_report.pdf.

48 Morris, The Origins of the Civil Rights Movement, 117.
} 
maintenance of the office and salaries. ${ }^{49}$ Morris found that the amount organizations contributed to SCLC was much more than what individuals did, and funding from outside the South surpassed that of Southern churches and organizations. ${ }^{50}$ The first year that SCLC's annual income exceeded $\$ 50,000$ was the fiscal year $1959-1960 .^{51}$ These records of SCLC's income demonstrate that its Southern-wide programs stagnated during its early years as a result of not finding stable income sources to develop its programs Southern-wide.

The largest source of SCLC's income came from responses to King's appeal letters to individuals and organizations. This source of income was unreliable, however; only about 5 percent of recipients responded to these letters. When fund-raising efforts were reduced a few months at the beginning of 1959, SCLC quickly faced a financial crisis, because of their lack of regular funding sources. The Administrative Committee of SCLC cut off the budget for the staff and asked Tilley to resign from his position as executive director in April 1959. ${ }^{52}$ As Walker pointed out in his report, depending on an irregular income source had caused SCLC to weaken its staff and ongoing programs.

From 1959 to 1965, the largest source of SCLC's income was checks in response to appeal letters. ${ }^{53}$ From December 1959 to September 1960, SCLC's income from appeal letters was $\$ 26,553.96$, which was 58 percent of their total income of $\$ 45,789.70 .{ }^{54}$ From November 1960 to April 1961, income from appeal letters was \$30,980.32, while crusades and freedom rallies brought in only $\$ 7,434.96$ of the total income of $\$ 62,611.98$. During

49 Ibid.

50 Ibid., 117-118.

51 Wyatt Tee Walker, "Financial Report-Annual Meeting," Oct. 1960, KPKC, 57:9.

52 King, The Papers of Martin Luther King, Jr., vol. 5, eds. Clayborne Carson et al. (Berkeley: University of California Press 2005), 177-179.

53 According to archival records, SCLC did not keep exact periodic income reports. For these different periodic sources, I include a chart that analyzes the increase in SCLC's income from 1959 to 1965 in Appendix A.

54 SCLC, "Financial Report-Annual Meeting," KPKC, 57:9. 
these six months, SCLC spent $\$ 3,422.78$ on postage and supplies. ${ }^{55}$ For the fiscal year ending August 1961, income from appeal letters was $\$ 116,406.17$, while rallies brought in $\$ 32,787.16$, and total income was $\$ 150,903.68 .^{56}$ From September 1961 to August 1962 , income from appeal letters was $\$ 61,906.51$, income from rallies was $\$ 48,893.77$, and total income was $\$ 186,040.38 .{ }^{57}$ From September 1962 to August 1963, appeal letters raised $\$ 231,650.10$, while the money that came in from freedom rallies was $\$ 223,116.73$, and total income was $\$ 735,534.02 .^{58}$ From September 1963 to August 1964, appeal letters brought in $\$ 204,807.36$, general contributions totaled $\$ 202,889.20$, and overall income was $\$ 626,758.72$. For the six-month period from September 1964 to February 1965, appeal letters brought in $\$ 204,066.24$; general contributions, $\$ 56,775.98$; and freedom rallies, $\$ 8,535.85$; the total income was $\$ 315,738.38 .^{59}$ These records show that SCLC's annual income doubly increased in 1961 and almost quadrupled from 1962 to 1963 . While income from appeal letters fluctuated during these years, money brought in from rallies increased more than could have been predicted between 1961 and 1963.

The sudden rise of SCLC's income between 1961 and 1963 was due to the nationwide appeal of sit-ins, the activism of the Freedom Rides in 1961, the Albany Movement from 1961 to 1962, the Birmingham campaign in 1963, and the March on Washington in 1963. Therefore, SCLC's income was not directly connected to an increase in people's attraction to the cause of voting rights or to stable income sources. ${ }^{60}$ SCLC had faced a financial crisis in its initial stages because of its fluctuating income, so King and SCLC had to find a regular income source, such as the public office's support. Thus, SCLC's Citizenship Education

\footnotetext{
55 SCLC, "Financial Report Spt. 1960-Aug. 1961," KPKC, 57:10.

56 SCLC, “Auditor's Report Sept. 1961," KPKC, 57:13.

57 SCLC, "Financial Report Sept. 1961-Aug. 1962," KPKC, 57:15.

58 SCLC, "Financial Report 1962-1963," KPKC, 57:17.

59 SCLC, "Financial Reports Sept. 1964-Aug. 1965," KPKC, 57:22.

60 Morris, The Origins of the Civil Rights Movement, 307.
} 
Program (which had adopted the HFS's program) caught the attention of King and SCLC board members because it could guarantee a stable source of funds from the Marshall Field Foundation. This program, which SCLC had launched in 1960, had been able to continuously run their Southern-wide programs thanks to the stable income and tax exemption from the Marshall Field Foundation. ${ }^{61}$ Because the Marshall Field Foundation could get a tax exemption, King and SCLC were freed from difficult tax problems.

During the initial stage of SCLC, the instability of income sources caused obstacles for hiring staff to run the voting rights programs at a Southern-wide level. As I mentioned above, the first executive director of the Crusade for Citizenship, Tilley, had leave his position after working just eleven months due to lack of funding, which also caused the termination of SCLC's association of its voter registration program with Jesse Hill, Jr.'s ACRC the same year Tilley left. Miss Judith Fisher, who had been working for the voter registration drive in Baltimore and was hired to support the ACRC, SCLC's affiliate, had to leave her job in May 1959 because of the lack of SCLC funding. ${ }^{62}$ In King's correspondences with Hill during 1959, King expressed his deep apologies for ceasing SCLC's work with ACRC because of money problems. In his letters to Hill in January and May 1959, King says, "May we assure you, however, that this in no way diminishes our interest in the Atlanta voting drive. . . . May I add a personal word concerning the Atlanta drive. As you probably realize I have a rather selfish interest in this campaign because Atlanta is my home.... Unfortunately, some roadblocks stand in the way of our complying with your request to have Miss Fisher's service extended through June 30, 1959."63 These letters from King to Hill demonstrate King's disappointment with the budget problems of

61 Andrew Young, An Easy Burden: The Civil Rights Movement and the Transformation of America (New York: HarperCollins Publishers, 1996), 133.

62 King to Hill, May 5, 1959, KPBU, 56:1.

63 Ibid. 
SCLC that prevented the realization of his focal goal for voting rights in Atlanta through his Southern affiliate.

Supporting the case that appeal letters were unable to be a stable income source to pay the staff of SCLC, King's letter to SCLC board member Rev. A. L. Davis in 1960 demonstrates how SCLC's staff had difficulties playing a prominent role in the large-scale operations of the Crusade for Citizenship.

I am writing to ask a personal favor of you. In two weeks Wyatt Tee Walker will be moving to Atlanta to become Executive Director of our organization. He will be bringing his lovely wife and four children. ... There are two things that I would like to urgently request. First, there is a greater need for money than ever before. It would be most embarrassing to bring a man from a substantial Church and not be able to pay his salary. Beginning the first of August our payroll will double. Along with Wyatt, Mr. James Wood will be coming in to serve as full-time Director of Public Relations and Administrative Assistant. .. . You can help us tremendously by making a monthly pledge and making the first payment immediately. I hope you can see your way clear to pledge a minimum of one hundred dollars $(\$ 100)$ a year. . . A second thing that I would like to urge you to do is to give Wyatt a great sense of welcome by inviting him to preach in your community when ever possible. As you know, he is first and foremost a preacher (and a very good one). If we can keep him preaching he will not become homesick for the pulpit.

P.S. A. D., please let me hear from you immediately. Your check is urgently needed. ${ }^{64}$ In this letter, King reveals that SCLC hired its executive director, who was to be the chief staff member for the Crusade, without any guarantee of funding for the position. After King had already hired Walker and Wood, he urgently begged supporters of SCLC for donations to pay them. Copies of this appeal letter were sent to several people who did not guarantee their donations. As the first director of SCLC, Baker had faced the unprepared condition of SCLC's office, and the first executive director, Tilley, could only work part time for SCLC because he needed to do ministry in his church in Baltimore in order to earn a sufficient income. ${ }^{65}$ Succeeding Tilley and Baker, Walker was hired under similar conditions, with a

\footnotetext{
64 King to Davis, July 20, 1960, KPBU, 108:2.

${ }^{65}$ In King's letter to Jesse Hill, Jr., in 1959, King states that the major reason for the dissonant relationship between SCLC and the ACRC was Tilley's frequent absences due to his part-time status. King to Hill, January 28, 1959, KPBU, 56:1.
} 
salary that depended too much on unstable income sources for him to focus on the full-time work of the Crusade. King's request for Davis to invite Walker as a guest speaker at his church also shows that Walker had to work as a guest speaker as a side job, since his salary could not be paid properly. When the Marshall Field Foundation ensured annual contributions to the Citizenship Education Program of SCLC in 1961, this stable income source allowed Walker and other staff of SCLC to concentrate full time on their SCLC work on voter registration drives. Moreover, the large amount of the Field Foundation's contribution enabled SCLC to hire and develop local leaders to staff voter registration drives in local communities.

King's appeal letter to Davis also reveals that King had a limited number of contacts; he mostly relied on black churches for support. As a well-known pastor, King undisputedly favored asking for donations from pastors to support the movements of SCLC. For this reason, King organized SCLC's board members, who were mostly pastors, to make it look like a pastors' organization. From the beginning of SCLC, King liked to organize its board members and officers similarly to church pastors' committees. In 1958, there were fifteen male pastors among the twenty-three executive board members of SCLC, and there were eight male pastors among the ten officers of SCLC. ${ }^{66}$ When it came to hiring an executive director, King hesitated to give Baker the position because he thought it was more suitable for a male pastor to serve in this role. ${ }^{67}$ As his letter to Davis exposes, King favored his major staff members, who were able to appeal to the familiarity of church people with them and could garner their support for their pastors' organization. The stable income from the Field Foundation contributed to reforming the financial system of SCLC, which had depended on

66 SCLC, "Southern Christian Leadership Conference, INC.," KPBU, 114:2.

67 Lynne Olson, Freedom's Daughters: The Unsung Heroines of the Civil Rights Movement from 1830 to 1970 (New York: Touchstone, 2001), 139; and Branch, Parting the Waters, 247. 
churches' support in response to appeal letters. The stable income from a non-religious donor also enabled SCLC to overcome its preference for clerical leadership and to train local leaders who were laypeople.

In relation to tax payments, King and SCLC had troublesome conflicts that made it difficult to maintain the work of SCLC. When King tried to move from Montgomery to Atlanta in 1960, the Internal Revenue Service and the state of Alabama ordered King to prove he had not earned more than his declared income. King used his personal bank account to pass most donations to SCLC and the MIA, and he had problems showing what was his own income versus donations for his organizations. As a result, the tax auditor of Alabama did not allow contributions to SCLC to be nontaxable. King tried to fight this challenge, with the help of Levison, but he failed to prove the contributions were nontaxable income. King had to pay taxes, and he could not prove SCLC's income from donations were nontaxable. This incident heavily impacted the financial plans of SCLC and King's personal income. HFS's Citizenship School was a tax-exempt institution that was able to get a donation from the Marshall Field Foundation as nontaxable income. This was one of the most crucial reasons for SCLC to choose citizenship education as its major program. After this tax harassment, King had to get his salary from Ebenezer Baptist Church, not from SCLC. ${ }^{68}$ Chauncey Eskridge, who helped King win a verdict of acquittal as his attorney in this case, went on to work as SCLC's legal advisor until King's assassination in $1968 .{ }^{69}$

\section{Communication Problems}

Charles Morgan, who was on SCLC's board of directors, described it as follows: "SCLC is not an organization, it's a church." "T0 The executive board members and officers of SCLC were predominately male pastors. The pastors' leadership of SCLC caused its civil

68 Young, An Easy Burden, 282.

69 Ibid., 382; and Branch, Parting the Waters, 297.

${ }^{70}$ Fairclough, To Redeem the Soul of America, 1. 
rights activities to be both assets and liabilities. Using its Southern-wide network of ministers, SCLC benefitted greatly from the intrinsic trust church people had in ministers and the appeal the organization held because of its ministerial leadership. For external relationships with other civil rights activists, these benefits enabled SCLC to fund-raise with and experience cohesion with local organizations of black churches. However, the clericalstyle leadership of King and SCLC board members prevented it from creating effective relationships with and among staff and with affiliated organizations of SCLC during its initial stage.

The clerical leadership of SCLC created a hierarchical structure for the organization. In 1958, according to an SCLC brochure, the top officers of SCLC were the president, King; the first vice-president, Rev. C. K. Steele; the second vice-president, Rev. J. E. Lowery; the third vice-president, Rev. Samuel W. Williams; and the fourth vice-president, Rev. T. J. Jemison. ${ }^{71}$ Next in line under these vice-presidents was the secretary, Rev. F. L. Shuttlesworth; the assistant secretary, Mrs. Katie E. Whickam; the financial secretarytreasurer, Rev. Ralph D. Abernathy; the chaplain, Rev. Kelley M. Smith; and the historian, Dr. Lawrence D. Reddick. In this brochure, there were two staff members listed: Miss Ella J. Baker as the executive director (she replaced Tilley after he resigned) and Mrs. Ernestine Brown as the office secretary. ${ }^{72}$ In this structure of clerical leadership, most staff members and the civil rights activists who were affiliated with SCLC as laypeople had to follow the pastors' instructions and ask permission from them to perform various functions.

In the initial stage of SCLC, the number of executive board members and officers of SCLC demonstrate that there were many people in decision-making capacities in comparison to the mere two staff members charged with initiating its programs in the field. Except for

71 SCLC, "Southern Christian Leadership Conference, INC.," KPBU 114:2.

72 Ibid. 
King and Ralph Abernathy, the board members and officers usually took on the responsibilities of decision-making and introducing SCLC's programs to their communities, but not of participating in the office work of SCLC. ${ }^{73}$ King and SCLC had a lot of help and advice in forming this organization and in setting up campaigns for the voting rights drive from Baker, who had about thirty years of experience with the civil rights movement. ${ }^{74}$ However, another reason why they had disliked placing her in executive board meetings for making important decisions was that she was not submissive to the clerical leaders' instructions. ${ }^{75}$ Even though Baker had worked as a civil rights leader in the North, in SCLC she had to make the first drafts of most of the plans of SCLC and propose them to the board members, and she had to help the president and the vice presidents write appeal letters and send them to donors and other civil rights activists. In King's letter to Mr. Chester Bowles in the late 1950s, he explained, "Ella Baker usually proposed conferences, selling King's book, SCLC's working orders (mimeograph machine, using individual letters)." 76

During its early years, SCLC tried to be the center of local black church affiliations by order of hierarchical executive leadership in Atlanta. The first executive director of SCLC, Rev. Tilley, listed the key pastors of all Southern cities and sent them letters asking them to affiliate with SCLC and contribute funds to it. ${ }^{77}$ SCLC's board members believed that black churches could phenomenally increase voter registration if every Southern black church affiliated with them for SCLC's voter registration drive. ${ }^{78}$ Thus, the major work of the directors of SCLC during its initial years was compiling lists of black church leaders and

\footnotetext{
${ }^{73}$ Most officers and board members of SCLC were influential leaders of other preexisting organizations. For example, Jemison worked for the National Baptist Convention, and Shuttlesworth was a leader in the Alabama Christian Movement for Human Rights (ACMHR).

74 Olson, Freedom's Daughters, 139.

75 Ibid; and Garrow, Bearing the Cross, 131.

76 King to Bowles, KPBU, 107:4.

77 Morris, The Origins of the Civil Rights Movement, 109.

78 SCLC, "Public Relations Prospectus," Crusade for Citizenship, 1957, KPBU, 112:2.
} 
sending them information about its programs in order to persuade them to affiliate with them. Because of this inordinate dependence on black church leaders, two or three staff members of SCLC were kept busy contacting pastors and helping them develop comprehensive programs for laypeople. Remembering SCLC's first meeting, which made the decision to found SCLC in January 1957, Baker said, “At this meeting there were over 100 men present . . . I don’t think that there were any women there except me. There may have been one or two others. And these men were willing to do something I had never seen Negro ministers do before: they were willing to analyze each of the papers we presented."79

The excessive number of clerical leaders in SCLC caused the problem that there were too many people giving directions at the Atlanta headquarters, but few people actually initiating local programs for Crusade for Citizenship. Insufficient numbers of staff members caused problems with internal relationships between the leaders of SCLC, its staff, and its affiliated members. Tilley's ineffective work as the first executive director originated from his frequent absences. Even though Baker was better suited to work full-time as the executive director than Tilley, SCLC's clerical leadership favored hiring a male pastor, Tilley, who had to serve as a part-time director because he could not afford to quit his job as the senior pastor of his church in Baltimore. Tilley's frequent absences caused a misunderstanding with one of SCLC's affiliates, Hill's ACRC in Atlanta, in 1958. King wrote a conciliatory letter to Hill concerning this misunderstanding in January 1959:

I am in receipt of your letter of January 19, outlining the details of why your Committee found it necessary to discontinue the services of Rev. John L. Tilley as Director of the Atlanta Voting Drive. I have the contents of this letter with scrutinizing care. Naturally we were very sorry to know that Rev. Tilley's schedule made it impossible for him to give as much time as you thought was necessary in the early stages of the campaign. The Board of the SCLC was under the impression that the Atlanta All-Citizens Registration Committee was aware of Dr. Tilley's part-time status from the beginning and that he would occasionally have to be out of the city. We regret very deeply that this misunderstanding arose. ${ }^{80}$

79 Ella Baker, interview by Joanne Grant, 1966-1968, in Grant, Ella Baker, 103.

${ }^{80}$ King to Hill, January 28, 1959, KPBU, 56:1. 
Tilley's problems demonstrate that the clerical leadership's bias toward having a male pastor as the executive director created a hindrance in the proper initiation of the voting rights drive. The board members of SCLC could not hire a full-time executive director due to a lack of funds, but they had to fire Tilley after eleven months because his frequent absences caused SCLC to be ineffective with fund-raising and caused misunderstandings with its affiliates. As discussed previously, King was able to hire Baker as a full-time executive director without concerns over her salary, while hiring Tilley based on the partiality of the board members for a male pastor created double the trouble for its voting rights campaigns.

The process leading to Tilley's resignation created other predicaments for the leaders and staff of SCLC. During the committee meetings that involved a discussion about firing Tilley, board member Sam Williams blamed Tilley's incompetence for his lack of success. Lawrence Reddick, the historian of the board, in his notes described the administrative committee meetings in April 1959 as follows:

In our first days meeting Sam Williams' assault upon Tilley, I felt was too much. I feel that Americans abuse each other more than is necessary. Martin reported that a member of Tilley's church in Baltimore had taken a shot after him. I wondered how a man as mild as Tilley could make someone so angry as to shoot at him. We had list missed two pay days, each of two weeks and upon my recommendation worked out a budget covering all debts due and expected for the next two or three months and on the basis of that float alone. This I learned was done subsequently. ${ }^{81}$

As a result of the meetings, SCLC administrative committee fired Tilley and Fisher who assisted his work with the ACRC, and they had to reduce the salaries of Baker and the secretary, Ernestine Brown. ${ }^{82}$ When King notified Tilley of the administrative committee's decision through his letter on April 3, 1959, he begged Tilley not to blame SCLC and break their trust with each other. ${ }^{83}$ However, King suspected Tilley contributed to the hostile article

${ }^{81}$ Lawrence Dunbar Reddick, notes on SCLC Administrative Committee Meetings on 2 and 3 April 1959, in King, Papers of Martin Luther King, vol. 5, 177-179.

82 Ibid.

83 King to Tilley, April 3, 1959 in King, Papers of Martin Luther King, vol. 5, 180. 
on SCLC in Jet magazine in October $1959 .{ }^{84}$ The article's analysis that "the clergy-based Dixie vote campaign has almost come to a halt" arose King's indignation, and he protested against the magazine for disseminating false ideas about SCLC. ${ }^{85}$ King's public argument with Jet magazine caused damage to SCLC's peace-making image. Even though King had to relinquish this argument, the issues surrounding Tilley's work damaged the trust between SCLC's leaders, staff, and supporters.

Commenting on King's work for the Crusade in the field, Reddick described him as "a crusader in a gray flannel suit." ${ }^{\prime 86}$ He ascribed the stagnation of the Crusade for Citizenship to King's tepid dedication to this movement. In his April 1959 administrative committee notes, Reddick wrote:

Over seas when he raised the question with me I had said to him that either he must devote himself to full time to Crusading and thus give up his church and all other means of assured income and let his family and himself depend upon whatever people would do for him for his and their lively-hood. I know that he will never do this. se So M. L. K will never become a Vinoba Bhave. He will continue to be a crusader in a gray flannel suit. ${ }^{87}$

These reflections by Reddick provide a lens into how King and other clerical leaders of SCLC practiced their responsibilities for the Crusade for Citizenship. Baker frequently criticized SCLC's clerical leaders as "glory seekers" because their inclination toward being leaders, not field workers, hindered the development of local voting rights drives. ${ }^{88}$ In "Proposed Plans for Kick-off Meetings: Crusade for Citizenship" dated January 20, 1958, the following responsibilities are given to leaders for the Crusade: "One single person in each community should be given responsibility to call together a committee to insure a successful meeting in each city. . . . Leaders of the Leadership Conference should exchange cities as

\footnotetext{
${ }^{84}$ Ibid.

85 Branch, Parting the Waters, 265.

${ }^{86}$ Reddick, notes on SCLC Administrative Committee Meetings on

2 and 3 April 1959, in King, Papers of Martin Luther King, vol. 5, 177-179.

87 Ibid.

88 Olson, Freedom's Daughters, 139.
} 
drawing cards and main speakers at the 20 meetings. For example: Rev. Albernathy might go to New Orleans while Rev. Davis would go to Montgomery." 89 Even though these clear requirements were given to leaders at the beginning of the Crusade, the clerical leaders of SCLC generally ignored their responsibilities to their local communities. ${ }^{90}$ Neglecting their responsibilities, the board members and officers of SCLC focused on directing the Crusade, even though they did not have enough staff members. Thus, these leaders were criticized as "male chauvinists" and "autocratic leaders" who failed to promote the local programs of the Crusade at the grassroots level. ${ }^{91}$

As historian Thomas F. Jackson points out in his book From Civil Rights to Human Rights, King and SCLC leaders failed to grow their movements for voting rights during the early years of SCLC because they cared too much about pastoral and political authority and not enough about awakening laypeople and working at a grassroots level. ${ }^{92}$ King had focused on garnering President Eisenhower's support for the civil rights movement through Rev. L. K. Jackson, who was a senior pastor of St. Paul Baptist Church in Indiana. Through the connection with his father, Rev. Martin Luther King, Sr., King had asked Jackson several times to help SCLC leaders meet the president. In King's letter to his father dated August 7, 1958, King begged his father to introduce him and Abernathy to Jackson:

Enclosed is a copy of the recent letter that I sent to Dr. Jackson concerning a post which I think Ralph Abernathy could superbly fill. I would appreciate very much if you would write Dr. Jackson urging him to make this appointment. It would be a tremendous help for the SCLC and the whole work of civil rights throughout the nation. I believe a word from you, since you are close to Dr. Jackson, would bring affirmative results. ${ }^{93}$

Jackson introduced King to President John F. Kenney in 1963, and he asked the president to

89 SCLC, "Proposed Plans for Kick-off Meetings," KPBU, 113:1.

90 Olson, 144.

91 Ibid., 143.

92 Jackson, From Civil Rights to Human Rights, 104.

93 Martin Luther King, Jr., to Martin Luther King, Sr., August 7, 1958, KPBU, 108:2. 
protect the civil rights activists from police brutality and local mobs. ${ }^{94}$ According to the "Proposed Plans for Kick-off Meetings: Crusade for Citizenship" of January 20, 1958, the Crusade for Citizenship tried to differentiate itself from the NAACP, which mainly fought injustice through legal actions, because the Crusade focused on running clinics and workshops for voting rights. ${ }^{95}$ However, King and SCLC clerical leaders made few efforts to set up workshops and clinics. They wanted to be influential leaders who challenged politicians, prominent pastors, and presidents, thus imitating the NAACP's top-down tactics for the civil rights movements.

King's Personal Matters

King's personal affairs prevented him from concentrating on the Crusade and thus contributed to the ineffective start of SCLC's voting rights drive. For about a month in 1957, King visited Ghana and several European countries with other civil rights leaders, including Adam Clayton Powell, Ralph Bunche, and A. Philip Randolph. King also visited several Southern cities, New York, and Chicago, delivering speeches and fund-raising. In 1958, King publicized his book Stride Toward Freedom. King spent a great deal of time writing and editing this book; moreover, he had to travel to several cities to promote this book during the year. King was stabbed by Izola Ware Curry during a book-signing in a department store in Harlem, New York, in 1958. Following this incident, King had to be hospitalized for about a month. In 1959, King visited India to participate in a pilgrimage with Gandhi's movement and to meet with leaders of India, and he went to Jerusalem and Cairo. For these travels, King had to be out of the country about one and a half months. Thus, Baker had to request that King and the leaders of SCLC reject a flood of invitations and devote themselves full time to

${ }^{94}$ L. K. Jackson to President Kennedy, 1963, KPKC, http://www.thekingcenter.org/archive/document/letter-l-k-jackson-president-kennedy. 95 SCLC, "Proposed Plans for Kick-off Meetings," KPBU, 113:1. 
the Crusade. ${ }^{96}$ The time King spent promoting his memoir and visiting foreign countries as a civil rights religious leader known around the world reveals that his major focus was on providing leadership through media attention; meanwhile, SCLC movement for voting rights' drives needed work on its development in local grassroots communities.

\section{Ella Baker's Criticism of and Contributions to the Leadership of SCLC}

Historians such as Taylor Branch, David Garrow, Lynne Olson, and Rosetta Ross have described Baker's relationship with the leadership of King and SCLC board members as one of anger and radical discord. ${ }^{97}$ In Parting the Waters, Branch describes Baker's feelings about the clerical leadership of SCLC as follows: "His [Tilley's] gifts in this area had impressed SCLC selection committee, but they registered few voters and exacerbated Ella Baker's resentment of the preacher fraternity. Maddeningly to Baker, King was at once the antithesis of the preacher type and its epitome."98 In Freedom's Daughters, Olson highlights, “He [King] was often unavailable to take her [Baker's] calls. He would wave aside her advice, ideas, and suggestions."99 Baker's criticism of SCLC's leadership was legitimate, and her ideas were adopted and finally realized in the civil rights movement during the 1960s. Baker diagnosed the problems of SCLC and suggested transforming the leadership of the civil rights movement from a top-down structure to a bottom-up one. She suggested SCLC leaders adopt the grassroots tactics of the HFS. In relation to the success of the desegregation of voting rights movement in 1965, Baker made a vital contribution to this success and transformed SCLC's hierarchical leadership so that it fostered local community leaders.

\footnotetext{
96 Reddick, notes on SCLC Administrative Committee Meetings on 2 and 3 April 1959, in King, Papers of Martin Luther King, vol. 5, 177-179.

97 Branch, Parting the Waters, 247; Garrow, Bearing the Cross, 141; Olson, Freedom's Daughters, 139; and Ross, Witnessing \& Testifying, 44-45.

98 Branch, Parting, 247.

99 Olson, Freedom's Daughters, 145.
} 
After Tilley resigned as the executive director of SCLC, Baker took on that position; however, King and the board members of SCLC hired her as an interim director, not a permanent director. ${ }^{100}$ When SCLC hired the male pastor Wyatt Tee Walker to succeed Baker in 1960, Walker insisted that he took Tilley's position, not Baker's. ${ }^{101}$ King and the clerical leaders of SCLC ignored Baker's contributions to the foundation of this organization and the setting up of its major campaigns, yet Baker did not abandon her duty to develop the Southern-wide voting rights drives until they could develop the structure of these programs. Compared to the two male pastors who worked as executive directors of SCLC, Baker did not care about her salary or her position. ${ }^{102}$ She was patient with being treated as a volunteer, and she tried to establish the Southern-wide campaign for voting rights, which was her primary concern. Baker dedicated herself to the civil rights movements of SCLC far more than the clerical leaders in "gray flannel suits." A 1961 SCLC document testifies,

Miss Baker came to Atlanta in January, 1958 to set-up the office of the SCLC, and to organize a special project to launch the "Crusade for Citizenship," the organization's voter-registration drive. Her original commitment was for a period of six weeks, but she was repeatedly asked to remain with the young nonviolent movement, and has served it for two and one-half years. She is presently serving as the executive director of the SCLC, and recently, she organized and coordinated the Southwide Youth Leadership Conference on Nonviolent Resistance, held at Shaw University, April 15$17 .{ }^{103}$

According to this document, SCLC board members originally hired Baker as a director for six weeks. Even though there were reports that King and other leaders asked her to stay and set up SCLC's campaigns after the six weeks was over, it was Baker's own decision to stay with SCLC, regardless of her position among the hierarchical leadership. ${ }^{104}$

It is an undisputed fact that the clerical leadership of SCLC was ignorant of Baker's

100 Branch, Parting the Waters, 258.

101 Ibid, 285; and Morris, The Origins of the Civil Rights Movement, 115.

102 "Oral History Interview with Ella Baker."

103 SCLC, "Ella Baker," 1961, KPKC, 123:39.

104 Branch, Parting the Waters, 258. 
contributions and that Baker gave harsh criticism of the leadership during the two and a half years of her service for the organization. However, unlike Tilley's case, Baker's conflicts brought about development in SCLC, not schisms. Historians of the civil rights movement such as Garrow and Grant have used narratives of conflicts, like the one found in Reddick's 1959 notes, to describe the uncomfortable relationship between Baker and King:

She [Baker] really came to lay him [King] out and abuse him. She gave him the devil for not spending more time with the SCLC. . . . Next when she was telling King [strikeout illegible] that perhaps she spent too much time in speakng [speaking] everywhere on every subject, he protested. When I said that possibly she meant that aside from speaking to raise money for SCLC or MIA that he should reserve his time for working with SCLC, he protested with a feeling of hurt. He said that an artist shoudl [should] not be denied his means of expression. That he liked to preach and felt that he should do it. ${ }^{105}$

This telling by Reddick is too fragmental to describe the complicated relationship between Baker, King, and other SCLC leaders. Even though Baker was enraged by the disrespect of King and SCLC clerical leaders toward her as a laywoman leader, she never publicly degraded the nationwide contributions that King and SCLC made to the civil rights movement. Bob Moses, who worked with Baker for SCLC, pointed out, "There's a tension between projecting a national leader and creating local leadership. It was in that tension that I think Miss Baker wasn't able really to function within SCLC organization. If you're spending all of your energy trying to project the national leader, you have very little energy left over to actually develop a local leadership."106 Thus, Baker challenged SCLC leaders to place more attention on developing local leaders than in making King into a national leader. She wanted SCLC to change, not to collapse.

105 Reddick, notes on SCLC Administrative Committee Meetings on 2 and 3 April 1959, in King, Papers of Martin Luther King, vol. 5, 177-179. They were also used for the historical descriptions in Garrow, Bearing the Cross, 120-121; and Grant, Ella Baker, 109.

106 Bob Moses, interview by Joanne Grant in Joanne Grant, Fundi: The Story of Ella Baker, Brooklyn, NY: Icarus Films, 1981, cited in Grant, Ella Baker, 212. 
In terms of Baker's criticism of the clerical leadership, she was against pastors taking on the monolithic leadership of the civil rights movement. She found that when the majority of pastors took over leadership, they disrupted the democratic leadership of the people in civil organizations, whose decision making was essential to the movement. Baker pointed out that the majority of SCLC leadership consisted of pastors and that this leadership obscured democratic leadership. ${ }^{107}$ She highlighted that "the nature of the organization would vary with the people who were doing the thinking." 108 According to Baker, the variations in people's opinions was crucial to understanding "the virtue of utilizing the mass surge."109 She warned against decision making for the civil rights movement that involved the clerical leadership instructing people to act without discussing the matter, which was the same method they used in their churches. Thus, Baker determined that the major problem of the clerical leadership of SCLC was that they made the decisions, and their opinions were biased because of their own interests.

Baker's criticism of the chauvinistic and heroic leadership of the male pastors contributed to improving SCLC's leadership and to promoting students' associations for the civil rights movement. King had barely any civil rights colleagues who would make critical comments to his face. However, like Baker, and at the same time she was working with them, Levison warned King not to be a self-centered leader or a "star" for the civil rights movement. ${ }^{110}$ Civil rights leaders Randolph and Shuttlesworth also insisted that SCLC leadership should get down and help people through hard work, not get up and direct people through public speeches. ${ }^{111}$ Even though these criticisms were relevant to King's selfcentered leadership, Levinson and Randolph kept working with King, rather than separating

107 "Oral History Interview with Ella Baker."

108 Ibid.

109 Ibid.

110 Olson, Freedom's Daughters, 145; and Jackson, From Civil Rights to Human Rights, 104. 111 Jackson, 104; and Olson, 111. 
from him. These criticisms of the leadership of King and SCLC brought not a schism but opportunities to utilize the diverse and democratic leadership among SCLC and its affiliate organizations, such as SNCC. First of all, as Baker advised, King resigned from the Dexter Avenue Church to dedicate all his efforts to the civil rights movement of SCLC; thus, he and his family moved to Atlanta from Montgomery in $1960 .{ }^{112}$ Moreover, in 1960, there arose a new wave of the freedom struggle in which young college students resisted segregation at lunch counters through sit-ins. King and SCLC leaders were willing to support this movement and participate in it with these young people, who did not accept the control of the charismatic leadership, which was in accord with Baker's philosophy. The affiliation of SCLC with the students' sit-in movement created an essential shift in the civil rights movement that brought nationwide attention and new leadership for grassroots tactics for local communities.

Baker's primary contribution to changing the leadership system of SCLC was introducing the HFS's Citizenship School to the leaders of SCLC. After she had struggled with initiating workshops for the Crusade for Citizenship program from 1958 to 1960, Baker realized that SCLC had to focus on educating adults who were illiterate. Her realization came from her dedication to promoting the Crusade for Citizenship as only a field staff member of SCLC during its initial two and a half years. Baker had issued SCLC newsletter, The Crusader, and she had traveled to several local areas, such as Columbia, South Carolina, and Birmingham and Montgomery, Alabama, to develop local voting rights efforts and workshops. ${ }^{113}$ There were many local civil rights leaders who heard about Baker's ability to

112 King's resignation from the Dexter Church was recommended by the Future Program Committee, which was a meeting of SCLC leaders in 1960 to discuss reviving the Crusade for Citizenship. Baker was one of the first leaders of SCLC to advise King to give his fulltime devotion to SCLC. See Garrow, Bearing the Cross, 120-122.

113 Garrow, Bearing the Cross, 115, 118. 
organize social movements and also asked her to come visit them. ${ }^{114}$ As the only actual field staff member of the Crusade for Citizenship, Baker pointed out that weak local leadership and communication between SCLC headquarters and the local people were major factors in the moribund state of the Crusade. Through setting up local clinics and workshops, Baker insisted that the solution to the waning of the voting rights programs was for SCLC to develop local leaders who could respond directly to the problems of local people. ${ }^{115}$ Baker had heard about the reputation of the HFS's Citizenship School, through which sixty-year-old Septima Clark had created success in educating local people to promote voting rights drives, and she decided to go to Tennessee to explore the Highlander School's program. ${ }^{116}$

In 1959, Baker visited the HFS to examine its Citizenship School. Since 1956, Clark and Myles Horton, who was a founder of the HFS, had been inviting King to speak at their conferences and annual meetings. ${ }^{117}$ King visited the school in 1957 and delivered his speech "A Look to the Future."118 From 1957 to 1959, King and other leaders of SCLC had attended conferences of the HFS featuring influential social leaders, such as Mrs. Eleanor Roosevelt. Even though Tilley had visited the HFS in 1958, Baker was the first person from SCLC who insisted on running joint programs with HFS's Citizenship School to develop the Crusade for Citizenship. ${ }^{119}$ After she investigated the HFS's programs, Baker reported,

Because of the potential value of an adult education movement to the Negro's drive for first-class citizenship, the director has attempted to find out what is happening in this field and how it can be related to the program of SCLC. To this end, the Labor Day Weekend was spent at Highlander Folk School in Monteagle, Tennessee. A primary purpose of this trip was to meet and talk with Mrs. Septima Clark, education director there. ${ }^{120}$

114 Grant, Ella Baker, 112.

115 Ibid, 114.

116 Branch, Parting the Waters, 264.

117 Horton to King, 1956, KPBU, 112:3.

118 King, “All Labor Has Dignity”, 7.

119 In July 1958, King also sent Tilley to the HFS to attend its workshop; KPBU,

112:3. Concerning Baker's proposal to adopt the HFS's Citizenship School program, see Morris, The Origins of the Civil Rights Movement, 156.

120 Ella Baker, "Report of the Executive Director," May 16-September 29, 1959, 
Baker's research was not directly initiated by SCLC board members; however, it was not an ineffective proposal for developing SCLC's voting rights campaigns. After Baker's report, Clark and Horton continually sought to persuade King and SCLC leaders to adopt the HFS's citizenship program. SCLC finally accepted this program as the major program for the Crusade for the Citizenship in 1960.

SCLC's decision to adopt the HFS's citizenship program was also aided by Baker's introducing them to the possibility of getting financial support from the Marshall Field Foundation, as it had been supporting the HFS. The Field Foundation's support was crucial to developing SCLC's financial system, which had been struggling with tax liabilities. In her letter to King on October 11, 1959, Baker argued,

This raises again the need for developing a tax exempt "arm" of SCLC. I understand that the Marshall Field Foundation has some special interest in leadership training among religious leaders. Also, I know of a foundation that has underwritten and is underwriting several small leadership meetings. This is one of the matters on which I hope to prepare a memorandum for the meeting in Montgomery. ${ }^{121}$

Based on her exploration of the HFS, Baker determined that the Highlander's programs and financial operations could provide models for improving on the weaknesses of SCLC's leadership and financial systems. HFS's success in promoting local leadership and finding funding sources was a major reason why SCLC was willing to adopt its citizenship program, instead of one of the many other workshops for voting rights drives. ${ }^{122}$ Even though Baker left SCLC before the Field Foundation decided to support SCLC's Citizenship Education Program, she was the person who contributed the most to the adoption of the HFS's citizenship program as SCLC's major program.

KPBU, in Morris, The Origins of the Civil Rights Movement, 156.

121 Baker to King, October 15, 1959, KPBU, 107:4.

122 Before SCLC adopted the HFS's citizenship program, King received proposals for workshops for voting rights drives from Hill, the NAACP, and ministers' organizations. 
Through introducing the HFS's Citizenship School to SCLC, Baker initiated her vision to develop the leadership of women, young people, and local people at the grass roots. ${ }^{123}$ The HFS had been the headquarters for promoting the grassroots leadership of women and young people through the workshops of Horton and Clark. The philosophy of the HFS was in accord with Baker's views, and this philosophy helped to bring about the reform of the hierarchical and male chauvinistic leadership of SCLC, the NAACP, and other major civil rights organizations. When student sit-ins developed as a Southern-wide movement, beginning with the sit-in at the Woolworth's lunch counter in Greensboro, North Carolina in 1960, Baker found out that there were many sit-in students who had attended the HFS's Citizenship School. ${ }^{124}$ James Lawson, who was a field secretary of the Fellowship of Reconciliation (FOR), conducted Gandhian workshops for students in Nashville, and he led his students to participate in the workshops of the HFS's Citizenship School. ${ }^{125}$ Baker recommended that King and SCLC leaders support the students and schedule a supplemental conference with these young demonstrators. ${ }^{126}$ With Baker, King, Abernathy, Walker, and Lawson as presenters, the conference was scheduled for April 15-17 at Shaw University in Raleigh, North Carolina. During the event, there were intense discussions about whether a new association for the young people could be a civil rights organization separate from the adult associations that already existed, such as SCLC and the Congress of Racial Equality (CORE). In the end, this conference established an independent democratic leadership for a young

\footnotetext{
123 Branch, Parting the Waters, 264.

124 As Morris insists in The Origins of the Civil Rights Movement, 198, some students had already started sit-ins in North Carolina in 1957. The sit-in at the Greensboro Woolworth was the first sit-in known nationally, thanks to the media.

125 John Lewis, Walking with the Wind: A Memoir of the Movement (New York: Simon \& Schuster, 1998), 80.

126 Grant, Ella Baker, 126.
} 
people's association for civil rights that would not be dictated to by adult civil rights organizations. $^{127}$

During the Raleigh conference, Baker found out that the clerical leaders of SCLC had proposed to the students that they let SCLC support and take care of them. She disagreed with their offers to the students because she thought they were trying to oppress the spontaneous leadership of the students and manipulate them. ${ }^{128}$ In retrospect she said,

I remember in Raleigh at the time Wyatt was particularly interested in this because he was coming in as executive director and he wanted a strong arm. The unfortunate part was that there was an assumption on the part of the ministers, part of the S.C.L.C. personell [personnel] who was there, that they could leterally [literally] dictate (I use the term advisedly) to representatives from their area and control their voting. It was at that point I walked out of the meeting. There was this "meeting" of the chief executives - these were adults, not a young person was present-at which they were voicing such opinions as, "I can speak to so-and-so," and "I can talk to Dorton from Virginia," and "I can control one from Montgomery," Bernard Lee. ${ }^{129}$

Feeling resentment, Baker made a decision to leave SCLC because she could not be patient with the clerical leaders' preference for hierarchical leadership over the new wave of young people's social movements. At the end of the conference, the students decided to establish SNCC, adopting Baker's advice and Lawson's draft of a statement of purpose. ${ }^{130}$ According to John Lewis, who attended the conference, King and SCLC leaders strongly advocated that the students take part in SCLC, while Baker and Lawson counseled them, "Don't let anyone else, especially the older folks, tell you what to do. Think and act for yourselves. Hold onto your energy and your vision. Keep it pure. Keep it real."131

Walker's desire, according to Baker, to make the students' enthusiasm "a strong arm" of SCLC demonstrates the crisis of SCLC's Crusade for Citizenship and the new powerful strategy young people created for the civil rights movement through the spotlight of the

\footnotetext{
127 Ibid., 129.

128 Ibid.

129 "Oral History Interview with Ella Baker."

130 Grant, Ella Baker, 130.

131 Lewis, Walking with the Wind, 108.
} 
media. ${ }^{132}$ King and Lawson, who supported the independence of the student movement, gave their own speeches to the students at the conference; however, in resonance with Baker's criticism of the hierarchical understandings of the clerical leadership, King's idea did not appeal to the students, who wanted to fight against the social segregation they experienced at the bottom of society. Baker described King's distance from the students as follows: "As far as Dr. King was concerned, (I don't remember his speech) his speech could not possibly have had the same relevance that Lawson's did because he had not been engaged in what the students had been doing with the same degree of membership (let's call it). He was still outside."133 Even though Baker left SCLC and became a coordinator of the new organization, SNCC, she cannot be blamed for causing a schism in SCLC, because the student sit-ins did not originate from SCLC, and these two independent organizations created a synergistic impact on developing the voting rights drive at a Southern-wide level. By SCLC's adopting the HFS's citizenship program later in the Raleigh conference, a convergence zone was made possible in the voting rights movement, where the people of SCLC and SNCC could share their tactics with each other. ${ }^{134}$

Concerning the relationship between Baker and the clerical leaders of SCLC, there were not always debates and complaints between them. When Baker had made an effort to visit and set up workshops with local people, Rev. Douglass Moore, who was an executive board member of SCLC, described Baker as a leader and teacher of the ministers. In March 1958, Moore tried to set up conferences and mass meetings for several denominational ministers in Durham, North Carolina. He wrote a letter to King stating, "The plan for the conference is divided into two parts. One part will be the workshops for ministers during the

\footnotetext{
132 Ibid., 105.

133 "Oral History Interview with Ella Baker."

134 Morris, The Origins of the Civil Rights Movement, 157. See also the following pages, which describe how the two organizations cooperated with each other in initiating the tactics of the Citizenship School.
} 
day. Mr. Brooks, Mitchel, McLoan of the NAACP and Rev. Odom have been contacted for this April meeting. We have not contacted Miss Baker as yet but we hope that you will send her to be one of our leaders in teaching ministers how to organized their local churches into effective voting units." ${ }^{\prime 35}$ Through these conferences and mass meetings, Moore planned to organize 200,000 Methodists to commit to the voting rights crusade and to encourage about 700,000 African American citizens to become registered voters. ${ }^{136}$ Moore, who had participated in sit-ins in Durham, also helped Baker organize civil rights leaders to gather at the Raleigh conference in 1960. ${ }^{137}$ Moore was one of the first sit-in demonstrators and had a strong clerical movement in Durham. ${ }^{138}$ When SCLC was thinking about hiring Walker as an executive director, knowing that SCLC leaders would not hire her as a permanent executive director Baker offered the position to Walker, before King suggested it to him. ${ }^{139}$

Baker was still faithfully working at her job to promote King's book Stride Toward Freedom when she wrote to Rev. A. A. McCardell on January 14, 1960, and asked him to double-check his returned check for payment of copies of the book. ${ }^{140}$ Baker had worked continually from 1958 to 1960 to sell King's book, even as she suffered from the effects of the male chauvinistic leadership, and she had just decided to leave her position at SCLC. ${ }^{141}$ From historical descriptions, Baker's criticism of the hierarchical leadership of the male clergy in SCLC was not against the male pastors who were working for civil rights but against the pastors who were not allowing the equal authority of laypeople, women, and

135 Rev. Douglass Moore to King, March 8, 1958, KPBU, 108:2.

136 Ibid.

137 Grant, Ella Baker, 127; and Morris, The Origins of the Civil Rights Movement, 198.

138 Morris, The Origins of the Civil Rights Movement, 198.

139 Grant, Ella Baker, 122.

140 Baker to McCardell, January 14, 1960, KPBU, 16:4.

141 There are consistently letters from Baker to the buyers of King's book from 1958 to 1960 (located in Martin Luther King, Jr. Papers, Howard Gotlieb Archival Research Center at Mugar Memorial Library, Department of Special Collections, Boston University), asking them to consider promoting his book. See KPBU, 16:4. 
young people, which would reform the majority male clerical leadership. Thus, Baker's criticism of the leadership of SCLC, in which she insisted on the need to "facilitate local groups and develop potential leaders," caused the reform of the leadership system of civil rights organizations and helped to establish democratic leadership in SCLC, SNCC, and other groups. ${ }^{142}$

\section{Prior Voting Rights Workshops}

There were voting rights workshops that existed before SCLC adopted the HFS's Citizenship School in 1960. King had received proposals from some organizations before 1960 to adopt their own workshop programs for voting rights. These unchosen offers suggest that the HFS's program was particularly fitting to the situation of SCLC during 1960 and unique in promoting the Southern-wide civil rights movement. Moreover, the choice of King and SCLC leaders to adopt the HFS's workshop realized the desegregation of voting rights and brought about the dramatic success of the Selma movement for voting rights. According to correspondences between King and the workshop directors, King already knew that specific workshop programs for voting rights existed in 1957 and later, before SCLC hired Baker to initiate voting rights programs. However, King and SCLC leaders did not accept these offers to integrate these workshops into SCLC's programs before 1960, even though the Crusade for Citizenship had been lagging and Baker had strongly insisted on developing workshop programs for local people. This delay in adopting workshop programs for local people reveals a gap in the leadership's understanding of the real needs of people at the grass roots. In addition, the workshop programs previously proposed had not been better aligned with the situations of SCLC than the HFS's Citizenship School was in 1960. It clarifies why the HFS's Citizenship School was so effective in developing the Southern-wide voting rights

142 Garrow, Bearing the Cross, 120. 
movement when it is compared with other workshops that were previously suggested to SCLC.

On October 27, 1957, Rev. S. F. Daly sent a letter to King to introduce the work of the Ministers Committee for Full Citizenship (MCFC). In this letter, Daly explains the workshop programs of the group in detail and requests King's help and association with the programs. ${ }^{143}$ The MCFC was a statewide organization that had a plan to register about 100,000 new African American voters in North Carolina. Like SCLC, it was a ministerial organization whose leaders were pastors from a variety of denominations. ${ }^{144}$ In Daly's letter to King, the MCFC strongly expressed its willingness to cooperate with SCLC on the MCFC's voting rights drive in order to expand the project into a Southern-wide movement. Daly had attended SCLC's Prayer Pilgrimage, but he was unable to meet with King at the conference. Daly asked King to send him copies of SCLC's voting rights programs. King responded, "I cannot send you some literature at this time, but we have had no printing done at this time," because "we are now in the process of setting up."145 King's letter indicates that the MCFC had its own workshop programs before SCLC initiated the Crusade for Citizenship. The MCFC's workshop program was one of King's references for the voting rights workshop that SCLC had been preparing.

In Daly's letter to King, he enclosed the MCFC's workshop program, “First One-Day, State-wide Workshop," dated Wednesday, April 3, 1957. ${ }^{146}$ This workshop opened with devotions, and there were two lectures during the morning session, with one titled, "The Northampton Country Registration Cases; or, New strategies to prevent our citizens from registering and how ministers can help us." ${ }^{147}$ After these lectures, there was about fifteen

${ }^{143}$ Daly to King, October 21, 1957, KPBU, 108:1.

144 Ibid.

145 King to Daly, November 18, 1957, KPBU, 108:1.

146 Daly to King, October 21, 1957, KPBU, 108:1.

147 Ibid. 
minutes set aside for free discussion, which was similar to the HFS's Citizenship School approach. For the afternoon sessions, there were four more lectures, which covered diverse issues, such as voting rights' impact on education, business and setting up voter registration drives in churches. ${ }^{148}$ Among the documents enclosed with Daly's letter, there was "A Blue Print for Full Citizenship (Elimination of Segregation).” In this plan for promoting the citizenship of black people, there were listed other needs besides voting rights, including public education, transportation, business and home ownership, public decorum, and Christian discipleship for eliminating segregation. This list is very interesting because it preceded SCLC's Chicago Freedom Movement (1965-1967) and the Poor People's Campaign (1968).

Enclosed with Daly's letter to King, there was a "Plan of Organization" for the MCFC. In this plan, the MCFC's general objectives are described as follows: "To interest and secure the cooperation of Christian ministers of North Carolina on a state-wide nondenominational, non-partisan and non-profit basis, so that we may develop sound principles and common effective procedures for the personal guidance of the ministers and for their orderly guidance of their people in attaining full American citizenship."149 The MCFC tried to develop the leadership of pastors regardless of their denomination and to focus on promoting the full citizenship of African Americans in their local areas. The membership of the MCFC was not limited to ministers, even though the organization was basically a pastors' association. ${ }^{150}$ The MCFC's leadership training program was closer to Baker's vision for developing local leadership than SCLC's hierarchical leadership focus during its initial years. Moreover, the MCFC stressed procedures and principles for initiating its voting rights drives, thus, it was better organized for supporting voting rights movements in specific local areas

\footnotetext{
148 Ibid.

149 Ibid.

150 Ibid.
} 
than SCLC was when it struggled with organizing the headquarters of the Crusade for Citizenship. From Daly's letter, King already knew of the need to develop workshop programs for voting rights drives at a Southern-wide level in 1957.

Other examples of workshop programs that King knew about before the adoption of the HFS's Citizenship School in 1960 include Rev. Moore's voting rights movement in Durham in 1958, which asked Baker to teach the pastors how to set up local workshops; Vivian Carter Mason's workshop proposal to SCLC in 1958; Jesse Hill, Jr.'s proposal for affiliation with his ACRC in 1958; and the NAACP's "Proposed Plan for Community of County-wide Voter-registration Campaign,” adopted by the NAACP's Alabama State Coordinating Committee in 1954. ${ }^{151}$ As was cited previously, Moore's request for Baker's help was for her to teach pastors how to organize workshops for local people, and he notified King that there were already 200,000 Methodists who were participating with a voting rights movement in Durham. ${ }^{152}$

As of November 22, 1958, Vivian Carter Mason, who was the former president of the National Council of Negro Women (NCNW), was collaborating with SCLC's voting rights movement, along with Baker and Fisher. ${ }^{153}$ Mason submitted to King "Professional Correspondence" that provided Baker's blueprint of the workshops for promoting local leadership through the Crusade for Citizenship. Mason's correspondence asked King to review her proposal for "making to further the work of the SCLC." ${ }^{154}$ In this proposal, Mason highlights the emergent need to establish a year-round registration program in every

151 NAACP, "Proposed Plan for Community of County-wide Voter-registration Campaign," KPBU, 103:4.

152 See page 66.

153 Christopher M. Richardson and Ralph E. Luker, Historical Dictionary of the Civil Rights Movement, 2nd ed. (New York: Rowman \& Littlefield, 2014), 340.

154 Vivian Carter Mason, "SCLC Professional Correspondence (Experience Voter registration program in Baltimore with help from Miss. Fisher)," November 22, 1958, KPBU, 108:2. 
local community in the South. She insists in the proposal, "Have workshops on state, district and city levels for leaders and sufficient guidance and working material for leaders to set up and carry out their own program under guidance." 155 In this correspondence, Mason provides an outline for the content of workshops in local communities:

Conduct workshop

A. The vote

1. Its importance.

2. Organizing for registration campaign.

3. Techniques of carrying on campaign

4. Typical problems in the state and how they can be met.

5. Federal Civil Rights Laws, Civil Rights Commission and Assistant

Attorney General's Office and how they can be used to the best advantage.

B. Types of community action needed and how best to proceed.

C. Type and techniques for the education program necessary.

D. Philosophy and techniques of non-violent resistance. ${ }^{156}$

Mason's customized workshops for local areas were very close to Baker's proposal for the Crusade for Citizenship on January 20, 1958. ${ }^{157}$ In "Proposed Plans for Kick-off Meetings,"

Baker proposed the following:

The Crusade's aims are two-fold:

a. to educate Negroes to exercise the right to vote where they have it.

b. To set up machinery to obtain right where it in practice does not exist.

Crusade will be grass-roots movement using workshops and clinics. . . Legislation is useless without people who exercise it. ... One single person in each community should be given responsibility to call together a committee to insure a successful meeting in each city. ... Should such funds be used for the voting right drive in the local community where they were collected . . . it might be best to use these funds to help establish an ad hoc community group in these areas where none exist. ${ }^{158}$

Baker and Mason shared the common aim of helping local communities promote voting rights through running their own workshop programs. In Mason's correspondence, her idea of focusing on local leadership training echoes Baker's philosophy: "The needs and problems of

\footnotetext{
155 Ibid.

156 Ibid.

157 SCLC, "Proposed Plans for Kick-off Meetings," KPBU, 113:1.

158 Ibid. There is no author's name on the "Proposed Plans for Kick-off Meeting" document, but Baker said that she was the only person who wrote drafts for the voting rights workshops of SCLC from 1958 to 1959. See "Oral History Interview with Ella Baker."
} 
each locality can best be approached and served and the resources of the community and the S.C.L.C. can be most effectively used if such an organization is formed. The leaders in the locality are best acquainted with the local situation and persons who can be of greatest help. $" 159$

Even though Baker's proposal was approved by SCLC board members as an official statement, there is no record of how King responded to and came to accept Mason's proposal. However, in Mason's correspondence she indicates that King was hospitalized in New York and that Baker stayed there to take care of him. Thus, her position in SCLC at the time might have been to serve as a temporary replacement for Baker and an assistant to Fisher. As was mentioned above, Baker's proposal for developing local leadership was not completely implemented because of budget constraints and the hierarchical leadership of SCLC. For the same reasons, Mason's proposal was not realized, and her requests in this proposal to hire more staff members and raise Fisher's salary were rejected by firing Fisher and Tilley in 1959. ${ }^{160}$ Baker and Mason clarified the budget plans for promoting Southern churches as centers for voting right workshops by distributing appeal letters to top church leaders to support the workshops. ${ }^{161}$ However, the proposals of Baker and Mason could not be activated until the adoption of the HFS's citizenship programs resolved SCLC's struggles with their budget, leadership decisions, lack of staff members, tax liabilities, and communication with young people and women leaders.

King had received another workshop proposal from Hill's ACRC in the late 1950s. SCLC board members accepted the ACRC as an affiliate in December 1958 and promised Hill that Tilley and his assistant Fisher would associate their voting rights drive with his

159 Mason, "SCLC Professional Correspondence," November 22, 1958, KPBU, 108:2.

160 Ibid., 44. See previous note.

161 Ibid. 
organization. ${ }^{162}$ In January 1959, King sent Hill a letter explaining why Tilley had not collaborated with the ACRC's programs (because of his part-time status) and stating that Fisher would continue to serve its voting rights efforts. ${ }^{163}$ Hill had sent King a memo from an ACRC meeting in 1958 with a "Proposed Plan for Community or County-wide Voterregistration Campaign." According to the "Proposed Plan," the ACRC had been working for voting rights for African Americans in Alabama since 1946. It highlighted that "community leadership and organization participation are essential to the successful promotion of this plan."164

In Hill's memo and "Proposed Plan," there are detailed guidelines for organizing a local community to promote voting rights:

Block Workers Duties

Visit every house in your block. Find out who is registered. Get those who are not registered to register. Continue to visit until all are registered. . . . Help on transportation...

How to Organize a Precinct or Neighborhood Club for Registration

First have a planning meeting with a few key people in the neighborhood to plan a large neighborhood or precinct meeting. Elect a temporary chairman and secretary from this group.

Set a date, place and time for the large neighborhood or precinct meeting. Send a letter of invitation to the meeting to: All of the citizens in the area. All of the ministers, teachers and business and professional people living in the precinct area. ${ }^{165}$

Hill's guidelines were easier and more practical for uneducated people who could not register as voters to follow than those of Mason and the MCFC. The ACRC provided the following guidance to people for local community meetings:

What to do at the first precinct meeting

Open with prayer and song.... Have a speaker give down to earth discussion on the value of voting. ... Questions and discussion period ...

162 King, Papers of Martin Luther King, vol. 5, 114.

163 King to Hill, January 28, 1959, KPBU, 56:1.

164 Alabama State Coordinating Committee, "Proposed Plan for Community or Countywide Voter-registration Campaign," KPBU, 103:4.

165 Hill to King, April 23, 1959, KPBU, 56:1. 
Thirty questions - Georgia Registration Law

One who cannot read and write must answer 20 of these 30 questions to register. ${ }^{166}$

Opening the meeting with prayer and song, having questions and discussions, and preparing people to answer the thirty questions of the literacy exam were methods similar to those of the HFS's Citizenship School. ${ }^{167}$ For financing the ACRC's voting rights meetings, Hill recommended that committee members visit people at churches, fraternal organizations, labor organizations, colleges and schools, clubs, civic and political organizations, and business organizations, and appeal to them to take an interest in the ACRC's registration campaign. ${ }^{168}$ In his "Proposed Plan," Hill detailed how ACRC workers should prepare for meetings, including bringing index cards and setting up car pools, and he recommended that workers have a meeting once a week. ${ }^{169}$ Even though there are detailed instructions for conducting local meetings in Hill's statements, there are few references to what the committee members taught the people in terms of philosophy to help them recognize the value of voting rights. As has been discussed, SCLC failed to continue assisting the ACRC in 1959 because of its budget problems. ${ }^{170}$

King had also received a program for conducting voting rights workshops from the NAACP, a "Proposed plan for community of County-wide Voter-registration Campaign," adopted by the Alabama State Coordinating Committee, NAACP, in $1954 .{ }^{171}$ In the plan, there are similar tactics to those of the ACRC for forming groups of three or four committee members, but there are few instructions or teaching materials for the local people to guide them in promoting the value of their voting rights. SCLC did not collaborate with the

\footnotetext{
166 Ibid.

167 See the next chapter.

168 Alabama State Coordinating Committee, "Proposed Plan," KPBU, 103:4.

169 Ibid.

170 Ibid., 44.

171 Alabama State Coordinating Committee, "Proposed Plan," KPBU, 103:4.
} 
workshop programs of the NAACP because SCLC had its own rule to not be in conflict with the NAACP. Moreover, in her correspondence, Mason recommended that SCLC field workers leave the area if there were successful voting rights drives being run by the NAACP. ${ }^{172}$

Even though King had plentiful sources for developing workshops to promote the voting rights of local people beginning in 1957, he failed to adopt those tactics to expand the Crusade for Citizenship to a Southern-wide level until SCLC adopted the HFS's Citizenship School in 1960. The delay in SCLC's developing local leadership through workshop programs was not based on a lack of prior examples of local voting rights movements, but on problems in the decision making of SCLC leaders. First of all, SCLC leaders had not deeply realized the need to promote local leadership and educate illiterate people, who could not pass literacy exams in order to register as voters, during the initial years of SCLC. As Charles C. Diggs, who was the first African American congressman and a member of the Advisory Board of SCLC, pointed out in his letter to King in March 1958, "Negro voter applicants have dropped below normal. If these reports are true, it would indicate among other things that perhaps the leadership conference has not utilized the political techniques which characterize the success of registration campaigns in certain northern communities." 173

SCLC leaders did not reform the tactical problems of the Crusade for Citizenship during its initial years. Only Baker had insisted on the crucial role of workshops for local leadership during those years; however, her voice was ignored by the hierarchy of SCLC clerical leaders who wanted to strengthen the headquarters of SCLC and be the center of the civil rights movement. Moreover, the proposals from the ACRC, the MCFC, and Mason could not provide solutions that would relieve the financial problems of SCLC or tactics that

172 "Proposed Plans for Kick-off Meetings," KPBU, 113:1; and Mason, "SCLC Professional Correspondence," November 22, 1958, KPBU, 108:2.

173 Diggs to King, March 17, 1958, KPBU, 108:2. 
would be able to develop the voting rights drive to a Southern-wide level. In this context, the HFS's Citizenship School successfully provided solutions to SCLC, which had been struggling with the lagging of the Crusade for Citizenship. 


\section{Chapter Two}

\section{Reaching People at the Grass Roots: The Citizenship Education Program of SCLC}

The operation of Citizenship Schools is most critical at this time because the grassroots people can be helped to understand the vote-realizing how it can help them personally to participate in the achievement of good government thereby improving their own lot in life. ${ }^{174}$

Lacking budgeted funds and specific tactics, SCLC could not train Southern people locally to register to vote. The radical tactics of direct action, such as frequent boycotts and picketing, did not appeal to local people, who needed to learn why they had to overcome their reluctance and risk their jobs and businesses in the name of justice. ${ }^{175}$ The adoption of the HFS's Citizenship School enabled the people of SCLC to recognize the need for grassroots organizers to train local leadership, so this local leadership could create a dynamic whereby African Americans realized the value of their own civil rights. Besides SCLC, student organizations such as SNCC also adopted the HFS's education programs for voting rights, and they were able to train and produce the civil rights leaders who successfully desegregated voting rights in 1965. Moreover, the HFS's Citizenship School, which was founded by women leaders, allowed women and young people to be trained as leaders, and it changed the old leadership systems of the civil rights movement, which had focused on the male and heroic clerical leaders. Andrew Young, part of the new generation of SCLC leaders, worked for the Citizenship Education Program (CEP) with deep respect for the contributions of women leaders, such as Ella Baker and Septima Clark, who had laid the foundations for grassroots leadership. Through awakening local people to realize and win the dignity of human rights, the HFS's Citizenship School played a groundbreaking role in SCLC and the civil rights movement of the 1960s.

174 Citizenship Education Program, "Reports to Foundation May-Dec. 1961," December 11, 1961, KPKC, 136:28.

175 Ibid., 54. 
The Crusade for Citizenship, which kicked off on February 12, 1958, was the first major program of SCLC. It was the program project that King and SCLC leaders organized and differentiated from the mass meetings they had led, such as the Montgomery Bus Boycott and the Prayer Pilgrimage. After about two years' stagnation in creating a dynamic for change, SCLC leaders realized that their tactics and leadership strategies had been the main causes for the failure to initiate the Southern-wide project of the Crusade for Citizenship. As Baker pointed out, King realized that SCLC needed to shift its outlook to the blind spots keeping its leaders from seeing what the segregated people really needed. On October 12 , 1960, SCLC board members reorganized its administrative committee, which had consisted of thirteen members, by narrowing it to a five-member subcommittee to assist the executive director. ${ }^{176}$ The students' sit-ins and the establishment of SNCC infused new energy into SCLC, which was affiliated with the student organizations, to revive financial support and the voting rights movements in 1960. The students' movements had originated from their understanding of the need for civil rights tactics that showed sympathy for the sorrows of segregated local people.

SCLC developed the CEP as a program that could enlighten people about human rights based on Christian values. The new leaders, Septima Clark and Bernice Robinson, who were the directors of the HFS's Citizenship School, formatted the programs of the CEP, imbuing them with Christian teachings about human rights and justice that stood in contrast to the socially segregated system of their day. Dorothy Cotton and Andrew Young, who were hired to direct the CEP, also developed citizenship schools that were based on Christian ideas that were in accordance with King's social gospel. These new leaders of the CEP were different from the hierarchical clergy leaders of SCLC because they were equipped with different religious experiences with young and uneducated African Americans in local areas.

176 Fairclough, To Redeem the Soul of America, 55. 
The Marshall Field Foundation fundraised for the CEP and provided it with sustainable support; thus, the CEP set up hundreds of local centers to train indigenous leaders in their communities. This chapter analyzes the process of adopting and developing the CEP and its success and impact as a Southern-wide movement for civil rights based on Christian thinking about humanity.

\section{Adoption of the HFS's Citizenship School by SCLC}

SCLC hired Wyatt Tee Walker to take Baker's position as executive director in 1960. As the new director, Walker needed to develop the Crusade for Citizenship program and break through its obstacles to increasing the number of voters in local Southern areas. Walker recommended that SCLC hire James R. Wood and Dorothy Cotton, who had worked with him previously, and the Reverend Harry Blake, who had experience with a voter registration drives in Louisiana. ${ }^{177}$ At the annual meeting of SCLC on October 11, 1960, Walker proposed that SCLC adopt the HFS's Citizenship School model for training local leaders. ${ }^{178}$ Walker's suggestion came on the heels of Horton's and Clark's frequent invitations to visit the HFS's Citizenship School and Baker's insistence that a program of citizenship education for local adults needed to be initiated. Walker's proposal was also a timely suggestion for SCLC, which wanted to create an alternative program to reactivate the work of the lagging Crusade for Citizenship. Following this meeting, SCLC began an HFS-style Citizenship School program in Shreveport, Louisiana. ${ }^{179}$

After this annual meeting of SCLC, in October 1960, Walker sent Wood to look into the process of adopting the HFS's Citizenship School. While he stayed at the HFS, Wood had “intensive conversations" with Myles Horton, Septima Clark, and Mrs. Alice Cobb, who was

177 Ibid., 67.

178 King, Papers of Martin Luther King, vol. 7, 136.

179 The public report of the unanimous agreement for adoption of this program was made at the SCLC staff meeting on May 8, 1961. See Myles Horton to Dr. Wesley Hotchkiss, June 26, 1961, KPKC 136:10. 
an education director. ${ }^{180}$ From this exploratory visit, Wood realized that the HFS's programs for citizenship education were fully in accord with SCLC's need to develop voting rights drives. After his detailed overview of the structure and practices of the HFS's Citizenship School, Wood affirmed, "The need of SCLC for a program to develop leadership on a wide basis in the community is most necessary to implementing organization and action at the grass-roots level. The plan now in use by Highlander meets our needs with very minor changes." 181 Horton also introduced Wood to Lawrence B. Moore, who was an executive of the Marshall Field Foundation. Unofficially, Wood discussed with Moore the possibility of giving a grant to SCLC from the Field Foundation if SCLC adopted the HFS's Citizenship School. Seeking to persuade Moore, Wood insisted that a grant from the Field Foundation would provide crucial assistance to SCLC by allowing them to hire full-time field directors to set up Southern-wide voter registration drives through citizenship education. Clark suggested to them that she could take on the same position in SCLC as her role as a director of the HFS. ${ }^{182}$ Based on these agreements, Wood believed that SCLC could adopt the HFS's Citizenship School, and he urged SCLC leaders to initiate the process of adoption.

As administrative assistants to Walker, Cotton and Wood visited the HFS in the last weeks of December 1960 and the first weeks of 1961 to fulfill their responsibility of taking over the Citizenship School. In addition, SCLC organized a team that would recruit for and enhance the workshops and curriculum of Clark and Horton's curriculum. SCLC initiated the CEP and put in place full-time and half-time employees: Andrew Young, Dorothy Cotton, and Annell Ponder - all of whom had recently been hired - and Septima Clark and Bernice Robinson, who had worked as the directors of the HFS's Citizenship School. Soon after,

180 James R. Wood, "Highlander Folk School in 1960," November 11-13, 1960, KPKC, 136:8.

181 Ibid.

182 Ibid. 
Victoria Gray Adams, Carl Farris, B. J. Johnson, and Benjamin J. Mack were added to the roster of CEP workers. ${ }^{183}$ Young, who was working for a pastor of a Congregational church, arranged for SCLC to purchase the church's building in McIntosh, Georgia. The building had served as a church-sponsored community center and been used as a school for training African Americans. ${ }^{184}$ SCLC renovated this building, made it the headquarters for running workshops, and named it the Dorchester Center.

Young played a crucial role in setting up the administrative work of the CEP. In addition to working for a Congregational pastor, he had served as a conference organizer for the youth division of the National Council of Churches (NCC). When he heard about students' sit-ins, Young eagerly wanted to join in the civil rights movement in order to expand his experience with youth. ${ }^{185}$ Young visited the HFS in 1960 because the NCC wanted him to review the HFS's need for the NCC's support. While he was visiting the HFS, Young was able to meet many leaders of the Nashville sit-in. As a result, he felt the HFS was a "twentieth-century oasis in the Tennessee Mountains." 186 Young also wrote a letter to King in which he shared Horton's advice to him about what position in the civil rights movement was fitting for him. Horton suggested that Young work as a supervisor of the HFS, while King wanted him to come to work for SCLC in the spring of $1961 .^{187}$ Young took Horton's advice, deciding to work as a full-time supervisor of the HFS under the grant from the Field Foundation. The reason why Young declined King's invitation was that he wanted to develop his career as a conference organizer for young people, and he felt uncomfortable with

\footnotetext{
${ }^{183}$ Wood took over the position of press secretary for SCLC. See Young, An Easy Burden, 138.

184 Dorothy F. Cotton, If Your Back's Not Bent: The Role of the Citizenship Education Program in the Civil Rights Movement (New York: Atria Books, 2012), 112.

185 Young, An Easy Burden, 129.

186 Ibid., 130.

187 Ibid., 130-131.
} 
SCLC's Southern black Baptist background. ${ }^{188}$ Young had to change his plans, however, because the Tennessee courts ordered the HFS to close, and they tried to confiscate its property because Clark had been accused of bootlegging. ${ }^{189}$ Thus, Young went to work for SCLC as Horton and King recommended.

Young played an essential role in getting a grant from the Marshall Field Foundation. Even though Baker, King, Horton, and Wood had suggested the possibility of getting such a grant, Young paved the way for SCLC to receive it. Using his contacts with tax-exempt social organizations, Young was able to persuade Dr. Wesley Hotchkiss, who was working as the General Secretary of the American Missionary Association (AMA), to act as a gobetween to transfer the Field Foundation's grant from the HFS to SCLC, so SCLC could avoid a tax levy. The Field Foundation and the AMA wanted to support the organization of citizenship education programs in connection with black churches. Hotchkiss was concerned with SCLC's adoption of the HFS's education program because the HFS had been rumored to be a secular school for training communists. Young strongly insisted that the HFS's Citizenship School and SCLC's CEP were lay education programs with strong Christian philosophies. Young scheduled a CEP committee meeting with Horton, SCLC leaders, and officials of the AMA and Field Foundation to clarify the spiritual potential of the CEP. ${ }^{190}$ The Field Foundation's grant was transferred to the CEP through the AMA in 1961. This fund enabled SCLC to set up an independent financial system just for the CEP, so the directors and workers of the CEP could initiate their workshop programs without engaging in a complicated process of sharing a budget with SCLC headquarters.

\footnotetext{
188 Ibid.

189 Clark demonstrated her innocence and how the Tennessee police officers' raid on the HFS was unjustified in her book Ready from Within, 57-59.

190 Andrew Young to Dr. Hotchkiss, June 26, 1961, KPKC, 136:2.
} 
In order to pay him a salary, Young was placed as an employee in the United Church Board for Homeland Ministries (of which the AMA was a part), and all citizenship education grants of the Field Foundation were transferred to the CEP. Through the payment of Young's salary, the AMA was able to transfer funding to the CEP for its other expenses, including its workers' salaries. ${ }^{191}$ Thus, all staff of the CEP were financially employees of the AMA; however, they were also administratively staff members of SCLC. ${ }^{192}$ SCLC's purchase of the Dorchester Center was connected to the Field Foundation grant because the building's title belonged to the United Church Board for Homeland Ministries, which wanted to improve this building for citizenship education and had to pay Young's salary in order to transfer the grant to the CEP. ${ }^{193}$ Young began working as an executive secretary of the CEP, Clark as an educational director, Cotton as an educational consultant, and Robinson and Ponder as field supervisors. With these staff members of the CEP located at the Dorchester Center, the CEP began to initiate five-day residential workshops for local people to "discover their capacity to solve their individual and community problems." 194

\section{The HFS Transfers the Citizenship School to SCLC's CEP}

According to Horton's description, SCLC's adoption of the HFS's Citizenship School meant engaging in "cutting-edge programs that no one else in the region was undertaking" during the civil rights movement. ${ }^{195}$ Horton studied with and engaged in social activities with Reinhold Niebuhr when he was attending Union Theological Seminary. He was strongly influenced by Niebuhr's socialist Christian thinking. ${ }^{196}$ While he was visiting Jane Addams' Hull House in Chicago and folk schools in Denmark, Horton began developing his idea to

\footnotetext{
191 Cotton, If Your Back's Not Bent, 108.

192 Ibid.

193 Young, An Easy Burden, 134.

194 Cotton, If Your Back's Not Bent, 112.

195 Myles Horton, The Long Haul: An Autobiography (New York: Teachers College Press, 1998), 139.

196 Ibid., 35.
} 
establish a local school for the poor and laborers in Appalachia. ${ }^{197}$ With the help of Niebuhr's fundraising, Horton began the HFS in Monteagle, Tennessee, in 1932. Horton traveled all around the South to meet with young students and fundraise for the HFS. He arranged workshops which had as goals changing social problems and integrating blacks, whites, women, men, poor people, laborers, students, rich people, and educated people. Horton had focused on using the Congress of Industrial Organizations' session for training labor union workers and working against racial segregation in the labor movement. The HFS had been mainly working with labor unions, such as the Packinghouse Workers Union; however, this shifted after Esau Jenkins, who was a businessman and a director of adult education schools on Johns Island, South Carolina, visited the HFS for a United Nations (UN) workshop and shared his experience of running adult schools for voter registration. ${ }^{198}$ During the UN workshops at the HFS, Horton also met Clark, who helped Jenkins run the citizenship schools, and he visited Johns Island in 1955 to learn how their workshop programs operated.

Clark had earned a certificate to teach in 1916, and her first teaching job was with elementary school students on Johns Island. She found out that there were many illiterate African American adults, and she began teaching them how to read and write after school. When Jenkins was fourteen, he went to Clark's class and learned reading and writing. ${ }^{199}$ The HFS's Citizenship School originated from the citizenship education programs on Johns Island, which were adult schools for voting rights. Jenkins drove a commuter bus and running motels and restaurants. He gave rides to people on Johns Island to attend citizenship classes and register to vote in Charleston. When a white man on Johns Island shot an African American boy because the boy accidently killed his dog, Jenkins lamented that the local

\footnotetext{
197 Ibid., 47-61.

198 Ibid., 99-100.

199 Clark, Ready from Within, 42.
} 
African Americans did not resist this brutality. ${ }^{200}$ He realized that the main reason for his people's inaction was not having political power. When he discovered that the public adult schools were not helpful to illiterate African Americans who needed to pass the literacy exam in order to vote, Jenkins, with Clark's help, decided to educate and challenge the local African Americans to vote. ${ }^{201}$

Clark and Jenkins taught illiterate African Americans how to sign their names in cursive script. Jenkins shared the sample form and requirements for voter registration with his bus passengers and distributed copies of the sample questions and answers for the literacy exam to take home to study. ${ }^{202}$ Clark and Jenkins successfully educated many illiterate adults from Johns Island to register as voters. Their citizenship classes were different from other voter registration programs, which just helped illiterate people register. Clark and Jenkins not only taught local people how to register as voters but also helped them to realize the value of their individual rights as voters. They taught them how to use their political power and resist racism through exercising their voting rights. ${ }^{203}$ Clark and Jenkins also encouraged their students to discover their emerging political needs through developing their self-awareness.

Before Clark and Jenkins met Horton, their citizenship schools had problems with expanding their programs. They had been helping the local people get food and immunizations, along with helping them register to vote. ${ }^{204}$ Even though Clark and Jenkins tried to set up a school on Johns Island, they could not find a proper building in which to run their workshops. ${ }^{205}$ With the help of Horton, Clark and Jenkins were able to purchase an abandoned building on the island, and they developed their Citizenship School program in

\footnotetext{
200 Cotton, If Your Back's Not Bent, 99.

201 Clark, Ready from Within, 42; and Young, An Easy Burden, 140.

202 Cotton, If Your Back's Not Bent, 100.

203 Ibid., 101.

204 Septima P. Clark, Echo in My Soul, ed. LeGette Blythe (New York: E. P. Dutton and Co., 1962), 138.

205 Ibid., 139.
} 
this building. ${ }^{206}$ After taking the UN workshop at the HFS, Jenkins had the confidence to teach and manage the adult education programs for voting rights in broader areas. $\mathrm{He}$ developed the skills to teach illiterate people on Johns Island about laws, how to practice their legal rights, and voting requirements.

Clark was fired from her job with the public schools in 1955 because she would not abandon her membership with the NAACP. She had been a public school teacher since she was eighteen. In 1955, Clark began working as a full-time director of the HFS's workshops. To accommodate her work as a public school teacher and her work for the voting rights of the people on Johns Island, Clark used to move back and forth between Johns Island and Charleston. Clark's years in Charleston made the poor people of Johns Island feel alienated from her; thus, Jenkins, who never left Johns Island, became better acquainted with the needs of the people on the island, and he developed detailed programs that addressed these needs. ${ }^{207}$

Clark persuaded her cousin Bernice Robinson, who was a beautician, to teach illiterate people on Johns Island. Robinson also attended a two-week UN workshop at the HFS and joined in developing the voter education program on Johns Island. ${ }^{208}$ Robinson found out that the people in her class wanted to learn through a graduated curriculum. In the beginning of their learning, the people wanted her to teach them how to write their names. For the next step, they wanted to learn how to read the election laws of South Carolina, write some of the words in the laws, and define the words so they could pass the literacy test. After this step, they wished to learn how to write and fill out forms, so they could do such things as write letters and purchase money orders. ${ }^{209}$ Using Clark's advice, which was based on her

206 "Citizenship School," with capital letters, was used for the HFS's collaborative program and the residential workshop of the HFS, and "citizenship schools," with lowercase letters, was generally used for the local branch workshops of the Citizenship School program.

207 Clark, Echo in My Soul, 144-145.

208 Ibid.

209 Ibid., 146-147. 
thirty years of experience teaching illiterate people, Robinson successfully taught her pupils to write their names in cursive through tracing letters on pieces of cardboard. ${ }^{210}$ Clark created a workbook to introduce illiterate adults to the legal issues of South Carolina, such as the requirements and rights of voting, social security, taxes, and current social matters. Using simple words to explain legal issues, Clark was able to remind these adults to be proud of using their voting rights as first-class citizens. ${ }^{211}$

The first HFS Citizenship School workshop was held on Johns Island, and Clark, Horton, Jenkins, and Robinson stayed there during that time. It was a three-month program, and students attended the school twice a week. Among the thirty-seven students of this program, eighty percent of them were able to register to vote at the end of the program. ${ }^{212}$ When the people on Wadmalaw Island and Edisto Island, which are near Johns Island, heard about this success, they begged the HFS staff to set up the Citizenship School program in their communities. ${ }^{213}$ The Citizenship School rapidly developed into an island-hopping program of adult education workshops, hosting workshops on other islands in the Sea Islands and in communities in Charleston from 1957 to $1959 .{ }^{214}$ Based in church buildings, the HFS's Citizenship School program successfully responded to the problems of local people, who were segregated without their voting rights. In one community on Johns Island, there were only thirty people who were registered to vote in 1956; however, after the citizenship schools were set up, about seven hundred voters - almost 100 percent of the people in this community — were able to be registered in 1957. As a result of this increase in the number of

\footnotetext{
210 Ibid., 148.

211 Ibid., 150.

212 Horton, The Long Haul, 103.

213 Ibid.; and Frank Adams with Myles Horton, Unearthing Seeds of Fire: The Idea of Highlander (Winston-Salem: John F. Blair, 1998), 117.

214 John M. Glen, Highlander: No Ordinary School 1932-1962 (Lexington: University Press of Kentucky, 1988), 165.
} 
voters, the community's public schools, roads, and public health facilities were improved. ${ }^{215}$ From 1956 to 1961, the number of African American voters on Johns Island increased about 300 percent, and from 1958 to 1960, the number of African American voters on Edisto Island increased fivefold. ${ }^{216}$ Jenkins estimated that about 14,000 African American were registered and voted in Charleston County in 1960, and this number outweighed the number of white voters, which was the first time this had happened in the history of Edisto Island and Wadmalaw Island. ${ }^{217}$

The HFS's Citizenship School workshops in Charleston County began as an experimental challenge for the HFS staff. As a result of four years of hard work, this experiment generated tremendous success, increasing the number of African American voters and their political power. Beginning in 1960, the HFS staff of the Citizenship School decided to promote the Southern-wide impact of voting rights drives for African Americans by establishing Citizenship School workshops in Huntsville, Alabama, and Savannah, Georgia. ${ }^{218}$ Thanks to the teacher training workshops of the HFS, which were one-week programs, in 1960 there were four Citizenship School teachers who were able to establish three citizenship schools in Savannah. ${ }^{219}$ Using similar tactics and teaching materials as the Citizenship School workshops in the Sea Islands, these workshops increased the number of African American voters in the three areas that had schools. From November 1960 to January 1961, Clark and other staff members and teachers of the citizenship schools in the different areas had workshops at the HFS to develop their teaching methods and programs. Moreover, by April 1961, there were about sixty teachers who were trained to teach and lead the

215 Highlander Folk School, "Proposed Citizenship School Training Program, Highlander Folk School," December 1960, KPKC, 136:9.

216 Glen, Highlander, 165.

217 Ibid., 166.

218 Ibid., 167.

219 Ibid. 
Citizenship School program. They were from the Montgomery Improvement Association, SCLC, and other civil rights organizations. ${ }^{220}$ This notable expansion of the HFS's

Citizenship School caused Horton to feel the burden of handling the huge needs of building Citizenship School programs in various local communities. Horton talked several times with King and asked him to adopt this program into the Southern-wide voting rights efforts of SCLC. ${ }^{221}$ In addition, several times Clark contacted King and Baker (who was working for SCLC at the time) to ask them to help develop the Citizenship School. ${ }^{222}$

There had been attacks on the HFS from white racists who loathed the racial integration policy of the HFS. The HFS also experienced red-baiting because of Horton's support for labor unions. ${ }^{223}$ Ironically, however, Horton's socialistic convictions conflicted with the Congress of Industrial Organizations' anticommunist policy when the CIO included a provision for communist expulsion in its bylaws. Horton resisted this provision and made a decision to switch the social work of the HFS from educational projects for labor unions to the new direction of voting rights for illiterate African Americans. ${ }^{224}$ Having uncompromising goals for the rights of people at the grass roots, the HFS had suffered from its beginnings at the hands of opponents who attacked the HFS because of its work for racial integration and labor unions.

When Horton left the HFS to visit Europe in 1959, there was another act of violence by Tennessee police officers, who arrested Clark after entrapping her in bootlegging. ${ }^{225}$ The police officers made a raid on Clark's workshop at the HFS and found a demijohn in Horton's house that was full of cobwebs and looked like a bottle of country moonshine. Even

\footnotetext{
220 Ibid., 168.

221 Horton, The Long Haul, 107.

${ }^{222}$ Ella Baker to Septima Clark, April 14, 1960, KPKC, 154:1; and Clark to King, March 23, 1960, KPBU, 112: F3.

${ }_{223}$ Glen, Highlander, 67.

224 Horton, The Long Haul, 97.

225 Clark, Ready from Within, 57.
} 
though Clark never bootlegged in the HFS, she had to pay $\$ 500$ to bail herself out of jail. The HFS had to face the crisis that the state of Tennessee had pushed to shut it down. After the raid in 1959, Clark and Horton made a decision to transfer the Citizenship School program to SCLC, even though the court's padlocking order was delayed because the judge could not find any evidence of bootlegging, and their appeal to the United States Supreme Court was pending. ${ }^{226}$ In 1961, the HFS was renamed the Highlander Research and Education Center and moved to Knoxville, Tennessee, because the state of Tennessee confiscated HFS's building in New Market. ${ }^{227}$ The HFS had two main reasons for transferring the Citizenship School program to SCLC: the program was too big to be maintained by the HFS and the crisis of being padlocked by the Tennessee Supreme Court. ${ }^{228}$

By 1961, there were fifty-four teachers (out of sixty total trainees) who had been trained by the HFS's Citizenship School program and could lead this program in their communities. ${ }^{229}$ Horton sent these trained teachers to the affiliated organizations of the HFS, which were SCLC's Southern-affiliated organizations, such as the Chatham County Crusade for Voters of Savannah, the Southeastern Georgia Crusade for Voters, the Madison County Voters League of Huntsville, the Haywood County Civic and Welfare League in Alabama and the Original Fayette County Civic and Welfare League in West Tennessee. ${ }^{230}$ Since its first class on Johns Island in 1955, the HFS's Citizenship School had developed its tactics, curricula, and teaching materials for the African American grass roots in the South. In 1961, Horton and Clark scheduled twenty-two workshops at the HFS to train 350 teachers, which would lead to having over 20,000 students who could pass the literacy exam and have first-

226 Clark, Echo in My Soul, 213.

227 The HFS moved to Knoxville before the state of Tennessee ordered it padlocked. See Clark, Ready from Within, 61.

228 Horton, The Long Haul, 107.

229 Clark, Echo in My Soul, 212.

230 Ibid. 
class citizenship. ${ }^{231}$ Through the influence of the HFS's UN workshops, Clark and Jenkins were able to realize their vision of educating people who could become leaders for their local communities when they completed the Citizenship School program. Thus, as the local leaders for registering African Americans to vote, Clark, Jenkins, and Horton influenced each other as they developed the grassroots tactics for the Citizenship School program over the course of about seven years and expanded this program into a Southern-wide local movement.

Following the success of the pilot Citizenship School program in the Sea Islands, the HFS staff made plans for expanding this program into other areas, and they set up workshops at the HFS to train young teachers who were currently engaged in the student sit-in movement. ${ }^{232}$ The HFS's Citizenship School program tried to focus on two goals: expanding its influence on local communities through establishing voting education schools in local areas and on training young leaders for racial integration movements, such as sit-ins, through workshops at the HFS. In 1960, the HFS leaders asked the Schwarzhaupt Foundation for support for the youth leadership workshops at the HFS. ${ }^{233}$ Transferring the Citizenship School to SCLC did not mean stopping this program of the HFS; rather, local adult schools were begun through SCLC's Citizenship Education Program, and the HFS focused on workshops for young leaders to train them as local community leaders. In spite of the crisis of being padlocked, the HFS vigorously expanded the Citizenship School program in various areas. While the HFS continued its workshop programs, the Citizenship School was satiating the HFS's and SCLC's needs to expand voter registration drives. Moreover, SCLC's CEP, which had adopted the HFS's Citizenship School, was combining the efforts to empower

\footnotetext{
231 Ibid., 211-212.

${ }^{232}$ Highlander Folk School, "Minutes of Executive Council Meeting," July 21-22, 1960, KPKC, 154:1.

233 Ibid.
} 
grassroots leadership through the social work of the HFS, SCLC, and the adult education schools on Johns Island run by Clark and Jenkins.

The Citizenship School Committee was a committee organized to help the HFS and SCLC transfer and adopt the Citizenship School program. The Citizenship School Committee members were "Jim Wood, an administrative assistant to Rev. Martin Luther King, Jr., of SCLC; Herman Long, the director of the Race Relations Department of the American Missionary Association of the Congregational Church; and Myles Horton, the director of the Highlander Folk School." 234 The committee members made plans for supervising the process of the adoption of the Citizenship School by SCLC and for raising funds to develop this program at a Southern-wide level. The committee confirmed the Field Foundation's grant of $\$ 26,000$ for SCLC to initiate the Citizenship School program and have a tax exemption through the American Missionary Association of the Congregational Church. ${ }^{235}$ Under the committee's supervision, Clark was hired by SCLC on a full-time basis, with a guaranteed annual wage of $\$ 6,600 .{ }^{236}$ The committee also tried to get nationwide publicity for the Citizenship School program through articles and TV clips. ${ }^{237}$ On December 1, 1960, the HFS and SCLC made a financial agreement for SCLC's adoption of the Citizenship School as the committee members supervised. These two organizations confirmed the full-time position of Clark in SCLC. They also agreed that SCLC would fully pay for the traveling expenses, tuitions, and room and board expenses of staff members of SCLC and the HFS while they attended the Proposed Citizenship School Training Program, which was organized for training SCLC's staff members how to run the HFS's Citizenship School. ${ }^{238}$

\footnotetext{
234 “Citizenship School Committee Meeting,” June 8, 1961, KPKC, 136:28.

235 Young suggested the tax exemption through the American Missionary Association, and the committee supported his idea.

236 "Citizenship School Committee Meeting," June 8, 1961.

237 Ibid.

${ }^{238}$ SCLC, "Memorandum on: SCLC-Highlander Financial Agreements," December 1, 1960, KPKC, 136:9.
} 


\section{The Tactics and Development of SCLC's Citizenship Education Program}

Horton testified that the success of the Citizenship School was due to its teachers' proper attitudes toward their adult students. ${ }^{239}$ Even though the citizenship schools in the Sea Islands area usually used the teaching materials and classrooms designed for the elementary school students, Robinson realized that the adults in her classes did not want her to treat them like elementary-aged children. She found that her students did not want her to teach them using the same alphabet cards used with elementary school students, and they refused to use the children's small chairs and desks. Being familiar with the needs and desires of her adult students, Robinson decorated her classrooms with copies of the UN Declaration of Human Rights, and she asked them adult level questions: "Were they, as a people, responsible for their mean condition? Were they ignorant and unable to learn, as was said of them? Were they filled with sloth, treachery, or incompetence?" 240 Moreover, Horton tried to decentralize the authority of teachers and the racial supremacy of white supporters of integration; thus, the teachers of the Citizenship School helped their African American students actively participate in their classes and the running of the school. ${ }^{241}$

Clark organized the CEP according to her experience and philosophy, just as she had at the HFS. Clark and Horton, who had met at the HFS's UN workshops in 1954, shared a common philosophy developed from their fieldwork experiences for empowering the selfawareness of grassroots people. The main philosophy of the HFS's Citizenship School was helping grassroots people realize for themselves their power and helping them solve their problems. ${ }^{242}$ This philosophy was maintained by the CEP leaders because Clark was the major organizer of the CEP, and the other main leaders of the program, such as Cotton and

\footnotetext{
239 Adams, Unearthing Seeds of Fire, 119.

240 Ibid.

241 Ibid., 118.

242 Cotton, If Your Back's Not Bent, 102.
} 
Young, were young and not accustomed to the hierarchical leadership structure of SCLC. The CEP's independent funding from the Field Foundation also contributed to the development of their grassroots tactics. These tactics stood in contradistinction to the methods of SCLC headquarters, which was dominated by hierarchical clerical leadership. ${ }^{243}$ Because Baker insisted on the independence of the Crusade for Citizenship's staff members, the work of the CEP was able to provide a solution for SCLC's hierarchical leadership problem.

In 1961, Clark began working for the CEP at the Dorchester Cooperative Community Center. She was satisfied with her new position in the CEP because she was able to continue doing workshop programs as she did in the HFS. ${ }^{244}$ In the brochure, This Is SCLC, Clark described the basic format of the CEP:

Interested persons, who have a general knowledge of reading and writing, are trained intensively in the skills of adult education using subject matter relevant to the social struggle. They return to their individual communities as instructors and set up a Citizenship School that the "grass-roots" people may be trained for full participation in civil life. Periodically, the instructors return to the training center for refresher courses to keep them abreast of significant changes and to further develop their skills. ${ }^{245}$

This description demonstrates that the CEP was an ongoing program to educate grassroots leaders for their communities and not a once-for-all program for local people. Clark thought that the disheartening conditions of segregated African American life could not be changed unless civil rights activists could reach the grassroots people of the nation. She requested that the CEP teachers be psychologically and competently trained to work directly with the problems of the grassroots communities. ${ }^{246}$ From the beginning of the CEP, this tactic of focusing on grassroots leadership was necessary for its effectiveness, as Young's memorandum in 1961 explained:

243 According to Young, the Field Foundation began its grant to the CEP in October 1961. Andrew Young to W. A. Hotchkiss, October 3, 1961, KPKC, 136:2.

${ }^{244}$ Clark, Echo in My Soul, 214-215.

245 SCLC, This is SCLC, in Clark, Echo in My Soul, 215-216.

246 Ibid., 238-239. 
The selection of the "right" leaders for these 240 training opportunities is also of prime importance to the overall effectiveness of the program. Few organizations have the opportunity to give five days of concentrated training to local workers in their movements. The right people in these training classes could give SCLC a broad base of trained leadership across the South at the grass roots level. ${ }^{247}$

As Young noted, the CEP was different from other organizations doing voting rights education, which were primarily focused on passing the literacy exam; the CEP was an unusual organization in that it used the term "the grass roots," and it specialized in developing grassroots leadership. ${ }^{248}$ Thus, the CEP began with the new philosophy of empowering the grassroots leadership, an approach that SCLC leaders had not practiced before the CEP began. Moreover, the CEP brought to fruition the philosophy of Clark and Horton, who believed that grassroots leadership could solve the problems of African American communities dealing with racial segregation.

Besides Clark's and Robinson's influences, one of the main reasons for the CEP's quick adaptation to the Citizenship School's program and philosophy was the deep understanding of the value of grassroots leadership by the new staff members of SCLC: Cotton and Young. Before the CEP was officially initiated, Cotton was sent by SCLC to spend time on Johns Island exploring the Citizenship School program as a potential member. During that time, Cotton realized the potential power of the Citizenship School, which enabled grassroots people to develop their own power to overcome social injustice. It was for her "the pivotal moment" in which she understood the potential for grassroots tactics to spread across the South and create Southern-wide success for the civil rights movement. ${ }^{249}$ Unlike Young, who had a different denominational background from SCLC's Southern

247 Andrew Young, "Memorandum: A Proposed Strategy for the Citizenship School Program," sent to SCLC, the Citizenship School Committee, the American Missionary Association, and the Field Foundation, 1961, KPKC, 136:2.

${ }^{248}$ For comparison to other voting rights education programs, see chapter one, "Prior Voting Rights Workshops."

${ }^{249}$ Cotton, If Your Back's Not Bent, 103. 
Baptist pastors, Cotton had worked with Reverend Walker for over six years in the Gillfield Baptist Church in Petersburg, Virginia, and during her college years, she was acquainted with Dr. Vernon Johns, who had previously been King's pastor at the Dexter Avenue Baptist Church. Even though she had been close to these charismatic Baptist preachers, Cotton was able to quickly accept the new tactics for the civil rights movement - the grassroots leadership of the Citizenship School—-because of her experience of its success on Johns Island. ${ }^{250}$

Based on the experience and success of the grassroots tactics, the CEP quickly expanded and grew in dynamics. The CEP staff worked hard to set up 240 opportunities to train local leaders in 1961, and staff members traveled to the key cities of the South such as Tallahassee, New Orleans, and Birmingham to establish and operate citizenship schools in local areas. Teacher training workshops were continually operating, and there was an ongoing pool of applicants who came from diverse places: South Carolina, Mississippi, Alabama, Georgia and Florida. ${ }^{251}$ Every five-day workshop of the CEP for training teachers had a clear goal, which was helping the grass roots realize their own power, just as Clark and Horton had practiced in the Citizenship School. ${ }^{252}$ According to Cotton's description, SCLC staff learned how to develop its own grassroots tactics through the work of the CEP. Cotton and King called the people who completed the five-day workshop and went backed to teach people in their communities the "ground crew." 253 The CEP's tactics were enough to intensively train the ground crew to have the right perspective for teaching the local people and for embracing the different situations of the diverse organizations of the civil rights movement. The CEP believed that the ground crew consisted of the key activists of the civil rights movement,

\footnotetext{
250 Ibid., 103-104.

251 Andrew Young to Wesley A. Hotchkiss, November 17, 1961, KPKC, 136:2.

252 Cotton, If Your Back's Not Bent, 104.

253 Ibid., 114.
} 
because they could work with the diverse local grassroots people and enable them to participate in the mass movements of the diverse civil rights organizations. ${ }^{254}$

For educating the local people, Clark insisted that the CEP's workers were not to be divided into departments but into groups of home and field supervisors who recruited local people in order to develop their individual initiative. ${ }^{255}$ The field workers of the CEP had to visit Southern cities to meet with local leaders who were ready to organize the Citizenship School program in their areas. Cotton worked as a coordinator who would select and contact influential leaders from among the local people. She could pick out the right people in the training workshops, and then she would send them to work as local coordinators who set up citizenship schools in their communities. ${ }^{256}$ Training local leaders through 240 workshop opportunities in the initial year of the CEP was very successful, just as Clark and Horton had experienced through the Citizenship School of the HFS. The CEP workers realized the potential effects of these trained local leaders, who could coordinate the various SCLC civil rights programs in the future as a nationwide movement. The grassroots tactics of the CEP provided common practical tactics for other key civil rights organizations, such as CORE, the NAACP, the Urban League, and SNCC, that helped them expand their mass movements through such actions as sit-ins, the voting rights march in Selma, and Freedom Rides. ${ }^{257}$ Moreover, the trained local leaders were able to cooperate to develop SCLC's People to People tour and the March on Washington. ${ }^{258}$

\footnotetext{
254 Ibid., 115.

255 Hosea L. Williams, "Report of 'Get Out the Vote' Campaign,” November 1964, KPKC, 135:8.

256 Andrew Young, “A Proposed Strategy for the Citizenship School Program,” KPKC, 136:1.

257 Clark, Ready from Within, 70.

258 Young, An Easy Burden, 153; also see the following pages for a discussion of the expansion of the CEP through grassroots tactics.
} 
During the first two years of the CEP, about 50,000 new voters were registered from eastern Texas to northern Virginia as a result of the CEP's influence. ${ }^{259}$ Among them, there were 10,000 students and community leaders who were directly trained by CEP workshops. ${ }^{260}$ Until 1963, sixty-three citizenship schools had operated and seventeen new schools were added in that year. With the additional influence of King's People to People tour, the number of African American voters increased from 57,000 in April 1962 to 110,000 by November 1962 , and 150,000 voters were registered in $1963 .{ }^{261}$ This dynamic increase in the number of African American voters over a short period of time demonstrates that the new engine of SCLC - the CEP — brought a successful solution to SCLC and pulled it out of its stagnation of the late 1950s. Moreover, this success of the CEP expanded the civil rights of people in their local communities. From a Newberry, South Carolina, workshop held on February 16, 1963, there were several testimonies of the CEP's dynamic influence in the grassroots community:

1) "I learned to read in three months."

2) "I voted during the school term."

3) "I went down to the registrar's office with a neighbor. The neighbor registered."

4) "Our class helped our community to unify."

5) "We learned about new things (social security)."

6) "We did not know there was so much to learn. We are not satisfied with secondclass citizenship."

7) "I have not missed a night. I learned to write."

8) "The class helped me to become a Christian practicing Christianity."

9) "I received my registration card in two weeks."

10) A young high school student said, "I drove my father to school every night. Attending the citizenship school helped me to learn the contributions made by Negroes. I am a senior in Richland County High School and never heard of Benjamin Banneker, Harriett Tubman or Sojourner Truth."

11) A parent from Bamberg County learned how to obtain help for her mentallyretarded child. The girl is now in the State's mentally-retarded school. ${ }^{262}$

259 Septima P. Clark, "Success of SCLC Citizenship School Seen in 50,000 New Registered Voters," SCLC Newsletter, September 1963, KPKC, 122:22.

260 Ibid.

261 Ibid.

262 Ibid. According to the document, the workshop had fifteen teachers and eighty-three students, who came from seven counties. 
These testimonies show that the CEP functioned not only to increase voter registration but also helped in diverse ways the social advancement of local communities, such as increasing the unity of local people, nurturing the younger generation's racial identity, and improving the well-being of disabled children.

In its Citizenship School Workbook, SCLC clarifies the purpose of the CEP. According to this book, the CEP was the immediate plan for targeting the literacy that would enable adult students to pass literacy exams for voting. ${ }^{263}$ Moreover, the CEP's reading and writing curriculum involved "an all-round education in community development" that improved people's home lives, housing, hygiene, and public health. This education program also focused on helping students navigate aspects of public life related to their civil rights, such as "safe driving, social security, cooperatives, the income tax, and understanding of taxsupported resources such as water testing for wells, aid for handicapped children, and the structure and function of our local and national government."264 The local people who did not have first-class citizenship had always faced problems with these elements of social life. Thus, the CEP diagnosed that "the economic situation is a major key to the reason why voterregistration, with all of its restrictions, is crucial, and why the program is needed."265 The CEP's main goal enabled the grassroots people to realize and overcome their social problems by gaining first-class citizenship, and the CEP appealed to other civil rights organizations because this program dealt with the most crucial needs of disenfranchised African Americans. The CEP was able to unify the different civil rights organizations into the voting rights movement, which climaxed in the Selma to Montgomery marches and connected to SCLC's future programs, such as the Chicago Freedom Movement and the Poor People's Campaign.

263 SCLC, Citizenship School Workbook, KPKC, 153:23. Ibid. Ibid. 
There were three kinds of workshops which were organized by the CEP. The CEP began by initiating a five-day workshop for training teachers and supervisors who wanted to set up citizenship schools in their local communities. The Citizenship School was a workshop that took about three to five months to educate local disenfranchised people. The refresher workshop was for teachers and supervisors of the citizenship schools. It was generally a three-day workshop for reporting and analyzing the experience of running the citizenship schools. These three workshops were essential to the setup and development of the CEP's citizenship schools. The contents and materials of the three workshops demonstrate why the CEP's citizenship schools succeeded in developing the local democratic power of African Americans.

The Five-Day Workshop Training

The CEP advertised: "Become a trained leader! Join the Southern Christian Leadership Conference in its efforts to lift our people!"266 The CEP initiated the five-day workshop at the Dorchester Center in 1961 as their first activity. It was designed for local people who wanted to be registered to vote and to teach their local people as they learned. Clark, Cotton, and Young visited various local communities, and they tried to find people who could read and write legibly and wanted to be Citizenship School teachers. The CEP workers wanted to recruit grassroots leaders who were respected by the people in their communities and could write their names in cursive. ${ }^{267}$ When they found these local people who wanted to be registered to vote and were also willing to teach other people the skills they needed to be registered, the CEP workers sent them to register for the five-day workshop at the Dorchester Center. This workshop was basically a residential workshop that was held once a month. The CEP also generally had a refresher workshop meeting every month, at

266 SCLC, "The Test of the Citizenship School's Long Range Effect on Students," 1962 , KPKC, 136:30.

267 Clark, Ready from Within, 63. 
which leaders collected feedback and results from the local citizenship schools. The students of the five-day workshop were not skillful writers and readers; however, when they learned how to read and write and how to exercise their voting rights, they were capable of teaching their local people after they left the workshop. ${ }^{268}$

The CEP developed a philosophy of "helping people help themselves." 269 During the civil rights movements era, this idea was a new tactic of education. The self-awareness tactics of the CEP encouraged adult students to realize their human value and to resist social injustice nonviolently. This philosophy also enabled grassroots people to commit themselves to work for the civil rights of African American communities when they found the value of their own civil rights. ${ }^{270}$ SCLC reported, "It [the CEP] extracted learning from their [adult students'] experiences . . . the adults determined the educational goals, planned the techniques and applied them."271 Like the HFS's Citizenship Schools, the CEP was not restricted to following the curriculum exactly. Each training teacher could have his or her own workbook or curriculum, and the teachers preferred a day-by-day plan. ${ }^{272}$ However, as the supervisor of teacher training, Clark had to stay night after night during the beginning months of the Citizenship School to listen to and analyze the recorded tapes of the workshop's classes, so she could create an appropriate initial structure for the curriculum and lesson plans. ${ }^{273}$ Clark used to begin her classes by asking her students to answer the following questions: "Do you have an employment office in your town? Where is it located?

\footnotetext{
268 Ibid., 64.

269 SCLC, Citizenship School Workbook, KPKC, 153:23.

270 Ibid.

271 Ibid.

272 Clark, Ready from Within, 63.

273 Ibid., 39.
} 
What hours is it open? Have you been there to get work?"274 The teachers of the CEP helped the students write down their answers on dry cleaner bags. ${ }^{275}$

Cotton also asked her students to discuss such questions as, "Why don't you have that job?" (When her students repeatedly complained of some official's wrong treatments.) "Why aren't you on the school board, on the city council, in the legislature, in the mayor's office?"276 She realized that these questions could challenge adult students and enable them to think outside the box. ${ }^{277}$ The discussions during the CEP's workshops caused the students to realize not only their social problems but also their participation and responsibilities in solving the problems. Moreover, students' discussions approached real-life matters, rather than imaginary goals or philosophical statements; thus, the CEP participants explored the causes of their social problems and their power to find practical solutions to them. Robinson used to hang up pictures in her classrooms of Thurgood Marshall, Constance Bennett, Constance Motley, and Harriet Tubman, who had all fought for the rights of African Americans. She asked her students: "How many of you noticed what's up here behind me?" "You know why I did it?" "Do you know who Harriet Tubman is and what she did?"278 The students discussed what they knew about these people, and then Robinson asked them, "Why vote?"279 These discussions helped the students to discover their social problems and what they needed to do to solve those problems. Students' discussions also enabled the CEP to practice its philosophy of focusing on students' self-awareness. Robinson used to tell her students, 'I'm not a teacher. We're here to learn together."280

\footnotetext{
274 Ibid., 63.

275 Ibid.

${ }^{276}$ Cotton, If Your Back's Not Bent, 122.

277 Ibid.

278 Bernice Robinson, "Using the GED as a Vehicle for Community and Labor Education," the text of a talk given on the Citizenship Training Schools, November 17-18, 1979, at the Highlander Center, HFS Archives.

279 Ibid.

280 Ibid.
} 
The teachers of the five-day workshops taught the students: "The best teacher does not tell-but asks. Ask questions of the classes, even though you may have the answer already. This makes the students more interested if they are helped to think through a situation." 281 The CEP detailed the questioning skills future teachers were to use in citizenship classes as follows:

The Art of Questioning:

1. Kind of words used in stating the question.

2. The purpose of the question.

a. Should it lead to an answer of facts?

b. Do you want a comparison?

c. Do you need a description?

d. Should the answer be an analysis?

e. Will a mystery be solved?

f. Will it lead to a polite ending?

g. Will it suggest a challenge?

h. Will a projection into the future be the thing needed at this time? ${ }^{282}$

The CEP teacher training workshops also taught the students how to select a topic and how to lead a discussion. The teachers of the workshops encouraged their students to select topics of their own interest, such as "a community problem or situation, a candidate for public office, a recent newspaper article, a TV show."283 They stimulated their students to develop discussions using the following guidelines:

How to Lead a Discussion:

1. Motivation (pictures, known experiences, etc. always help form participating group)

2. Introduction (title, clarification of words in the participants' frame of thinking, use of authorities, unsolved thinking)

3. Procedure (toss out challenging statements or questions, put small groups to work)

4. Expect outcomes (write on blackboard at end of group discussions or draw out outline of outcomes from entire group)

5. Follow-up (watch for bench-mark facts as session progresses). ${ }^{284}$

These detailed directions for leading discussions demonstrate that the CEP considered the

281 SCLC, “The Test,” KPKC, 136:30.

282 Ibid.

283 Ibid.

284 Ibid. 
success of the workshops to be dependent on students' active participation in discussions.

Clark understood that one of the reasons why the CEP succeeded in fostering grass roots leaders was that Robinson "asked the adults what it is they thought they needed to know."285

According to Cotton, the CEP's five-day teacher training workshops were intended to raise up people with solid purposes. Cotton encouraged the students of the CEP to escape their mentality of being victimized. She highlighted the goal "to learn to no longer feel like a victim because of race, poverty, or any unjust system."286 By learning the stories of African Americans who fought for freedom, such as Sojourner Truth and Harriet Tubman, the CEP helped its students gain a self-awareness of their racial identity. Promoting this selfawareness could change the victimhood mentality of the CEP's students into positive energy to protest against the brainwashed idea of racial inferiority. Moreover, the CEP taught its students how to coalesce into groups that could develop their positive energy into real fights for social justice.

The five-day workshops had around fifty to sixty students in each workshop, and the first workshop of the CEP contained the key people of the voting rights movement, such as Fannie Lou Hamer, John Lewis, James Bevel, and Diane Nash. ${ }^{287}$ Cotton's methods for the five-day workshop demonstrate that the CEP recognized the power of self-awareness as the most crucial element of the voting rights movement. Moreover, Cotton's statement above manifests that the CEP's work concentrated not only on educational functions but also on building up a social movement that would closely connect with the mass movements of the civil rights era. Highlighting self-awareness tactics, the local leaders who were trained at the CEP workshops expanded the number of places hosting voting rights movements. As in the

285 "Interview with Septima Clark," by Sandra Brenneman Oldendorf, at Mrs. Clark's home, Charleston, South Carolina, January 17, 1986, HFS Archives.

286 Cotton, If Your Back's Not Bent, 112-113.

287 For more on the key leaders who attended the CEP's workshops, see the following pages. 
cases of Hamer, Lewis, and Nash, who mainly worked for SNCC, the CEP created a new wave of local movements through grassroots leaders who were not restricted by SCLC's boundaries.

The schedule of the five-day workshop was not very tight, but relaxed; although it was intensive in terms of topics. For the students' eating and sleeping, the five-day workshop provided buffet-style meals with homemade cooking and comfortable beds in the Dorchester Center. ${ }^{288}$ The CEP teachers treated the students like family by providing them with homelike board and lodging. ${ }^{289}$ Sharing rooms and eating together made the students and teachers feel like they were living together as a family. ${ }^{290}$ A sample schedule of the five-day workshop follows.

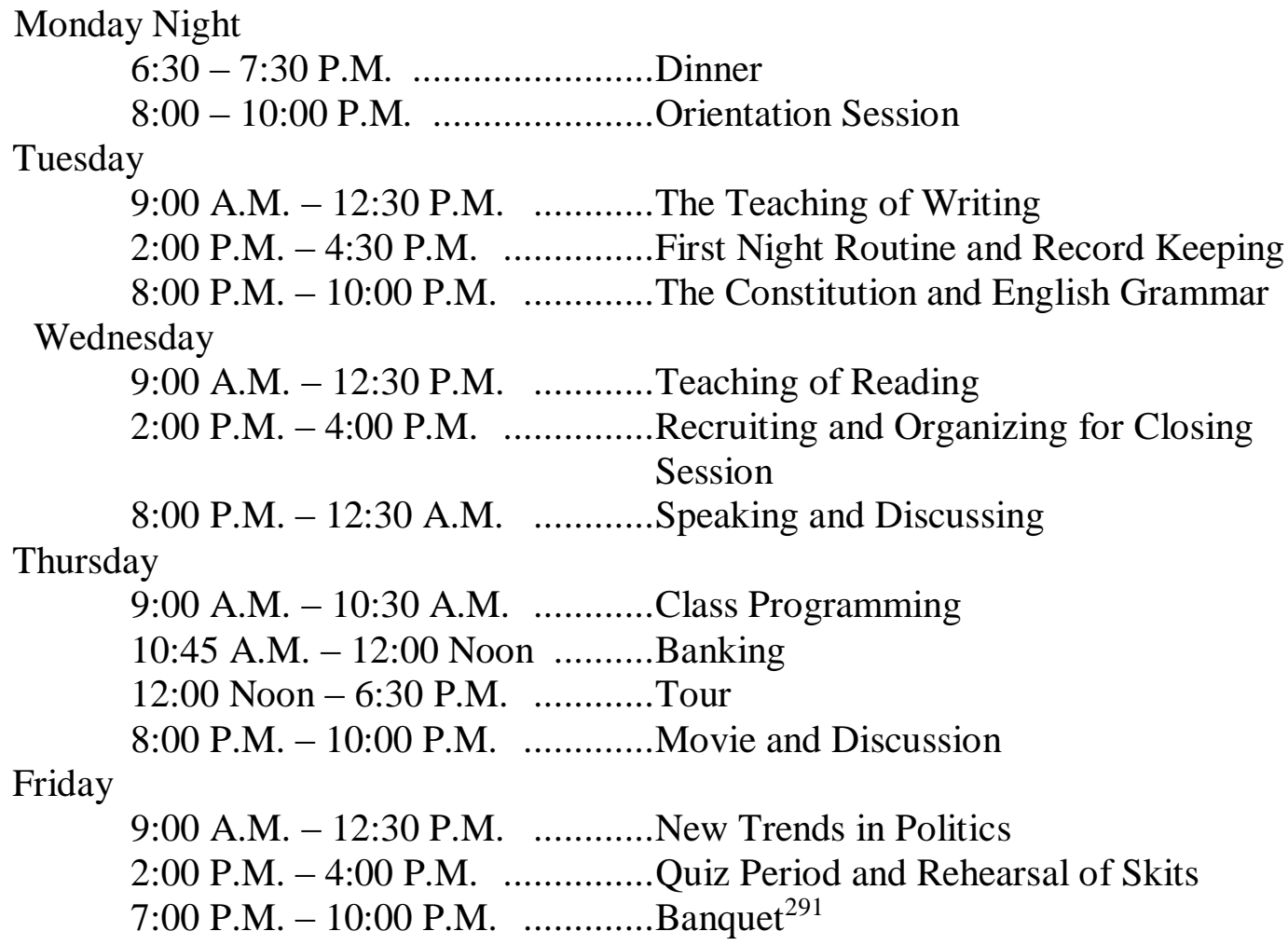

\footnotetext{
288 Cotton, If Your Back's Not Bent, 112.

289 Ibid., 115.

290 Clark, Echo in My Soul, 182.

291 SCLC, "The Test," KPKC, 136:30.
} 
During the orientation session, the CEP teachers would ask their students what they wanted to learn. Robinson found that illiterate students usually wanted to learn to read the Bible and election laws related to registering to vote, to write their names and bank checks, and to fill out order forms and social security applications. ${ }^{292}$ So Clark would ask the students to read meaningful words such as constitution, and if they could read the words, then she taught them how to spell them. When the students could write the words, Clark had them discuss what they meant. ${ }^{293}$ Clark's method formed the foundation for how students were taught reading, writing, and grammar. Teachers of the CEP's five-day workshops taught reading and writing in the way shown below:

Use of Words

Take a meaningful word for a reading lesson.

Help class pronounce it (use sound chart).

Help class learn to spell it.

Discuss its meaning and uses-Use dictionary last.

Example:

1. Citizen

What makes a citizen?

Who is a citizen?

What does dictionary say?

What does $14^{\text {th }}$ Amendment say?

(Have someone read definition and someone read $14^{\text {th }}$ Amendment)

Discuss

2. Legislature

What is it?

Do we have one in our state?

How are the members selected?

From what area do they come?

When do they meet? Where?

What do they do?

Do you know any names?

What positions do they take?

Discuss $^{294}$

Thus, the CEP teachers taught students how to read and write using words that were closely connected to the social issues of their local African American community. When they

292 Clark, Echo in My Soul, 147; and Ready from Within, 50.

${ }^{293}$ Clark, Ready from Within, 64.

294 SCLC, "The Test," KPKC, 136:30. 
discussed these meaningful words, the teachers of the CEP teacher training workshop could teach why students had to vote for their own rights and for solutions to the problems of their community. They taught students how to pronounce and define the words and encouraged them to make sentences from each word and discuss each word's meaning. The following are a few of the words: "Larceny, Commissioner, Register, Congressman, Bona Fide, Affidavit, Signature, Elector, Residence, Applicant, Precinct, Citizen, Resident, Recruit, Citizenship, Registration, Modern, Secretary, Representative, Certificates, Authority, Authoritative, Valid and Amendment." 295

The CEP five-day workshop taught people how to complete money orders and how to write letters to businesses. They also discussed when the students needed to use money orders. These sentences were used for discussion during the workshop:

Sometimes I need to get some money from the bank.

I get a blank check at the desk in the bank.

Then I write a check for the money.

I write the month, the day of the month, and the year.

Then I write the name of the person who gets the check.

Then I write the amount of the check in figures.

Next I spell out the amount of the check.

Then I sign my name at the bottom of the check.

Sometimes I write a check at home.

Sometimes Mary writes checks.

Mary signs her name to the checks she writes.

I sign my name to the ones I writes. ${ }^{296}$

The CEP provided samples of a money order form and a bank check, so the students could practice how to fill out these forms. ${ }^{297}$ Moreover, when the students needed to write bank checks and money orders, they needed to know arithmetic. The CEP taught arithmetic from a beginner's level to an advanced level. Based on the success of the CEP, teaching arithmetic

\footnotetext{
295 Ibid.

296 Ibid.

297 See Appendix B.
} 
in citizenship schools became popular in the voting education schools of other organizations, such as SNCC.

For the letter-writing session, the CEP teachers encouraged their students to discuss reasons why they needed to know how to write a letter and what its uses were:

\section{Letter Writing}

1. Discuss reasons for knowing how to write a letter (Take care of business matters, stay in touch with friends, etc.). It is more effective if your letter says exactly what you mean and if it looks good.

2. Make teachers aware of where the five parts are placed.
a. business letter
b. friendly letter

3. Have pupils bring in letter showing form used.
a. discuss these.
b. get students reactions.
c. turn to authorities in English as a last resort.
d. observe punctuation in both forms.
e. write a letter that you have been wanting to write. ${ }^{298}$

In terms of getting social security account, the CEP teachers reminded their students

what the benefits of social security were and then taught them how to apply for a social security account at their nearest district office:

\section{Social Security}

This passage can be the introduction to a workshop on social security. For discussion purposes, ask the class what they think of social security. If you have persons in their 60 s in your group, this should arouse much interest.

1. Read, or have a student read the passage in the workbook.

2. Have someone find out how the program began.

3. Have someone find out where the office is.

4. Invite a representative from the office to speak to your class on the subject. (They will show a film and answer questions free of charge.) Have class invite their friends in. 299

There were diverse discussions during the five-day workshop about the responsibilities of the citizenship school teachers and about the experience of running adult education classes in the local community. Through these discussions, the CEP staff members

298 SCLC, “The Test," KPKC, 136:30.

299 Ibid. 
could meet the specific needs of local leaders and analyze the outcomes of local voting rights classes. Below are lists of the responsibilities of teachers and supervisors.

The Responsibilities of the Teacher Are:

1. To teach the class;

2. To decide (with the help of the supervisor) what kinds and what quantities of educational material are needed;

3. To assist his students in the community activities which will be carried on throughout the year;

4. To assist the supervisor in recruiting (if necessary).

The Responsibilities of the Supervisor Are:

1. To recruit students for classes;

2. To arrange places for schools to meet;

3. To organize the schools in his area;

4. To help the teacher decide upon material and equipment and the quantities needed;

5. To advise teachers on class programs and community activities;

6. To visit classes and supervise the work of teachers;

7. To coordinate the work of the area;

8. To plan the time of the year with the teacher (seasons when students are least busy on jobs).

The supervisor will be expected to attend, with the teachers in his area, a oneweek training workshop and a weekend refresher workshop, the latter being scheduled within a reasonable length of time after his Citizenship Schools are underway. ${ }^{300}$

As this statement demonstrates, the CEP kept close contact with the diverse circumstances of its teacher-students in order to learn about and examine their social problems. The CEP teachers and supervisors could share their experiences and feedback about their local citizenship schools; thus, they could develop the benefits of the workshops and solve the problems of the workshops together. The following are a few of the questions workshop teachers and supervisors were asked to respond to: "What were some of your problems in getting the Citizenship School Program started in your community?" "What were the

300 Ibid. 
problems of operation?" "What were some of the problems you had in getting along with your co-workers?" "Please list any other kinds of problems."301

After the five-day workshop, the teachers and supervisors gave each student a questionnaire, and the students returned their answers to SCLC. One of the questions posed to the students was, "Has the student become a registered voter?"302 The teachers and supervisors requested that their students report if there were any problems with registering to vote related to reading and writing. The CEP also double-checked with its students if they could participate in any election or referendum, and it asked them to describe why they chose the candidates for whom they voted. Moreover, the students of the CEP were asked how many people they could help if they could help other people vote and what kinds of civic actions they could participate in. The students were requested to report their civic actions such as "signing petitions, attending community meetings, engaging in demonstrations, making talks and service on committees to negotiate with policy making boards." 303 One question asked if they could make their community actions more effective. If they could, the students were expected to state which social organizations they participated in and if they could hold any office in the organization and take any responsibilities for the community. The CEP also asked its students if they could contribute to their communities through unselfish services such as "blood for blood bank and volunteer hours service at the polls."304 They were also questioned about whether they could improve their social and personal attitudes by doing such things as "arranging car pools, being cooperative, helping neighbors, telephoning and seeking aid for the sick and afflicted." ${ }^{305}$ These questions demonstrate how

$\begin{array}{ll}301 & \text { Ibid. } \\ 302 & \text { Ibid. } \\ 303 & \text { Ibid. } \\ 304 & \text { Ibid. } \\ 305 & \text { Ibid. }\end{array}$ 
the CEP became involved in the situation of each of its students. Training individuals was a very different tactic from the mass movements on which SCLC had been working.

Watching films was an accessible learning method for workshop students who were not fluent in reading and writing. The CEP workshop had the following films: "A Citizen Participates," "A Citizen Makes a Decision," "Christian Citizenship," "Discussion in Democracy," "Star of Bethlehem," "Unto Thyself Be True," "What It Means to Be an American," "Voting Procedures," "Our Town Is the World," "The House I Live In," "Government Is Your Business," "Knock on Every Door," "Mississippi Story," and "The Nashville Sit-In Story." ${ }^{306}$ Most of these films were about twenty minutes in length, and their narratives were generally easy to understand. The films highlighted the individual rights and freedoms of American citizens and explained how to use these rights of citizenship in American society. Except for "Mississippi Story" and "The Nashville Sit-In Story," most of the films did not focus on the racial problems of American society. Rather, the films dealt with awareness of political rights, and they highlighted the assimilation of diverse races and religions into American culture, the "melting pot." The foci of these films coincided with the CEP's philosophy, which stressed individual decision making and racial assimilation. The CEP's Citizenship School Workshop

The CEP's Citizenship School workshop was an adult school which provided the basic education and information students needed to become registered to vote. The Citizenship School workshop had between twenty-five and thirty-five students in each class. Each workshop consisted of one or more classes, depending on the number of enrolled students, and was located in a given area covering one or two counties, as determined by the

306 SCLC, “Reports to Foundation,” May 1962-January 1963, KPKC, 136:29. 
CEP. ${ }^{307}$ This was the major grassroots workshop program of the CEP and the main effort of the HFS. After she had run citizenship schools in various Southern areas, Clark realized that the average Southern adult student was required to study eighty hours through the HFS's program in order to become a qualified voter. ${ }^{308}$ The workshop program usually took three or five months. If the workshop was scheduled for a three-month session, the students would meet two evenings a week for a two-hour class each evening, along with additional weekend workshops and outdoor sessions. ${ }^{309}$ After the students completed the Citizenship School program, they received a certificate of completion signed by Martin Luther King, Jr., the president of SCLC.

The program of the CEP's Citizenship School was similar to that of the five-day workshop. However, while the five-day workshop was an intensive session that focused on discussing the work of the teachers and supervisors, the Citizenship School started with the beginner's level of learning. There were diverse versions of the Citizenship School workbook; however, they commonly had a section about choosing meaningful words and discussing their meanings. The Citizenship School workbook also had a "Sound Chart" used to teach the sounds of the letters of the alphabet. ${ }^{310}$ Clark recommended that Citizenship School teachers begin their workshops by teaching the following:

Our America:

This is a map of the United States of America. It is the home of a great American nation. We are a part of that great nation. We are all Americans.

Our home is on islands in the Atlantic Ocean in Charleston County on the southeast coast of South Carolina. ${ }^{311}$

We love this great land. It has given us our living for many years. It holds opportunities for our children and grandchildren.

307 Highlander Folk School, "Proposed Citizenship School Training Program," December 1960, KPKC, 136:9. This document is a report from the HFS that describes the contents of the HFS's Citizenship School adopted by the CEP.

308 Clark, Echo in My Soul, 195.

309 Myles Horton, "Memorandum On: Citizenship School Training Program," December 1960, HFS Archives.

310 See Appendix C.

311 The names of the county and state depended on the location of the Citizenship School. 
Day by day we silently pour the concrete of love into the furious violent ocean of hate. Some day that concrete will build a foundation that will support a bridge to span the channel and open lines of communication to all peoples.

Our hearts are filled with that spirit of brotherhood and our hands move forward defying all acts of violence. The Supreme Court building and its justices are the symbol of law. The White House is the symbol of the free representative government. We accept the results of election and abide by ruling of the courts. We in America know that an educated child is more important to the future than any man's political future.

The voice of the school child can be heard asking, "What about me?"

The American way is law and justice.

Yes, we love this great land-America! ${ }^{312}$

This statement on "Our America" describes well Clark's philosophy of integration as one of the civil rights goals that she had fought over forty years to gain for African Americans.

There was also "The Purpose of the Citizenship School" in the beginning part of the workbook:

The Citizenship Schools are for adults. Their immediate program is literacy. They enable students to pass literacy tests for voting. There is also involved in the mechanics of learning to read and write an all-around education in community development which includes housing, recreation, health, and improved home life... The Citizenship Schools provide a service to the people which is not available through any other private or public program at the present time. They are open to all people of a community who face problems related to first-class citizenship and want to do something about them. ${ }^{313}$

This statement of purpose was very persuasive for local disenfranchised people because it dealt with the practical issues of their lives in society, not just with the problems related to voting. The citizenship schools taught local people practical ways to improve their lives and gave them multiple steps to take to better their life circumstances after gaining their voting rights.

The next step in the Citizenship School was learning the state's election laws and how to fill out the registration certificate and voting application forms. The CEP provided copies

312 Clark, Echo in My Soul, 199.

313 SCLC, "SCLC Citizenship Workbook," KPKC, 153:23. 
of registration certificates and applications for practice. ${ }^{314}$ For instance, the Citizenship

School program in Tennessee taught the students the Tennessee requirements for registration and voting.

Registration Requirements:

1. You must be 21 years of age.

2. You must have been a resident of the state for one year.

3. You must have been a resident of the county for three months.

4. You must register at the office of registration before the books are closed (This deadline will vary depending upon the county of which you are a resident).

5. You must answer half a dozen simple questions.

6. You must sign your name twice.

7. If you are already a registered voter but have not voted in a state-wide election in the past four years, your name will be dropped from the registration roll and you will have to re-register.

8. If you are already a registered voter but have moved to a new address in the same county, you must inform the registration office. You do not have to go to the office in person. Write the new address on the reverse of your family's registration cards, sign your name and mail them to the office.

9. If you are already a registered voter but have moved to a new county, you must re-register.

The deadline for registering to vote in my county is (date)

The registration office in my county is at (address)

It is open from 8:30 A.M. to 5:00 P.M. The Benefits:

1. Cast your ballot in the primary elections.

2. Vote in the county, state, and national elections.

3. Help choose the president of the United States. ${ }^{315}$

After learning the registration and voting requirements, students had to become

familiar with the questions their state would require them to answer. In the case of the state of Georgia, there were thirty questions that had to be answered in order to pass the literacy exam for voting. The CEP workshop in Georgia reminded the students and explained, "One who cannot read and write must answer 20 of these questions to register." ${ }^{316}$ The questions were difficult, as many state officeholders wanted to make them as difficult to answer as they

314 Clark, Echo in My Soul, 201.

315 SCLC, "My Citizenship Booklet," 1961-1962, HFS Archives.

316 Clark, Echo in My Soul, 202. 
could. ${ }^{317}$ There were differing numbers of questions and question sets that were required to pass literacy exams in the Southern states. For example, the Citizenship School in Jefferson County, Alabama, taught twenty-two sample questions and answers. The CEP students of Jefferson County had to know the requirements for voting, the names of the senators and the number of representatives from the state of Alabama in Congress, the number of representatives in the House of Representatives, the names of the city commissioners, the name of the chief of police, and the name of the county sheriff. ${ }^{318}$ These difficult questions and answers had to be memorized by African Americans who needed to pass the literacy exam to vote. Since the literacy exam required intensive learning on the part of uneducated people, the CEP leaders chose not only to fight to abolish the segregation of voting rights, but to educate illiterate people. After the passage of the Voting Rights Act of 1965, the CEP did not stop teaching uneducated people in local areas. These continuous efforts of the CEP testify that the major target of the Citizenship School program was to educate grassroots people about their civil rights because they were segregated not only by Jim Crow laws but also by "American-style apartheid." 319

In the Citizenship School classes, students learned how to write friendly letters and business letters. This included learning how to address officials in letters-for example, "My Dear Mr. President" or "Dear Senator or Congressman"—and that "letters to all officials close with 'Respectfully yours,'."320 As part of the five-day workshop, the Citizenship School students learned how to fill out application forms for social security numbers, how to write bank checks, and how to get money orders. There were sessions for learning beginning and advanced arithmetic. The students were also taught good manners and social skills, such

\footnotetext{
317 Ibid., 203.

318 State of Alabama, "The Registration Process," KPKC, 138:8. For all twenty-two questions and answers, see Appendix E.

319 Cotton, If Your Back's Not Bent, 117.

${ }^{320}$ Clark, Echo in My Soul, 200.
} 
as not to interrupt someone who is talking and how to respect another person's interests in conversation. This included a session called "Be Polite," which taught students how to introduce a new friend to their other friends. ${ }^{321}$ The students were encouraged to introduce women and older people first.

Another session covered the history of SCLC. Mostly, the CEP taught how SCLC began its fight against segregated voting rights and the story of the Montgomery Bus Boycott. The CEP also introduced students to SCLC's two major foci: “the use of a non-violent philosophy as a means of creative protest, and securing the right of the ballot for every citizen." ${ }^{322}$ A session on "The Bible and the Ballot" introduced students to Jesus' words in Luke 4:18:

The first words of Jesus' public ministry were:

"The spirit of the Lord is upon me,

Because he has anointed me to preach

Good news to the poor.

He has sent me to proclaim release to the captives . . .

To set at liberty those who are oppressed,

To proclaim the acceptable year of the Lord." 323

The CEP leaders understood that Jesus had anointed them to carry out this same mission:

"this was Jesus' work and now it is ours." "324 They believed they should free oppressed and segregated people just as Jesus had. The CEP leaders taught that the Citizenship School was a declaration of Jesus' work to learn to live as "all God's children together in peace and justice." 325 The CEP insisted that the Fifteenth Amendment, passed in 1870, had secured everyone's voting rights, regardless of race. ${ }^{326}$ Thus, the segregation of voting rights was

321 SCLC, "My Citizenship Booklet," 1961-1962, HFS Archives.

322 SCLC, "SCLC Citizenship Workbook," KPKC, 153:23.

323 Ibid., 29.

324 Ibid.

325 Ibid.

326 Ibid. 
unjust, and the election system provided the people of Jesus their best chance to change the evil systems of their society. As the Lord's Prayer proclaims, the CEP teachers believed,

This world can be more like God's Kingdom if men will learn to care for the poor and needy: if we can help to feed the hungry in other lands and ours; if each is concerned about the well-being of his neighbor and if each votes for persons who share these same human ideals. The ballot is in our hands, to vote for good for all mankind. ${ }^{327}$

For discussions about the Christian faith and the teachings of the Bible in relation to voting rights, the following questions were used:

1. What would happen in your community if faith in God was put aside and violence took over?

2. If you are not registered to vote, do you think you are doing justice to yourself and your fellow man?

3. We have a task which Jesus himself set before us, how can we best accomplish this work $?^{328}$

The CEP teachers also introduced freedom songs to the students, such as "We Shall Overcome," "Keep Your Eyes on the Prize," “Oh Freedom," “The Hammer Song," "Woke up This Morning," "Wade in the Water," "Done Made My Vow to Be Free," "Didn’t My Lord Deliver Daniel?" and "We Are Soldiers in the Army." 329 Along with teaching these spirituals, the CEP teachers explained the history of slavery from 1619 onward, and they shared the stories of freedom fighters such as Crispus Attucks, Benjamin Banneker, Mary McCleod Bethune, Harriet Tubman, and Sojourner Truth. ${ }^{330}$ The CEP's teaching of the history of African Americans highlighted their human rights and freedoms as the sources of their protests. Interestingly, there was a story in the CEP's Citizenship School workbook about white people who helped with the freedom struggles of African Americans. The CEP described Crispus Attucks as the first man who died for the freedom of this country. ${ }^{331}$ In the CEP's workbook, Attucks was designated a major person involved in the initiation of the

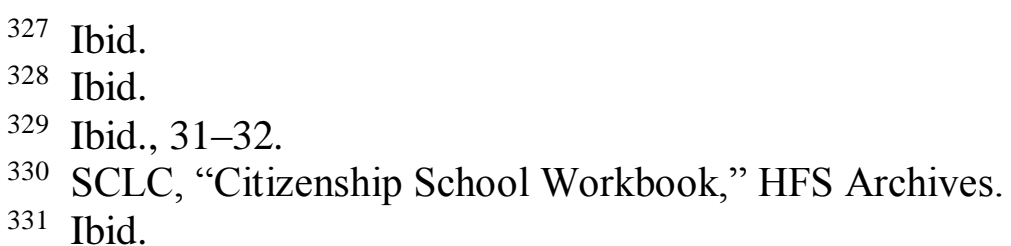


American Revolution, and Truth was depicted as a person who actively worked for the wellbeing of wounded soldiers and the freedom of African Americans during the Civil War. ${ }^{332}$ The CEP taught students that, even though African Americans were enslaved, key figures among them had independently fought for their own freedom and rights over the course of American history.

\section{The Refresher Workshop}

The refresher workshop, which was called "advanced training," was for the CEP's training leaders who worked as the teachers and supervisors of the citizenship schools. The CEP usually had one refresher workshop each month, which consisted of a three-day program. The program began on Thursday with dinner and "Singing, Introductions, Reports from the Field." 333 The CEP teachers and supervisors would report their accomplishments, highlighting the development of their students' knowledge and participation in community activities. They would examine together:

1) membership and participation in civic organizations

2) participation in bi-racial community activities and programs

3) participation in picketing, boycotts, and selective buying programs

4) participation in any national, state or local elections held during the past few weeks. ${ }^{334}$

These guidelines demonstrate the essential objectives of the CEP, which was not only concerned with participants' voting rights issues but also sought to increase the local power of the mass movements of other organizations, including racial integration movements and other civil rights movements. From its initial year, the CEP focused on educating people about the following subjects in addition to voting rights: "direct action, nonviolence, civil disobedience, picketing, publicity, boycotting, prejudices and segregation and cultural 
programs, etc.”335 The expandability of the CEP was proved by the mass movements of the Selma to Montgomery marches and the Mississippi Summer Project, which were led by graduates of the CEP. ${ }^{336}$

Activities on Friday and Saturday included discussion sessions about initiating citizenship schools, recruiting and finding places for the schools, creating workshop schedules, and overcoming the opposition of people in the community. The CEP teachers and supervisors also talked about making and developing text materials, keeping records, grouping the different levels of students, special problems, and using audiovisual materials. ${ }^{337}$ For the last session, the attendees watched a film that sparked discussion of the individual responsibilities of citizens and the effectiveness of using certain teaching materials in the local citizenship schools. Finally, they determined and analyzed what they could do to improve the individual responsibilities and rights of the citizenship school students and to help initiate and maintain the local citizenship schools. ${ }^{338}$ As the activities of the refresher workshop demonstrate, the CEP's methods of discussing, analyzing, and analyzingpracticing-discussing strengthened the independent and community power of the local citizenship schools.

\section{The CEP People: The Grassroots Leaders from the CEP}

Clark and Horton said, “The success of the Citizenship School plan depends on three factors, speed, effective performance, and nominal cost." 339 The success of the CEP's Citizenship School can be contributed to the Field Foundation's grant, which covered the school's nominal costs, and to its staff leaders and teachers, who were motivated and quickly

\footnotetext{
335 James R. Wood, “Proposed Citizenship School Training Program,” January 20, 1961, $\mathrm{KPKC}, 136: 27$.

${ }^{336}$ For the involvement of the CEP graduates in the major mass movements of the civil rights movement, see the following pages.

337 SCLC, "Citizenship School Workbook," HFS Archives.

338 Ibid.

339 "Memorandum on Citizenship Program," June 26, 1961, KPKC, 136:16. 
expanded the Citizenship School program until it had a Southern-wide impact. The CEP acted behind the scenes of the Selma to Montgomery marches, the Freedom Rides, and the sit-ins, which were led by young people and grassroots civil rights leaders. This chapter analyzes how the CEP challenged young leaders to expand and develop the tactics of the civil rights movement and to increase the participation of people at the grass roots. Through grassroots tactics, the CEP founders broke the mold of the old leadership style, which had depended on charismatic leaders, and it opened a new era for the civil rights movement, which shared leadership with common people who were awakened to work for their own rights. From the CEP's initial year of 1960, its founders followed their detailed plans for training new young leaders to pioneer the way for local people to stand up for their civil rights.

\section{Job Descriptions and Actions of the Major Leaders of the CEP}

Rev. Andrew J. Young worked for the CEP from 1961 to 1964 as its executive secretary. His primary responsibility was preparing the CEP's budget. Young's contribution to making the budget of the CEP independent was crucial to its operations. It allowed the CEP to hire Clark, Cotton, Ponder, and Robinson, who were the essential supervisors of the CEP, and to set up its headquarters, the Dorchester Center. Young needed to maintain connections between the Field Foundation, the American Missionary Association, and SCLC, all of which had organizational authorities to supervise the financial expenditures of the CEP. ${ }^{340}$ Young had to contact the administrators of the American Missionary Association and the Field Foundation many times to negotiate compromises regarding the finances of the CEP. In a letter to Maxwell Hahn of the Field Foundation, Young said,

May I suggest that the Field Foundation consider a three to five year commitment to this program, with an annual review of the budget in the light of

340 Andrew J. Young et al., "Annual Report: Citizenship Education Program sponsored by Southern Christian Leadership Conference, American Missionary Association 1963-1964," KPKC, 137:3. 
the previous year's results and the anticipated demands of the future. ${ }^{341}$

Young had to weave the strategy of the Citizenship School program according to the current situation of the CEP. He determined what areas the CEP needed to concentrate on and how to make the program of the CEP cooperate with and blend into the larger arena of the civil rights movement. ${ }^{342}$

As a pastor, Young also enlarged the philosophy of the CEP by adding Christian thinking that supported the civil rights of African Americans. The program and major philosophy were created and developed by Clark, and Young asked Clark what he had to do as the executive secretary of the CEP. In his first year at the CEP, Young sent a letter to Clark asking for guidance:

I agreed to take over the responsibility for this blindly, for even though I don't know very much about the program's operation, I am convinced that it is one of the most important things being done in the world today. I also have a great deal of confidence in the people related to it, namely you and Myles, plus Dr. King and others who have responded to it. I don't realize the full implications of my job as yet, but I want to be able to depend on you to help me discover them. There are perhaps some ways that I can make your jobs easier and also add to the effectiveness of the total work. ${ }^{343}$

As Young indicates, Clark guided the CEP staff in the development of the Citizenship School program. Even though he had previously been unfamiliar with the program, Young learned quickly, so he was able to supervise the program and develop its philosophy of grassroots leadership into a Christian movement of SCLC. ${ }^{344}$

Due to the influence of the CEP program through Clark and of his Congregational church background, Young was able to function as a liaison between the male pastoral leaders of SCLC and the female civil rights veterans who had joined with SCLC, unlike its senior leaders - King, Abernathy, and Walker-who were accustomed to the male

\footnotetext{
341 Young to Hahn, February 13, 1963, KPKC, 136:6.

342 Young et al., "Annual Report."

343 Young to Clark, Summer 1961, KPKC, 136:10.

344 See the following pages for more about Young's contributions to the philosophy of the Citizenship School.
} 
chauvinism of the Southern Baptist tradition. ${ }^{345}$ Young's work as a liaison through the CEP demonstrates that the program contributed to the dismantling of the hierarchical leadership of the male pastors in SCLC and to the establishment of the new leadership of women, young college students, and local people. ${ }^{346}$

Young had the responsibility of negotiating and developing the support system of the CEP for its local affiliates. Through this work, Young was able to establish a communitywide citizenship program. Young took over the affiliates of the HFS's Citizenship School from Horton and Clark and supervised and supported the local affiliates under SCLC's CEP. ${ }^{347}$ He also connected the CEP's support system with other organizations that had already established voting education programs in local areas. ${ }^{348}$ In addition, it was Young's responsibility to secure and apportion the CEP's financial resources, based on his research into the socioeconomic situations of the local citizenship schools, and to fundraise for the CEP's financial needs that went beyond the grant funding provided by the Field Foundation. ${ }^{349}$ As its executive secretary, Young had to supervise all the financial resources of the CEP. His other duties included teaching about political action and counseling the students at the Dorchester Center, and he coordinated the staff members of the CEP and prepared materials for CEP classes. ${ }^{350}$ Importantly, Young had to give speeches and publish writings as an ambassador of the CEP "throughout the nation." 351 Young did a lot of writing and speech-giving throughout the civil rights movement era in order to pass along the

345 Young, An Easy Burden, 139.

346 The new leadership of SCLC was developed by the local leaders of the CEP, such as Hosea Williams, Diane Nash, and James Bevel. See the following pages.

347 For more about the affiliates of the CEP, see the following pages.

348 Young et al., "Annual Report," 17.

349 Ibid.

350 Ibid.

351 Ibid. According to his CEP job description, Young had to share the CEP program "throughout the nation," but he delivered the messages of the CEP not only to the nation but also to the world as an agent of the World Council of Churches. See the following pages. 
implications of the CEP's voting rights movement and to convey the Christian values of this movement. Thus, Young contributed to the spread and development of the CEP across the South, and he introduced this program's results to the people of the world.

Clark worked for the CEP as its supervisor of teacher training from its beginning. She introduced the HFS's Citizenship School program and trained all of the CEP leaders in the original tactics of this program. Clark was responsible for greeting all the students when they arrived at the Dorchester Center, and she supervised their welfare while they stayed at the center, especially the provision of meals and housing. ${ }^{352}$ She had to arrange the places for session meetings and plan the opening session of the Citizenship School. She also taught classes and arranged staff meetings. In the field, Clark had the responsibility of visiting the local teachers of the citizenship schools and helping them organize and improve their classes. $^{353}$ She held meetings of teachers, students, and field supervisors according to their districts, and she supervised the workshops for experienced teachers to help them adapt their new classes to the needs of their communities. ${ }^{354}$ Clark's tasks included counseling community leaders and negotiating their power structures when they had trouble conducting the citizenship schools. ${ }^{355}$ She needed to teach special classes to awaken local citizens to their rights, so they could ask their local government officials to improve the public welfare by doing such things as "paving a street, having garbage collected, fixing a road or spraying weeds as well as [having] a housing code or health service available." 356

In her office at the CEP, Clark was responsible for writing and responding to letters and for approving vouchers for the CEP's expenditures. ${ }^{357}$ She had to arrange speakers for

\footnotetext{
352 Young et al., "Annual Report," 18.

353 Ibid.

354 Ibid.

355 Ibid.

356 Ibid.

357 Ibid.
} 
class sessions and take charge of visitors to the CEP. Clark was constantly developing new materials for the CEP program, and she had the responsibility of writing articles on and reports of the CEP's work in the diverse regions of the South. ${ }^{358}$ Clark also published a monthly newsletter that covered the CEP's achievements and how this program had impacted the lives of local people in the South. Since she was able to transfer the methods and philosophy of the HFS's Citizenship School to the CEP, Clark testified, "I am very much at home in my work with SCLC." 359 In the same way that Young negotiated with the hierarchical leaders of SCLC to open them up to a different leadership approach, Clark—as a veteran, sixty-plus-year-old female civil rights leader-challenged SCLC to invite women, young people, and grassroots leaders into SCLC's leadership of the civil rights movement.

Clark was an executive staff member of SCLC; however, she testified that Abernathy doubted her position on SCLC executive board. ${ }^{360}$ Moreover, even though King believed in her ability to make the voting rights movement nationwide, he rejected the American Friends Service Committee's request to have Clark deliver public speeches at King's reception of the Nobel Peace Prize. ${ }^{361}$ King also ignored Clark's advice that other leaders could make speeches instead of him and that King did not need to lead every march, because she was concerned SCLC would depend too much on him. ${ }^{362}$ Clark recognized that the reason why SCLC leaders ignored women's suggestions was because the older women activists' advicegiving reminded them of their mothers' control over them. ${ }^{363}$ Clark later recalled that Esau Jenkins used to ignore women's voices too. ${ }^{364}$ From this experience, Clark resisted this tendency toward male chauvinism among the civil rights leaders, and she engaged in "the

\footnotetext{
358 Ibid.

359 Clark, Echo in My Soul, 216.

360 Clark, Ready from Within, 77.

361 Ibid.

362 Ibid.

363 Ibid., 79.

364 Ibid.
} 
women's liberation movement" within the civil rights movement. ${ }^{365}$ Through her classes at the HFS, Clark encouraged Rosa Parks and Virginia Durr, who supported the Montgomery Bus Boycott, and SNCC leaders to raise up their voices in the civil rights movement. She testified that the Prayer Pilgrimage was organized by women. ${ }^{366}$ As she did in the cases of Parks and Durr, Clark introduced many young grassroots leaders and women leaders who were trained by the CEP, such as Hamer and Nash, to SCLC leaders. Her contribution to developing grassroots leaders changed SCLC's male clerical leadership, which had been dependent on the existing leaders of affiliated organizations.

When the students' sit-ins received national attention, Clark reminded SCLC people to consider the movement "the most important development in the southern struggle." 367 She pointed out the effectiveness of the sit-in movement, which strongly opposed any type of segregation in society. Before the CEP was officially initiated, Clark organized a college workshop held November 11-13, 1960. In attendance were students from fourteen colleges, including the University of Texas, the American Baptist Theological Seminary, and Vanderbilt University. ${ }^{368}$ These colleges had most of the students who were part of the sit-in movement, and the workshop was racially integrated. This workshop is evidence that Clark trained the young students who founded SNCC and led the sin-ins, thus becoming the new leaders of the voting rights movement. Clark fully agreed with King's Christian philosophy of nonviolence and beloved community, and she implemented this philosophy in the CEP's programming. ${ }^{369}$ Through the Southern-wide success of the CEP, she was the essential person who set up the "two principal focal points" of SCLC: nonviolent resistance against

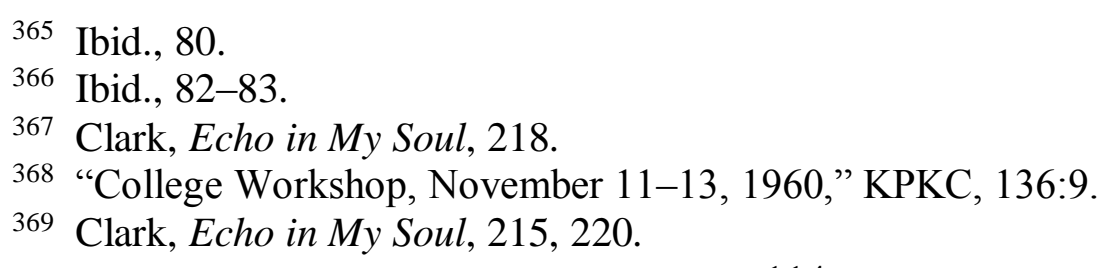


social injustice and the full citizenship of every citizen. ${ }^{370}$ In order to build beloved community, Clark insisted that CEP leaders should live in their trainees' communities at least a month, so they could visit their neighbors and churches. ${ }^{371}$ Clark herself lived in Huntsville, Alabama, to examine the achievements of the local CEP classes. ${ }^{372}$

Dorothy Cotton worked for the CEP as an educational consultant. Her major responsibility was training teachers through the five-day workshop at the Dorchester Center every month. ${ }^{373}$ According to Cotton, her major classes were

the art of teaching writing; teaching of the U.S. Constitution; basic English grammar; the art of recruiting adults for local classes; demonstration of uses of teaching aids such as: film-specifically showing how small group discussions resulting therefrom can induce learning; presentation of important new developments to study as, recently, the Civil Rights Bill; reviewing the week's work. Most important in all of these classes is the emphasis placed on teaching methods since our aim is to make teachers out of adults who, more often than not, have only a high school education or less. (The Socratic Method and/or T [Training] Group Philosophy provide my particular orientation, coupled with the special motivation to help Negroes help themselves and move into the mainstream of American life. ${ }^{374}$

Cotton's teacher training classes were developed in accordance with the students' understanding of the social value of voting rights. The level of these classes demonstrates that the CEP developed the philosophy of grassroots leadership much more than the public speeches of the mass movements.

Cotton prepared teaching materials for the CEP classes and attended teachers' meetings in local areas. ${ }^{375}$ Cotton would lead the teachers to discuss their development and assess their advancement, and she would motivate them to come up with new areas for developing their communities. ${ }^{376}$ When she was working in her office, Cotton answered

\footnotetext{
370 Ibid., 215.

371 Ibid., 222.

372 Ibid.

373 Young et al., “Annual Report,” 19.

374 Ibid.

375 Ibid.

376 Ibid.
} 
letters from teachers and explained the CEP's structure and activities to visitors. ${ }^{377}$ Cotton was tasked with writing reports about the achievements of the local citizenship schools and with evaluating the CEP teachers and supervisors. ${ }^{378}$ In the field, Cotton worked in local communities on special projects that had resulted from the citizenship schools. These special projects were mostly direct actions resisting segregation, and Cotton had to interpret the actions in terms of seeking social equality. ${ }^{379}$ Clark, Cotton, and Young would visit local people to share their experiences and to supervise the training of local leaders. ${ }^{380}$ Through inviting people by phone and by making announcements at church meetings, Cotton recruited local people to join the CEP's five-day workshops. ${ }^{381}$

Cotton had a deep understanding of the gender leadership struggle in SCLC. She had been working closely with Walker and King because she had a Baptist church background, but during her SCLC years, she shared in the women leaders' struggle with male chauvinism through working with Baker and Clark. ${ }^{382}$ Cotton experienced the sexism of SCLC's Southern Baptist male clerical leaders; however, she maintained a balance in her relationships with the male leaders, such as King and Walker, who partly respected her work in SCLC by giving her an unequal leadership position, and with the women leaders, who had worked with her to develop the grassroots leaders. Cotton combined the effectiveness of the male leaders, who could appeal to church connections and their audiences' familiarity with male clerical speakers during that time, and the female leaders, who were well equipped to establish the leadership of ordinary people. By maintaining this balance, Cotton was able to have a close relationship with both King and the women leaders of SCLC.

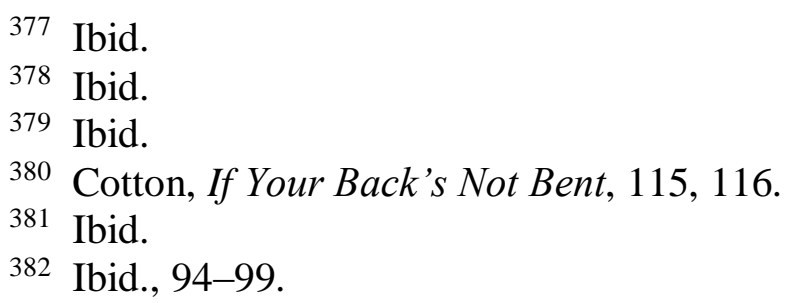


Cotton loved to sing many songs while she trained students in the CEP workshops and when she led civil rights actions. Clark introduced CEP students to soulful songs from her HFS years that would inspire them to overcome the struggles resulting from segregation. Clark had put together a booklet called Songs for Freedom when she was working for the HFS, and she transferred the use of this booklet to the CEP. ${ }^{383}$

The first CEP five-day workshop graduate, Fannie Lou Hamer, contributed to the spread of the freedom songs of the civil rights movement nationwide. Clark and Cotton had begun that first workshop by singing freedom songs, and Hamer had shared the spirituals and "sorrow songs" that she had learned on a Mississippi plantation. ${ }^{384}$ Cotton discovered Hamer's powerful voice for freedom—she was "sick and tired of being sick and tired" because of segregation - through her soulful songs, such as "This Little Light of Mine" and "I've Been in the Storm So Long." "385 Hamer gained nationwide attention through her broadcasted testimony to the Credentials Committee at the Democratic National Convention and through singing songs and witnessing during the Freedom Summer. Before and after she attended the CEP workshop, Hamer experienced terrible racist attacks and jailer brutality while trying to register herself and others to vote, and her testimonies about this brutality became a powerful weapon for desegregating voting rights. Hamer's songs and testimonies were based on her experience of sharing in the CEP workshop, and Cotton and other CEP teachers contributed to Hamer's nationwide success as a grassroots leader for voting rights. ${ }^{386}$ Through the CEP, the singing of freedom songs, which were changed little from the

\footnotetext{
383 Clark, Echo in My Soul, 240.

384 Cotton, If Your Back's Not Bent, 126, 127.

385 Ibid.

386 See the following chapters for the relationship between Hamer and the civil rights leaders who raised her up.
} 
spirituals, produced great energy for resisting social injustice by providing religious justification for the work. ${ }^{387}$

Cotton taught nonviolent resistance in her classes. She developed seven steps for practicing nonviolent tactics. First, Cotton led the students to discuss and focus on the real problem to overcome, that is, "clearly identify the issue." 388 Second, Cotton asked students to "gather all pertinent information" and to bring enough details to the workshop so they could role-play relevant community issues. ${ }^{389}$ Third, Cotton led the students to take "the education step." 390 She encouraged them to identify people who needed to be educated. The CEP graduates would then distribute leaflets and radio announcements to publicize voting rights education for local people who wanted to practice their civil rights. The fourth step was developing "personal commitment." 391 Cotton believed that local organizations could expand their impact through strong people's commitment. She stressed that each social activist should be closely connected in order to develop social movement. Fifth, Cotton challenged students to focus on "negotiation." 392 For the most successful protests, Cotton believed that the students of the CEP should be intensely trained to clarify their goal and to give up minor issues in order to focus on the goal while also respecting their opponents as equal beings. The sixth step was a "direct action." 393 Cotton taught the students that a march should be considered a last resort for when other methods could not achieve the desired ends. The final step was "reconciliation." Cotton believed that reconciliation was the most critical goal for achieving effective movement through nonviolent tactics. Through her classes on nonviolent

387 Laura Visser-Maessen, Robert Parris Moses: A Life in Civil Rights and Leadership at the Grassroots (Chapel Hill: The University of North Carolina Press, 2016), 113.

388 Cotton, If Your Back's Not Bent, 181.

389 Ibid.

390 Ibid.

391 Ibid.

392 Ibid.

393 Ibid. 
methods, Cotton developed the tactics of the voting rights movement on a foundation of Christian teachings of love and peace. ${ }^{394}$ Cotton took the position as administrator of the CEP after Young left the position to work as the executive director of SCLC in 1964.

Annell Ponder worked for the field supervisor of the CEP, setting up local workshops and recruiting leaders. ${ }^{395}$ She had to oversee the CEP teachers and supervisors who were conducting the CEP workshops in ten counties. ${ }^{396}$ Through her visits, telephone calls, and memoranda, Ponder had close connections with local activists and SNCC field workers such as James Bevel and Bob Moses. When she was involved with citizenship schools in Mississippi, Ponder worked closely with Hamer and Bevel, who had recently been hired to work for the CEP. For these reasons, Ponder contributed to improving the relationship between SCLC and SNCC. There were two kinds of program assistants in the CEP. The parttime secretary of the CEP coordinated local workshops and communications, and SCLC field worker supervised and explained the statewide recruitment of SCLC. Ponder had to supervise these assistants. ${ }^{397}$ She was responsible for selecting teaching materials, for collecting information, and for keeping lists of the resources of the local CEP schools. ${ }^{398}$ Ponder had to compile these records because there were some local areas that were hesitant to share their materials with other areas due to their closefisted tendencies. She was required to resolve the problems with sharing information between the local CEP schools.

Ponder needed to promote social activities for community relations, such as lectures explaining the nonviolent struggle for freedom to local people. ${ }^{399}$ Through broadcasting, face-to-face interactions, and mailed letters, Ponder communicated with people at the grass

\footnotetext{
394 See the following pages for Cotton's Christian philosophy on developing the civil rights movement.

395 Young et al., “Annual Report,” 20.

396 Ibid.

397 Ibid.

398 Ibid.

399 Ibid.
} 
roots, law enforcement officers, and politicians. ${ }^{400}$ She was also responsible for working with other civil rights organizations. In particular, Ponder was sent to join the Council of Federated Organizations (COFO), which was sponsored by SCLC as one of its members. ${ }^{401}$ She attended the staff meetings of COFO and its community and state meetings. ${ }^{402}$ As part of COFO, she helped it coordinate a "community center program" and most of its programs for education and economic and political uplift. ${ }^{403}$ She also helped it analyze the social problems and the needs of local people in order to solve problems and improve social conditions. At the Dorchester Center, Ponder assisted with informal discussions and taught people how to plan and lead devotions. ${ }^{404}$ She was considered an SCLC worker with an SNCC mind frame. ${ }^{405}$ Through working with diverse civil rights organization, Ponder spent a lot of time with SNCC and COFO, expanding voting rights education into a Southern-wide movement.

In a letter to King, Ponder urged him to sponsor COFO because the organization would provide benefits to SCLC. ${ }^{406}$ She insisted that SCLC needed to support the overhead expenses of $\mathrm{COFO}$, including the costs of renting community centers and the headquarters office in Jackson, Mississippi, printing expenses, and the cost of room and board for its summer program. ${ }^{407}$ Ponder asked King to consider four major reasons for supporting COFO: "running of Negro candidates for Congressional offices, Freedom Schools for teenagers, voter registration (also 'freedom registration' similar to the 'freedom vote') and community centers. ${ }^{\circ 08}$ Moreover, Ponder beseeched King to support the legal suit against

\footnotetext{
400 Ibid.

401 Ibid. For more about COFO's activities for voting rights, see the following pages.

402 Ibid.

403 Ibid.

404 Ibid.

405 Student Nonviolent Coordinating Committee, "Digital SNCC Gateway," https://snccdigital.org/people/annell-ponder/.

406 Annell Ponder to Martin Luther King, Jr., January 28, 1964, KPKC, 136:1.

407 Ibid.

408 Ibid.
} 
the Winona police for their brutal treatment of her along with Fannie Lou Hamer, June Johnson, Euvester Simpson, Rosemary Freeman, and James West, who were working with SNCC and COFO. ${ }^{409}$ These activists were on their way to establishing citizenship schools in their communities after completing the Citizenship School program in 1963 when they stopped and ate lunch at a segregated restaurant (which had been declared unconstitutional, but local laws still approved it during that time). Police officers followed their bus and ordered them to be jailed at Winona, where they were severely beaten and whipped with studded leather straps. This brutal violence was witnessed to by Hamer before the Credentials Committee at the Democratic National Convention. Hamer's speech, called "Is This America?," gained nationwide attention, and President Lyndon Johnson was much more afraid of her testimony being known by many people than King's address at the same place. ${ }^{410}$ Ponder entreated King to support this legal case and testified to its importance for disclosing the brutality of segregation. Ponder's letter to King demonstrates her contributions to and deep engagement in the voting rights movement of SNCC and COFO. Her legal suit shows how the CEP worked closely with SNCC and COFO, which were the major organizations that joined SCLC in the Selma to Montgomery marches.

Bernice Robinson worked for the CEP as a kind of part-time or half-time field supervisor, because she continued to work for the HFS as a full-time director after Clark went to the CEP in $1961 .^{411}$ From 1964 to 1970 , she worked for the CEP as a full-time supervisor.

\footnotetext{
409 Ibid.

${ }^{410}$ Hamer's speech was broadcast and Johnson tried to block it. Bob Moses testifies to this event in American Experience PBS, "Fannie Lou Hamer's Powerful Testimony," an excerpt from Freedom Summer, June 24, 2014, YouTube Video, 3:40, https://www.youtube.com/watch?v=07PwNVCZCcY.

${ }^{411}$ In their autobiographies, Cotton and Young describe Robinson as a full-time field supervisor of the CEP; see Cotton, If Your Back's Not Bent, 111; and Young, An Easy Burden, 140. However, in her interview with Eugene Walker, Robinson clarifies that she had a full-time position at the HFS and not at the CEP by 1964. See "Interview with Bernice Robinson," by Eugene Walker, HFS Archives.
} 
Through the HFS's Citizenship School, Robinson trained most of the initial leaders of the CEP, such as Young, before the Citizenship School was transferred to the CEP. ${ }^{412}$ Robinson also trained leaders for the local areas through the joint workshops of CORE, COFO, and SNCC. Bob Moses of COFO and Charles Sherrod of SNCC were supervised by Robinson as they recruited for citizenship classes. ${ }^{413}$ Robinson, along with Esau Jenkins, supervised other activists of SNCC and COFO as they sought to establish voting rights schools in Mississippi, Georgia, Alabama, Louisiana, and other states. Robinson trained and consulted with many key activists, such as Medgar Evers, on "how to get people together, how to get voter turnout, how to get money to finance schooling — all that."414 Like Baker, Clark, and Ponder, Robinson tried to expand the Citizenship School program into other major civil rights organizations. Transcending the limits of organizational boundaries, Robinson impacted and bridged the voting rights movement between pre-existing organizations, such as SCLC and the NAACP, and new organizations of young people, such as SNCC and COFO.

Clark and Robinson were essential civil rights leaders for their contributions to creating new leadership within the civil rights movement through their grassroots tactics with the Citizenship School. In a letter to Cotton in 1961, Robinson stated that she had a job offer to work for the CEP as a full-time field supervisor, at Horton's recommendation. However, Robinson choose to stay with the HFS as a full-time director because she thought this would help conserve the Field Foundation grant, half of which was spent on salaries for CEP staff

\footnotetext{
412 "Interview with Bernice Robinson,” by Eugene Walker, HFS Archives.

413 Ibid.

${ }^{414}$ Ibid. For more about Robinson's work with Evers and other civil rights leaders, see the following pages.
} 
members. ${ }^{415}$ Instead of working full time for the CEP, Robinson promised Cotton that she would work for the CEP when it needed her services. ${ }^{416}$ Robinson asked Cotton to have the CEP pay her for her time and travel costs when she worked for the CEP. ${ }^{417}$ Robinson taught classes for refresher and five-day workshops and traveled to many places to supervise local citizenship schools. Thus, for the month of August in 1961, Robinson asked Cotton to pay her \$416.87, excluding taxes and social security. ${ }^{418}$ Robinson promised Cotton that she would continue working and stay on the CEP's permanent payroll if there were no workshops scheduled for the HFS. Robinson hoped that the CEP would gain the financial support to train more teachers in the future. ${ }^{419}$ Robinson traveled to a lot of cities to help teachers of the citizenship schools and to discuss with them how they could solve the problems and rectify the failures with their classes. Robinson set up the pattern of discussion-answers-practice as a teaching method of the Citizenship School to increase students' self-awareness of human rights. This teaching style was very attractive to the activists of SNCC and COFO, who wanted to develop grassroots leadership.

Robinson testified that there was one teacher who was forced to quit teaching local citizenship classes by her father's landlord and employer. As Hamer experienced, there were many sharecroppers who were threatened with termination from their jobs by their landlords when they tried to register to vote. Robinson met one female teacher at a district meeting in South Carolina and found out that the Citizenship School teacher faced the same threat as

415 Robinson to Cotton, August 1, 1961, KPKC, 153:1. There is a record of a budget for a salary for Robinson as a field supervisor of the CEP. According to the record, Robinson would receive \$7,000 per year from 1967 to 1969 and \$7,200 in the fiscal year 1969-1970. These amounts might be more than those of a half-time worker for the CEP, because Clark's annual salary as a full-time supervisor was $\$ 8,500$. See Dorothy Cotton, "Proposal for Citizenship Education Program to the Marshall Field Foundation," KPKC, 151:27.

${ }^{416}$ Robinson to Cotton, August 1, 1961, KPKC, 153:1.

417 Ibid.

418 Ibid.

419 Ibid. 
Hamer. The teacher said, "Teaching the people to read and write and to register and vote will be the salvation of their small community." ${ }^{420}$ Her father did not bend to his landlord's threat and registered in his daughter's class. Robinson shared that there was one student in her Citizenship School class who said it was the "first time I have felt like a human being," and the student was "so proud to get my registration certificate, I almost ran a stop light"; the student also asserted that "without her help, I would never have had the courage to register because I didn't have enough schooling and nobody took any interest in teaching me to read and write before now." ${ }^{21}$ These testimonies demonstrate the essential power of the Citizenship School, which challenged grassroots people to be bold in resisting their disenfranchised situation. Robinson supervised district meetings in other Southern states and encouraged local people to "get out the vote," despite their hopeless situation in the sharecroppers' economic systems. ${ }^{422}$

The Grassroots Leaders from the Citizenship Schools of the HFS and CEP

As a result of the students' sit-ins, the leadership structure of the civil rights movement had shifted to ordinary people who stood up for themselves against the segregation system. During the years of the sit-ins, the key people of the sit-ins and SNCC were deeply influenced by the HFS's Citizenship School because the key leaders, Ella Baker and James Lawson (who encouraged the sit-in students to establish SNCC), were also supporters of the Citizenship School. Lawson highly recommended that his nonviolent workshop students join the HFS's Citizenship School. Three of his students, John Lewis, James Bevel, and Diane Nash, who were the key leaders of SNCC, did so. They would later be crucial people in the leadership of the Selma to Montgomery marches. Their experience at the HFS greatly impacted the establishment of grassroots leadership for the civil rights

420 Bernice Robinson, "Report from the Field," 1964, KPKC, 155:30.

421 Ibid.

422 Ibid. 
movement. Bob Moses, who led the Freedom School of SNCC and COFO, was also deeply influenced by the Citizenship School and applied its tactics to the Freedom School, as Robinson had advised. Hamer also started her civil rights struggle with voter registration and dedicated her life to desegregating voting rights. These civil rights leaders opened a new era for the grassroots leadership of the civil rights movement through the voting rights movement, and they continued to lead sit-ins, the March on Washington, the Freedom Summer, and the Selma to Montgomery marches. All of them were highly motivated by the Citizenship School and worked closely with the CEP.

Moses said, "I think that one of the most powerful and beautiful things about the movement was that it enabled people like Mrs. Hamer to emerge."423 Hamer was one of the first graduates of the CEP's five-day workshops, and she actively implemented grassroots leadership. It was well-known that, after she heard the speeches of James Bevel, Bob Moses, and James Forman at SNCC's voting rights meeting in 1962, she tried to register to vote. ${ }^{424}$ As Moses implied, Hamer was a very different leader from other civil rights leaders, because, unlike her, there had been no other leaders who had lived and worked on a sharecropper plantation. ${ }^{425}$ Hamer powerfully witnessed to her experience of racial segregation and brutality. When she tried to register, Hamer was fired by her farm's owner and had to leave her home. In 1963, when Hamer and her co-workers of her voting rights workshop traveled to set up citizenship schools and went back to Mississippi, they were caught by police officers and severely beaten by jailers at Winona. SNCC people were astonished by the power of Hamer's testimonies and realized that Hamer was the person they had been looking for-a

423 Robert P. Moses and Charles E. Cobb, Jr., Radical Equations: Civil Rights from Mississippi to the Algebra Project (Boston: Beacon Press), 80.

${ }^{424}$ Lewis, Walking with the Wind: A Memoir of the Movement, 187.

425 American Experience PBS, "Fannie Lou Hamer's Powerful Testimony." 
grassroots person who was an eyewitness to the brutal segregation of the Deep South. ${ }^{426}$ SNCC people invited Hamer to join their organization as a field secretary.

Four major organizations were involved in making Hamer a grassroots leader of the civil rights movement. In 1962, Hamer heard the speeches of SNCC voting rights activists at her church, she tried to register for voting at the next day. ${ }^{427}$ After her first attempt to register failed, it became known by the local newspapers. Hamer was fired from her job as a timekeeper for a sharecropper plantation, and she had to stay at the home of her neighbor, Mary Tucker, who invited her to attend an SNCC meeting. ${ }^{428}$ Tucker's home was shot at by local racists, so Hamer had to find other places to stay. While she was residing at the home of her niece, Cascilla Hamer, who supported SNCC, Ella Baker asked Charles McLaurin to bring Hamer to SNCC's Nashville conference. ${ }^{429}$ After the conference, SNCC hired Hamer as a field worker. SCLC's CEP trained her how to organize the citizenship education in her community of Mississippi when Hamer visited the Dorchester Center. ${ }^{430}$ With the CEP's education for voting, Hamer could pass the literacy exam and register to vote at her second try. As a SNCC field worker, Hamer led the local people to register and taught them at the citizenship classes. When Hamer tried to help co-workers to set up local citizenship schools with Ponder of the CEP and other activists, they were jailed and beaten by Winona jailers. ${ }^{431}$ Bernice Robinson of the HFS was working with Moses teaching citizenship education in Mississippi when she heard that her co-workers had been beaten and wounded at the Winona jail. ${ }^{432}$ Robinson reported the Winona beatings to Horton, who passed the word on. Cotton,

${ }^{426}$ Kay Mills, This Little Light of Mine: The Life of Fannie Lou Hamer (Lexington: The University Press of Kentucky, 2007), 40.

427 Young, An Easy Burden, 151.

428 Chana Kai Lee, For Freedom's Sake: The Life of Fannie Lou Hamer (Urbana: The University of Illinois Press, 1999), 34.

429 Ross, Witnessing \& Testifying, 103.

430 Young, An Easy Burden, 151.

431 Lee, For Freedom's Sake, 45.

432 Branch, Parting the Waters, 825. 
Young, and Bevel were then able to bail Hamer and the others out of jail and get them to a doctor. ${ }^{433}$ After Hamer's recovery, SCLC sent $\$ 100$ to Bevel to rent a car and a house for Hamer. ${ }^{434}$ This civil rights struggle of Hamer greatly impacted the development of a new phase of grassroots leadership during the civil rights movement era. Supporting Hamer's emergence as a grassroots leader, SCLC, SNCC, COFO, and the HFS cooperated in helping her to lead the voting rights movement.

Young realized the importance of emergency assistance in Hamer's case. He asked the Field Foundation to grant an addition $\$ 15,000$ a year, so the CEP could pay field teachers \$30 per month for their work, because they had frequently engaged in the emergent civil rights struggle without any stipends. ${ }^{435}$ While she was teaching citizenship education classes, Hamer organized with Moses the voting rights campaigns that propelled voter registration statewide, the Freedom Vote in 1963, and the Freedom Summer in 1964. Hamer also helped organize the Mississippi Freedom Democratic Party (MFDP) in 1964 when the regular Democratic Party rejected African American candidates. ${ }^{436}$ The MFDP was set up to provide African Americans with full participation in the political process, and it elected Hamer as its vice chair. Even though the MFDP failed to gain seats in the Democratic Party, John Lewis remembered that the Mississippi projects led the African American Mississippians to "vote in meaningful numbers." ${ }^{437}$ Through the Freedom Vote, Hamer contributed to leading about 90,000 African American Mississippians to vote. ${ }^{438}$ The MFDP influenced the passing of the Voting Rights Act in 1965 through its constantly challenging the Democratic National

\footnotetext{
433 Ibid.; and Young, An Easy Burden, 253-258. For more about the CEP's help with and female leadership in relation to the Winona jail incident, see the following chapters.

434 Young, An Easy Burden, 151.

435 Ibid., 152.

436 Ross, Witnessing \& Testifying, 108.

437 Lewis, Walking with the Wind, 244.

438 Ibid.
} 
Committee to request delegations of desegregated voters. ${ }^{439}$ Hamer was elected as a delegate of the MFDP in 1968 and 1972 at the Democratic National Conventions. ${ }^{440}$

John Lewis was moved by King's speech on the Montgomery Bus Boycott that was broadcast on the radio and by Emmett Till's murder, and he consequently dedicated himself to the civil rights movement. When he attended the American Baptist Theological Seminary in Nashville, Tennessee, Lewis joined James Lawson's workshop sponsored by the Fellowship of Reconciliation (FOR). In Lawson's workshop, Lewis learned nonviolent tactics and philosophy and how to use "soul force" to pursue "love in action." ${ }^{441}$ Lawson recommended that his students join the HFS's Citizenship School. Lewis went to the HFS with his friends, including James Bevel, who was his seminary colleague, and he wanted to have the chance to meet any women there. ${ }^{442}$ During the HFS workshop, Lewis and Bevel learned from Clark and Horton about grassroots leadership and the need for voting rights education for local people. ${ }^{443}$ After he completed the workshop at the HFS, Lewis attended the conference in Raleigh, North Carolina, that resulted in the founding of SNCC. Baker, Clark, Horton, and Lawson baptized Lewis in their philosophy of grassroots leadership, which did not allow any organization or person to lead or control the grass roots' spirit. ${ }^{444}$ His colleagues in Lawson's workshops were Bernard LaFayette, James Bevel, Diane Nash, and Stokely Carmichael, who led the civil rights actions of SNCC, such as the sit-ins, voting rights education, and the Selma to Montgomery marches.

As they learned about the grassroots movement from the workshops of Lawson and the HFS, Lewis, Nash, LaFayette, and other pre-SNCC activists began to engage in the sit-in

\footnotetext{
439 Ross, Witnessing \& Testifying, 109.

440 Ibid.

441 Lewis, Walking with the Wind, 76, 78.

442 Ibid., 80, 81.

443 Ibid., 81, 82.

444 Ibid., 82.
} 
movement in $1960{ }^{445}$ Lewis's colleagues spontaneously participated in sit-ins in Raleigh after they heard that there were sit-ins at the Woolworth's store in Greensboro. They were also able to share information about the sit-ins with Douglas Moore, who led the sit-ins in Durham, North Carolina, because Lawson was a friend of Moore's. ${ }^{446}$ During their sit-ins, they used the same types of tactics that had been shared in the HFS's and Lawson's workshops. Lewis made the following list of dos and don'ts for sit-ins:

DO NOT: $1 . \quad$ Strike back nor curse if abused.

2. Laugh out.

3. Hold conversations with floor walker.

4. Leave your seat until your leader has given you permission to do so.

5. Block entrances to store outside nor the aisles inside.

DO: $\quad$ 1. Show yourself friendly and courteous at all times.

2. Sit straight; always face the counter.

3. Report all serious incidents to your leader.

4. Refer information seekers to your leader in a polite manner. Remember the teachings of Jesus Christ, Mahatma Gandhi and Martin Luther King. Love and nonviolence is the way. ${ }^{447}$

Lewis's sit-ins colleagues also sang freedom songs such as "We Shall Overcome" when they were warned and jailed by police officers, as they had learned to do from the HFS's workshop. ${ }^{448}$ When Lewis and pre-members of SNCC attended the Raleigh conference, even though King and SCLC leaders urged them to join SCLC, they made a decision to establish a new civil rights organization for young people based on the teachings of Baker, Clark, and Lawson, who focused on grassroots leadership and self-awareness tactics. ${ }^{449}$ As the third chairman of SNCC who was pro-King with his nonviolent tactic and achievement in the civil rights movement, Lewis took a major role in leading the Freedom Rides, the March on Washington, the Freedom Summer, the voting rights drives with the MFDP, and the Selma to

$$
\begin{array}{ll}
445 & \text { Ibid., } 87 . \\
446 & \text { Ibid., } 92 . \\
447 & \text { Ibid., } 98 . \\
448 & \text { Ibid., } 100 . \\
449 & \text { Ibid., } 108 .
\end{array}
$$


Montgomery marches. Along with his experience with the HFS's workshop, Lewis practiced his tactics for the grassroots movement in these major civil rights activities.

James Bevel was known by the NBC paper which profiled him as one of the leaders of "the Nashville Sit-in Story." 450 As Lewis described him, Bevel was an enthusiastic and soulful preacher and the spokesman for SNCC and SCLC. Young cited Bevel's emphases for the civil rights movement as "picking up one's soul, and walking with one's soul." ${ }^{451}$ In the Mississippi Delta, Bevel began voting rights efforts with Sam Block and Willie Peacock of SNCC in $1960 .{ }^{452}$ During their meetings in Mississippi, Hamer was inspired by Bevel's preaching on Luke 12:54-57, “. . . . Hypocrites! You know how to interpret the appearance of the earth and the sky. How is it that you don't know how to interpret this present time? ...." Bevel combined with these verses for discerning the signs of "this present time" to do right for social justice. ${ }^{453}$ King tried to persuade many SNCC members to join SCLC as paid workers. ${ }^{454}$ This was a tempting offer because many SNCC members were being financially burdened by bails, penalties, and living expenses. While Lewis rejected King's offer, Bevel agreed to be a field secretary in Mississippi for SCLC when he faced emerging disagreements among SNCC members. ${ }^{455}$ However, Bevel continued working closely with SNCC on the voting rights drives in Mississippi because he was one of its early members, and his wife, Diane Nash, was the leader of SNCC.

Bevel worked with Young to develop a Christian philosophy for the CEP's voting rights drives. Having ministerial minds, Bevel and Young, who were employed by the CEP, together dedicated themselves to contacting and caring for the local community leaders in

\footnotetext{
450 Young, An Easy Burden, 126.

451 Ibid., 150.

452 Ibid.

453 Ross, Witnessing \& Testifying, 99.

${ }^{454}$ Lewis, Walking with the Wind, 183.

455 Ibid.
} 
Birmingham. Unlike Walker, who focused on the relationship between King and the media, Young and Bevel focused on relationships with local people as one of the CEP's tactics. ${ }^{456}$ Young testified that focusing on the local community was the major difference in SCLC's Birmingham Campaign from its Albany Movement, which provided lessons for Birmingham. ${ }^{457}$ This new phase of SCLC was initiated by the work of Bevel and Young, who, as fellow ministerial leaders, could suggest to the clerical leaders of SCLC that they change their tactics. Bevel's approach of combining citizenship education with mass movement was successful in the Freedom Rides, the Birmingham Campaign, the March on Washington, the Freedom Summer, and the Selma to Montgomery marches. Like Ponder, Bevel was an essential leader of the grassroots movement because he was able to unite the work of the major civil rights organizations: SCLC, SNCC, COFO, and the MFDP.

Diane Nash initiated her involvement with the civil rights movement during the Nashville sit-ins. She attended Fisk University and joined Lawson's workshops. According to Clark, Nash attended the HFS's college workshop of the Citizenship School along with Bevel and Lewis. ${ }^{458}$ Through the workshops of the HFS and Lawson, Nash began working for the citizenship education program of SNCC and the Freedom Summer while she led several direct actions, such as sit-ins, Freedom Rides, the Birmingham Campaign, and the Selma to Montgomery marches. Like Lewis and other founding members of SNCC, Nash was impacted by Baker's grassroots movement. With her husband, James Bevel, Nash worked on voting rights education in the Mississippi Delta. Bevel was a field secretary for the CEP, and Nash could join the work of SCLC as one of the leaders of SNCC. Nash testifies, "To begin

\footnotetext{
456 Young, An Easy Burden, 189.

457 Ibid.

458 "Interview with Septima Clark," by Eugene Walker, HFS Archives.
} 
with, my husband and I had planned to spend the rest of our lives in Mississippi working for the liberation of black people."459

In 1962, when she was twenty-three years old and six months pregnant, Nash was sentenced to be jailed due to her Freedom Rides. Even though she was pregnant, Nash insisted on staying in jail without bail: "jail-no-bail" because she wanted to resist without making a compromise with the evil social system and believed that her baby would be born better in jail than in segregated Mississippi. ${ }^{460}$ Nash was sentenced to serve two and half years in jail; however, Judge Russell Moore released her after she had spent ten days in jail, but she refused to leave. Nash was ready to give birth in jail and even be killed; she said, "If they had killed me, I was ready." 461 With her husband, Nash participated in SCLC's Birmingham Campaign, voting rights workshops, and direct actions to vote. She insisted that nobody led her to engage in civil rights actions, rather, the Spirit led her to engage in these actions. ${ }^{462}$ As she was initially inspired by the HFS's and Lawson's workshops to join the civil rights movement, Nash founded the educational focus as one of the traditions of SNCC: "SNCC and I were in agreement that it was crucial for people to be educated in how to carry on liberation struggles and make decisions themselves rather than simply follow what 'leaders' told them to do." 463 Bevel and Nash attended senior staff meetings of SCLC along with King, Abernathy, Cotton, and Young during the mid-1960s. ${ }^{464}$ By teaching the grassroots people in Mississippi, Nash and Bevel played a crucial role in organizing the Selma to Montgomery marches. As the essential organizers of the Selma to Montgomery

459 Diane Nash, "They Are the Ones Who Got Scared," in Faith S. Holsaert et al., eds., Hands on the Freedom Plow: Personal Accounts by Women in SNCC (Urbana: University of Illinois Press, 2010), 78-82.

460 Ibid., 82.

461 Ibid., 78.

462 Ibid.

463 Ibid., 76.

464 Young, An Easy Burden, 382. 
marches, Nash and Bevel could attribute their organizing skills to what they learned in the workshops of the HFS's Citizenship School and Lawson's workshops.

Hosea Williams worked for the local NAACP and met Young after he was fired from the Savannah Department of Agriculture for his involvement in the civil rights movement. ${ }^{465}$ Williams was attracted to the movement by the Citizenship School at the Dorchester Center and worked for the CEP as a district supervisor in Savannah, Georgia. In 1961, Williams also worked as the president of the Southeast Georgia Crusade for Voters (SGCV), which was affiliated with the CEP. ${ }^{466}$ He organized the "get out the vote" campaign with the Southern Regional Council (SRC) in the state of Georgia. ${ }^{467}$ His voting rights education programs and direct actions in Georgia were very successful. According to a report by Williams, he organized SCLC's Summer Community Organization and Political Education project (SCOPE) and was able to get over one thousand summer workers in six states and ninety-six counties to participate in $1965 .^{468}$ The summer workers for SCOPE were able to contact over 800,000 African Americans in the South. At the time of the report, among those contacted, 300,000 had taken education classes; 170,000 had tried to establish citizenship classes in their communities; 46,000 were in the process of being registered; and 16,000 had been registered to vote. ${ }^{469}$ Williams also attended senior staff meetings of SCLC with Bevel, and they would insist on strong direct action for their political needs without counting the costs of such action. ${ }^{470}$ However, Williams's broad contacts and experience with voting rights efforts with

\footnotetext{
465 Ibid., 259.

466 Hosea Williams, "History and Philosophy of the Southeastern Georgia Crusade for Voters," KPKC, 139:22.

467 Ibid.

468 Hosea Williams, "Press Statement 222," KPKC, 121:1.

469 Ibid.

470 Young, An Easy Burden, 384.
} 
local people were crucial contributions to the success of SCLC's St. Augustine campaign. ${ }^{471}$ This campaign played a key role in the passing of the Civil Rights Act of 1964.

Williams was an exemplary leader who united the tactic of educating grassroots people with direct action. These hybrid tactics were generally accepted among SCLC, SNCC, COFO, and the MFDP, which established a new phase of grassroots leadership and successfully accomplished the passing of desegregating laws. Williams served in the army in the Second World War. Saved from the German army’s bombs, Williams was disabled and could not walk without crutches. ${ }^{472}$ Williams believed that God had saved him from the war and sent him to fight against segregation in American society. ${ }^{473}$ In 1963, when he was thirty-three years old, Williams was jailed for violating the good behavior warrant sign of a white person during a direct action. ${ }^{474}$ Williams was finally released by paying peace bonds of about \$30,000. African American businessman Russell Lavender signed over his real estate, which included over 20 housing units, in order to free Williams. ${ }^{475}$ When Williams was jailed in Savannah, there were 800 people who were jailed with him. He raised $\$ 250,000$ to pay their bonds. When someone asked him, "Would you go to jail again?" Williams responded, "I would if I have to." 476 King praised Williams's achievements in voting rights education, calling his work "one of the most significant voter registration drives ever held in the south." ${ }^{477}$ Williams was a phenomenal grassroots leader of SCLC, as evidenced by his success in expanding the citizenship schools and his direct actions for voting.

\footnotetext{
471 Ibid., 290.

472 Ibid., 259.

473 Ibid.

474 SCLC, "Hosea Williams in Savannah Jail 34 Days Now Seeks \$250,000,” KPKC, 139:23.

475 Ibid.

476 Ibid.

477 Junius Griffin, "Southern Christian Leadership Conference News," February 5, 1966, KPKC, 122:1.
} 
Bob Moses was mesmerized by the pictures of the student sit-ins and went to Mississippi in 1960. He was inspired by the speeches of Ella Baker, who helped him recognize the power and value of grassroots leadership for the civil rights movement. ${ }^{478}$ Moses visited SCLC headquarters and worked there as a summer volunteer in $1960 .{ }^{479} \mathrm{He}$ met Baker, King, and Walker while they were in the process of adopting the HFS's Citizenship School. Moses came to question SCLC leaders' dependence on one leader and agreed with Baker's idea of using grassroots leadership to develop the civil rights movement. ${ }^{480}$ Moses participated in SNCC meeting at the HFS. ${ }^{481}$ This meeting was the initial meeting for discussing and determining the tactics of SNCC. The student leaders decided to drop out of their undergraduate classes and work for SNCC full time as field secretaries. ${ }^{482}$ Learning from Baker's and the HFS's tactics, SNCC leaders established the two directions of their civil rights movement according to Baker's recommendation: one was to develop the Nashville student civil rights actions, which would be led by Diane Nash, and the other direction was voter registration drives led by Charles Jones. ${ }^{483}$

Moses's voting rights education program in McComb, Mississippi was the first voting rights education program of SNCC. Even though the voting rights schools were less obtrusive activities than those of the sit-ins and the Freedom Rides, Moses and his co-workers had to face death threats from local racists. Moses's co-worker Herbert Lee was shot and killed by a white racist, who was eventually acquitted. ${ }^{484}$ Moses was also shot at, and Jimmy Travis, who was beside Moses, was shot and hospitalized. There were several voting rights activists who were shot at in Mississippi. The Taconic Foundation and the Field Foundation granted

\footnotetext{
478 Moses and Cobb, Radical Equations, 4.

479 Ibid., 31.

480 Ibid., 28.

481 Ibid., 44.

482 Ibid.

483 Ibid.; and Zinn, SNCC: The New Abolitionist, 59.

${ }^{484}$ Moses and Cobb, Radical Equations, 50.
} 
funds to SNCC's voting rights education through the Voter Education Project (VEP) of the Southern Regional Council. Moses organized the Council of Federated Organizations (COFO), which was a joint body of SNCC, SCLC, CORE, the NAACP, and the Urban League to support and develop the voting rights movements of these diverse institutions. ${ }^{485}$ Robinson advised Moses on how to establish voting rights schools and how to make teaching materials and schedules. ${ }^{486}$ Moses worked with Hamer and Ponder on voting rights education in Mississippi and led the successful voter registration drives that founded the Selma to Montgomery marches. He was Harlem-bred, had a master's degree from Harvard University, and dedicated his life to educating grassroots people in the South. Moses implemented grassroots leadership in the Mississippi Delta as Baker and the HFS had inspired him to do.

There were many civil rights activists who were trained by the Citizenship School of the HFS and the CEP. From 1960 onward, Medgar Evers, who was advised by Robinson, was the field secretary of the NAACP and began the first voting rights education program of that organization in Mississippi. ${ }^{487}$ He worked for voting rights education in dangerous areas of Mississippi with SNCC activists, and Evers's assassination in 1963 awakened people to realize the value of the civil rights movement nationwide. James Forman of SNCC introduced Moses to Robinson and asked her to help them establish voting rights workshops in Mississippi. ${ }^{488}$ Major Johns worked for SNCC; however, he discovered that sit-ins were costly in terms of paying bails and fees, and then the organization had less resources for training field activists. Johns asked that Young be hired by the CEP, and Johns began

\footnotetext{
485 Zinn, SNCC, 79, 80.

486 "Interview with Bernice Robinson," by Eugene Walker, HFS Archives.

487 Medgar Evers to Amzie Moore, April 19, 1960, Wisconsin Historical Society, Freedom Summer Collection, 1:4, http://content.wisconsinhistory.org/cdm/ref/collection/p15932coll2/id/21902.

${ }^{488}$ Highlander Folk School, "Three-Year Report: Highlander Research and Education Center, Inc.," August 28, 1961-December 31, 1964, KPKC, 154:9.
} 
working for the field secretary in $1962 .{ }^{489}$ He was successful in Louisiana as a state supervisor of the CEP and closely worked with the MFDP.

The voting rights movement of the young grassroots leaders provides distinct evidence of the change in the leadership paradigm of the civil rights movement due to the impact of the Citizenship School. Moreover, the powerful tactics of the Citizenship School unified the diverse civil rights organizations, which magnified the voting rights movement to a Southern-wide level. The work of the grassroots leaders of the CEP and SNCC confute the claims of the media that SNCC and SCLC primarily argued with each other over differing tactics. Rather, the two organizations worked closely together toward the same goal of desegregating voter registration. The grassroots leadership tactics of the Citizenship School integrated the voting rights efforts of the civil rights organizations and led them to engage in successful mass movements, such as the Birmingham Campaign, the Freedom Summer, and the Selma to Montgomery marches.

\section{Christianity and the CEP's Voting Rights Movement}

Young, Bevel, and Williams were key leaders of the CEP as pastors. They tried to set up a Christian philosophy for defining the voting rights movement. As a laywoman, Clark initially insisted that churches and ministers had a responsibility to join the voting rights movement. These leaders of the Citizenship School motivated American Christians to find the religious value of voting rights, practice their own rights, and respect others' rights. Clark perceived that the voting rights movement of the Citizenship School was mostly supported by Christians, even though the supporters of the HFS formally opened it to non-sectarians who were people of "all faiths, creeds and religions." ${ }^{490}$ Clark thought that African American pastors in the South were the main constructors of Southern Christianity's leadership;

489 The National Sharecroppers Fund, Inc., to Andrew Young, August or September 1962, KPKC, 134:4. ${ }^{490}$ Clark, Echo in My Soul, 214. 
however, their leadership was supported by "numerous leading laymen." ${ }^{491}$ Clark explained that "the Negro church" had been the only forum for African Americans when they needed to express their "views, desires and hopes." ${ }^{492}$ She also believed that black churches had been the "principal organization" which led African Americans to have "social intercourse" with their neighbors. ${ }^{493}$ Thus, Clark thought that the pastors of black churches had been leading their people to protest and to seek a "better life for the Negro."494 Clark saw that black churches could provide broader opportunities to expand the voting rights movement in the South than the HFS. ${ }^{495}$ This was the reason why Clark decided to work with the pastoral leadership and church affiliations of SCLC.

Clark supported SCLC's Christian practice of nonviolent resistance. She believed that SCLC promoted the Christian value of every right for which they fought because they wanted to glean "truth force" from their movement as Gandhi had, in order to highlight the true value of resistance through nonviolent practice. ${ }^{496}$ Through the nonviolent resistance of the oppressed, Clark thought that the victory of the civil rights movement could be achieved-by converting oppressors from enemies into friends, not by humiliating them for their evil practices. Clark insisted that nonviolent resistance was "the most powerful weapon" for people who were struggling for and seeking human dignity and freedom. ${ }^{497}$ Clark also agreed with the philosophy of "redemptive suffering" preached by King and Lawson. She believed that suffering should be accepted by the oppressed while they fought against the oppressors' evil through nonviolent ways. Clark thought that suffering without retaliation could demonstrate the purpose of the civil rights movement to show that social evil could be

\footnotetext{
491 Ibid.

492 Ibid.

493 Ibid.

494 Ibid.

495 Ibid.

496 Ibid., 215.

497 Ibid.
} 
conquered through love. ${ }^{498}$ Clark's support for the nonviolent movement of SCLC meant that it could be taught in the CEP's workshops. These workshops would have more of a practical impact than King's speeches because the workshops could train people at the grass roots in nonviolent tactics in more accessible ways.

Young, Bevel, and Williams developed a Christian philosophy for the practices of the voting rights movement. Young wrote a manual to be included in the CEP's workbooks called "The Bible and the Ballot: A Manual of the Minister's Role in Political Education." 499 This manual was written in 1968 after King was assassinated. In this text, Young, as the executive vice president of SCLC, summarizes the Christian purposes and goals of the voting rights movement up until then. He defines the pastor as a witness of Jesus Christ in this world, and asserts that God called pastors to witness for the purpose of "the redemption of the world," as Jesus had. ${ }^{500}$ Thus, pastors who were the witnesses of Jesus would be persecuted for practicing the will of God, just as King had been killed for his work and just as civil rights activists in the South were being shot at and black churches were being bombed. ${ }^{501}$ Young believed that "God works through the political order to make His kingdom come on earth." 502 Thus, in his manual he insists that God's churches and people have a responsibility to express their voices through voting for the general good and for the best directions for their social communities. Young highlights that the true children of God should vote as part of their "Christian responsibility for the political life of man."

\footnotetext{
498 Ibid.

499 Andrew Young, "The Bible and the Ballot: A Manual of the Minister's Role in Political Education," KPKC, 123:34.

500 Ibid., (1).

501 Ibid.

502 Ibid.

503 Ibid.
} 
To provide a biblical premise for his philosophy, Young insists in his manual that God's concern is for "all of his Creation" because "God so loved the world (John 3:16)." Thus, God sent his children, who practiced their political responsibility for implementing the will of God, for the sake of the world because God loved the world and wanted all people in the world to work as his children to bring the world under his rule. ${ }^{505}$ Based on the Bible verse, "According to His purpose which He set forth in Christ as a plan for the fullness of time, to unite all things in him, things in heaven and things on earth" (Ephesians 1:10), Young argues that God planned for all things to be united and to live together in harmony. ${ }^{506}$ He consistently interprets "the dividing wall of hostility" that Christ broke down (according to Ephesians 2:14) as "the walls of a racist society," which should be destroyed through voting. ${ }^{507}$ Young believed that God's kingdom consists of power (1 Corinthians 4:20), and the power of good should rule over evil in this kingdom. Thus, in his manual, Young insists that the ballot can give people an opportunity to advance the kingdom in this world. ${ }^{508}$ Moreover, Young thought that the kingdom of God already exists among people and that it progressively matures. This thinking was based on Jesus's saying, "it [the kingdom of God] is in the midst you" (Luke 17:21), and on his parable in Matthew 13 in which the kingdom of God "is like a mustard seed" that grows into the largest tree (Matthew 13:31-32).

Consequently, Young asserts in his manual that the kingdom of God is "in our midst" in such forms as the civil rights movements in Montgomery, Birmingham, Albany, and Selma, where

\footnotetext{
504 Ibid., (2).

505 In the manual, Young uses the plural form "his sons," because he wants to highlight that God's call for Christians is the same as God's call to Jesus. See Young, "The Bible and the Ballot."

506 Ibid.

507 Ibid.

508 Ibid.
} 
God's people marched for freedom. ${ }^{509}$ In other words, he held that the kingdom of God is visible in votes for the reformation of society, like a growing tree.

In the manual, Young quotes Luke 4:18-19, verses which were often used in the Citizenship School: "The Spirit of the Lord is upon me, because He has anointed me to preach good news to the poor. He has sent me to proclaim release to the captives and recovery of sight to the blind, to set at liberty those who are oppressed, to proclaim the acceptable year of the Lord." Young interprets this message to be the first sermon and ministry of Jesus, and we have to accept this ministry as Jesus' disciples. Young points out that "the good news to the poor" means today, "all men are equal and God loves all." 510 Thus, Young believed the voting rights movement could release "the captives of this society" and was a freedom movement according to God's will. ${ }^{511}$ In the manual, Young also cites Exodus 4:2-5, in which Moses performs miracles with his rod, and he says that the rod symbolized "the talent and responsibility" of God's people. ${ }^{512}$ Young claims that the talent and responsibility of God's people in his time are to gain voting rights for people; if they used these rights for good, the oppressed could become free. Young also interprets the Book of Jonah as a warning to the people of God not to run away from their responsibility to work for the kingdom of God. According to Young's manual, "political education gives us a new opportunity to assume our responsibility and redeem the soul of America through the ballot." 513

In the manual, Young identifies the African American voters as the prophets to the nations based on Jeremiah 1:4-10, "See this day I have set you (Jeremiah) over nations and over kingdoms, to pluck up and to break down, to destroy and to overthrow, to build and to

\footnotetext{
509 Ibid., (4).

510 Ibid., (3).

511 Ibid.

512 Ibid., (2).

513 Ibid., (3).
} 
plant."514 According to the manual, Young's premise is that the United States could be the "moral leader to the world" if African American voters can end the racial prejudice in this country. Thus, African American voters could give the prophetical message to the world." In the manual, Young insists that Christian voters have to help the poor people in the world through challenging government and making politicians establish laws for the poor as Jesus said, "Truly, I say to you, as you did it not to one of the least of these my brethren, you did it not to me" (Matthew 25:45)." "516 Feeding the poor people is the responsibility of government which is needed to establish the programs for the poor, and Christians have to vote for the politicians who understand this responsibility according to Young's manual. Based on the biblical story in Deuteronomy 1:6-40), Young thought that the people of the black churches were at "the threshold of the promised land" (the kingdom of God) and they had to be courageous to enter the land with God's covenant as the younger generation of Israelite and Joshua did..$^{517}$

In his manual, Young concludes that black church ministers are community leaders who are required to educate all their church members to register and to understand Christians' political responsibilities. ${ }^{518}$ Thus, Young suggests that ministers should work for the voting rights of their church members and community people according to the following guidelines:

1. Meet with community leaders.

2. Develop and organize voter registration.

3. Help choose committee chairmen carefully (consider the person's commitment, time, experience, etc.).

4. Get local leadership to set up an office.

5. Get tapes of Dr. King and Dr. Abernathy on voting.

6. Make volunteer staff assignments.

\footnotetext{
514 Ibid.

515 Ibid.

516 Ibid., (4).

517 Ibid.

518 Black churches used to recommend that every church member register to vote as a practice of their tradition. Even today there are many black churches that have tables for signing voting registration forms after their Sunday services. See page 27 for the recommendations of King's Dexter Avenue Baptist Church. 
7. Set up mass meetings at least every two weeks in all parts of the city; get speakers committed.

8. Set up material distribution outlets; develop a list of local resources.

9. Hold daily staff meetings; prepare for every meeting.

10. Push local issues.

11. Saturate your community with work solicitation forms.

12. Talk with newspaper editors; talk on radio; keep public-address systems in the streets; pass out handbills; post posters; constantly send out news releases; make church announcements; distribute buttons; get other leaders to speak on the radio and at meetings. ${ }^{519}$

Through his explanations of the Christian responsibility to vote, Young develops Christian thinking that justifies the voting rights movement to Christians nationwide. Thus, Young tried to develop both Christian theory and practical tactics for the voting rights movement. As King had, Young appealed to American Christians by proclaiming the catchphrase "Redeem the soul of America." The premise of the catchphrase was that American Christians had to reform back to their original faith, meaning their founding of a so-called Christian nation without racial hatred; they were not being asked to revolutionize the whole system of their Christian faith. ${ }^{520}$

Young had been attending the meetings of the World Council of Churches (WCC) in Geneva as a representative of the Youth Department of the National Council of Churches and as an organizer of the Programme to Combat Racism (PCR) of the WCC. ${ }^{521}$ Through his participation in the WCC meetings, Young tried to spread the Christian efforts of SCLC and the CEP's Citizenship School into the world. In order to communicate the effectiveness of the Citizenship School for the civil rights movement in American society, Young had to share the Christian underpinnings and implications of the Citizenship School and SCLC's civil rights movement.

519 Young, "The Bible and the Ballot," 5.

520 Ibid.

521 Young, An Easy Burden, 117. 
At the WCC meetings, Young presented an article titled "God's Action in History: A case study — the Freedom Movement." 522 In this article, Young examines how the church becomes involved in a "racial revolution," how God works in this revolution, and how the church guides the revolution on "the way from segregation to integration." 523 He interprets "Freedom Movement" as "a general term" that indicates the struggle of minority people for "civil rights, housing, employment, education and access to public facilities." 524 According to this article, the nature of the revolutionary movement was that African Americans found themselves through implanting their faith into the struggle. Young points out the tension between "the worldly form of Christian community in the movement and the Sunday congregation in their separate residential world." ${ }^{, 525}$ Thus, he emphasizes that the two forms of the church should be brought into "truer unity," and the effects of the church's sacraments and ministries could emerge in the world as community actions. ${ }^{526}$ For example, Young thought that the gifts of the charismatic leaders in the ministry could also be revealed "in the midst of the Movement." ${ }^{, 27}$ He states that ministry is "given with the existence of the laos, the people of God." 528 As Young highlights in the article, the ministry consists of "the varieties of gifts (charisma) that differ according to the grace given to the Gifts of the Spirit," so the leadership of the church is composed of people's unique gifts, which can be drawn upon to lead the Freedom Movement. ${ }^{529}$ Young also argues in the article that "the Freedom

522 Young, "God's Action in History: A Case Study_-The Freedom Movement," World Council of Churches 1964, KPKC, 135:21.

523 Ibid.

524 Ibid.

525 Ibid.

526 Ibid.

527 Ibid. According to Young, ministers of the church are not the only charismatic leaders; laypeople like Clark and Hamer, whose gifts have been given to them by the Spirit, also are. ${ }^{528}$ Laos is the English transliteration of the Greek word meaning "of the people." Young, "God's Action in History."

529 Ibid. 
Movement has demonstrated the close relationship between service and suffering." 530 Young thought that the charismatic leadership was based on the services of the church and could express the needs and cries of the people with "emotional impact" through their social actions, such as the mass movements. ${ }^{531}$ Finally, Young insists that the activists of the Freedom Movement should accept "the voluntary suffering" of their decision, meaning that they were willing to receive any legal penalty and suffer any violence toward innocent people in order to work against social injustice. ${ }^{532}$

In "One Man, One Vote," Young and Bevel insist that the United States fought for South Koreans' rights and this included their voting rights. ${ }^{53}$ They point out that Medgar Evers fought for Koreans' voting rights in the Korean War yet was killed for fighting for the voting rights of his neighbors in his hometown of Jackson, Mississippi. ${ }^{534}$ In the article, Young and Bevel point out that it is a dilemma of American society that the country fought for the voting rights of another country's people but not for African American citizens in its own country. ${ }^{535}$ They insist that the vote is "the means of Christian witness in a democratic society." ${ } 536$ Appealing to American people of the Christian tradition, Young and Bevel say that if Americans pray for "Thy kingdom [to] come," they have to create justice by desegregating voting rights and allowing African Americans to register to vote. ${ }^{537}$ Young and Bevel believed that "all God's children will be free" through desegregated voting rights for African Americans. ${ }^{538}$

\footnotetext{
530 Ibid.

531 Ibid.

532 Ibid.

533 Andrew Young and James Bevel, “One Man, One Vote,” 1961, KPKC, 135:23.

534 Ibid.

535 Ibid.

536 Ibid.

537 Ibid.

538 Ibid.
} 
Young and Bevel also wrote "Church and Citizenship—Negroes" to interpret the voting rights movement of the CEP from a Christian perspective. ${ }^{539}$ In this article, they hold that the Holy Spirit works in the CEP's curriculum as its context. They insist that citizenship education should not merely be understood as a movement for African Americans" "cultural level[ing] up," but should be considered a movement for "a God-given right," which is the definition of democracy. ${ }^{540}$ Based on the gospel message, Young and Bevel assert that we are "called into fellowship with God" as heirs and partners of God with Christ because Christ died for us. ${ }^{541}$ Thus, they insist that Christ broke down "the dividing wall of hostility between man and man and man and God" and that African Americans can overcome their images of self-hatred resulting from the sinful brainwashing of the oppressors. ${ }^{542}$

In "Church and Citizenship," Young and Bevel also describe the activists of the Freedom Rides and sit-ins as people who were spreading the "gospel of equality and sonship [as the Christ's partners] among some of the young people in Jackson, Mississippi." 543 Young and Bevel develop the concept of the Incarnation to explain the unique value of the Citizenship School. They say that if we believe we are the children of God, "the Incarnation is a reality in our life." ${ }^{544}$ Young and Bevel understand that the Incarnation as a reality of our life is "God-awareness" in our struggle, that "life involves the necessity of suffering for what is right." ${ }^{n 55}$ Thus, they insist that the Incarnation and voluntary suffering are the sources of the citizenship training, and the participants in the training "really learn of the power of love as a moral force capable of overcoming the evils of the world." 546 Young and Bevel assert

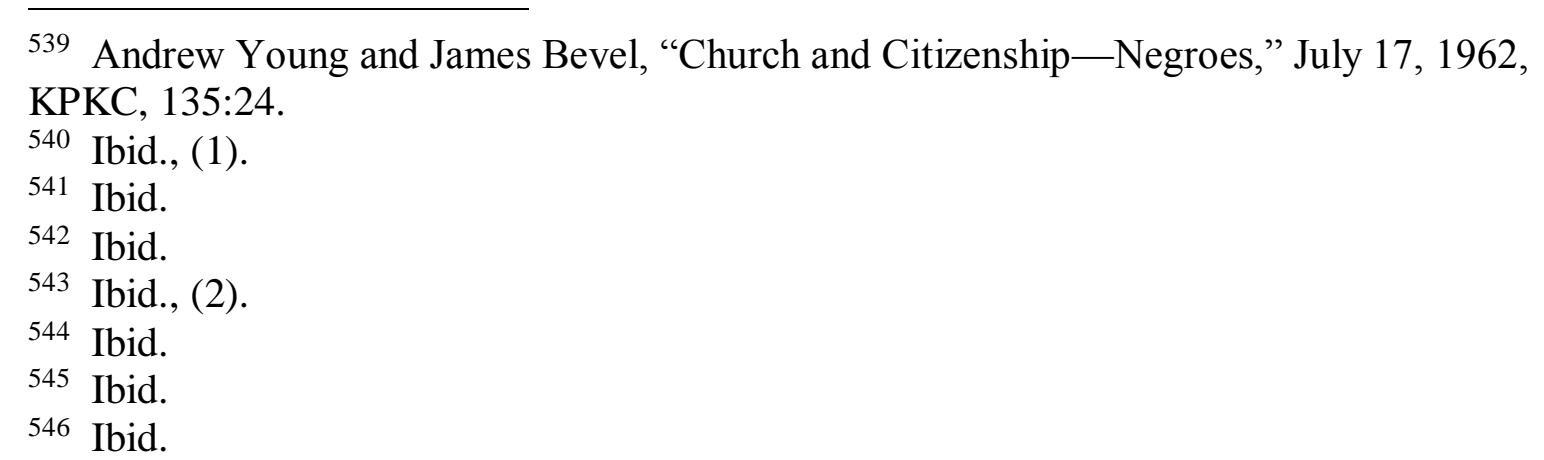


that the role of the church in the civil rights movement is to teach discernment, which seeks to understand "what God wants you to do." ${ }^{, 47}$ Based on this understanding, they interpret their recent civil rights movement of jail-going as a way that discovers and realizes the sonship of the participants. ${ }^{548}$ For gaining a sense of discernment, Young and Bevel maintain that churches have to train and educate their people in how to learn the purposes of God for their nonviolent movement. They quote the words of Paul Tillich: "You get some of the feeling in what Paul Tillich might have been talking about in The Courage to Be, for as a result of being persons, as a result of suffering voluntarily as God's children, you find a new creature with a new courage being born." ${ }^{, 54}$ In order to break down the walls of hostility, Young and Bevel insist on "radical obedience" to God and believe that devoted people will choose a "new form of radical Christian obedience" for a "redemptive community" in the future, as they did with the sit-ins, jail-ins, and Freedom Rides. ${ }^{550}$

In a personal note written while preparing for the WCC meetings, Young stresses that citizenship education is a method of developing the "New Citizen" as a response in faith. ${ }^{551}$ In this note, he states, "Nonviolent movements are schools for the New American." 552 He also highlights the concept of resurrection, which is "the courage to be," as Tillich said, and the "power of love as a moral force capable of overcoming evil." 553 Young suggests that the problems of the twentieth century are "nationalism versus revolution, poverty, color stigma, dehumanization that science and technology brought and world peace with brotherhood." 554 Thus, Young maintains that church people should engage these twentieth century problems as

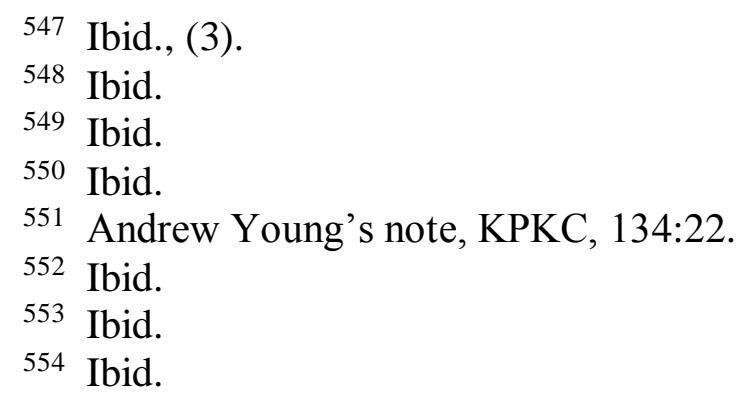


"the sons of God." 555 He states in the note that the citizenship education of Christians should respond to these problems in faith, incarnating the conviction that "Jesus Christ is present in the events of contemporary life." 556 Thus, he insists that African American Christians "must offer more than the freedom to sin as white men have sinned," because they can practice this redemptive work through the nonviolent movement as partners of Jesus's incarnation. ${ }^{557}$ Young and Bevel tried to draw out the Christian values of the voting rights movement that could justify their movement to the worldwide Christian community. Their Christian interpretation of the civil rights movement strongly supported the validity of the movement and challenged American Christians to join it.

One of the closest affiliate organizations of SCLC, the All-Citizens Registration Committee (ACRC) in Atlanta, had tactics for getting churches involved with the voting rights movement. The ACRC organized the Church-Voter Registration Contest, which was supported by SCLC. ${ }^{558}$ The committee sent a letter to all pastors in Atlanta about participating in its voter registration drive. It asked the pastors to enter the contest, organize a special committee in each church, "select one or two roundup dates (April 28, 29, May 4, 5, 1962)" to gather at least twenty-five people who are not registered, "recruit new registrants," and use ten more days for registration. ${ }^{559}$ To recruit church members for voter registration, the ACRC suggested that pastors do the following: persuade their church members to register and to join in the "Christian Citizenship Courthouse Parade"; ask their secretaries to find additional members who are not registered by checking the church's roster; recruit ten people

\footnotetext{
555 Ibid.

556 Ibid.

557 Ibid.

558 All-Citizens Registration Committee, "Christian Citizenship Courthouse Parade," April 24, 1962, KPKC, 139:19.

559 Ibid.
} 
in each church to agree to becoming registered; assemble neighbors who are not church members to join the contest; and notify the registration office about their dates to register. ${ }^{560}$

The contest was supported by "the local sponsoring committee," and the churches were to certify the registrations of the participants. ${ }^{561}$ The committee awarded the participating churches which had new voters. The names of the churches participating in the contest were recorded on the "country-wide Honor Roll on a year-round basis." $" 562$ The ACRC's voting contest run through church committees was a practical tactic of the voting rights drives in Atlanta. As the contest demonstrates, black churches in the South were in all the local areas, and civil rights organizations used to work with churches as centers for organizing people. The ACRC's contest was one of the fastest ways to gather local people to register to vote, and the black churches provided broad contacts with local people.

\section{The Finances of the CEP}

The funding sources of the voting rights movement impacted the expansion of the movement through participation from diverse civil rights organizations. As the Field Foundation's large amount of grant funding enabled SCLC to expand its CEP to a Southernwide level, the CEP was able to help other civil rights organizations operate their own Citizenship School programs through affiliating the work of the full-time field workers of the CEP and the HFS. Fund-raising for the civil rights movement worked as a factor in how civil rights organizations chose the direction of their operating movements. Moreover, the funding sources enabled the civil rights organizations to maintain their voting rights movement, nonviolent tactics, and philosophy of resistance. Along with the importance of achieving the first-class citizenship of African Americans, the funding sources of the voting rights movement were able to centralize the work of diverse civil rights organizations for 
desegregating the voter registration of African Americans.

In February 1961, Lawrence Moore, the executive associate of the Field Foundation, sent a letter to James Wood, the director of public relations of SCLC, requesting a list of "the ten largest donors of the SCLC during 1960" because the foundation needed financial information about SCLC. ${ }^{563}$ As Young describes, Wood replied to Moore about the financial state of SCLC, which was not well organized. ${ }^{564}$ In his letter, Wood explains the financial problem that many small monetary grants came from a large number of donors. Wood lists the following as the ten largest donors; these were diverse religious and nonreligious persons and organizations:

1. Non-partisan Registration Committee c/o Woodford P. Porter, Louisville, Kentucky $\$ 1,000.00$

2. International Brotherhood of Electrical Workers Local Union \#3, New York $\$ 1,000.00$

3. Mr. William Michelson $\$ 3,000.00$

4. (missing) $\$ 1,250.00$

5. Mrs. Anna Sawyer c/o Congress of Racial Equality, New York $\$ 1,000.00$

6. Dr. \& Mrs. Corliss Lamont, New York $\$ 1,000.00$

7. National Laymen's Convention c/o Mr. Alan Jordan, Chicago IL \$783.26

8. Dr. Charles Merrill Commonwealth School, Boston MA $\$ 600.00$

9. Amherst College, MA $\$ 941.01$

10. Baptist Ministers' Conf. of Seattle \& Vicinity, Washington $\$ 625.57^{565}$

After the Field Foundation examined the financial records of SCLC, Maxwell Hahn, the executive vice president of the foundation, sent its committee members' decision about supporting SCLC's CEP program. ${ }^{566}$ In Hahn's letter to Rev. Charles M. Jones, the pastor of the Community Church of Chapel Hill, North Carolina, Hahn stated that "the Field Foundation has voted $\$ 26,500$ for the 12 -month leadership training program which was submitted to the Foundation jointly by SCLC and Highlander." 567 Compared to the ten

\footnotetext{
${ }^{563}$ Lawrence B. Moore to James R. Wood, February 15, 1961, KPKC, 136:4.

564 Young, An Easy Burden, 137; and James R. Wood to Lawrence B. Moore, February 24, 1961, KPKC, 136:4.

565 Ibid.

566 Maxwell Hahn to Rev. Charles M. Jones, April 28, 1961, KPKC, 136:4.

567 Ibid.
} 
largest donors of SCLC in 1960, the Field Foundation became by far the largest donor to SCLC in 1961. King asked the Field Foundation to guarantee "a three to five year commitment" to the CEP in his letter to Hahn in February 1963. ${ }^{568}$ Concerning King's request, Hahn replied to Wesley A. Hotchkiss confirming that the foundation made a decision to grant the CEP $\$ 62,500$ from April 1963 to October $1964 .{ }^{569}$ This large amount of grant funding from the Field Foundation guaranteed solid support for the independent operations of the CEP.

Based on its own rules and philosophy, the Field Foundation did not control or restrain the operations and tactics of the CEP. The Field Foundation examined the value of the CEP program beginning with the experimental years of the Citizenship School on Johns Island, and the foundation's committee was able to foresee the power of the program and its potential to have a Southern-wide impact. ${ }^{570}$ Nonetheless, the Field Foundation wanted the CEP to report their annual expenditures and future activities. ${ }^{571}$ As part of the interracial and philanthropic vision of the foundation, it had responded to the rapid social changes in society because its leaders wanted to be "instruments for contributing private wealth to public purpose." $" 572$ In 1949, Marshall Field expressed his thinking in this way: "I am opposed to giving money on a paternalistic or emotional basis. Such gifts made impulsively without appropriate study..."573 According to the founder's philosophy, the Field Foundation granted funds to "well-established programs designed to improve interracial and intercultural relations over the long range." 574 In 1963, the Field Foundation gave $\$ 1,193,300.00$ to racial

568 Martin Luther King, Jr., to Maxwell Hahn, February 13, 1963, KPKC, 136:6.

569 The amount of the grant was recorded as a higher amount in another document. Maxwell Hahn to Wesley A. Hotchkiss, April 9, 1963, KPKC, 136:6.

570 King to Hahn, February 13, 1963, KPKC, 136:6.

${ }^{571}$ Hahn to Hotchkiss, February 8, 1962, KPKC, 136:5.

572 Maxwell Hahn, "A Review of Its Activities for the Year Ended September 30, 1963," KPKC, 136:6.

573 Ibid., (1).

574 Ibid. 
justice programs out of its total grant funds of $\$ 1,835,209.67 .{ }^{575}$ The foundation gave grants to diverse organizations for various causes, such as the National Congress of American Indians Fund and the Manhattan Society for Mental Health in New York. ${ }^{576}$

During 1963, the CEP was granted $\$ 250,000$, which made it the highest grant recipient of the Field Foundation "among 60 interracial and intercultural relations grants and other grants."577 The second highest grant recipient was the Committee for Welfare, Education and Legal Defense in New York, which received $\$ 100,000 .{ }^{578}$ The NAACP Legal Defense and Education Fund, Inc. was granted $\$ 60,000$ for a two-year period, and the Tougaloo Southern Christian College in Mississippi was given $\$ 15,000$ for organizing a citizenship program. ${ }^{579}$ Miles College in Birmingham was granted $\$ 16,000$ for running an "Internship Program in Citizenship Education in the State of Alabama." 580 The Highlander Research and Education Center in Knoxville, Tennessee, whose name was changed after the Highlander Folk School's struggles with the government of Tennessee, was granted $\$ 40,000$ to educate African American voters. ${ }^{581}$ The Voter Education Project of the Southern Regional Council, which was a research-oriented organization, was given $\$ 75,000$ from the Field Foundation. ${ }^{52}$ The reason why the foundation gave its greatest grant to the CEP was its highly developed training programs and its effectiveness - the CEP had established over 150 local citizenship schools through its five-day and six-month workshops for training local leaders who could set up local citizenship classes, which they did in "113 counties in Deep South states." 583 Thus, from this record of the Field Foundation, the CEP was the major

\footnotetext{
575 Ibid., (2).

576 Ibid.

577 Ibid.

578 Ibid.

579 Ibid., (3).

580 Ibid.

581 Ibid.

582 Ibid.

583 Ibid., (1).
} 
focus of its efforts for racial justice. The Field Foundation's giving demonstrates the unique achievements of the CEP for the voting rights movement and clarifies that the CEP was the center of voting rights activities among civil rights organizations.

Based on the solid grants from the Field Foundation, the budget of the CEP could be used to hire full-time supervisors and half- and part-time field workers and to establish citizenship schools in counties across the South. Even though there was a problem with clearly reporting the expenditures of the CEP to the Field Foundation and its affiliates, the CEP kept detailed financial records. ${ }^{584}$ From July 1961 to June 1962 , the CEP received $\$ 55,500.00$ in grant money from the Field Foundation. It spent $\$ 7,666.66$ for Young's salary, $\$ 6,500.00$ for Clark's and $\$ 4,500.00$ for Cotton's. ${ }^{585}$ In sum, the total expenses were $\$ 55,784.16$, and $\$ 1,583.03$ remained as an unexpected balance. ${ }^{586}$ In SCLC's financial report from 1960 to $1961, \$ 33,952.52$ was spent for staff salaries, with its total income being $\$ 159,163.91{ }^{587}$ Comparing the $\$ 18,666.66$ the CEP used for staff salaries from 1961 to 1962 to SCLC's total expenses for salaries, the CEP had a strong financial budget for operating a Southern-wide program.

From July 1, 1962 to June 30, 1963, the CEP had larger expenditures than the previous fiscal year. Young received $\$ 9,200.00$ for his salary, $\$ 382.48$ for hospitalization, $\$ 1,012.00$ for an annuity fund for Congregational ministers, and $\$ 6.24$ for social security. ${ }^{588}$ Clark received $\$ 7,500.00$ for her salary, $\$ 268.29$ for hospitalization, $\$ 184.38$ for social security, and $\$ 862.50$ for her retirement fund for lay workers. ${ }^{589}$ The CEP paid Cotton

\footnotetext{
584 Garrow, Bearing the Cross, 233.

585 United Church Board for Homeland Ministries, "SCLC Field Foundation Project: Application of Funds," July 1961-June 1962, KPKC, 136:11.

586 Ibid.

587 SCLC, "Newsletter Vol. 1," February 1962, KPKC, 122:20.

588 United Church of Christ, "Citizenship Education Program in the South-Field Foundation Statement of Expenditure," July 1, 1962-June 30, 1963, KPKC, 136:12. 589 Ibid.
} 
$\$ 6,000.00$ for her salary, $\$ 161.44$ for hospitalization, $\$ 188.41$ for social security, and $\$ 690.00$ for her retirement fund for lay workers. ${ }^{590}$ The CEP spent $\$ 24,694.01$ on the operation of local schools, $\$ 895.78$ for guest speakers and consultants for workshops, $\$ 1,187.74$ for room and board, $\$ 8,680.88$ for staff travel (recruiting, supervising, etc.), $\$ 11,874.55$ for student travel, $\$ 5,216.95$ for educational materials (citizenship booklets, pamphlets, etc.), $\$ 2,186.77$ for supplies, and $\$ 825.24$ on miscellaneous expenses. ${ }^{591}$ Thus, its total expenditures for the year came to $\$ 94,637.84 .{ }^{592}$

From 1965 onward, the CEP had an increasing need for funds because there were more students, teachers, and local schools in the eleven states of the South than in previous years. The CEP reported that the operation of the program required at least $\$ 200,000$ a year, or, strictly speaking, $\$ 177,908$ per year and $\$ 889,540$ over a five-year period. ${ }^{593}$ Cotton, who succeeded Young as the executive director of the CEP in 1964, reported the 1967-1970 proposed budget for the CEP to the Field Foundation. For the 1967-1968 fiscal year budget, Cotton requested $\$ 9,600$ for the director's salary. ${ }^{594}$ The total amount of budget requests for the 1967-1968 fiscal year was $\$ 174,900 .^{595}$ Cotton's proposed budget for fiscal year 19681969 was $\$ 193,100$, and for fiscal year $1969-1970$, it was $\$ 206,200 .^{596}$ These financial reports demonstrate that the CEP had grown and expanded across the South during these years. To respond to the various needs of local communities, the CEP had successfully achieved its goal of training grassroots leaders, even after the Voting Rights Act of 1965 was established.

\footnotetext{
590 Ibid.

591 Ibid.

592 Ibid.

593 Citizenship Education Program, “Citizenship Education Proposal for 1965-1970,” 1965, KPKC, 151:24.

594 Dorothy Cotton, "Proposal for Citizenship Education Program to the Marshall Field Foundation," 1967, KPKC, 151:27.

595 Ibid.

596 Ibid.
} 
The CEP worked in harmony with other affiliated civil rights organizations, and this was one of the reasons why the CEP was successful from its initial years. In 1962, the Montgomery Improvement Association, the Southeast Georgia Crusade for Voters, the Virginia Christian Leadership Conference, and the Nashville Student Central Committee were affiliated with the CEP's voter registration drives for the "Southern grass-roots character of our membership." 597 As the Citizenship School of the CEP expanded across the South, there were many organizations that hoped to affiliate with the CEP. Using the unmatched tactics of the Citizenship School for training grassroots leaders, the CEP could train almost all the voting rights workers of CORE, the NAACP, SNCC, and COFO. ${ }^{598}$ Moreover, SCLC had about 180 affiliates in 1964 and 270 in 1968, and most of them asked SCLC staff to visit their areas to help them set up CEP workshops. ${ }^{599}$ In Mississippi, the CEP cooperated with the MFDP to establish citizenship schools for local voting rights education. In Alabama, the Freedom Army, a statewide affiliated organization, helped the CEP initiate voting rights education with its strong support. ${ }^{600}$ SCLC took on a summer project for voter registration drives, called the Summer Community Organization and Political Education project (SCOPE), with volunteers from affiliated organizations. The Citizenship School oriented and developed the voting rights movement that diverse civil rights organizations joined; thus, the organizations had the same interests and goals for desegregating voters. As Young demonstrated, the Citizenship School diminished the

\footnotetext{
597 SCLC, “The S.C.L.C. Voter Registration Prospectus for 1962," KPKC, 138:17.

598 Andrew Young to Wesley Hotchkiss, July 20, 1964, KPKC, 136:14.

599 Ibid.; The Citizenship Education Program, "Itineraries 1961-1962," KPKC, 136:23; and SCLC, "Dr. King and the SCLC_Powerful Action for Change," March 31, 1968, http://www.crmvet.org/docs/6803_sclc_4change.pdf.

600 The Citizenship Education Program, "Reports to Foundation,” July 1962-June 1964, KPKC, 137:2.
} 
different identities of the civil rights organizations while they worked together on voting rights education. ${ }^{601}$

The CEP defined "the role of affiliates" by requiring affiliates to direct their own Citizenship School programs and correctly implement them according to the CEP's guidelines. ${ }^{602}$ Graduates from the CEP's Dorchester Center workshops mostly worked for voter registration in diverse civil rights organizations that were affiliates of the CEP. ${ }^{603}$ In 1962, the SRC operated the Voter Education Project (VEP) that the Kennedy administration endorsed, and it was funded by the Taconic, Field, New World, and Stern Family Foundations. The VEP worked on researching and analyzing the patterns of African Americans' voting and supported the voter education programs of SNCC, SCLC, CORE, the National Urban League (NUL), and the NAACP. ${ }^{604}$ The VEP operated a budget of about $\$ 260,000$ per year and annually granted $\$ 11,500$ to SCLC. ${ }^{605}$ The VEP annually granted $\$ 8,625$ to CORE, $\$ 6,373$ to SNCC, and $\$ 17,250$ to the NAACP. ${ }^{606}$ These grants of the VEP to five affiliates of the CEP means that these major voting rights organizations were sharing their financial information and social activities with each other. Sharing the tactics of the Citizenship School and the grants of the VEP, the close relationships between the CEP's affiliates made it possible to maximize the effectiveness of the voting rights movement in the Birmingham Campaign, the Mississippi Summer Project, and the Selma to Montgomery marches.

The CEP was able to take over the Southern-wide voting rights movement through developing its funding sources, its tactics for the grass roots, and its Christian philosophy for

\footnotetext{
601 Young to Hotchkiss, July 20, 1964, KPKC, 136:14.

${ }^{602}$ Martin Luther King, Jr., KPKC, 136:9.

603 The Citizenship Education Program, "Reports to Foundation,” July 1962-June 1964, KPKC, 137:2.

${ }^{604}$ Leslie W. Dunbar, “Annual Report-Voter Education Project 1962-1963,” KPKC, 138:9. 605 Ibid.

606 Ibid.
} 
appealing to African American churches. The grants of the Field Foundation allowed the CEP to hire large numbers of field workers who could develop the citizenship schools in local communities and affiliate with other civil rights organizations. The grassroots leadership style that the Christian women leaders developed could be applied by local civil rights activists who were previously hidden under the hierarchical leaders, allowing them to raise their voices. This leadership transition and the success of the Citizenship School program created a new phase of the civil rights movement that was led by new and young leaders, women leaders, and grassroots activists. The grassroots leadership of the Citizenship School empowered the diverse organizations of the civil rights movement to centralize for desegregating the voter registration of African Americans from 1961 to 1965. 


\section{Chapter Three}

\section{The Citizenship School's Women Leaders' Christian Thoughts and Practices for Grassroots Leadership}

I have been a member of the African Methodist Episcopal (A.M.E.) church all of my life. My father's brother-in-law was pastor of the A.M.E. church in Pine Level, Alabama. The denomination became known as "The Freedom Church" during the abolitionist movement. It was the spiritual home of many well-known black persons in our history before civil rights. They include Bishop Richard Allen (the founder of the A.M.E. church), Frederick Douglass, Harriet Tubman, Sojourner Truth, and others. They all were strongly rooted in the A.M.E. church. ${ }^{607}$

The grassroots leadership tactics of the Citizenship School were fundamental to transitioning the leadership structure of the civil rights movement and desegregating voting rights. This transition in the leadership structure depended on the grassroots women leaders who had been working for the local people and had discovered the core value and purpose of the civil rights movement. Septima Clark was the inventor of the Citizenship School, and Robinson was the essential developer of it into the local citizenship schools and into the citizenship education programs of the NAACP, SCLC, SNCC, and COFO. Cotton and Ponder were the local leaders who expanded the local power of grassroots people to struggle for and find their own rights and freedom. Hamer and Nash were the freedom fighters who encouraged the grassroots people to find the reason why they had to fight against evil social structures, because they could not live with the segregated social system as human beings. These women leaders who were the major reformers of the civil rights movement for grassroots people depended on their religious faith and experiences in pursuing human rights and freedom. Their Christian faith and experiences were also the major contributions to the expansion and development of the grassroots impact on the civil rights movement. This

607 Rosa Parks with Gregory J. Reed, Quiet Strength: The Faith, the Hope, and the Heart of a Woman Who Changed a Nation (Grand Rapids: Zondervan Publishing House, 1994), 32. 
chapter delves into the Christian experiences and beliefs of the women grassroots leaders and analyzes how their religious faith contributed to the success of the voting rights movement.

Moreover, just as SCLC male clerical leadership structure could be considered from the perspective of its leaders' black church tradition, the women leaders' church denominational traditions, such as the context of black Baptist women, should be examined. As Young and Clark witnessed, the Southern Baptist black church tradition was the important factor that controlled the thoughts of the senior male leaders of SCLC ${ }^{608}$ Young observes in his autobiography, “That [women's position in SCLC] set me apart from the more authoritarian Baptist-style of most of SCLC's senior staff." ${ }^{\prime 69}$ Clark witnesses in her memoir, "Like other black ministers, Dr. King didn't think too much of the way women could contribute."610 The different church denominational backgrounds and religious practices impacted the pursuit of different leadership structures by SCLC's male leaders and the women civil rights leaders who were affiliated with SCLC. The civil rights movement of African American women could be considered as the movement of Christian women organizations, as Evelyn Brooks Higginbotham and Bettye Collier-Thomas clarify in their historical works. In her Righteous Discontent, Higginbotham observes, "The zealous efforts of black women's religious organizations to transform certain behavioral patterns of their people disavowed and opposed the culture of the "fold" - the expressive culture of many poor, uneducated, and "unassimilated" black men and women dispersed throughout the rural South or newly huddled in urban centers." "611 Collier-Thomas insists in her Jesus, Jobs, and Justice, "It was through the collective efforts of African American church women and their organizations, and the work of individual black women in race-specific, gender-specific,

\footnotetext{
608 Young, An Easy Burden, 139.

609 Ibid.

${ }^{610}$ Clark, Ready from Within, 79.

611 Evelyn Brooks Higginbotham, Righteous Discontent: The Women's Movement in the Black Baptist Church, 1880-1920 (Cambridge: Harvard University Press, 1993), 15.
} 
biracial, and interracial associations that the struggle for the rights of women and blacks was conducted."612 Baker's belief in grassroots leadership also originated from her experience of the Christian charity movement of black Baptist women's associations. ${ }^{613}$ This chapter analyzes how the Christian women leaders' grassroots movement differed from the social movement of the clerical male leaders due to their experience of black churches' denominational organizations of women.

\section{The Black Baptist Women's Tradition}

Ella Baker

On October 23, 1959, Ella Baker submitted her project for establishing the voting rights education program in SCLC to SCLC committee on administration. In this memorandum, Baker insists on the emergent need for education programs in SCLC to increase voter registration by using church connections within the African American community. In the memorandum, she suggests that SCLC

stimulate religious bodies, civic and fraternal organizations (composed of women, especially) to utilize the facilities for reducing functional illiteracy among Negroes. . . It was not my idea that S.C.L.C. should conduct classes, but that we could interest such groups as the Women's Baptist Convention, the National Council of Negro Women, and national college sororities in such projects. . . On the other hand, the literacy project could provide a "respectable" channel for helping the cause without too close identification with more militant aspects of the struggle. The literacy project could well serve as the basis for calling a Southwide meeting of women, as we proposed before. ${ }^{614}$

Baker does not comment about the HFS in this memorandum; however, she wanted to expand the voter registration drives through developing education systems with the help of church women's organizations. Baker's suggestion demonstrates her understanding of the abilities of Christian women's organizations to develop the voting rights movement at a

612 Bettye Collier-Thomas, Jesus, Jobs, and Justice: African American Women and Religion (New York: Alfred A. Knopf, 2010), xxiii.

613 Collier-Thomas and Franklin, eds., Sisters in the Struggle, 45.

614 Ella Baker, "Memorandum" to Committee on Administration of the SCLC, October 23, 1959, KPKC, 32:43. 
Southern-wide level. Vivian Carter Mason, who was the third president of the National Council of Negro Women (NCNW), temporarily helped Baker's Crusade for Citizenship set up plans for a voting rights workshop in $1958 .{ }^{615}$ Concerning her plan for working with the Women's Baptist Convention, it coincided with Baker's religious background, which was "the black Baptist women's missionary movement." $" 616$

Baker was born in 1903 and had grown up in the black Baptist church tradition in Norfolk, Virginia, and mostly in Littleton, North Carolina. Her maternal grandfather was a preacher who founded the Roanoke Chapel Baptist Church, which ministered to and cared for the community by addressing such concerns as health and food. ${ }^{617}$ Baker's maternal grandfather, Mitchell Ross, took on an itinerant mission for preaching and helping with physical needs in the local community along with Baker. ${ }^{618}$ In her interview with John Britton in 1968, Baker witnessed that her first influence, which introduced her to participation in the civil rights movement, was her religious family background of helping people in the community, as her maternal grandfather did. ${ }^{619}$ Rev. Ross had a contract with a plantation to farm crops to feed the poor people in the community. ${ }^{620}$ He preferred to preach like a teacher and did not allow his congregation to shout while the preachers were preaching in his church. ${ }^{621}$ Even though Rev. Ross died when Baker was seven years old, she was strongly impacted by him to help with the needs of community people. ${ }^{622}$ Because of Rev. Ross's special commitment to help local people, Baker remembered that he was not like the

\footnotetext{
615 See page 42.

${ }^{616}$ Collier-Thomas and Franklin, Sisters in the Struggle, 44.

617 Grant, Ella Baker, 8; and Ross, Witnessing \& Testifying, 35.

618 Ross, 36.

619 John Britton, “Oral History/Interview Ella Baker 1968," in The Civil Rights

Documentary Project, 1968, http://www.crmvet.org/nars/baker68.htm\#baker68_family.

620 Ibid.

621 Ibid.

622 Ibid.
} 
common black Baptist preachers and too unusual to accept impractical religious authority. ${ }^{623}$ As she had trouble with the hierarchical clerical leaders of SCLC, Baker's favor for nonauthoritarian community leaders corresponded with her respect for her maternal grandfather.

Along with this religious tradition of Baker's family, her mother, Georgianna (people called her Anna) Baker, taught at an abandoned school, served as a midwife for poor pregnant women, and cared for the health of poor families ${ }^{624}$ In her interview, Baker described that her mother's Christian charity works were done in emulation of Rev. Ross's life. ${ }^{625}$ Mrs. Baker worked at the meetings of the Baptist Missionary Union and at the local Baptist women meetings that were founded by Nannie Helen Burroughs. ${ }^{626}$ Her speech "The Needs of the Hour and How to Meet Them" at the North Carolina Baptist Women's Union State Convention in 1924 demonstrates that Mrs. Baker was an influential leader of the meetings of the Baptist women. ${ }^{627}$ At this convention, Ella Baker also gave a speech. She often participated in Christian women's meetings with her mother. ${ }^{628}$ Mrs. Baker dedicated her life to helping her poor neighbors by providing them food, health care, midwife, and funeral services. ${ }^{629}$ Baker's family tradition of helping people in the community was reflected in her civil rights movement work, which focused on the grassroots movement. Until she attended Shaw University, which was founded within the Baptist tradition, Baker's religious background was the Southern black Baptist church in which black Baptist women's missionary work was practiced in her early life.

Ibid.

${ }^{624}$ Grant, Ella Baker, 13; and the New York Public Library, "Biographical Sketch," in Ella Baker Papers 1926-1986, http://archives.nypl.org/uploads/collection/pdf_finding_aid/scmmg630.pdf.

625 Britton, "Oral History."

${ }^{626}$ Ross, Witnessing \& Testifying, 33.

627 Grant, 19; and Ross, 34.

${ }^{628}$ Grant, 19.

${ }^{629}$ Ross, Witnessing \& Testifying, 33. 
Baker's awareness of the necessity of social work for grassroots people originated in her experiences of black Baptist women's organizations. Until she began attending college, Baker had participated in the social activities of the Women's Convention (WC) with her mother. Baker had the same church denominational background as King - the African American Baptist church — and during the civil rights movement era, King and the senior leaders of SCLC belonged to the National Baptist Convention (NBC), which had been founded in 1895 and was the largest church organization of African Americans in the United States at the time. ${ }^{630}$ Baker's religious experiences differed from King's in that she was involved in the social activities of Rev. Ross and Mrs. Baker in the church community of a plantation, while King mostly grew up in the urban area of Atlanta, and his maternal grandfather and his father were prominent Baptist pastors in the South. ${ }^{631}$ Even though the WC was an auxiliary organization of the NBC, the WC could have independent activities that were different from the activities of men in the NBC. The social activities and women's independent spirit of the WC were the religious background of Baker and other women civil rights leaders.

The WC was a united convention of black Baptist women that was founded in 1900. There had been many efforts by local women's missionary organizations to support and found colleges that focused on educating black professionals in several states. ${ }^{632}$ The American Baptist Home Mission Society (ABHMS) and its auxiliary organization of women, the Women's American Baptist Home Mission Society (WABHMS), founded several colleges in the South, such as the Atlanta Baptist Female Seminary (the former name of Spelman College), Atlanta Baptist College (the former name of Morehouse College), Shaw

630 King, The Papers of Martin Luther King, Jr., Vol. 4, 17-18; and King, The Papers, Vol. 1, 103-104.

631 Martin Luther King, Sr., Daddy King: An Autobiography (New York: William Morrow, 1980), 91-97.

${ }^{632}$ Higginbotham, Righteous Discontent, 150-164. 
University in North Carolina, and the Nashville Institute. ${ }^{633}$ These women Baptist organizations also helped local poor people through establishing "mothers" training schools." ${ }^{634}$ The training schools promoted self-help for local African Americans through teaching health care, housekeeping, and child education. ${ }^{635}$ Even though the ABHMS and WABHMS were mainly organized by white Baptists in the North, black Baptist churches in the South quickly participated with the founding of Spelman College and Morehouse College during the 1880 s. $^{636}$ With aggravated racial segregation and violence and an increased awareness of the self-help spirit of African Americans during the 1890s, black Baptists realized the need for promoting the "self-determination" of black Baptists through activities independent from the white Baptists. ${ }^{637}$ With the motto of the self-help spirit of the black Baptists, the NBC was organized in 1895, and several black Baptist women organizations in the Southern states were initiated, such as “the Baptist Women's Educational Convention, the Women's Baptist Educational and Missionary Convention and the Woman's Baptist Missionary and Educational Association."638 At the state level, these black Baptist women's conventions were called "Women's State Conventions," and they supported the colleges and schools that were controlled by African American women. ${ }^{639}$

The NBC, which was the largest black church denomination, had 1,864,000 members and spent $\$ 174,418.57$ to support schools for African Americans in its initial year. ${ }^{640}$ This organization had separated from white Baptist churches because white Baptists did not fully support racial integration, and African Americans needed independence in educating their

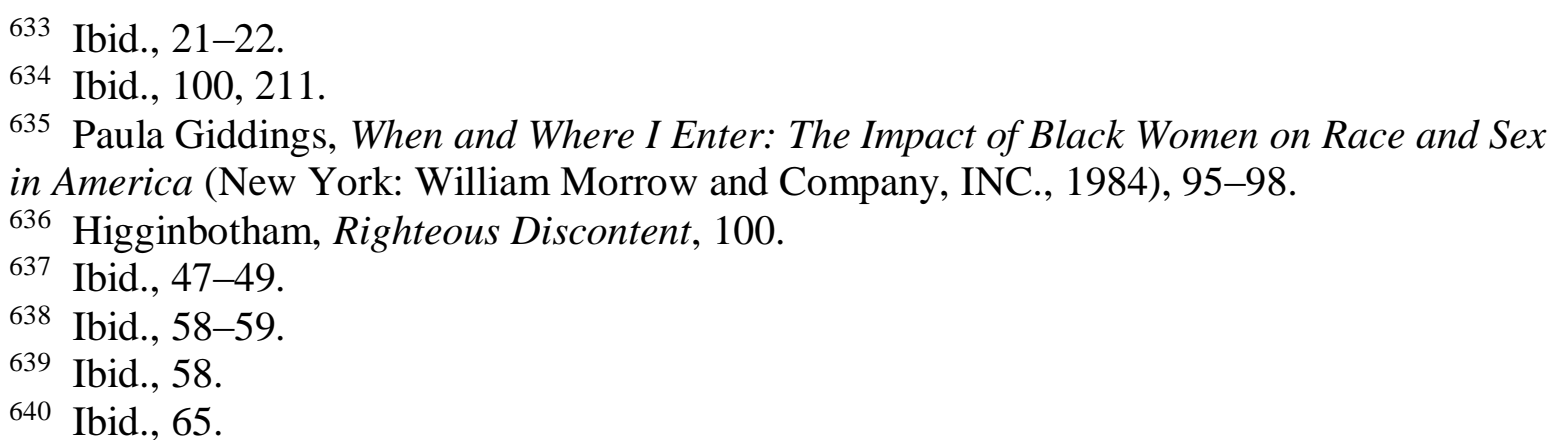


people, without white people controlling their education. The WC was also initiated because black Baptist women needed to educate their children without the controls of the hierarchical male ministers and church leaders who did not allow women to participate in the NBC as leaders of the convention. ${ }^{641}$ With the powerful speech of Nannie Helen Burroughs at the NBC meeting, the WC was able to initiate and organize the women's independent dynamics of a "righteous discontent" within a socially unequal system. ${ }^{642}$ As Burroughs expressed in her speech, the black Baptist women had frequently demanded that the NBC establish independent committees of the women's organization.

The WC was an auxiliary to the NBC, however, it had independent finances and committee members, who were the representatives of twenty-six states. ${ }^{643}$ The racial independence movements of the WC and NBC were in accordance with the sudden increase of black Baptist members from the 1890s to the 1910s. In 1890, the black Baptist Church's membership was $1,349,000$, a number which would double in the early twentieth century because an increase in the black independence movement during the next decade of Emancipation encouraged black Christians to establish church denominations independent from the former white anti-abolitionist churches. ${ }^{644}$ The WC mainly worked for the local poor and established the National Training School for Women and Girls to promote the selfhelp of poor African Americans and to reach these people in every local area. ${ }^{645}$ Thus, the

${ }^{641}$ Ibid., 68. There also had been troubles with having independent leadership of the WC because the NBC leaders had frequently forbidden the women leaders to be committee chairs of the WC. See Collier-Thomas, Jesus, 134.

642 The "righteous discontent" was quoted from Burroughs's speech. See Higginbotham, Righteous Discontent, 150.

${ }^{643}$ Ibid., 157. The WC's auxiliary position to the NBC was closely related to the NBC's restriction of ordaining female ministers. The first woman pastor was ordained by the NBC in 1965. See J. H. Jackson, A Story of Christian Activism: The History of the National Baptist Convention, U.S.A., Inc. (Nashville: Townsend Press, 1980), 144-145; Collier-Thomas, Jesus, 118; and C. Eric Lincoln and Lawrence H. Mamiya, The Black Church in the African American Experience (Durham: Duke University Press, 1990), 296.

${ }^{644}$ Higginbotham, Righteous Discontent, 93.

645 Ibid., 187, 212. 
religious tradition of the WC was founded on the black Baptist women's independent movements for education and the well-being of local African Americans. The WC's efforts in pursuing women's "self-determination" and Christian charity for local people were part of the religious background of Baker's civil rights movement for grassroots people. ${ }^{646}$ As Baker was influenced by her mother's Christian charity activities, most WC leaders and members were the children of the local poor and working classes, and their focus on helping grassroots people was the major difference of the WC from other social organizations of the United States at the statewide level. ${ }^{647}$

Baker's experience with the WC's Christian charity movement continued into her activities in the Young Negroes' Cooperative League (YNCL), the Works Progress Administration (WPA), and the YWCA. The YNCL was the first organization that Baker became involved in civil rights activities with when she stayed in New York City. ${ }^{648}$ It was a buying club for the welfare of African Americans who needed food and health care, and Baker was able to practice grassroots leadership in the organization. Baker also worked for the WPA's Workers Education Project (WEP) as an educator. This organization was meant to create job opportunities using government funds. The WEP had nationwide offices for employing workers, artists, and writers, including African American artists. ${ }^{649}$ This project was designed to overcome unemployment during the Great Depression and had a program for educating workers and teachers about political issues. ${ }^{650}$ In addition, Baker joined the

646 Ibid., 151; and Collier-Thomas, Jesus, 123.

647 Collier-Thomas, Jesus, 123-124.

648 Britton, "Oral History/Interview Ella Baker 1968."

${ }^{649}$ Barbara Ransby, Ella Baker and Black Freedom Movement (Chapel Hill: University of North Carolina Press, 2003), 92.

650 Ibid., 93. The WPA programs during the Depression changed Baker's understanding of success, which was to develop the economic level of a mass of people rather than that of an individual person. See Kevin K. Gaines, Uplifting the Race: Black Leadership, Politics, and Culture in the Twentieth Century (Chapel Hill: The University of North Carolina Press, 1996), 251. 
YWCA during her years at Shaw University, and her participation in the YWCA in Harlem, New York, provided her with opportunities to meet lifetime civil rights colleagues, such as Pauli Murray, who was a feminist, the civil rights leader of the NAACP, and the first African American woman minister in the Episcopal Church, and Dorothy Height, who was the leader of the National Council of Negro Women and the YWCA. ${ }^{651}$ Baker also worked for the 135th Street library in Harlem to coordinate the African American culture programs. ${ }^{652}$ The early social justice work of Baker included teaching and helping grassroots people, and these efforts were continuous with her engagement in the WC's Christian charity movement with her mother and with the local Christian self-help plantation with her maternal grandfather.

The WC began to encourage black Baptists to fight for voting rights in the 1920s. After women in the United States gained their voting rights in 1920, Burroughs insisted that African American women should have equal rights just like the white women who had gained voting rights. The WC's leaders, such as Burroughs and Gertrude Rush, organized the WC's Suffrage Department, which insisted on the importance of Christian women's suffrage. ${ }^{653}$ As the chair of the Suffrage Department, Rush highlighted that Christians' voting could practice the reality of the gospel and change the racially segregated system that worked against African American women, including poor health care, lack of job opportunities, and lynching by local racists. ${ }^{654}$ The political movement of the WC originated with the deep realization of the disfranchised situation of African American women. The WC tried to expand its efforts to develop Christian women's voting rights by cooperating with other non-religious and interdenominational women's organizations, such as the National Association of Colored

651 Ransby, Ella Baker, 71.

652 Ibid., 70.

${ }^{653}$ Collier-Thomas, Jesus, 259.

654 Ibid. 
Women (NACW), the AME's Women's Mite Missionary Society, and the YWCA. ${ }^{655}$ Moreover, the WC, which had the largest membership and geographically the most diverse communities, could develop strategies for educating and training women to participate in politics through suffrage. ${ }^{656}$ To highlight the justification for their political participation, women leaders of the WC tried to bring "righteous guidance" to women's social activities by using biblical concepts of human equality and freedom. ${ }^{657}$ As the Christian women of the WC had fought for human rights based on their faith in these God-given rights, Baker's enthusiasm for equality and freedom for African Americans had always originated in her faith in the biblical truth. Baker frequently emphasized in her speeches, "You know, I always like to think that the very God who gave us life, gave us liberty. And if we don't have liberty it is because somebody else has stood between us and that which God has granted us." 658 Burroughs of the WC encouraged Baptist women to establish voting rights clubs in each local church. ${ }^{659}$ The leaders of the WC intended that their churches be places for promoting the political rights of Christians. Associating with the WC and other Christian women's organizations, the YWCA was the one of the greatest contributors to the initiation of the civil rights movement through the groundwork of women's organizations during the early twentieth century. ${ }^{660}$ The YWCA also participated with the voting rights movement of African Americans through their nationwide branches. ${ }^{661}$ Before she began the voting rights

655 Ibid., 292; and Karen A. Johnson, Uplifting the Women and the Race: The Educational Philosophies and Social Activism of Anna Julia Cooper and Nannie Helen Burroughs (London: Routledge Publishing, 2000), 149.

${ }^{656}$ Collier-Thomas, Jesus, 288.

657 Ibid., 289.

658 Ella Baker, “Address at the Hattiesburg Freedom Day Rally,” January 21, 1964, http://voicesofdemocracy.umd.edu/ella-baker-freedom-day-rally-speech-text/; and Ross, Witnessing, 49-51.

${ }^{659}$ Higginbotham, Righteous Discontent, 227.

660 Collier-Thomas, Jesus, 368.

661 Ibid., 452; and Dorothy I. Height, Open Wide the Freedom Gates: A Memoir (New York: Public Affairs, 2003), 162. 
movement in SCLC, Baker had experienced the impact of the nationwide connection of Christian women's organizations, such as the WC and the YWCA, which had worked for African Americans' voting rights and social welfare. When she suggested that SCLC develop literacy classes through the nationwide connections of the WC, Baker had learned from these strong Christian women's organizations about the reality and possibilities of grassroots leadership for the civil rights movement. ${ }^{662}$ Most of all, in contrast to the senior male leaders of SCLC who were Baptist ministers, her religious background with the WC led Baker to take the different focus of empowering grassroots people and promoting the independence of women from the leader-centered civil rights movement of the clerical male leaders.

\section{Dorothy Cotton}

Sharing the religious background of the black Baptist church, Dorothy Cotton began her civil rights work in the Gillfield Baptist Church in Petersburg, Virginia, whose pastor was Reverend Wyatt Tee Walker. Born in 1930, Cotton had to struggle with the hopeless condition of her family in Goldsboro, North Carolina. ${ }^{63}$ Cotton's mother died when she was only three, and her father, Claude Daniel Foreman, frequently left his children alone. When she was a little child, Cotton sometimes followed her father to work on the tobacco plantations. ${ }^{664}$ Foreman did not attend church and sometimes beat his children severely. ${ }^{665}$ Cotton had to do housekeeping work for white families from the time she was a teenager, and her wages helped her family and paid her tuitions for schools and colleges. ${ }^{666}$ Cotton's experience of poverty in African American communities led her to open her eyes to finding ways of overcoming the problems of local poor people. When she attended Dillard High School, Cotton met Rosa Gray, who taught her English classes. Gray enlightened Cotton and

\footnotetext{
662 See the page 182.

663 Cotton, If Your Back's Not Bent, 25.

664 Ibid., 27.

665 Ibid., 28-29.

666 Ibid., 33-34.
} 
gave her the motivation to be an English teacher through her self-help efforts. ${ }^{667}$ Gray guided Cotton to get a college education by working at campus jobs, and Cotton was able to go to Shaw University with self-support from her housekeeping of the president's house. Through meeting the teacher Gray, Cotton realized the important role of education and believed that it was "divine intervention" in her life to help her overcome her hopeless family background. ${ }^{668}$ When she transferred from Shaw University to Virginia State College following the presidency of Dr. Robert Prentiss Daniel, Cotton joined the Student Christian Association, which was a student department of the YWCA. This association provided her with opportunities to consider social issues, to take a break from busy housekeeping at the president's house, and to meet other students from diverse colleges. ${ }^{669}$ When she listened to Dr. Vernon Johns's speech as the special guest speaker at the Virginia State College's chapel service, Cotton was impressed by him; he was the pastor before King at the Dexter Avenue Baptist Church. ${ }^{670}$ Through talking with Dr. Johns, Cotton realized that she needed to act against American apartheid. ${ }^{671}$ Through these interactions with church people and organizations, Cotton was able to act on her civil rights concerns when she joined the Gillfield Baptist Church. Reverend Walker worked for the Petersburg branch of the NAACP, the Petersburg Improvement Association, and the Congress of Racial Equality (CORE). He encouraged his church people to fight against racism in their community. ${ }^{672}$ Cotton began working together with Walker for social changes in $1954 .{ }^{673}$ The church and the town of

667 Ibid., 46

668 Ibid., 39. Cotton described the teacher Gray as a woman who cared for her like a mother. See the Civil Rights History Project, U.S., Joseph Mosnier, and Dorothy F. Cotton, Dorothy Foreman Cotton Oral History Interview Conducted by Joseph Mosnier in Ithaca, New York, 2011-07-25. Ithaca, New York, July 25, 2011. Video. Retrieved from the Library of Congress, https://www.loc.gov/item/afc2010039_crhp0040/, (Accessed November 3, 2017). 669 Cotton, If Your Back's Not Bent, 54.

670 Ibid., 63.

671 Ibid., 64

672 Ibid., 74.

673 Ibid., 75. 
Petersburg were relatively small, and Cotton and Walker easily organized people to respond to social problems. They paid attention to the Montgomery Bus Boycott, and being inspired by the boycott, they protested against the public library's segregated entrance for colored people. They also supported the students' sits-ins at the Woolworth's store lunch counter. Cotton helped Rev. Walker as his secretary, and they tried to train young people in their church to do mass meetings in Petersburg. ${ }^{674}$ Walker met King at a Baptist church conference and invited him to the Gillfield Baptist Church. When King visited to give a speech to the Gillfield Baptist Church and talked with the church people, he was very impressed by the church members' activities of picketing, their workshops, and their success with desegregating the public library. ${ }^{675}$ King asked Walker to come to Atlanta and work for SCLC, and Walker accepted his invitation on the condition that he could bring along his coworkers in the Petersburg movement, Jim Wood and Dorothy Cotton. When they moved to SCLC headquarters in Atlanta, Cotton asked her husband, George Cotton, for permission to leave home for about three months. ${ }^{676}$ However, Cotton ended up staying in Atlanta twentythree years and dedicating her life to civil rights. Before King invited her to SCLC, Cotton had been ready to train local people to protest for their civil rights as she had experienced in her church life. In her autobiography, Cotton confesses about her religious life in the Gillfield Baptist Church, "My church life had become so much more than the Sunday-morning service. Actually, all the protest activity I had become heavily involved in made church involvement more meaningful; the message of the sermons, though always enjoyable, now had increased relevance to what we were actually living through." ${ }^{677}$ Her church life

${ }^{674}$ In her interview, Cotton testified that the word of mass meetings was generally used in Petersburg to advertise protest activities and that mass meetings were a common phenomenon in almost all small towns during the civil rights movement. See Civil Rights History Project. 675 Ibid.

676 Ibid.

677 Cotton, If Your Back's Not Bent, 85. 
provided her with the original meaning and relevance of the civil rights movement for her. Cotton's religious life made a crucial contribution to the development of her philosophy of social justice and to her receiving King's invitation to join SCLC. Thus, Cotton's church life in the Gillfield Baptist Church was the origination of her lifetime dedication to civil rights through the social activities of SCLC.

The heritage of the African American Baptist church, which had pursued the inseparable goals of social and denominational independence, had been Cotton's religious background. Cotton's father was an anti-church person; however, her stepmother took her and her sisters to church. ${ }^{678}$ After she began studying at Shaw University, the black Baptist church became the major community of her religious and social life. During the twentieth century, African American Baptist churches not only established their own denomination that was independent of the American Baptist denomination that white people dominated, but they also became actively involved in social activities for the civil rights of African Americans who were segregated by the American apartheid system. African American Baptists had fought against Jim Crow laws and had begun targeting the desegregation of public accommodations. ${ }^{679}$ They also worked with the NAACP to pass an anti-lynching bill during the early part of the twentieth century. ${ }^{680}$ African American Baptists did not stay in their church buildings for Sunday services but went out of their churches to protest against social injustice on the streets. The African American Baptist church had worked as a "race institution" that played an essential role in the advancement of black people. ${ }^{681}$ This tradition of the black Baptists, who had focused not only on church services but also on social justice, was exemplified by Cotton, who dedicated her life to protest for the rights of African

${ }^{678}$ Civil Rights History Project.

${ }^{679}$ Higginbotham, Righteous Discontent, 222.

680 Ibid., 224.

681 St. Clair Drake and Horace R. Cayton, Black Metropolis: A Study of Negro Life in a Northern City (Chicago: University of Chicago Press, 1993), 424. 
Americans in secular society and who tried to find the value and relevance of the social movement from her Christian faith inside her church community.

Cotton's religious life was balanced with activities inside and outside of church. As she had experience working as a housekeeper beginning in her teenage years, Cotton actively joined clubs that served church members and guests in the Gillfield Baptist Church, such as the Birth Month Club and the Young Women's Parish Club. ${ }^{62}$ These clubs helped church members connect with each other and host guests of the church. As a service of the Young Women's Parish Club, Cotton hosted King when he visited the church. When she worked for SCLC as one of its executive staff members, Cotton was frequently the only woman at SCLC's executive staff meetings during the mid to late 1960s. She had to prepare coffee and take notes for the meetings. ${ }^{683}$ However, Cotton was not submissive to the attitude of the male clerical leaders of SCLC. She never lost her identity as an equal among the male civil rights leaders of SCLC, and she had confidence herself: "I have the important role, and I am smarter than these men." 684

As she confessed in her interview, "we [SCLC leaders] were growing." Thus, Cotton did not condemn the male chauvinistic attitude of SCLC leaders as Baker did; her selfconfidence despite the unequal gender roles among SCLC leaders had been developed through her experience of housekeeping for the president of Shaw University. ${ }^{685}$ While she had worked for Dr. Robert Prentiss Daniel, who was an African American Baptist preacher and the president of the Baptist church-founded university, Cotton had experienced the unequal attitude of the black elites toward her as an African American woman, part-time student, and housekeeper. ${ }^{686}$ When she was not allowed to sit at Dr. Daniel's banquet table

682 Cotton, If Your Back's Not Bent, 74.

683 Civil Rights History Project.

684 Ibid.

685 Ibid.

686 Cotton, If Your Back's Not Bent, 52-55. 
for the school's faculty members, Cotton told herself, "Tomorrow, / I'll be at the table / When company comes," as Langston Hughes wrote in his poem "I, Too."687 Even though Cotton did not revolt against the male-centered attitudes of the black ministers, she kept her own equal gender identity and created independent social activities in the Gillfield Baptist Church and SCLC. As the WC women had not revolted against the male-dominated leadership in the NBC, but had kept their own independent activities, Cotton's religious life as a civil rights leader was like the WC women's experience.

In her interview, Cotton identified the civil rights movement as a movement of "spirit." 688 She interpreted the movement by saying that the "spiritual quality" of the civil rights leaders, such as Septima Clark, Esau Jenkins, and Martin Luther King, Jr., inspired other people to have the "spiritual aspect of life" that goes beyond a specific religious category. ${ }^{689}$ Cotton's interpretation of the civil rights movement as a movement of individual spirit enabled the participants in the movement to share independent leadership. Through developing the CEP's grassroots leadership, Cotton envisioned the civil rights movement of the CEP as "something other than march," which was defined as not just marching but the "whole operation" of the people's "spiritual aspect of life" for civil disobedience. ${ }^{690}$ Cotton encouraged grassroots people to have an individual "spiritual quality" through singing spirituals. The spirituals had the same lyrics as during the time of slavery, or the lyrics were changed for demonstrations. For instance, the spiritual lyrics, "The reason I sing this song, Lord, I don't want to be lost," were changed to, "The reason I pray so hard; the reason I go to jail; the reason I register and vote." 691 Following the interdenominational black church

687 Ibid., 54. Another version of Hughes's poem is "To-morrow, / I'll sit at the table"; see David Levering Lewis, ed., The Portable Harlem Renaissance Reader (New York: Penguin Books, 1994), 257-258.

688 Civil Rights History Project.

689 Ibid.

${ }^{690}$ Ibid.

691 Cotton, If Your Back's Not Bent, 151. 
tradition, which sang freedom songs to express people's suffering and hope for freedom, Cotton taught and encouraged the students of the CEP and the local people to express the spiritual aspect of their lives through singing freedom songs. ${ }^{692}$

Cotton's singing of freedom songs together with social activism continued in the CEP workshops, on the buses of the Freedom Rides, and during the mass protests in Birmingham, St. Augustine, and Selma. In these protests, Cotton and other civil rights activists sang freedom songs such as "I Been in the Storm So Long, Gimme a Little Time to Pray" when they experienced police brutality, and their singing of freedom songs was used as a powerful weapon to resist violence in a nonviolent way. ${ }^{693}$ Singing freedom songs also enabled grassroots people to be the subjects of the movement because the communal singing placed all of the movement's participants into the center of demonstrating their suffering and hope for freedom. Cotton witnesses in her autobiography that the freedom songs affirmed the grassroots leadership by redefining each person as a subject of freedom. She describes in her autobiography, "The music signaled a shift in consciousness and changed motivational paradigms, helping African Americans redefine and express our natural selves' way of thinking." 994 The freedom songs empowered the grassroots freedom fighters to share their communal sufferings and hope, and as Dorothy Cotton, Annell Ponder, and Fannie Lou Hamer experienced victory over the jailers' brutality at Winona jail, they could redefine themselves as the unbeatable victory-holders who demonstrated by singing "We Shall Overcome" and "This Little Light of Mine." 695

${ }^{692}$ Hans A. Baer and Merrill Singer, African American Religion: Varieties of Protest and Accommodation (Knoxville: The University of Tennessee Press, 2002), 254; and Cotton, 149. ${ }^{693}$ Ibid., 149.

694 Ibid., 153.

695 Civil Rights History Project. Concerning the tradition of black churches sharing a communal experience through singing spirituals, see Albert J. Raboteau, Slave Religion: The "Invisible Institution" in the Antebellum South (New York: Oxford University Press, 2004), 246. 
Cotton's belief in people's "spirit," which was the motivating power of the civil rights movement, opened her heart to other civil rights activists and organizations, even though they had different tactics and approaches for the movement. As she encouraged the civil rights activists to sing "I'm Gonna Do What the Spirit Says Do!"-whose lyrics were changed to "I'm gonna vote if the spirit says vote!"-Cotton and the CEP graduates went beyond the realm of SCLC by having the supreme goal of voting rights as God-given rights for all citizens. ${ }^{696}$ Cotton and the CEP graduates supported the Freedom Rides that CORE had initiated and that SNCC had participated in. ${ }^{697}$ Cotton contributed to activating the Birmingham Campaign by recruiting the CEP graduates in Birmingham. ${ }^{698}$ She also operated "training workshops" in Birmingham for teaching children and adults how to protest in nonviolent ways. ${ }^{699}$ Cotton and the civil rights activists mostly used church community people and church buildings to organize the protests in Birmingham. Throughout the March on Washington, the St. Augustine protests, and the Selma to Montgomery marches, Cotton was able to intensify the grassroots efforts in the local communities and to recruit grassroots leaders through sharing the spirit of craving for human dignity. Cotton was willing to welcome Malcolm X's visit to her SCLC office to share his idea of planning a new organization. ${ }^{700}$ Her spiritual focus within the civil rights movement enabled her to cooperate with white participants in the CEP, Fannie Lou Hamer and John Lewis of SNCC, and the people of the NAACP and CORE. ${ }^{701}$

696 Cotton, If Your Back's Not Bent, 134, 145.

697 Ibid., 208.

698 Ibid., 209-210.

699 Ibid., 213.

700 Ibid., 20-21.

701 Ibid., 118, 177, 242. 


\section{Fannie Lou Hamer}

Fannie Lou Hamer also drew on her black Baptist church tradition for demonstrating her faith in the civil rights movement. In 1917, Hamer was born into a Mississippi sharecroppers' family and grew up with nineteen older brothers and sisters. Her father was a Baptist preacher and her mother was also a sincere Baptist. ${ }^{702}$ When she was six years old, the Hamers' landowner forced her to pick cotton for food and clothing because her family was very poor. ${ }^{703}$ Around the age of twelve, Hamer wanted to be white because white people had enough food, a home to live in, and did not work as the black people worked all day. Hamer experienced the extreme poverty of black people during her childhood, and she realized that there was something wrong with the social structure in Mississippi. ${ }^{704}$ When her mother lost her sight in an accident working on their farm, Hamer made a decision to change "the power structure" of Mississippi; she did not want to pass on the sufferings of her and her mother to her children if she could avoid it. ${ }^{705}$ Hamer's self-enlightenment of the need for social changes began with her early years of poverty, and she always wanted to fight for the changes; however, she didn't know how to fight and organize people in the rural area of Mississippi. ${ }^{706}$ While she was attending the Williams Chapel Missionary Baptist Church, Hamer heard that there would be a mass meeting at the church led by SNCC people. ${ }^{707}$ At the meeting, Hamer finally found out how she could act to change the social structure of segregation and poverty.

\footnotetext{
702 Ross, Witnessing \& Testifying, 91.

703 “Oral history interview with Fannie Lou Hamer, Negro, woman, FDP: member of ex com.," 0491, Ruleville, Mississippi, https://exhibits.stanford.edu/projectsouth/catalog/zb317wv2717.

704 Ibid.

705 Ibid.

706 New York Public Radio Archives \& Preservation, "Interview with the Civil Rights Legend Fannie Lou Hamer in August of 1964," http://www.wnyc.org/story/interview-civilrights-legend-fannie-lou-hamer/.

707 Ibid.
} 
Hamer tried to register to vote right after the meeting, but she could not pass the literacy exam that she had never seen before. After her first attempt to register, Hamer's white landowner forced her to withdraw her attempt or leave her home. Hamer said to the landowner, "I didn't try to register for you, I was trying to register for myself."708 Hamer's rejection of her landowner's instruction demonstrates that her self-determination was in accordance with her black Baptist church background in the WC tradition. Having just eight years of schooling, Hamer realized deep within herself the wrongness of the system of her society that incarcerated African Americans through social segregation. In his Slave Religion: The "Invisible Institution" in the Antebellum South, Albert J. Raboteau analyzes the character of the black Baptist preachers in the antebellum South as being poor educated clergy but also talented exhorters who awakened unconverted minds. ${ }^{709}$ Like Raboteau's description of the traditional qualities of black Baptist preachers, Hamer was a self-enlightened exhorter against the unjust world, regardless of her poor education and living environment. Based on the black Baptist tradition of stressing individual enlightenment, Hamer was able to focus on her own enlightenment that justified her social disobedience toward unjust segregation. ${ }^{710}$

Before the Democratic Credentials Committee on August 22, 1964, Hamer's powerful witness of beatings in the Winona jail was broadcast nationwide: "I question America. Is this America? The land of the free and the home of the brave, where we have to sleep with our telephones off of the hooks because our lives be threatened daily, because we want to live as decent human beings, in America?"711 Her simple and fervid voice was strongly reminiscent of the classic image of the black Baptist as an exhorter and prophet toward a sinful society.

\footnotetext{
708 Ibid.

709 Raboteau, Slave Religion, 133-134.

710 Ibid., 132.

711 Fannie Lou Hamer, "Testimony before the Credentials Committee, DC Convention," August 22, 1964, American Rhetoric, http://www.americanrhetoric.com/speeches/fannielouhamercredentialscommittee.htm. 
Compared to King's fluent and philosophic sentences in his speeches, Hamer's simple language and cogent arguments were closer to the speaking style of traditional black Baptist preachers. In his "I Have a Dream" speech at the March on Washington for Jobs and Freedom on August 28, 1963, King stated, “This sweltering summer of the Negro's legitimate discontent will not pass until there is an invigorating autumn of freedom and equality ... Those who hope that the Negro needed to blow off steam and will now be content will have a rude awakening if the nation returns to business as usual. . . The whirlwinds of revolt will continue to shake the foundations of our nation until the bright day of justice emerges.",712 The flowery style of the language, such as "sweltering summer of the Negro's legitimate discontent" and "an invigorating autumn of freedom," in King's speech highlights his appearance as an elite leader to nationwide audiences. Conversely, Hamer's nationwide speech to the Democratic Credentials Committee was reminiscent of the traditional black Baptist prophet and opened the era of grassroots leadership in the civil rights movement.

Moreover, Hamer frequently revealed the sufferings of African Americans due to the brutality of white racists. She testified: "And you know, all that screamin and all of that will always follow me." "So then I had to get over there on the bed flat on my stomach and that man beat me ... that man beat me till he give out." "Over in the night I heard screamin . . I heard screamin." "That was a death place down there. I don't see how in the world . . I don't see how under the sun that a people could do human beins like they're doin them." "And after I got out of jail, half dead, to find out that Medgar Evers had been shot down in his own yard ... And they keep on sayin, 'Wait,' and we been waitin all of our lives and still gettin killed, still gettin hung, still gettin beat to death. Now we tired waitin!"713 Hamer's highlighting of

712 King, The Autobiography, 224-225.

713 Transcript of an interview with Fannie Lou Hamer, June 1963, http://www.crmvet.org/nars/63_flh_winona.pdf. 
suffering was in accordance with the origins of the black church and was connected to the black church's aspiration for freedom. James Cone concludes in Black Theology and Black Power that "the black church was the creation of a black people whose daily existence was an encounter with the overwhelming and brutalizing reality of white power."714 Thus, Hamer's witness disclosed the very essence of the black church's existence as one of resistance against injustice and a longing for liberation. Even though King also highlighted the sufferings of African Americans, his witness was closer to an interpretation of them than to an expression of the reality of that suffering. Hamer's testimony was the reality and direct delivery of being an eyewitness to the sufferings. Thus, even though King appeared as the spokesman of the civil rights movement, Hamer had the image of the freedom fighter who "made up the central theme of the black church; and protest and action were the early marks of its uniqueness, as the black man fought for freedom," according to Cone. ${ }^{715}$

Hamer also witnessed the hypocrisy of the white church, which ignored the sufferings of its black Christian neighbors. After Hamer was severely beaten in the Winona jail, Hamer and Ponder asked for cold water when some people passed their jail cell. These people were the jailer's wife and daughter, and they brought some cold water to them. Thankful, Hamer told them, "You all are nice. You must be Christian people."716 The jailer's wife told Hamer that she "tried to live a Christian life." 717 Then Hamer challenged them to read Proverbs 26:26 ("His malice may be concealed by deception, but his wickedness will be exposed in the assembly") and Acts 17:26 ("From one man he made every nation of men, that they should inhabit the whole earth; and he determined the times set for them and the exact places where

\footnotetext{
714 James H. Cone, Black Theology and Black Power (Maryknoll: Orbis Books, 2001), 92.

715 Ibid., 94.

716 Transcript of an interview with Fannie Lou Hamer, June 1963, http://www.crmvet.org/nars/63_flh_winona.pdf.
}

717 Ibid. 
they should live"). ${ }^{718}$ The jailer's wife wrote down those verses; however, she never came back. Hamer thought that the jailer's wife could not understand the meanings of those verses, which taught the sinful violence of her husband and the racist society. ${ }^{719}$ Hamer's witness of white Christians' ignoring black people's equality, which the Bible clearly supports, corresponds to the uniqueness of black theology as being about liberation, as Cone insists in his article, "Black Theology as Liberation Theology." In this article, Cone points out the difference between the white church and the black church: "Because white theologians and preachers denied any relationship between the Scriptures and our struggle for freedom, we [black theologians and freedom fighters] bypassed the classic Western theological tradition and went directly to Scripture for its word regarding our Black struggle."720 Just as Cone finds the uniqueness of black Christians' struggle for liberation in differentiation from the Western Christian tradition, Hamer's finding of her identity through her experience of suffering for freedom was empowered more by the black church than by King's pursuit of racial integration through Christian love.

\section{The African Methodist Episcopal Church Women's Tradition}

\section{Rosa Parks}

Rosa Parks attended the HFS's Citizenship School in the summer of 1955. She spent ten days there attending workshops, and she met with Septima Clark. Parks's experience of the HFS's workshops provided her with a very special experience of racial integration and grassroots leadership. When she visited the HFS, Parks was forty-two years old; she refused to yield her seat on a segregated bus to a white person a few months later. While she was visiting the HFS, Parks attended the Citizenship School workshop and the Racial

\footnotetext{
718 Ibid.

719 Ibid.

720 James H. Cone, "Black Theology as Liberation Theology," in Down by the Riverside: Readings in African American Religion, ed. Larry G. Murphy (New York: New York University Press, 2000), 396.
} 
Desegregation: Implementing the Supreme Court Decision workshop. ${ }^{721}$ Parks experienced racial equality and the power of racial integration from these workshops. The HFS was an integrated school, and Parks was able to meet white colleagues. Parks could eat, dance, and share her life with black and white participants of the HFS without any racial prejudice toward one another. ${ }^{722}$ When she had to leave Highlander, Parks felt uncomfortable because she had to go back to the segregated society of Montgomery, and she felt more miserable than ever before. ${ }^{723}$ The integrated workshops of the HFS highlighted the segregation of Montgomery, where Parks had to live with racial inequality. ${ }^{724}$

Parks's uncompromising resistance against segregation laws was based on her education and was how she desegregated the society of the Jim Crow laws. First, Parks had learned the equal rights of African Americans from reading the Bible and from the teachings of her family. She confessed, "From my upbringing and the Bible, I learned people should stand up for their rights, just as the children of Israel stood up to Pharaoh."725 Her mother, Leona McCauley, taught her self-respect and human dignity based on biblical teachings. McCauley led Parks to read the Bible when she needed guidance and courage. ${ }^{726}$ Parks's maternal grandmother, Grandma Rose, was a role model for Parks to be a strong-willed woman, and she taught her "to be a strong woman" through her Christian faith. ${ }^{727}$ Parks learned to keep her racial identity and her self-awareness of humanity's equality through her Christian family, especially from her maternal grandfather, Sylvester Edwards, who resisted the racism of his white neighbors. ${ }^{728}$ He taught Parks about real courage through his defense

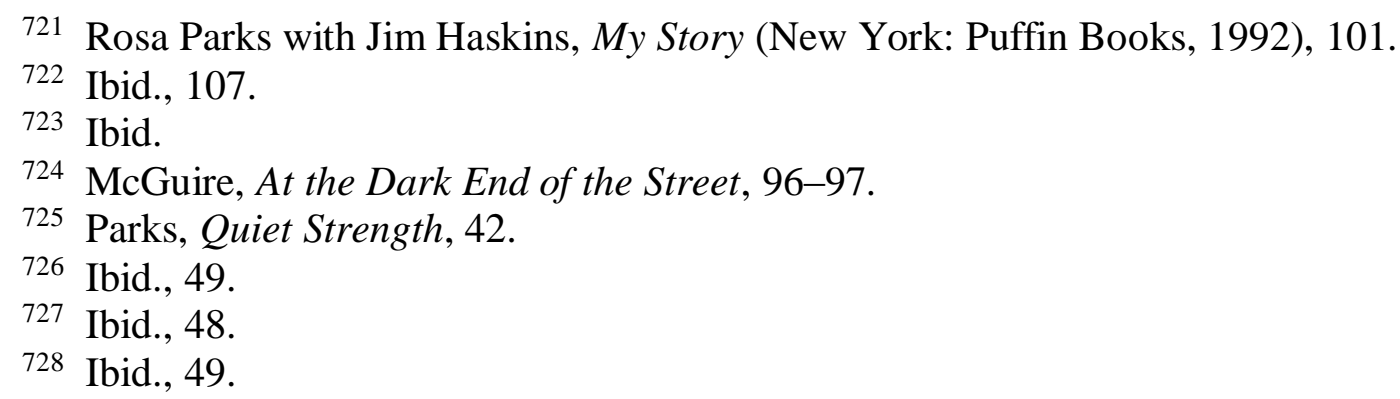


of his family against the threats of the Ku Klux Klan people in Pine Level, Montgomery. ${ }^{729}$ Based on her memory of her maternal grandfather, Parks "learned not to let anyone mistreat us." 730

Parks attended a private junior high school, the Montgomery Industrial School, which was founded and operated by Alice L. White, because as a licensed school teacher, Parks's mother wanted to send her daughter to this distinguished school. ${ }^{731}$ All the students of this school were African American girls, and all the teachers were white. Principal White was a Caucasian woman who had come from Massachusetts, and she practiced racial integration in her institution. ${ }^{732}$ From Principal White and the other teachers of this school, Parks learned the equal dignity of African Americans and self-respect, which enabled her to escape the brainwashing of racial inferiority. ${ }^{733}$ Through these educational experiences of racial integration at the HFS and the Montgomery Industrial School, Parks experienced the social irony between racial segregation and racial integration that existed together in her community. Parks also testified that she had lived with this irony from childhood. When she was about five or six years old, Parks lived with her maternal grandparents, who worked for a plantation owner named Moses Hudson. ${ }^{734}$ During that time, Parks met a white soldier who was Hudson's son-in-law and who came from the North. The soldier treated Parks without any racial discrimination. ${ }^{735}$ Parks had wondered why other whites did not treat African American children with the same attitude they had toward white children, like this white soldier did. Parks's resistance against segregated busing was based on her life experiences and education.

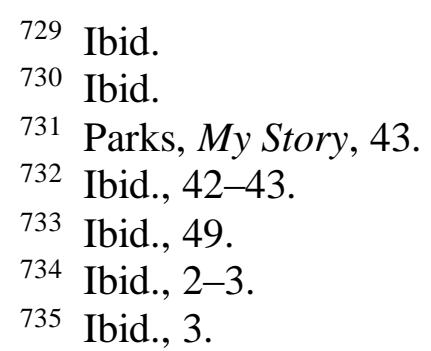


Parks needed to be courageous to react against segregated society. Even though she had been surrounded by the violent racism of white people from childhood, her Christian family background and her faith gave her inspiration to be courageous and to resist racial segregation. ${ }^{736}$ Parks attended the Mount Zion African Methodist Episcopal Church, whose pastor was her mother's brother. In her autobiography, Parks testifies that Psalms 23 and 27 always gave her comfort and courage. ${ }^{737}$ Parks had learned over the years how to make up her mind through her faith, and she witnessed, "I felt the Lord would give me the strength to endure whatever I had to face."738 In her autobiography, Ready from Within, Septima Clark describes Parks's fear of going back to the segregated town of Montgomery. ${ }^{739}$ However, in her autobiographies, Parks does not witness about her fear; she just states that she was hesitant to go back to Montgomery after being in the peaceful integrated community of the HFS and that she was never afraid to resist surrendering her seat on a segregated bus. ${ }^{740}$ Jo Ann Robinson of the WPA, who worked with Parks during the Montgomery Bus Boycott, also described Parks as unassuming and strong. ${ }^{741}$ Thus, as Parks witnesses in her autobiography, she was strong enough to resist the bus driver's enforcement of segregation policy, and she was also not old nor physically tired when she refused to surrender her seat. ${ }^{742}$ Parks was courageous enough to fight against racism based on her Christian faith. As she witnessed, "Getting arrested was one of the worst days in my life. It was not a happy experience. Since I have always been a strong believer in God, I knew that He was with me, and only He could get me through the next step." "743

\footnotetext{
736 Parks, Quiet Strength, 16.

737 Ibid., 55-58.

738 Ibid., 17.

739 Clark, Ready from Within, 33.

740 Parks, My Story, 106-107, 116-118.

741 Robinson, The Montgomery Bus Boycott and the Women Who Started It, 43.

742 Parks, My Story, 116.

${ }^{743}$ Parks, Quiet Strength, 23.
} 
Parks began to work for the NAACP with her husband, Raymond Parks, when the organization helped to appeal the case of the Scottsboro Boys, in which nine black teenaged boys were falsely accused of raping two white women on a train in the 1930s. Policemen were frequently suspicious of the supporters of the boys, and Parks and her husband could have been targeted by white racists. However, they did not quit helping the Scottsboro Boys, taking the risk of being shot by white racists. ${ }^{744}$ Parks also helped local people register to vote, along with E. D. Nixon, who was the leader of the NAACP and of the Brotherhood of Sleeping Car Porters during the 1940s. ${ }^{745}$ Parks participated in the workshops of the HFS as a guest speaker with King during and after the Montgomery Bus Boycott. Parks also joined the March on Washington and the Selma to Montgomery marches. In 1987, Parks established the Rosa and Raymond Parks Institute for Self-Development, which she envisioned as a community center for educating young people. ${ }^{746}$ This institute demonstrates her enthusiasm for educating and cultivating the local leadership of young people. When Parks refused to surrender her seat on a segregated bus, she was on her way to prepare a NAACP workshop for young people. ${ }^{747}$ Parks's life of resistance against social injustice focused on her dedication to educating for self-development and for resisting for independent rights. Her independent and resistant spirit was similar to the tradition of the AME Church and its women.

Parks demonstrated that her fight for freedom was based on the tradition of the AME Church: 'People often ask me, 'Why was the church a part of the movement?' It was the only legal place our people could gather and get information without being harassed or unjustly treated."748 She witnessed that the black church was "the foundation of our community" that

\footnotetext{
744 Parks, My Story, 64.

745 Ibid., 73.

746 Ibid., 181-182.

747 Ibid., 113.

748 Parks, Quiet Strength, 30-31.
} 
provided strength and refuge. ${ }^{749}$ Parks recognized the AME Church as "the Freedom Church" that had fought for the freedom of slaves during the abolitionist movement. ${ }^{750}$ She had learned from the freedom fighters of the AME Church, who were "Bishop Richard Allen, Frederick Douglass, Harriet Tubman, and Sojourner Truth." ${ }^{, 751}$ From these AME people, Parks learned how to use "Scriptures, testimonies, and hymns" to resist racial hatred and violence. ${ }^{752}$ Moreover, Parks initiated "the Pathway to Freedom" program at her Rosa and Raymond Parks Institute for Self-Development, which taught young people how these freedom fighters brought their black church tradition of fighting for freedom into the civil rights movement. ${ }^{753}$ Thus, the AME Church's tradition of fighting for freedom was internalized into Parks's civil rights movement. Compared with Baker and Cotton, who used the organizational social justice activities of the black Baptist Church to help with the civil rights movement, Parks tried to practice the spiritual tradition of the AME Church for fighting for freedom in her personal resistance against social segregation. Even though the AME Church also had developed its organization's social justice activities, AME Church people can be highlighted for their development of individual resistance for freedom and independent souls, as Parks had done.

\section{The AME Church}

Parks testified that her historical understanding of Bishop Richard Allen's freedom movement influenced her fight for freedom. The first AME church began with the separatist movement of African American Methodists, whom Richard Allen led in 1787 when they left St. George's Methodist Episcopal Church, which had oppressed its black congregation. ${ }^{754}$

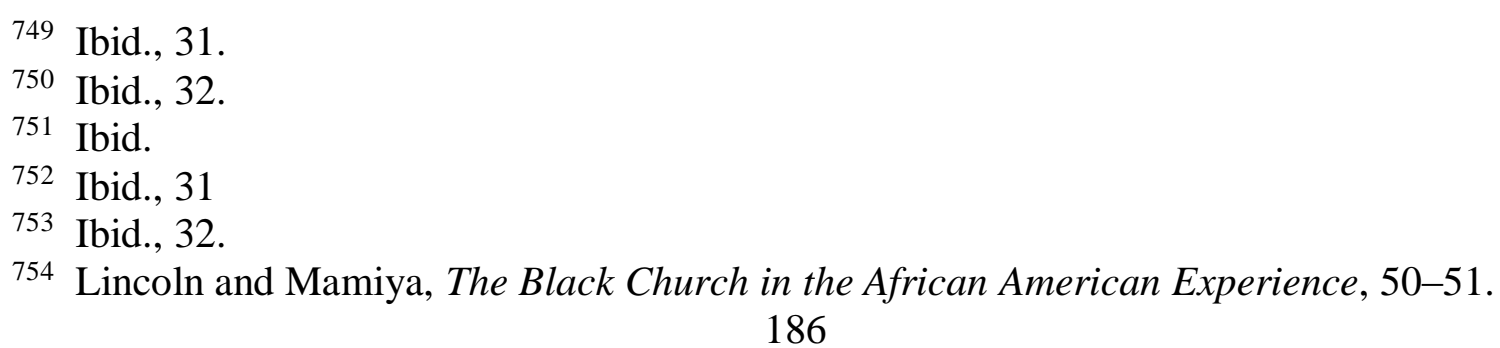


Allen and the separatists organized the Free African Society, and Allen and some of the separatists founded the AME denomination in 1816 through the help and ordination of Francis Asbury, who was the first bishop of the Methodist Episcopal Church in the United States and one of the leaders of the Second Great Awakening. For about thirty years after their separation from St. George's Methodist Episcopal Church, Allen and his congregation fought to have their independent congregation ratified by the Methodist Episcopal Church, without success. Other separatists of the Free African Society founded various denominations and churches in northern cities, and they and the AME churches helped and cared for the people who escaped from the South through the Underground Railroad. ${ }^{755}$ From these experiences during the initial stage of their denomination, the AME churches established a tradition that focused on providing support services of housing and education for needy people. $^{756}$

As Allen was fighting to establish an independent black church denomination in keeping with the doctrine of the Methodist church, Jarena Lee, a woman who was called to be an itinerant exhorter of the AME Church, began asking Allen for permission to preach (around 1811). ${ }^{757}$ Allen allowed Lee to preach at the public meetings of the AME Church in 1819. Lee traveled to many cities in the Northern and Middle states until the 1850s and delivered about seven hundred sermons. ${ }^{758}$ Throughout her career as an exhorter, Lee fought for the formal authority of AME women to preach. ${ }^{759}$ Lee also published a thousand copies of her testimony and autobiographical memoir, The Life and Religious Experience of Jarena Lee. In this book, Lee insist on the equal right of women to preach the gospel: "For as

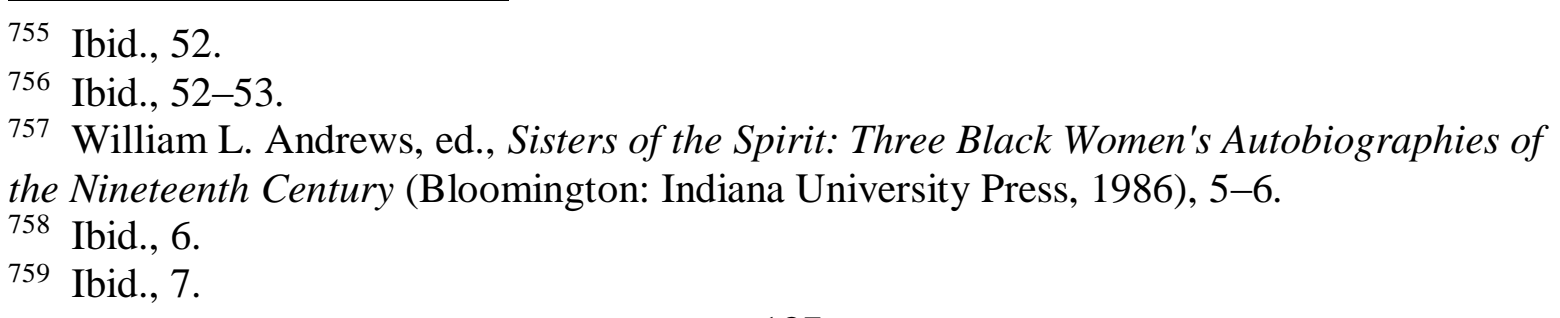


unseemly as it may appear nowadays for a woman to preach, it should be remembered that nothing is impossible with God. And why should it be thought impossible, heterodox, or improper, for a woman to preach? Seeing the Saviour died for the woman as well as the man." ${ }^{, 760}$ In 1840, Lee confirmed that the gospel supports abolitionism and participated in the American Antislavery Society. ${ }^{761}$ Lee's self-awareness of racial and gender rights was founded in the denominational tradition of the AME Church. Along with Allen's fighting for an independent church denomination for African Americans, the struggles of Lee for women's rights and abolition accorded with the courage of Rosa Parks, who stood up for racial rights as an independent Christian woman in the AME Church tradition. Parks confessed, "My strength has always come from the church. I have always gained strength from thinking about the Bible and from the faith of my family."762

The women of the AME Church also had developed the individual freedom fighters' tradition as educators for self-awareness and self-help. This tradition had continued with the educators for voting rights, such as Septima Clark. AME Church women had been fighting for full equality in ordination as ministers, when, in 1948, they attained ordination rights as local deaconesses. They finally attained full rights to be women ministers in $1960 .{ }^{763}$ This was the result of the long struggles of AME Church women for equal rights to minister. Earlier than other African American denominations, the AME Church licensed women preachers such as Jarena Lee, Sophie Murray, Harriet Baker, and Sarah Ann Hughes, women who had continually asked for the right to preach from the antebellum era to the early twentieth century. ${ }^{764}$ AME women expanded the women's rights movement in the church to

\footnotetext{
760 Jarena Lee, "The Life and Religious Experience of Jarena Lee," in Riggs, ed., Can I Get a Witness? 7.

761 Andrews, ed., Sisters of the Spirit, 6.

762 Parks, Quiet Strength, 70.

763 Collier-Thomas, Jesus, Jobs, and Justice, 90.

764 Ibid., 89.
} 
the equal rights movement for women and black people in American society. Women of the AME Church also had contributed to the development of the education of young African Americans and charity movements in their communities. From the 1880s, AME Church women had tried to establish local independent clubs for African American women to help the illiterate and the local poor. ${ }^{765}$ AME women who graduated from Wilberforce University, which was founded by the AME Church and the Methodist Episcopal Church in 1856, became the first itinerant teachers who left their hometowns to teach uneducated Southern black people. ${ }^{766}$ In the middle of the 1860 s, AME women educators who graduated from Wilberforce, such as Hallie Quinn Brown and Jane Lynch, began teaching reading, writing, voting, and banking to adults and children in Mississippi and South Carolina. ${ }^{767}$ In 1901 , they established the Deaconess Home and Girls' Training School in Virginia, which educated young black people to prepare them for skilled jobs and citizenship. ${ }^{768}$

AME women were pioneers of nationwide African American organizations for educating people to advance their civil rights. Mary Church Terrell, who was appointed as the first African American woman member of the District of Columbia State Board of Education, cofounded the NAACP and the National Association of Colored Women. Terrell dedicated her life to empowering the self-respect of black women. She developed women's clubs that expanded church women's clubs to secular areas. ${ }^{769}$ Terrell participated in the Colored Women's League and in the women's suffrage movement through the National American Woman Suffrage Association. In the District of Columbia, Terrell fought against a segregated restaurant that refused to serve her and her colleagues in 1949. While her lawsuit case was

\footnotetext{
765 Ibid., 264.

766 Jualynne E. Dodson, Engendering Church: Women, Power, and the AME Church (Lanham: Rowman \& Littlefield Publishers, INC., 2002), 72.

767 Ibid.

768 Collier-Thomas, Jesus, Jobs, and Justice, 91.

769 Mary Eliza Church Terrell, A Colored Woman in a White World (Washington, DC: Ransdell Inc. Printers and Publishers, 1940), 149.
} 
pending, Terrell did sit-ins, boycotts, and picketing to fight against segregation. ${ }^{770}$ In 1953 , the Supreme Court declared that the segregated restaurants were unconstitutional. In her autobiography, Terrell describes her life fighting for justice, “A white woman has only one handicap to overcome - that of sex. I have two - both sex and race. I belong to the only group in this country which has two such huge obstacles to surmount. Colored men have only onethat of race." 771

Ida B. Wells-Barnett, who was known as Ida B. Wells, led an anti-lynching campaign as a journalist, teacher, and activist. In 1884, Wells refused to surrender her seat in the ladies' section and move to the smoking section of a segregated train. She was forcibly banished from the train. Wells sued the railroad company in the Tennessee State Supreme Court. Even though she did not win the case, as a young woman in her twenties, Wells's resistance against the Jim Crow laws was known to people in the South. ${ }^{772}$ Wells was a co-founder of the NAACP, the Republican Women's Club, and the National Association of Colored Women. ${ }^{773}$ She also organized the Alpha Suffrage Club for women's voting rights. ${ }^{774}$ Wells spent her life redefining the womanhood of African American women. She recognized that "among the many things that have transpired to dishearten the Negroes in their effort to attain a level in the status of civilized races, has been the wholesale contemptuous defamation of their women."775 Wells interpreted women as the determiners of this world's fate because Eve tempted Adam to sin, and Mary gave birth to Jesus. Thus, Wells insisted on teaching people how to celebrate Christmas day: "Teach them this better way of honoring Him who made

770 Olson, Freedom's Daughters, 78-79.

771 Terrell, A Colored Woman, vii.

772 Ida B. Wells, The Memphis Diary of Ida B. Wells, ed. Miriam DeCosta-Willis (Boston: Beacon Press, 1995), xiv.

${ }_{773}$ Ida B. Wells, The Light of Truth: Writings of an Anti-Lynching Crusader, ed. Henry Louis Gates, Jr. (New York: Penguin Books, 2014), xxvii.

774 Dennis Brindell Fradin and Judith Bloom Fradin, Ida B. Wells: Mother of the Civil Right Movement (New York: Clarion Books, 2000), ix.

775 Wells, The Memphis Diary, 185. 
visible to the world that 'by woman came sin and death into the world — by woman, also, came redemption.",776 Her legacy of campaigning against lynching and for women's voting rights, resisting Jim Crow laws, and investigating the nature womanhood provided the footstool of the civil rights movement. Wells has been called the "mother of the civil rights movement." $" 777$

As AME women, Lee, Terrell, and Wells expanded their religious realization of women's rights in the church to pursue gender and racial rights in the society, and Septima Clark tried to practice women's rights in her religious organization (SCLC) and to extend these rights to local areas and to the civil rights movement in American society. Dedicating her life to educate local black people, Clark followed in the AME women's tradition of women educators who had developed the rights of race, gender, and voting, just as they had realized the need for these rights in their religious life. These AME women specialized their educating experiences in promoting the social rights of black people who were in povertystricken areas of the South. Compared with the clerical leaders of SCLC, who had focused on mass movements and Southern-wide Christian organizations, the AME civil rights women, as laywomen educators, concentrated on their independent fights for freedom and on participating with interreligious social organizations; they tried to promote self-help and the self-awareness of local black people through educating them about the value of their human rights as God's children, which Jesus supported in the Bible.

\section{Septima Clark}

As with Terrell and Wells, AME women's social work as career women and educators for the rights of women and voting and racial equality juxtaposed with the civil rights work of Septima Clark. Clark attended the AME church after her marriage and participated in

776 Ibid., 182.
777 Dennis Brindell Fradin and Judith Bloom Fradin, Ida B. Wells, xii. 
women's associations such as the Young Women's Christian Association (YWCA), the United Council of Church Women, the Women's International League for Peace and Freedom, and the Women's Federation. ${ }^{778}$ As the AME women struggled for equal rights for women and for poor local African Americans, Clark found out that there were problems with gender and class among the African American churches and social organizations. ${ }^{779}$

Sometimes she could not recommend that her citizenship school students attend Martin King Luther King, Jr.'s and Andrew Young's churches because the parishioners of their black Baptist and Congregational congregations would dress up for Sunday services, and Clark did not want her students to worry about what they wore to church. ${ }^{780}$ Clark had attended the Old Bethel United Methodist Church in her childhood; however, she moved to the AME church, following her husband, because she realized that the AME church was tolerant toward poor black people and treated people equally, even if they were single women or handicapped persons. ${ }^{781}$

Clark wanted to be a teacher from the time she was a youth. This interest began when she took her neighbor children to church; she liked it when they called her "Little Ma."782 Clark led a youth group at her church and taught children in Sunday school and Vacation Bible School. ${ }^{783}$ Clark's long-time interest in teaching children and her dream of buying a house for her mother led her to make the decision to be a teacher. ${ }^{784}$ After she graduated from high school in 1916, Clark began teaching children on Johns Island as a public school teacher of the Promise Land School, because black teachers were restricted from teaching at

778 Clark, Echo in My Soul, 95, 112; and SCLC, "Septima Poinsette Clark," 1964, KPKC, 124:5.

779 "Interviews with Septima Clark" by Taylor Branch, TBWL, 83:581.

780 Ibid.

781 Ibid.

782 Ibid.

783 Ibid.

${ }^{784}$ Clark, Ready from Within, 100. 
the public school in Charleston. Until 1945, there was no bridge connecting the island with Charleston. It took about nine hours to get to the mainland from the island by boat. Clark experienced the poverty and "virtual" slavery that led African Americans to work in the field without any hygiene or health care. ${ }^{785}$ In these circumstances of poverty, Clark saw many babies die due to poor care because their mothers had to go to work in the fields two or three days after delivering them. ${ }^{786}$ In the Promise Land School, there were about 130 students, most of whom could not attend school during the harvesting season because they had to work in the fields. Clark experienced that black people on Johns Island had a lack of public services, such as water, transportation, education, and health care, because they were secondclass citizens. ${ }^{787}$

As AME women had moved to educate Southern black students in poor rural areas, Clark initiated her teaching career on Johns Island. She realized that the poor local black people needed to gain equal rights through the exercise of political power. Having experienced the extreme levels of poverty and illiteracy on Johns Island, Clark focused on developing public and adult schools and political actions for black people in local areas. Clark helped found the NAACP chapter on Johns Island along with some preachers. ${ }^{788}$ Clark's first social activity with the NAACP was to help a black boy who delivered ice and was falsely accused and jailed for stealing his white woman customer's watch. The members of the NAACP's Johns Island chapter revealed that the woman's watch had been found in the laundry and got her public statement that the black boy was innocent. ${ }^{789}$ The next activity of Clark with the NAACP was to desegregate the hiring of black teachers for the public schools

\footnotetext{
785 “Interview with Septima Clark.” by Branch.

786 Ibid.

787 Ibid; and Steve Estes, Charleston in Black and White: Race and Power in the South after the Civil Rights Movement (Chapel Hill: University of North Carolina Press, 2015), 17.

788 "Interview with Septima Clark" by Branch.

789 Ibid.
} 
in Charleston, South Carolina. Clark and other NAACP members had a discussion with Tom Miller, who was the president of the South Carolina State College, about challenging the legislators of Charleston. ${ }^{790}$ He recommended that they get people's signatures on a petition requesting the hiring of black teachers for the public schools. Even though it damaged her teaching career in the public schools, Clark took her students to ask the Charleston residents to sign the petition, visiting people door-to-door. ${ }^{791}$ In 1920, the NAACP members and Clark finally got twenty-two thousand signatures, and the city of Charleston allowed the public schools to hire black teachers. ${ }^{792}$

Clark's social activities with the NAACP resembled Parks's activities as a NAACP agent. About forty years later, Clark visited the grassroots people door-to-door to encourage them to register to vote. As the AME women did in their social activities, Clark developed her field experiences into creating tactics for achieving civil rights for local black people. On Johns Island, Clark's field experience teaching poor, illiterate children and adults, who spoke Gullah (a mixture of African languages with English, French, and German developed during the slavery era), enabled her to maintain the Citizenship School until 1970. During its initial years, there was a challenge among the Citizenship School teachers because many of them were unwilling to teach the local people, whom they saw as too poor and illiterate to be educated. ${ }^{793}$ Clark's field experience also led her to develop practical tactics for achieving victory by desegregating the Jim Crow laws. CEP leaders such as Cotton and Young fully understood that the practical tactics of Clark were based on her lifelong field experience, and they could trust each other in their work at the CEP through respecting Clark's dignified experience. ${ }^{794}$ In 1937, at Atlanta University, Clark was the student of W. E. B. DuBois, who

\footnotetext{
790 Ibid.

791 Ibid.

792 Clark, Ready from Within, 110.

793 "Interview with Septima Clark" by Branch.

794 Ibid.
} 
cofounded the NAACP with AME women leaders; thus, Clark and Parks were familiar with working with the NAACP because of their AME church backgrounds. ${ }^{795}$ While the black Baptist women focused on promoting Baptist groups for social justice activities, the AME women's focus on developing individual fights for freedom led them to freely participate in inter- and non-religious nationwide organizations' social activities, such as those of the NAACP.

Clark's father and mother influenced the development of her character and selfawareness of her racial identity through their Christian faith. Clark's father, Peter Porcher Poinsette, was born as a slave on the Joel Poinsette Plantation. ${ }^{796}$ His slave owner, Joel Poinsette, treated Clark's father in gentle ways, and Clark's father never complained about his owner. During the Civil War, Clark's father helped Confederate soldiers and did not welcome his freedom from slavery because he was worried that he would not be able to get enough to eat. ${ }^{797}$ Clark's father experienced that he could get freedom from slavery through nonviolent means. He could accept his circumstances because his white slaveholders had been paternalistic toward him. Thus, Clark's father believed that patience was the best way to make a situation better. ${ }^{798}$ Clark learned the nonviolent life from her father. ${ }^{799}$ He had been illiterate until he was old; however, he had an enthusiasm to educate his children. Clark's father was not active in church, but he taught Clark to be a person who could help others in their weaknesses without haughtiness, bringing others to see "the spirit of Christ" in her life and to see others as Christ sees them. ${ }^{800}$ Clark's father met Clark's mother, Victoria Warren Anderson, while he was working on a ship. Clark's mother was born in Charleston but moved

\footnotetext{
795 Clark, Ready from Within, 116.

796 Ibid., 87.

797 Ibid., 88

798 Ibid.

799 "Interview with Septima Clark," by Branch. She was also a nonviolent fighter for freedom. See "Interview with Dorothy Cotton," by Wook Jong Lee.

${ }^{800}$ Clark, Ready from Within, 88, 97-98.
} 
to Haiti and grew up there. She never experienced slavery and moved to Florida when she was eighteen years old. Clark's mother was so proud that she was not brainwashed by American racial prejudice. She was very resistant to racism. Clark learned from her mother how a black woman could live courageously in a segregated society. ${ }^{801}$ Clark's mother also had an enthusiasm to educate her children, and Clark was able to attend a private high school, Avery Normal Institute, which trained black teachers. Clark's mother was an active church member, and Clark's Christian faith was influenced by her mother and her mother's church, the Old Bethel United Methodist Church.

Clark's belief in nonviolence led her to support King's nonviolent tactics, and her courageous resistance against unjust social systems, such as racism and male chauvinism, also enabled her to criticize the male leadership of King and SCLC. As Clark's father had taught her, Clark could teach the local poor with respect in the same way that Jesus saw their value. Emulating Jesus's life, and like the educated AME women who came down to the South to educate local black people in Mississippi, Clark tried to educate and lived together with the local poor on Johns Island. Based on her Christian faith in the equality of all humanity, Clark's experience of teaching the black people on Johns Island heavily impacted Andrew Young, Dorothy Cotton, Martin Luther King, Jr., and the tactics of SCLC. Even though Myles Horton was a strong egalitarian and founded the democratic tactics of the HFS, Horton had difficulty listening to poor and uneducated black people because he had to be patient with their stories that seemed void of meaning to him. ${ }^{802}$ When Clark initiated the CEP, the CEP teachers and Young also had difficulties working with the local poor people. Clark's well-trained Christian practice of educating poor black people with respect, which fell in line with the AME women's tradition, changed Young's middle-class mind so he could

801 Ibid., 96.

802 "Interview with Septima Poinsette Clark" by Eugene Walker, July 30, 1976, Atlanta, Georgia, HFS Archives. 
work "with low-income, poverty-stricken people." ${ }^{803}$ Moreover, Clark considered that Young "had the greatest influence on King" among SCLC staff leaders, and SCLC had "the greatest growth under Young."

Young's contribution to the growth of SCLC as the executive director played an essential role in transforming the mass-centered tactics of SCLC to the community-centered tactics of a grassroots movement. ${ }^{805}$ Young discovered the importance of organizing communities because there were many boycotts and sit-ins that were not as successful as those of Montgomery and Atlanta. This happened if they had no strategy to engage their own communities. ${ }^{806}$ As he learned from Clark at the CEP, Young helped King create a community strategy when SCLC initiated social programs in the communities of Birmingham, Selma, St. Augustine, Chicago, and Memphis. ${ }^{807}$ Moreover, Young influenced King's radical programs to address the economic struggles of African American communities after the Selma to Montgomery marches. ${ }^{808}$ Since Clark's Christian practices for training local black people with respect were the main factors of the civil rights movement, Young, King, and SCLC were heavily impacted by the grassroots tactics of Clark, which led to their focus on black communities' poverty in the later programs of SCLC. ${ }^{809}$

Clark's continued work with SCLC was dependent on her being able to share the Christian practice of nonviolent tactics with the organization. Clark respected King because she was an eyewitness to how he maintained nonviolent tactics even when he was in a situation where he might be killed by white mobs. ${ }^{810}$ Clark pointed out that SCLC

\footnotetext{
${ }^{803}$ Ibid.

804 Ibid.

805 Young, An Easy Burden, 282-283.

806 Ibid., 184. Scholarly Resources Inc., 2003), 22-36.

808 Dyson, I May Not Get There with You, 91.

809 Young, An Easy Burden, 154-157.

810 "Interview with Septima Poinsette Clark" by Walker.
}

807 Andrew J. DeRoche, Andrew Young: Civil Rights Ambassador (Wilmington, DE: 
"emphasizes the philosophy of non-violence in protesting iniquities and unfair treatment of the underprivileged." 811 She thought that SCLC's "two principal focal points" were nonviolence and voting rights. ${ }^{812}$ Based on these points of SCLC, Clark believed that SCLC's philosophy was Christian and matched Gandhi's philosophy of "true force." ${ }^{\prime 13}$ Clark insisted that the nonviolent tactics of SCLC worked like "true force," which enabled SCLC to attain victory because the force did not retaliate against enemies but converted them into friends. ${ }^{814}$ She also persuaded Stokely Carmichael, who was the chair of SNCC and a leader of violent resistance, to leave the Black Power movement because violent resistance could not win; years later, he actually quit the Black Power movement after traveling to Africa. When Carmichael decided to leave the Black Power movement, he remembered, "Mrs. Clark talked with me." 815 Clark's belief in nonviolent resistance was her way of overcoming fear of the violence of racists. She faced a lot of violent attacks during her voting rights movement in Alabama and Mississippi. ${ }^{816}$ In Greenwood, Mississippi, Andrew Goodman, Michael Schwerner, and James Chaney, who worked for the voting rights movement of CORE, were killed in 1964. They were working for the Freedom Summer, which Clark's Citizenship School had influenced. ${ }^{817}$ When Clark finished a voting rights workshop at a Baptist church in Granada, Mississippi, and walked out, the church was completely burned, except for its corners. ${ }^{818}$ Working for voting rights meant fighting for those rights at the risk of death during the 1960s. As her mother had taught her, Clark maintained her courage in the face of death by drawing on her Christian faith in nonviolent resistance. ${ }^{819}$

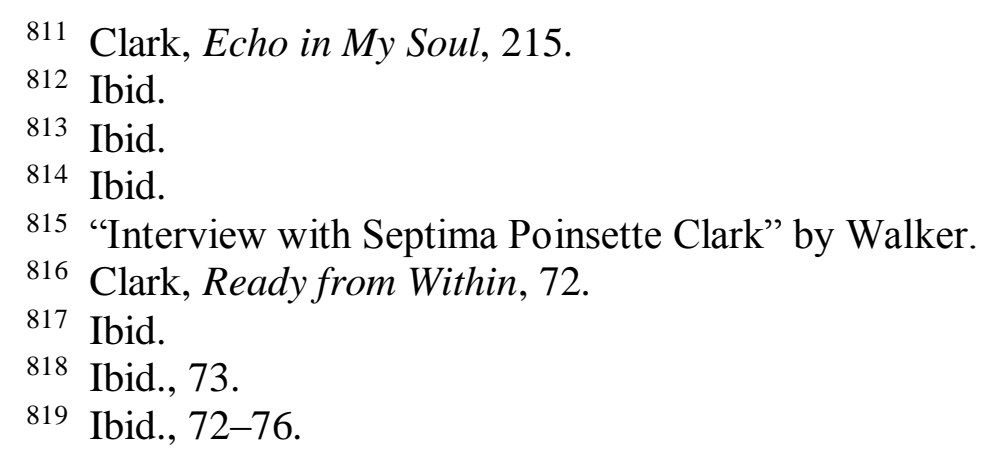


Clark also had struggled with women's rights to speak and to lead social organizations, as the AME women had. Like Mary Church Terrell, Clark delved into African American women's twofold struggle: "For black women, the problem was two-fold: being a woman and being black." ${ }^{820}$ As the AME women specialized in expanding their movement for women's rights in the church to the gender rights movement in society, Clark developed her assertion of women's rights from SCLC to the American society. Clark fully realized that the women's liberation movement had begun prior to the start of the civil rights movement: "This country was built up from women keeping their mouths shut. It took fifty years for women, black and white, to learn to speak up. I had to learn myself, so I know what a struggle it was." ${ }^{821}$ To prove the early burst of the women's liberation movement, Clark mentioned that she had been invited by Virginia Durr, who was a white woman activist and supporter of Rosa Parks, to speak for black church women in Montgomery in 1955, before the bus boycott broke out. ${ }^{822}$ While she was writing her autobiography Ready from Within, Clark noted that she was proud to be included as one of the black women who shaped America, along with Ida B. Wells, in the 1974 book Black Women of Valor by Olive Burt. ${ }^{823}$ This recognition proves that Clark tried to continue the AME women's tradition as a social activist, educator, and leader of the women's movement through women's organizations.

As was mentioned in Chapter two, Clark criticized King's ignorance in not inviting her to speak during the meetings when he received the Nobel Peace Prize, along with the male chauvinism of SCLC male clerical leaders, such as Ralph Abernathy, who frequently made an issue of Clark's position at SCLC's executive staff meeting. ${ }^{824}$ However, Clark remained in SCLC despite "the role of women" being ignored by King and other clerical leaders,

\footnotetext{
820 Ibid., 82.

821 Ibid., 82-83.

822 Ibid., 83.

823 Ibid.

824 Ibid., 77.
} 
because her Christian faith in nonviolence would not allow her to break her affiliation with them; they held to nonviolent tactics regardless of the situation. ${ }^{825}$ She found out that King and the male leaders of SCLC wanted women activists to work behind the scenes, as Coretta Scott King did while her husband was alive. ${ }^{826}$ However, before she began working for SCLC, Clark had already worked with Judge Julius Waties Waring during the 1940s. Waring had desegregated the salaries of public school teachers in South Carolina and had insisted on desegregation in voting rights; his wife had given a speech for racial integration at a YWCA meeting. ${ }^{827}$ Clark also had worked with Virginia Durr, who had worked for the women's liberation movement along with Eleanor Roosevelt. Thus, Clark had an idea for applying the practices of the women's movement to the Citizenship School. ${ }^{828}$ Her intention was revealed by her training of many women leaders in the Citizenship School, such as Hamer, Nash, Ponder, and Bernice Robinson. Clark recognized that, due to the activities of the Women's Political Council, the women of Montgomery took a major role in the Montgomery Bus Boycott, and the Prayer Pilgrimage was organized by women activists in $1957 .{ }^{829}$ Clark evaluated, "I see this as one of the weaknesses of the civil rights movement, the way the men looked at women." 830 Clark's realization of women's equal role in church and society was based on the AME women's movement for their rights.

Clark's civil rights movement's goal for racial integration was shared with her AME Church's tradition, which was one of struggling to reform the evil social system of white racists. In his Prophesy Deliverance! An Afro-American Revolutionary Christianity, Cornel West suggests that DuBois and King developed the "exceptionalist tradition" of African

\footnotetext{
825 Ibid., 78.

826 Ibid., $78-79$.

827 Ibid., 24-26.

${ }^{828}$ Ibid., $80-81$.

829 Ibid., 83.

830 Ibid., 79.
} 
Americans. ${ }^{831}$ According to West, this tradition insists that the natural born or God-given morality of African Americans can overcome white supremacy and cure white people's social evils. ${ }^{832}$ According to West, DuBois's African American superiority was based on the African American Christian tradition that specified the God-given spirit of African Americans in their sufferings and which would expose white people's immorality. West points out that King's philosophy of nonviolence was also rooted in the African American exceptionalist tradition that held that African Americans could redeem white people's evils through their Christian practice of love. ${ }^{833}$ Moreover, West finds a strong exceptionalist tradition in the teachings of R. R. Wright, an AME church bishop who insisted that "African Methodism will carry the Christian message of brotherhood to the white man." 834 West thinks that Wright tried to practice the exceptionalist tradition, through a belief that "only the peaceful, loving, and forgiving Afro-Americans can instill the spirit of Christianity in the violent, vicious white race." 835 As a co-social activist with DuBois and King, Clark expressed her black Christian tradition of exceptionalist in her activities in the NAACP and SCLC. As the president of Wilberforce University, which trained many AME women educators, Wright's writings and messages were well known to contemporary AME people such as Clark.

Sharing the exceptionalist tradition, Clark's nonviolent tactics also aimed at converting white racists. ${ }^{836}$ In 1964, Clark reflected,

I know - and am happier for knowing it - that not all the Negro's improvement of status during the last recent years has been accomplished through his own struggling, his own determination, his own demanding. I know that the white South is changing, too, and changing fast; I know that countless good southern

831 Cornel West, Prophesy Deliverance! An Afro-American Revolutionary Christianity (Louisville: Westminster John Knox Press, 2002), 72-75.

832 Ibid., 72-73.

833 Ibid., 75.

834 Ibid., 74.

835 Ibid.

836 Clark, Echo in My Soul, 215. 
white persons have helped, some through the active championing of our struggle, many others through the quiet acceptance of the fact not only that a new day and a new way must come, but also that they are already here." 837

Clark believed that all human beings are equal children of God; thus, the goal of the civil rights movement is that these children of God will live together and build the "beloved community." 838 Clark insisted that this goal could be achieved only through nonviolence because reconciliation could only be realized through nonviolence. ${ }^{839}$ Acknowledging the need for the women's liberation movement, Clark felt she should practice working for women's rights and for women's leadership in civil rights organizations dominated by men, like the AME women she knew had done. She highlighted that the key people of the HFS and of the civil rights movement were women. ${ }^{840}$ As a college-trained educator who shared the AME women's tradition, Clark tried to awaken poverty-stricken people in Southern local areas to have a self-awareness of voting rights, racial equality, and women's rights as God's children. She also participated in inter- and non-religious social organizations, such as the HFS, more than the black Baptist women did in the WC and SCLC pastors did in the NBC.

\section{Black United Methodist Church Women's Tradition: Bernice Robinson}

Clark recollected that Bernice Robinson played an essential role in strategizing for the Citizenship School. ${ }^{841}$ Robinson was born in Charleston, South Carolina, in 1914, and she was raised there. She was the youngest of the nine children of James C. and Martha Elizabeth Robinson. Her father was a bricklayer who was a stern-looking and strong man. ${ }^{842}$

Robinson's mother was a homemaker and did sewing work at home. Her family was not rich;

\footnotetext{
837 Septima P. Clark, "Septima Poinsette Clark,” 1964, KPKC, 124:5.

838 Clark, Echo in My Soul, 220.

839 Ibid.

${ }^{840}$ Ibid., 123; and Clark, Ready from Within, 83.

841 "Interview with Septima Poinsette Clark" by Eugene Walker, HFS Archives.

842 "Interview with Bernice Robinson" by Sue Thrasher and Elliot Wiggington, November 9, 1980, HFS Archives.
} 
however, Robinson had a happy childhood. ${ }^{843}$ Robinson attended the public schools in Charleston, of which all the students were black. Her father liked to play the organ and other instruments, and he led his church's choir for about fifteen years (or fifty years) ${ }^{844}$ Robinson learned to play the piano and the violin in childhood, and she went to New York after completing her high school courses in 1931 in order to prepare for admission to the Boston Conservatory of Music in Massachusetts. ${ }^{845}$ When she attended the public schools, Robinson taught little poor kids the alphabet and spelling every summer. She thought that this experience helped her make the decision to become the first teacher of the HFS's Citizenship School when she was older. ${ }^{846}$ Robinson went to New York because some of her brothers and sisters lived there, and her godmother was in Boston. She tried to save up money for tuition for the Boston Conservatory of Music while she stayed with these people. However, her mother became ill, and Robinson had to go back to Charleston to care for her mother.

Giving up her dream of being a music college student in Boston, Robinson went back home and married. Robinson gave birth to a daughter, but her husband lost his job as a waiter and left Charleston to find another job. He soon stopped sending money, and Robinson had to go to work as a maid at the hunting resort on Bulls Island. ${ }^{847}$ This job made her mother and father sad because they had never allowed their children to work for white people as maids or

\footnotetext{
843 Ibid.

${ }^{844}$ Ibid. In the original manuscript, it is uncertain to discern between the letter of fifty and that of fifteen because the letters are battered.

845 Ibid. In her interview, Robinson consistently called the unconfirmed music college "the Boston Conservatory of Music," but she might have been referring to the New England Conservatory of Music in Boston, which had the first African American woman graduate in 1924, before Robinson graduated from her high school. See Polly Welts Kaufman, Jean Gibran, Sylvia McDowell, and Mary Howland Smoyer, Boston Women's Heritage Trail: Seven Self-guided Walks Through Four Centuries of Boston Women's History (Boston: Boston Women's Heritage Trail, 2006), 80.

846 "Interview with Bernice Robinson," by Sue Thrasher and Elliot Wiggington, November 9, 1980, HFS Archives.

847 Ibid.
} 
errand boys. However, Robinson tried to be a realist in order to feed her family. ${ }^{848}$ Robinson finally divorced and went to New York again to find a job and gain more education because she could only make a dollar per day at domestic jobs in Charleston, despite working seven days a week. ${ }^{849}$ About 1936, Robinson asked her mother to take care of her daughter, and she went to New York. While she lived in Harlem, Robinson worked for the garment industry and attended night classes to achieve a certificate as a cosmetologist. ${ }^{850}$ Working in the garment industry, she could make a maximum of $\$ 45$ per week. When this work slowed down during the winter season, Robinson took a job at a drapery factory. She attended Pace College in New York to study real estate brokerage. ${ }^{851}$ She also registered to vote in New York and took the Civil Service exams in New York and Philadelphia. ${ }^{852}$ She brought her daughter to New York to get a better education, and she got a job at the United States Treasury Department, where she could make seventy-five dollars per week. ${ }^{853}$ However, due to her mother's sickness, Robinson had to go back to Charleston in 1947.

Robinson's years in New York opened her eyes to the possibility of living in an integrated society. During those years in New York, Robinson experienced racial integration and well-paying jobs for the first time in her life. ${ }^{854}$ She could sit anywhere on the buses and in the theatres in New York, and she could eat at some exclusive restaurants. Moreover, Robinson found out that she could eat at segregated restaurants in New York by pretending to be an African American dignitary or foreigner. She could enjoy the musical concerts at Carnegie Hall, Town Hall, and the Apollo Theatre and meet with famous musicians, such as

\footnotetext{
${ }^{848}$ Ibid.

849 Ibid.

850 Ibid.

851 Bernice Robinson, “Bernice V. Robinson Four Page Resume,” AMN 1018, 1:4.

852 "Interview with Bernice Robinson," by Sue Thrasher and Elliot Wiggington.

853 Ibid.

854 Ibid.
} 
Dean Dixon and Duke Ellington. ${ }^{855}$ Robinson discovered that black people could register to vote and run for public office. She could make friends with Germans, Armenians, and Jews. Her experience of living as a self-made career woman in the integrated society of New York City prepared her to be a teacher at the HFS's Citizenship School and to provide her local black students with a vision of better job opportunities, economic situations, and educations through first-class citizenship. ${ }^{856}$

Robinson had attended and been a member of the Old Bethel United Methodist Church in Charleston since childhood. ${ }^{857}$ This church was the same church that Clark had attended during her childhood. Clark testified that one of the major reasons why she encouraged her cousin Robinson to join the HFS workshop and to be the first teacher of the Citizenship School was because Robinson's mother was worried about Robinson not attending church after she came back from New York. ${ }^{858}$ Clark believed that Robinson would like it more if she were working for the people in her community than participating in the usual church volunteer work. Clark thought that working for the HFS could be an alternative religious option for Robinson, since she would be serving illiterate and marginalized local black people, just as Jesus instructed his disciples to sacrifice themselves in service to their neighbors in need. ${ }^{859}$ As Clark described, temporarily, Robinson might not have been enthusiastic about being an active church member after she returned from New York; however, during and after her work at the HFS, she became active in her church and Christian organizations. She served as "chairman of the administration board" at Old Bethel United Methodist Church for five years, as "captain of one group for the Building Fund" of the

\footnotetext{
855 Ibid.

856 Ibid.

857 Bernice Robinson, "Bernice V. Robinson Four Page Resume,” AMN 1018, 1:4.

858 "Interview with Septima Clark" by Sandra Brenneman Oldendorf, January 17, 1986, HFS Archives.

859 Ibid.
} 
church, as "co-chairman of the annual conference board of Christian Social Concern," as a member of the "Board of Missions, S.C. Conference, United Methodist Church," and as "president of United Methodist Women." 860

Robinson also demonstrated that her social activities were based on her Christian faith. She understood that "voting is not merely a civic duty. It is a religious obligation." 861 According to her belief, "Just one vote per precinct could throw an election to the wrong person." that millions of God-fearing Americans are guilty of committing." ${ }^{\text {"63 }}$ She highlighted that every citizen had a responsibility to compose the government and to affect its conduct. ${ }^{864}$ If one citizen was flouting the opportunity to vote, Robinson thought that he or she was indifferent to the welfare of millions of people who could live in better circumstances. ${ }^{865}$ Moreover, Robinson challenged black people to vote because they had been patient in winning the right to vote, and "the price we paid to win the opportunity to vote was too high for us to ignore and be complacent." 866 Robinson tried to focus on the value and importance of voting rights that black people had achieved as their God-given rights. She also insisted that the voting rights of black citizens were not only capable of protecting personal rights but also capable of empowering their neighbors' welfare. For instance, Robinson demonstrated that there could be one black person who could be elected as a House member in Charleston and six black people on the city council after black people abolished segregation in voting in

860 Bernice Robinson, "Bernice V. Robinson Announces Her Candidacy," 1972, AMN 1018, 1:13; Bernice V. Robinson to Woodie White, November 19, 1971, AMN 1018, 10:3; "Bernice V. Robinson Four Page Resume," AMN 1018, 1:4; and Avery Research Center at the College of Charleston, "Bernice V. Robinson Biography," AMN 1018, 1:1.

861 Bernice Robinson, "Political Education/Working with Blacks in Rural South Carolina," 1972, AMN 1018, 1:13.

862 Ibid.

863 Ibid.

864 Ibid.

865 Ibid.

866 Ibid. 
$1970 .{ }^{867}$ Robinson realized that this powerful right could protect the God-given rights of underprivileged people, thus, she claimed, "voting is a religious and moral obligation." 868 Robinson's Christian faith in God-given rights and the religious obligation to vote corresponded with the faith of Sojourner Truth, whose story Robinson told in the section on African American history in the Citizenship School workbooks. Truth was converted to Methodist Christianity and worked for a Methodist congregation during most her life, even though she frequently participated in meetings of the African Methodist Episcopal Zion Church, the Seventh-day Adventists, and the Religious Society of Friends. ${ }^{869}$ After her conversion experience in 1828 , Truth confessed, "I was civilized not by the people, but by Jesus." ${ }^{\prime 870}$ When she became a celebrated American prophet, Truth delivered many biblically-based sermons and wrote letters requesting abolition and the rights of colored people. Truth preached, "With God's blessing, they [poor colored people] might yet become an honor to the country which had so cruelly wronged them." ${ }^{871}$ She appealed to the government to build a hospital for colored people and requested that the president abolish "the Jim Crow car," the segregated streetcar. ${ }^{872}$ Truth's preaching and mission were accompanied with requests for the equal rights of segregated people because she believed that black people were worthy to be blessed by God, who gave them the same rights as creatures of God as white people. ${ }^{873}$ Just as Truth's gospel messages could not be disconnected from

\footnotetext{
867 Ibid.

868 Ibid.

${ }^{869}$ Carleton Mabee and Susan Mabee Newhouse, Sojourner Truth: Slave, Prophet, Legend (New York: New York University Press), 23-25, 240.

870 Ibid., 22.

871 Henry Louis Gates, Jr., ed., Narrative of Sojourner Truth, A Bondswoman of Olden Time, with a History of Her Labors and Correspondence Drawn from Her "Book of Life" (New York: Oxford University Press, 1991), 198.

872 Ibid., 183-184.

873 Ibid., 218.
} 
restoring God-given rights to oppressed people, Robinson's social activities could not be separated from insisting that Christian faith supported equal rights for black people.

In her letter to Bishop Peter Mark Kariuki Wachira in Kenya, East Africa, Robinson recalled her life: "I am devoted to the Christian way of life and attempt to follow the life of Christ, by walking each day with poor people in our country, to bring about relief from Poverty and Want." ${ }^{874}$ Robinson highlighted the common mission of Christians, the importance of which had to be shared by all Christians. She believed that American Christians needed to work together in a faith that enabled them to accomplish "the Fatherhood of God and the Brotherhood of man." 875 Thus, Robinson believed that the Christian mission should not be limited to her life but shared with every Christian. She insisted that it was not only "my Christian mission" but also "our Christian mission" to feed the hungry, to provide shelter for the homeless, and to get medical care for the ill. ${ }^{876}$ Robinson's description is a key to understanding her life: she had worked for the HFS and the CEP to help underprivileged people, and she had provided public services for eliminating poverty through AmeriCorps VISTA (Volunteers in Service to America) after 1971. As a career woman, when Robinson came back to Charleston from New York, she began working for local community people and continued doing so for the rest of her life. Her dedication was based on her Christian faith that tried to follow the life of Jesus, and she worked hard to share the Christian mission through training local community people to realize its importance.

Concerning the sufferings of black people as they sought to achieve freedom, Robinson interpreted that God does not promise his people easy ways. ${ }^{877}$ She thought that following

${ }^{874}$ Bernice Robinson to Peter Mark Kariuki Wachira, January 2, 1973, AMN 1018, 1:16.

875 Ibid.

876 Ibid.

877 Ibid. 
the life of Jesus is hard, as much as entering the narrow gate and walking the rough ways; however, she believed that Christians who suffered should not fear because God promises to be with them. ${ }^{878}$ Thus, even though there were sufferings and violence against black people, Robinson believed that Jesus was walking with them, and their patience for peace led unjust people to be changed. ${ }^{879}$ Robinson thought that teaching black history was essential to developing the racial identity of the students of the Citizenship School. Through teaching black history, Robinson understood that the civil rights movement went back to the movement of Harriet Tubman in the early $1800 \mathrm{~s} .{ }^{880}$ She highlighted that Tubman helped fugitive slaves through the Underground Railroad and was "the only woman in American history" to lead a military raid (on Harpers Ferry, Virginia). ${ }^{881}$ Robinson also insisted that black women activists were in the majority during the civil rights movement, which had been developed from the years of Tubman to the 1930s. She understood that women civil rights activists had struggled for the rights of black people and women. ${ }^{882}$ Robinson taught her students that black women activists developed women's clubs to improve housing, education, and economics for black people, and they established the National Association of Colored Women in 1896 to fight against lynching and racism. ${ }^{883}$ Robinson insisted that black women should raise their voices for their rights during the civil rights movement, as black women had been struggling during the two hundred previous years. ${ }^{884}$ Robinson asserted that the voting rights movement was partaking of these women's courageous and active civil rights

\footnotetext{
${ }^{878}$ Ibid.

879 Ibid.

880 Bernice Robinson, “The Early Days of the Civil Rights Movement,” AMN 1018, 1:14.

881 Ibid.

882 Ibid.

883 Ibid.

884 Ibid.
} 
movement. She believed that God guided black people with love and care during these struggles. $^{885}$

In her 1969 typescript titled "Women," Robinson emphasizes the gender identity of black women as she interprets the civil rights movement as a women's movement. ${ }^{886}$ She describes women as the people who were strong enough to "create a world where their loved ones can grow stronger and more love filled." ${ }^{887}$ Robinson thought that women's strength and love had changed the world for their children and their neighbors. This image of women as frontiers-women reflected the lives of Harriet Tubman, who was the only woman leader of a military raid against slavery, and Robinson herself, who was the first teacher of the Citizenship School and the first black candidate for the South Carolina House of Representatives. As Clark did at SCLC and the Citizenship School, Robinson placed women as the main factor in integrating people of different races, ideas, and environments through their encouraging people to share fellowship with each other. ${ }^{888}$ While Hamer and Parks helped the civil rights movement share deeper human dignity and emotion, Robinson identified women as the people who are "ready to respond to joy/to sorrow/to love with all they are capable of." 889 Robinson also pictured women as the people who are able to steadily prepare for the future with balance and responsibility. ${ }^{890}$ Robinson's idea of the identity of women, who nurture the younger generation and change the world through strength and love, coincides with the life of Jesus that Tubman and Robinson herself attempted to follow.

Truth also represented the image of a frontiers-woman who was able to challenge politicians and national leaders such as President Abraham Lincoln and Frederick Douglass.

\footnotetext{
885 Ibid.

886 Bernice Robinson, "Women,” November 1969, AMN 1018, 5:1.

887 Ibid.

888 Ibid

889 Ibid.

890 Ibid.
} 
In her powerful 1851 speech “Ar'n’t I a Woman?,” Truth pioneered the call for the equal rights of women: "I am a woman's rights. . . I have heard the bible and have learned that Eve caused man to sin. Well if woman upset the world, do give her a chance to set it right side up again. . . And how came Jesus into the world? Through God who created him and woman who bore him." 891 Robinson shared Truth's concept of womanhood, which has the power to change the world into a place that respects the equal rights of women. The Methodist Church women developed the frontiers-women tradition that recognized women as the main factor in changing the unjust world and restoring the rights of unprivileged people, just as Truth, Tubman, and Robinson raised their voices when most people were silent. In comparison to the black Baptist women, who had been patient with their auxiliary position in the NBC while they demanded their rights to have leadership, the black Methodist women's frontiers-women tradition pioneered the proclamation of women's equal rights in spite of the ignorance of the male-dominated leadership of the church and the society.

As she described the identity of women in her typescript as the independent main body of the civil rights movement, Robinson began to participate with the social movement as the Secretary and Chairperson of Membership of the NAACP Charleston branch in 1947. When she worked for the NAACP, Robinson ran her beauty shop at home and encouraged her customers to join the NAACP. ${ }^{892}$ She brought in over seven hundred new members when the membership previously stood at about three hundred. ${ }^{893}$ Even though being a member of the NAACP meant taking the risk of being fired from one's job during the 1940s, Robinson could promote joining the organization because she owned her own business. ${ }^{894}$ When her father died in 1950, Robinson finally realized he was a NAACP member because she found

891 Gates, Narrative of Sojourner Truth, xxxiii.

892 "Interview with Bernice Robinson" by Sue Thrasher and Elliot Wiggington, November 9, 1980, HFS Archives.

${ }^{893}$ Ibid.

${ }^{894}$ Ibid. 
his membership card in his papers. ${ }^{895}$ When she retired from the CEP in 1970, Robinson was hired by the South Carolina Commission for Farm Workers, Inc. (SCCFW) for working as the supervisor for the volunteers of the VISTA. Robinson was the first African American woman to run for the South Carolina House of Representatives in 1972 and 1974. In 1975, Robinson worked again for the SCCFW as the director of Migrant Day Care. ${ }^{896}$ She worked as the Loan and Relocation Officer of the Charleston County Development Department from 1979 to 1982 . Robinson attended the University of Wisconsin from 1966 to 1968 and majored in community development. Living like a black frontiers-woman in a segregated society, Robinson's education and careers, including continuously working as a social activist from 1947 to 1982, demonstrate her self-determination as a black woman.

Robinson's denominational background was the United Methodist Church, from her lifetime of attending the Old Bethel United Methodist Church in Charleston. With the third oldest church building in Charleston, this church was initially open to having a black congregation in 1797. However, Methodists came to support abolition, which was widespread in Charleston during the early 1800s. There was a schism in 1834 in the congregation because some white congregants supported the segregation of seats in the church's galleries. ${ }^{897}$ Keeping the church's original name, the black congregation of the Old Bethel United Methodist Church seceded to establish their own church in the far west part of the church's lot in $1842 .{ }^{898}$ The white congregation built their new church in the original portion of the lot in 1852 and renamed their congregation Bethel Methodist Church. ${ }^{899}$ The schism of the Old Bethel United Methodist Church was similar to that of Richard Allen's congregation, which

\footnotetext{
895 Ibid.

896 Bernice Robinson, "Bernice V. Robinson Four Page Resume," AMN 1018, 1:4.

897 Frank Karpiel, Charleston's Historic Cemeteries (Charleston: Arcadia Publishing, 2013), 96.

898 National Park Service, U.S. Department of the Interior, "Old Bethel United Methodist Church," https://www.nps.gov/nr/travel/charleston/obm.htm. 899 Ibid.
} 
seceded from St. George's Methodist Episcopal Church and established the AME church. The struggle of the Old Bethel United Methodist Church impacted the formation of the selfdetermination of Robinson's parents, who never used an honorific title such as "Mr." or "Sir" to address a white man. ${ }^{900}$ With her church background, Robinson taught her students about Sojourner Truth and Harriet Tubman, who were dedicated to the abolitionist movement and shared black Methodist church backgrounds. ${ }^{901}$

Despite the hierarchical and male-dominated administrative leadership of the United Methodist Church, from 1968 to 1990, Theressa Hoover led the Women's Division to restructure the United Methodist Church in line with the women's liberation movement of most liberal Protestant denominations. ${ }^{902}$ In 1968, Hoover's Women's Division publicly insisted that women should be involved in all the structures of the United Methodist Church, including committees for policy-making, management, and leadership. ${ }^{903}$ Hoover was able to develop a feminism that could promote women's leadership and the provision of funds for the autonomy of women's activities in the United Methodist Church. ${ }^{904}$ She did not encourage women to take over the male leadership but to fight against the social oppression of women and black people. ${ }^{905}$ Like Robinson, who studied to become a professional career woman, Hoover majored in business administration for her bachelor's degree and in human relations and social policy for her master's degree. Sharing Robinson's participatory zeal, Hoover served on the executive board of the National Council of Negro Women and the National

900 "Interview with Bernice Robinson" by Sue Thrasher and Elliot Wiggington, November 9, 1980, HFS Archives.

901 Harriet Tubman had an African Methodist Episcopal Zion Church background, which shared the root of black Methodism. See Collier-Thomas, Jesus, Jobs, and Justice, 70.

902 Rosemary Skinner Keller and Rosemary Radford Ruether, eds., Encyclopedia of Women and Religion in North America (Bloomington: Indiana University Press, 2006), 15.

903 Ibid.

904 Ibid.

905 Collier-Thomas, Jesus, Jobs, and Justice, 465. 
Board of the YWCA. Hoover also was interested in training young women and establishing a scholarship to support young black women's studying.

Just as Truth, Tubman, and Hoover dedicated their lives to fighting for the rights of women and black people based in their black Methodist Church backgrounds, Robinson successfully achieved the voting rights of black people through her grassroots movement. Sharing the black Methodist women's tradition of leadership in the civil rights movement, Robinson taught her Citizenship School students black women's history, including the stories of Truth and Tubman. Living as career women, Hoover's and Robinson's lives show the selfdetermination of black Methodist women who concentrated on educating future generations. These women recognized the male-dominated structures in their churches, institutions, and society, and they tried to restructure these systems to accept women's leadership. These black Methodist women developed self-awareness of the power of their womanhood to change an unjust society through love and care. Robinson's strong enthusiasm for educating grassroots people and having an autonomous life coincides with the tradition of black Methodist women. They had developed stronger independent images of womanhood and an earlier tradition of frontiers-women than other black denomination church women, such as the black Baptist church women. Moreover, as the pioneers of womanhood, the black Methodist women requested the full, independent rights of women in the church and in society earlier than other women of the major black church denominations did.

\section{Black Catholic Women's Tradition: Diane Nash}

Diane Nash grew up in a middle-class Catholic family in Chicago and was taught by nuns in Catholic schools. Through the influence of her Catholic education, she developed a hope of becoming a nun. ${ }^{906}$ As her grandmother instructed, Nash could pass as white because

906 Olson, Freedom's Daughters, 153. 
of her light skin during her childhood. ${ }^{907}$ Nash and her grandmother were the first Catholics in their family, and her grandmother taught her about human dignity, which led her to participate in the civil rights movement, even though her grandmother did not intend for her to join the movement. ${ }^{908}$ When she attended high school in 1956, Nash participated in the beauty contest for Miss Illinois and was elected as a runner-up. ${ }^{909}$ She transferred colleges from Howard University to Fisk University and joined James Lawson's workshop, which introduced her to the HFS. Nash was one of the leaders of the Nashville sit-ins and SNCC. Her serious Catholic faith from her childhood, which educated her to be faithful without lying, also inspired her to join the civil rights movement, which was seeking for the truth of human dignity. ${ }^{910}$ After she worked on the Freedom Rides and sit-ins, Nash tried to relinquish the fixed ideas of her Catholic faith that she had obtained in childhood. ${ }^{911}$ After two or three years of being free from the Catholic religion, Nash found her own way of being spiritual that was "being truthful with myself." 912 Nash newly recognized that truth and love without the limits of Catholic faith could guide her involvement in the civil rights movement. ${ }^{913}$ When she learned about Gandhi's nonviolent resistance, Nash realized that nonviolent resistance was related to her spiritual life, and spirituality and nonviolent resistance were interrelated with each other. ${ }^{914}$

There was another reason why Nash did not want herself to be shackled by the Catholic Church's system during the civil rights movement—she had a problem getting the church's

907 Ibid., 152.

908 Heidi Hall, "Years After Change, Activist Lives Her Convictions," USA Today, March 26, 2013.

909 Nash testified that she took part in two or three beauty contests during her late teenage years. See "Interview with Diane Nash," by Taylor Branch, April 26, 1990, TBWL, 77:537. 910 Ibid.

911 Ibid.

912 Nash did not quit attending Catholic mass during this period. See "Interview with Diane Nash."

913 Ibid.

914 Ibid. 
permission to marry James Bevel, who was a Baptist preacher. ${ }^{915}$ Bevel strongly wanted to stay with his Baptist church background, and her Catholic church might excommunicate her if she married a Baptist man. Nash and Bevel finally married civilly in 1961, and they worked with the mass movements and the workshops for voter registration drives in Mississippi. ${ }^{916}$ Even though Nash knew that Bevel had committed adultery with many women a few months into their marriage, she hesitated to divorce him because her Catholic family members would not understand her getting a divorce, and their relationship was influential to the development of the movement. ${ }^{917}$ Just as she had learned from the nuns of her Catholic school that religious vows meant a lifetime of dedication, Nash often confessed that she had dedicated her life to the civil rights movement; thus, she finally divorced Bevel after seven years of marriage, when they were finished working together on major campaigns, such as the sit-ins, the Freedom Rides, the voting rights movement, and the anti-Vietnam War campaign. ${ }^{918}$ Nash and Bevel won SCLC's Rosa Parks Award for their contributions to the success of the voter registration drive in Alabama and to the Selma to Montgomery marches.

Nash's Catholic faith impacted her interpretation that the civil rights movement was a moral fight. ${ }^{919}$ She confessed that her Catholic faith influenced her "telling the truth" in public and in the courts when she had to witness about her struggles for civil rights. ${ }^{920}$ Nash did not strictly follow the doctrines and dogmas of Roman Catholicism; however, because there were noticeable subcultural impacts of Catholicism on American Catholics, such as concepts of Catholic moral community, of being a "moral guardian" of American society

\footnotetext{
915 Ibid.

916 Ibid.

917 Ibid.

918 Heidi Hall, "Years After Change, Activist Lives Her Convictions"; and John Deedy, American Catholicism: And Now Where? (New York: Plenum Press, 1987), 147.

919 Diane Nash, "A Message to Individuals and Organizations Working for Civil Rights," April 30, 1962, KPKC, 123:43.

920 "Interview with Diane Nash."
} 
through education, and of having the power of the largest religious denomination in America, Nash's concept of the moral fight for civil rights reflected Catholic influences on her thinking. ${ }^{921}$ As she tried to be a moral guardian for the American community, Nash fought for the beloved community in which all evil powers had been evicted without negotiation. ${ }^{922}$ She recognized that racism was not only an individual evil in communities but also a systematic evil of communities. Thus, Nash's fights for civil rights targeted the redemption of communities, not the reformation of fractional social problems.

Since she refused to negotiate until systematic evil was removed, when Nash was sentenced to two years in jail for conducting workshops for youth in Jackson, Mississippi, Nash made a decision to practice "jail-no-bail" resistance by not paying the $\$ 2000$ fine. ${ }^{923}$ She proclaimed, "I can no longer cooperate with the evil and unjust court system of this state." 924 Supporting nonviolence philosophy, Nash defined its meaning thus: "This is one of the basic tenets of nonviolence - that you refuse to cooperate with evil." ${ }^{925}$ She claimed that she would never leave jail without the "unjust and untrue charges against me" being dropped. ${ }^{926}$ She pointed out that the segregated courts humiliated the human dignity of black people and asked black people to pay for the humiliation. ${ }^{927}$ Most of all, Nash insisted that black people should resist the segregated system because they should not lose the opportunity to "reach the community and society with a great moral appeal and thus bring about basic changes in people and in society." 928 She believed that if black people could stand on "a

921 Chester Gillis, Roman Catholicism in America (New York: Columbia University Press, 1999), 2, 161, 176.

922 "Interview with Diane Nash."

923 Diane Nash, "They Are the Ones Who Got Scared," in Holsaert et al., eds., Hands on the Freedom Plow, 78.

924 Diane Nash, "A Message."

925 Ibid.

926 Ibid

927 Ibid.

928 Ibid. 
moral principle," their community and the whole world could be awakened and moved into a new phase. ${ }^{929}$ Nash insisted that the moral fight of the black people should be done according to their own conscience, which enabled them to make their own decisions and bring about "the redeemed society." 930

The Catholic Church in the United States was mostly segregated until the middle of the twentieth century, even though there were official orders of black nuns and Catholic organizations run by white Catholic priests for the benefit of black people, such as the Oblate Sisters of Providence and the Sisters of the Holy Family. ${ }^{931}$ In 1917, however, black laywomen and laymen of the Catholic Church organized nationally under the name Federated Colored Catholics. ${ }^{932}$ This organization developed an integrated seminary, St. Augustine's Seminary, which promoted black priests, published their own journals, and ran forums for eliminating racism within the Catholic Church of America. ${ }^{933}$ The activities of the organization lasted until the 1950s. In his article "Relating Race and Religion" in Uncommon Faithfulness: the Black Catholic Experience, Albert J. Raboteau analyzes the activities of the Federated Colored Catholics as a "model of religion transcending race" because they were the actions of black Catholics who tried to practice their belief in the universal Catholic Church by embracing all colored people in the world as members of the "one, holy, apostolic and catholic" church. ${ }^{934}$ The Federated Colored Catholics shared Nash's faith in the beloved community that embraces all colored people as equal members and that shares in the oneness of an integrated community.

\footnotetext{
929 Ibid.

930 Ibid.

931 Collier-Thomas, Jesus, Jobs, and Justice, 68; and Stephen J. Ochs, Desegregating the Altar: The Josephites and the Struggle for Black Priests, 1871-1960 (Baton Rouge: Louisiana State University Press, 1990), 6-8.

932 M. Shawn Copeland, ed., Uncommon Faithfulness: The Black Catholic Experience (Maryknoll: Orbis Books, 2009), 2.

933 Ochs, Desegregating the Altar, 5.

934 Copeland, Uncommon Faithfulness, 16.
} 
While Nash was educated in a Catholic school with Catholic nuns for teachers, Catholic schools that had been founded by black women had been building an educational tradition since the nineteenth century. The Oblate Sisters of Providence was founded by black Catholic women in 1828, during the antebellum era when white supremacy was dehumanizing black people. The Oblate Sisters was organized to educate poor black girls in Baltimore, Maryland. During the antebellum era, the Catholic Church in the United States followed the Southern tradition of racism and supported slavery according to its founding background in the South. ${ }^{935}$ Father James Joubert approved the Oblate Sisters as the first community of black Catholic sisters. ${ }^{936}$ Working as teachers, the Oblate Sisters broke the stereotypical images of black women, such as "Mammy," which sneered at the image of the obedient slave who took care of the white family while neglecting her own children, and "Jezebel," which symbolized the lust and wickedness of black woman. ${ }^{937}$

Even though the Oblate Sisters did not officially proclaim support for or against slavery, they pursued the goodwill of everybody and established the Oblate School for Colored Girls in 1828. ${ }^{938}$ Through their educational endeavors, the Oblate Sisters highlighted educating black girls in the virtues of keeping their manners, self-respect, and morality. ${ }^{939}$ Despite threats to close their school, the Oblate Sisters continued to teach their students about racial identity. This community proclaimed St. Benedict the Moor, who was a son of African slaves, as one of their special patrons, and they developed the feast of St. Benedict. The Oblate Sisters expanded their activities of helping the poor and sick by contacting and learning from the European Redemptorists. ${ }^{940}$ The Oblate Sisters of Providence serve as an

\footnotetext{
935 Ibid., 27.

936 Ibid.

937 Ibid., 29.

938 Ibid., 31.

939 Ibid.

940 Ibid., 37.
} 
example of a religious women's community that broke through the limits of social orders through their own realization of racial and gender virtues. They also built the black Catholic women's tradition of helping and living with poor people in local areas as part of their religious vocation. ${ }^{941}$ During her work for the Citizenship School programs and the voting rights drives, Nash reflected this Catholic women's tradition by living in local communities to train illiterate people how to gain their voting rights. ${ }^{942}$

Another historical event in American Catholics' struggle with segregation and racism happened in North Carolina. Bishop Vincent S. Waters announced a desegregated diocese in Raleigh, North Carolina, in 1951. Before Bishop Waters's announcement, there was strong segregation in Catholic schools and church buildings in Raleigh. Bishop Waters realized that the segregation in the churches of Raleigh was based on the Jim Crow laws, and he declared that this segregation was a heretical practice against the Catholic faith. ${ }^{943}$ Bishop Waters insisted that the Catholic faith supports the equal rights of every race. White parishioners of Raleigh strongly refuted Bishop Waters's declaration, which blocked black and white parishioners from attending worship services and refuted the Southern order of segregation. ${ }^{944}$ Even though the white racist parishioners accused Bishop Waters of being a communist, betrayer, and tyrant against Southern culture, he admonished them to practice Christian love, which never had racial prejudice. Despite losing some church members and harsh criticisms, Bishop Waters finally initiated the official desegregation of the Diocese of Raleigh in 1953.

Even though American Catholics were not recognized as active participants in the civil rights movement until King called the clergy of America to join the Selma to Montgomery

941 Ochs, Desegregating the Altar, 26.

942 "Interview with Diane Nash."

943 Copeland, Uncommon Faithfulness, 65.

944 Ibid. 
marches, there had been dedicated black Catholics struggling to keep their racial and gender identities in the history of black Catholicism in the United States. During the late 1960s, Sister Barbara Ann Moore, who was one of the enthusiastic marchers in the Selma to Montgomery marches, raised her voice of "Black Nun Power," which challenged black Catholic women to fight against injustice in their religious and secular societies. ${ }^{945}$ The Oblate Sisters of Providence, which worked to develop education for black girls and the values of black women, serves as background for Diane Nash's racial and gender identity, which gave everybody equal rights as God's children. When Nash decided to be jailed without paying bail while expecting her first child's birth a month later, she confessed, "I believe that if I go to jail now it may help hasten that day when my child and all children will be free- not only on the day of their birth but for all of their lives." 946 This statement by Nash shares commonality with the activities of the Oblate Sisters of Providence, who had worked to affirm the racial identity of young black girls and to prepare them to mother future generations. Nash's dream of establishing an integrated society, "the redeemed society," corresponded to the activities of the Federated Colored Catholics and Bishop Waters's struggle to desegregate a diocese because of his Catholic faith. ${ }^{947}$ Nash differed from the hierarchical Baptist leaders of SCLC through her fight for an integrated community that was based on her image of serving as a moral guardian that did not negotiate with the evil system of American society. She also lived with local people to train them to exercise their rights, thus using the horizontal leadership style of the Oblate sisters. Having a morality based on Catholic faith, Nash was an initiator and promoter of the Nashville sit-in, the Freedom Rides, the voting rights and nonviolence workshops in Birmingham and Mississippi, the Selma to Montgomery marches, and the anti-Vietnam War campaign.

945 Collier-Thomas, Jesus, Jobs, and Justice, 462-463.

946 Diane Nash, "A Message."

947 Ibid. 
All of these women leaders, who were graduates of the Citizenship School and operated it, had a unique experience of helping and changing grassroots people as Christian women. Based on their denominational church traditions, Christian women leaders of the Citizenship School developed their church's traditions of women's independent movements that had struggled with racial and gender inequality. Women leaders of the Citizenship School realized that the civil rights movement was not only a temporal movement of the middle of the twentieth century but also an ongoing movement of black women and men who had been fighting for abolition, freedom, and racial and women's rights throughout slavery and the post-Civil War eras. Even though they had been marginalized from the administrative structures of church denominations until the middle of the twentieth century, as pioneers promoting the rights of the marginalized, black church women initiated independent church women's organizations and clubs for educating the future generation and helping people in need.

Compared to the male clerical civil rights leaders of SCLC, the women leaders of the Citizenship School were mostly career women who had experienced more directly social injustice, poverty-stricken people, and illiterate people in local areas than the male clerical leaders, who mostly worked in their church offices. From their real-life experience in the field, black women leaders of the Citizenship School were able to respond to the social problems of local people in practical ways. Women's movements of self-help and selfdetermination for their rights had been developed in the fields of the diverse church denominations, and women leaders of the Citizenship School applied the Christian values of racial and gender equality from the women's movements to their educational programs for promoting grassroots leadership. Unlike male clerical leaders' speeches and tactics of holding mass meetings that focused on utilizing dogmatic church messages, women leaders of the Citizenship School provided local people with realistic tactics and explanations for 
nonviolent resistance against violent racists' reprisals and police brutality. The women leaders of the Citizenship School were able to awaken local black people because, as sharers in the black church women's independent tradition of pursuing racial and gender identity, they adopted the practical tactics of education and economic development. They followed in the footsteps of the diverse traditions of black Baptist women's national organizations for the self-reliance of local black communities, AME women's independent movements for equal rights, black Methodist women's strong fights for freedom, and black Catholic women's activities to educate young people and bring about racial integration. 


\section{Chapter Four}

\section{The Citizenship School: \\ From the Birmingham Campaign to the Selma to Montgomery Marches}

Also, implicit in our program [Citizenship Program] was the belief that more and more would be involved in the total program of the movement. I don't think it is an exaggeration to say that the Citizenship Program has laid the groundwork for SCLC's entire program and staff. ${ }^{948}$

The Citizenship School program of the CEP and the HFS took the lead of the civil rights movement during the 1960s through major organizations such as SCLC, SNCC, COFO, and the NAACP. After the Albany Movement, there was a clear transition of leadership from the hierarchical leaders to the people of the Citizenship School, who strategized the grassroots communities. The major civil rights activities from 1963 to 1965 , which were the Birmingham Campaign, the March on Washington, the Freedom Summer, and the Selma to Montgomery marches, were mainly carried out by the trainees of the Citizenship School program. The grassroots leadership, which was developed by these movements, was a horizontal leadership that enabled the participants to be trained as leaders using the tactics of empowering self-awareness of their human rights. Through the Citizenship School program, the grassroots leaders were given authority by the voluntary purposes of the movements, not by hierarchical orders from top leaders. The strategists of these movements were Septima Clark, Dorothy Cotton, Diane Nash, Fannie Lou Hamer, James Bevel, Andrew Young, Bob Moses, John Lewis, and Hosea Williams. The crucial difference of Clark's grassroots leadership from King's top-down leadership bred multiple key leaders, who were able to work close to the grass roots and to organize major movements with local people. These voting rights activists were able to successfully bring about the Civil Rights Act of 1964 and the Voting Rights Act of 1965 from the foundation of their grassroots movements in their Citizenship School program.

948 Young to Hotchkiss, June 10, 1964, KPKC, 136:14. 
During the 1960s, civil rights organizations came to learn the importance of educating and strategizing with civil rights activists and community people. As Andrew Young pointed out after the Albany Movement, "We also learned that passion and enthusiasm were no substitute for sound, strategic planning." ${ }^{949}$ SCLC and SNCC had realized that their civil rights activities, such as boycotts, sit-ins, and Freedom Rides, faced the limit of covering all the diverse problems of segregated African Americans. The various civil rights organizations also had difficulties with focusing and solidifying their movements' alliances with other organizations. The Citizenship School could be the factor that unified the diverse civil rights movements around a solid topic, that of voting rights, and it could enforce the communications of the different civil rights organizations around the ultimate shared goal of achieving the first-class citizenship of black people. This chapter delves into the process and results of developing the Citizenship School program through the major civil rights organizations and into how the Citizenship School program worked to shape civil rights activities, from the Birmingham Campaign to the Selma to Montgomery marches. Moreover, this chapter examines how the Christian women leaders of the Citizenship School program expanded their influence on the major movements and changed the hierarchical leadership structure into grassroots leadership for the civil rights movement, beginning with the Birmingham Campaign.

\section{The Birmingham Campaign and the Citizenship School}

The Albany Movement exposed the hierarchical leadership problem of SCLC and its affiliated organizations. Through the unpredicted withdrawal of SCLC's top leaders from the Albany Movement, the movement helped civil rights activists realize the need to change the top-down leadership structure into a bottom-up one. From November 1961 to August 1962, Charles Sherrod, Cordell Reagon, and Charles Jones, who came to establish a voter 
registration drive in Albany as SNCC members, led local activists to test the racial integration of all bus terminals by the Interstate Commerce Commission (ICC). Along with increasing the effects of the Freedom Rides that CORE had initiated, they tried Freedom Rides to examine the ICC, which was required to desegregate interstate transportation as a result of the 1960 Boynton v. Virginia decision of the Supreme Court. ${ }^{950}$ Beginning with the jailing of six students from SNCC, who tried to use the sections reserved for whites on transportation vehicles, hundreds of young people followed this path to being arrested.

Dr. W. G. Anderson, who was King's classmate at Morehouse College, initiated the meeting of the Albany Movement and asked King to support the movement. At this juncture, and because of his close relationship with Anderson, King could not refuse to join the movement. ${ }^{951}$ However, the Albany Movement's mass movements, such as the jail-ins, kneel-ins, and sit-ins were practically led by the young people and college students of SNCC, and there were about two thousand activists who were jailed. The students of SNCC needed money to pay bails and fines; thus, they could not work without support from SCLC and Dr. Anderson. Even though SCLC promised to give "full moral and financial support to the Albany Movement," the media ignored the students' struggles and highlighted only the jailins of King and SCLC leaders. ${ }^{952}$ During the Albany Movement, SCLC's financial support for SNCC was managed by the executive director of SCLC, Wyatt Tee Walker. As an authoritarian pastor of the black Baptist church, Walker requested that SNCC staff submit detailed reports of how they used SCLC's funds. ${ }^{953}$ SNCC students began to be aggrieved at the attitude of Walker and at the media's biased highlighting of SCLC's leaders.

\footnotetext{
950 Ibid., 164.

951 Ibid., 167.

952 King, The Autobiography of Martin Luther King, Jr., 154; and Young, An Easy Burden, 174.

953 Ibid., 164.
} 
The Albany Movement's ambitious goal for targeting all desegregation without a well-organized strategy caused loose cooperation between the diverse civil rights organizations and local people. Andrew Young recognized the difficulties of the Albany Movement due to the internal conflicts between the young students and the hierarchical civil rights leaders and due to the weak strategy of the movement. ${ }^{954}$ Young tried to organize the citizenship workshops to develop strategies and tactics for the Albany Movement and to create a bridge between the hierarchical civil rights leaders and the young civil rights activists of SNCC. ${ }^{955}$ King found out that the Albany Movement had diverse age and career groups: "I shall never forget the experience of seeing women over seventy, teenagers, and middle-aged adults — some with professional degrees in medicine, law, and education, some simple housekeepers and laborers - crowding the cells."956 The various people and targets for desegregation could not be controlled by top-down orders, thus, the citizenship workshops could provide alternative opportunities to train and communicate with the young and diverse activists of Albany. Bernice Robinson trained and helped Charles Sherrod and Charley Jones set up the Citizenship School program in SNCC. ${ }^{957}$ After Sherrod and Jones joined the citizenship workshops of Robinson, and as the staff of the CEP did at the Dorchester Center, they trained Bernice Johnson, who was sixteen years old, to be a prominent activist of SNCC; she developed the activity of singing freedom songs in the Albany Movement. ${ }^{958}$

The local activists in Albany came to think that King's presence hindered their negotiation with city commissioners. ${ }^{959}$ While King and other affiliated leaders were in jail, the local activists tried to negotiate with the governor without consulting with the affiliated

\footnotetext{
954 Ibid., 170.

955 Ibid., 171.

956 King, The Autobiography, 155.

957 "Interview with Bernice Robinson," by Sue Thrasher and Elliot Wiggington, November 9, 1980, HFS Archives.

958 Young, An Easy Burden, 171.

959 Fairclough, To Redeem the Soul of America, 89.
} 
leaders. King insisted that the demonstrators should obey court orders without discussing this with the local activists. Because of this tactic, SNCC activists derided King as a "chicken, De Lawd." $" 960$ King tried to persuade the young activists of SNCC to keep the court orders when he summoned them to Anderson's home. Even though King discussed a long time with James Bevel, Diane Nash, Charles Sherrod, and Cordell Reagon that he did not want to lead the movement as he was used to doing, it was hard to repair the crack between the local leaders of Albany and King. ${ }^{961}$ The Albany city commissioner, Laurie Pritchett, who was the head of the police and a white supremacist, successfully harassed the jailed demonstrators and did not allow them to be bailed out, despite the jail being jampacked, and he oppressed King by pretending to negotiate while he himself played the media. With the negotiations with the city commissioners going roughly and without meaningful gains from the long demonstrations, King and Anderson made a decision to leave Albany, even though the local activists did not want to stop the movement. ${ }^{962}$

During the Albany Movement, the Citizenship School program had been growing Georgia, since the demonstration highlighted the importance of voter registration drives. James Bevel, who became known as a talented developer of the voting rights movement in Mississippi and who was the first full-time hired field activist of SCLC for the voting rights movement, was invited to develop the citizenship school program in Albany. ${ }^{963}$ Hosea Williams emerged as a prominent local leader through his successful voter registration drive of the Southeastern Georgia Crusade for Voters, which was an organizational extension of the local chapter of the NAACP in Savannah. ${ }^{964}$ When the NAACP refused to promote Williams, he was able to get support from the HFS and was finally hired by SCLC as a field staff

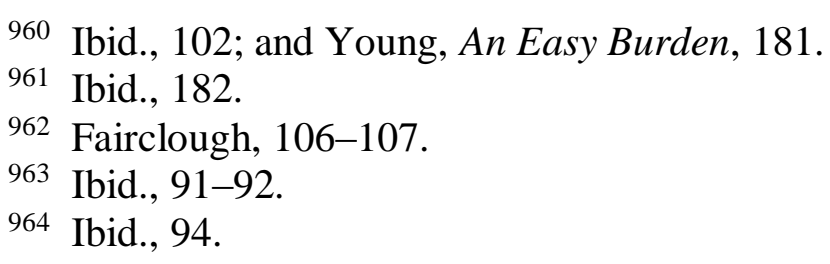


member in Georgia. Even though King confessed that SCLC had failed to gain a successful victory from the Albany Movement, the problems of the authoritarian leadership of SCLC could be altered with new leaders such as Bevel, Williams, and Young, who were trained as grassroots leaders for the voting rights movement. ${ }^{965}$ These young leaders were also the trainees of Septima Clark's Citizenship School and were all ministers who were familiar with training people for nonviolent resistance as a Christian discipline. They were all followers of the grassroots leadership of Clark and provided a new leadership model for the civil rights movement, which was Clark's model of training the grass roots and mobilizing them to fight for voting rights. Thus, Bevel, Williams, and Young were able to develop the Citizenship School's tradition into one that was based on Christian nonviolence and on proclaiming freedom through singing freedom songs like spirituals.

In May 1962, SCLC's board meeting made a decision to join the direct actions of Rev. Fred Shuttlesworth, who had initiated the Alabama Christian Movement for Human Rights (ACMHR) in Birmingham. Shuttlesworth had a ministry in Selma and moved to Birmingham in 1953 to pastor the Bethel Baptist Church. Because of his efforts for desegregation, Shuttlesworth was bombed while he was in his bed, and he was jailed the next day for sitting in a seat reserved for whites. He tried to register his daughter in the white-only high school to practice desegregation of the education system according to the Supreme Court's 1954 decision in Brown v. Board of Education, Topeka and was severely beaten. ${ }^{966}$ Shuttlesworth and the members of the ACMHR initiated strong social activities beginning in 1962, such as boycotts and sit-ins, which were highlighted by people across the South and by the media. In December 1962, every staff member of SCLC met for the staff retreat at the Dorchester Center. The retreat was a three-day meeting, and Young took on the role of

965 King, The Autobiography, 168.

966 Fairclough, To Redeem the Soul of America, 112. 
organizing the Birmingham Campaign as the director of the Dorchester Center. ${ }^{967}$ As Young had realized the needed role of the Citizenship School program in the Albany Movement, he insisted during the staff retreat that the Citizenship School program could be essential to training activists and communicating with the local leaders of Birmingham. ${ }^{968}$

The staff retreat at the Dorchester Center was for discussing the learning from the Albany Movement and for planning for the Birmingham Campaign with major supporters of SCLC. There were sessions for strategies in which Andrew Young, Dorothy Cotton, James Bevel, Martin King, Wyatt Tee Walker, and Fred Shuttlesworth led the debates for planning the campaign. ${ }^{969}$ Compared to the previous civil rights movements of SCLC, the staff retreat for the Birmingham Campaign was the turning point of SCLC's leadership. The Albany Movement was requested by the head of the movement who had a personal relationship with King, and SCLC staffers thought that SCLC wedged into the local movement without having a prepared strategy. However, SCLC's affiliation with the Birmingham Campaign was fully discussed with the whole staff of SCLC, and the staff had a retreat meeting to prepare for the campaign. During this meeting at the Dorchester Center, which was the headquarters of the CEP, the new leaders of the CEP, including Young, Bevel, and Cotton, were able to emerge and break through the hierarchical leadership structure and one-upmanship atmosphere of SCLC staff. ${ }^{970}$ As King described the process, "Because we [SCLC staff] were convinced of the significance of the job to be done in Birmingham, we decided that the most thorough planning and prayerful preparation must go into the effort." $" 971$

Clark's tactics of grassroots leadership changed the hierarchical leadership system of SCLC through the work of the grassroots leaders she had trained, such as Young, Bevel,

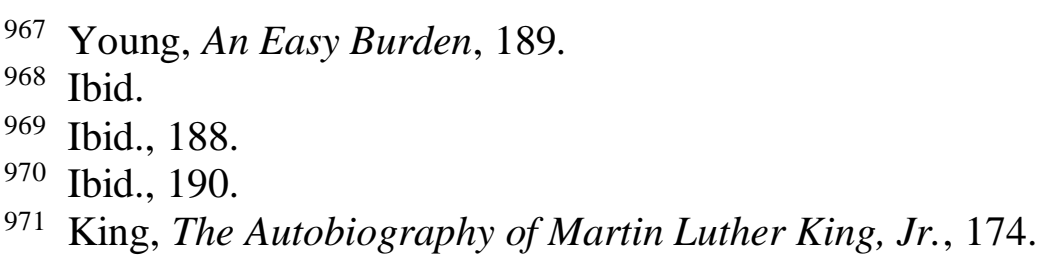


Cotton, and Williams. The staff retreat of SCLC at the Dorchester Center provided the new leaders of the CEP with occasions to join the decision making of SCLC, because the Dorchester Center gave them new opportunities to demonstrate how to train and maintain day-to-day contacts with local activists through the Citizenship School program. ${ }^{972}$ The essential role of Wyatt Tee Walker's executive director position, which involved maintaining King's relationship with the media and with SCLC's operation of business concerns, came to keep Walker from having a close relationship with local people. After the Albany Movement, as much as the need of working closely together with local activists increased, the role of Walker came to be reduced, and the role of the Citizenship School's trainers increased. This transition of SCLC's director's role impacted Young's taking Walker's position as the executive director of SCLC in 1964. Under this circumstance, Young emerged as the most important assistant among SCLC staff members, influencing King's decision making and the growth of SCLC with support from local activists, as Septima Clark witnessed. ${ }^{973}$

Through its workshops, the Citizenship School program became the crucial tactic for training and marshaling the activists of Birmingham, and it also enabled SCLC staff members to have close communication with the local activists. ${ }^{974}$ The Citizenship School program trained its students using "four steps: investigation, communication/negotiation, confrontation, and reconciliation." 975 SCLC people tried to investigate the social problems in Birmingham through discussions with Shuttlesworth, and they made a decision to focus their concerns on achieving economic rights by boycotting white racists' businesses and challenging politicians to act. Targeting the Easter season, which was usually the bestselling period of merchants for new clothes and presents during the first half of the year, SCLC and

\footnotetext{
972 Young, An Easy Burden, 189.

973 See page 201.

974 Young, An Easy Burden, 189.

975 Ibid., 189-190.
} 
local activists in Birmingham boycotted white stores at a citywide level that refused to hire black employees. For negotiation, Young tried to have close relationships with the local community and the ACMHR and to use his connections in Birmingham through his previous relationship with the National Council of Churches. Through these relationships, the activists in Birmingham were able to have frequent contacts with the white leaders of businesses and to negotiate with each other. ${ }^{976}$

For practicing confrontation and reconciliation, the CEP's nonviolent workshop was held for a month at the Dorchester Center to train the activists of the Birmingham Campaign. Along with the workshop for voting rights, this workshop invited Bevel, Nash, and Lawson to maintain the workshop at Dorchester Center for nonviolent tactics. ${ }^{977}$ The leadership of the Birmingham Campaign, which was constituted by the board members of the ACMHR and SCLC, initiated "Project C," with the "C" standing for "Birmingham's Confrontation with the fight for justice and morality in race relations." 978 The goal of the Birmingham Campaign was not only desegregating the complicated social system of Birmingham, but also challenging the Kennedy administration to propose the civil rights bill with the full support of African Americans in the Southern states. ${ }^{979}$

Continuing the boycott of the stores in the downtown area through the mass movement of Miles College's students in January 1962, the ACMHR and SCLC led sit-ins, boycotts, and marches on Birmingham City Hall and jail-ins and kneel-ins to target these goals: desegregation of the stores and the public school system, equal opportunities for employment in stores and public offices, the reopening and desegregation of the city's

\footnotetext{
976 Ibid., 190.

977 Ibid., 192.

978 King, The Autobiography of Martin Luther King, Jr., 174; and Wyatt Tee Walker suggested "Project C." See Branch, Parting the Waters, 690. 979 Young, An Easy Burden, 193.
} 
recreation parks, and the establishment of a committee on biracial biases. ${ }^{980}$ The Birmingham Campaign was demanding on SCLC because they had to recruit demonstrators and alleviate the complaints about Shuttlesworth's autocratic leadership in previous demonstrations. ${ }^{981}$ Even though hundreds of demonstrators were jailed because of the campaign and the media highlighted the mass movements in Birmingham, there were still bystanders among large groups of professional African Americans and elite clergy who had apathetic attitudes toward Shuttlesworth and feared the brutal oppression of the city commissioner, Eugene "Bull" Connor. ${ }^{982}$ As King describes this obstacle to overcome in his "Letter from Birmingham Jail," he strongly appeals to the elite clergy who criticized the campaign as being the activities of extremists and "outside agitators."

Clark's grassroots leadership was highlighted through the children's march on Kelly Ingram Park, which led to the success of the Birmingham Campaign, and its success enabled the March on Washington and the Selma to Montgomery marches. Clark's training and mobilizing tactics of the Citizenship School were applied exactly to the children's march at the Birmingham Campaign. Bevel, Clark, Cotton, Nash, and Young, the CEP staffers who set up and maintained the CEP workshops in Birmingham, persuaded King and SCLC staff to allow the participation of young students and children in the demonstrations. ${ }^{984}$ Setting up the CEP workshops for nonviolence and voting rights in Birmingham, Bevel, Clark, Nash, Cotton, and Forman from SNCC began to train ten or fifteen teenagers in the basement of the Sixteenth Street Baptist Church. ${ }^{985}$ The number of young activists in the CEP workshops mushroomed, and hundreds of teenage demonstrators were trained in the detailed tactics of

\footnotetext{
980 Garrow, Bearing the Cross, 237.

981 Ibid., 238.

982 Ibid., 239.

983 King, The Autobiography, 196-197.

984 Fairclough, To Redeem the Soul of America, 124.

985 Cotton, If Your Back's not Bent, 212.
} 
nonviolence. The Birmingham Campaign was transformed into a vibrant movement of young students. There is a report concerning this change:

The demonstrations were begun by Negro adults in early April but they were soon taken over by young people. It became their demonstration. Most of them were high school students - although there were some elementary school children and a few college students - mainly from middle-class families. . . Before any students demonstrated, they were trained in the non-violent technique by Rev. Martin Luther King and his aides. ${ }^{986}$

This description demonstrates how the leadership of the civil rights movement shifted to grassroots leadership, which was filled by the determined spirit of the grassroots leaders. Just as Clark wanted to train grassroots people to be leaders who were able to be subjects of the movement, not the followers of one top leader, the multiple young grassroots leaders, who had their own determined spirit of fighting for human rights, emerged during the Birmingham Campaign.

The teenage demonstrators of the Birmingham Campaign were fully armed in the strong tactics of the CEP workshops. Some of them bravely said to adults, "We went to jail for you; now you register to vote for us." 987 Young asserted that the young student demonstrators were not the scratch team for the campaign:

The Sixteenth Street Baptist Church was crowded at 8:00 A.M. Instead of going to school that Thursday, youth decided to come to church. . . These youth come to us only with a willingness to stand together in the face of possible suffering, we teach them what we can, and God does the rest. The result is almost miraculous. The training deals with the background of the non-violent movement in the New Testament teaching, "love your enemies, bless those that persecute you"; and the practical applications of this spirit which have been made by Gandhi in India, and by Thoreau and Martin Luther King in the U.S. ${ }^{988}$

On May 7, 1963, with the main shaft of the young students coming from the CEP workshops, thousands of young people nonviolently marched on Kelly Ingram Park, using the tactics they

\footnotetext{
986 K. Lenihan, "Report on Birmingham, Alabama," 1963, KPKC, 134:23.

987 "Report to the VEP," September 1963, KPKC, 138:22.

988 Andrew J. Young, "Teens on the March in Birmingham," Friends, February 9, 1964, KPKC, 135:26.
} 
had learned from the workshops. As in the tradition of the HFS, these young students, some of them just nine or ten years old, sang freedom songs without fear of Bull Connor's brutal order of suppression nor when the police officers attacked them with firehoses and police dogs. ${ }^{989}$ The police brutality against the young student demonstrators was reported worldwide and challenged the Birmingham business elites who had been bystanders, such as A. G. Gaston, who supported SCLC by providing free rent for his motel rooms and who owned part of Kelly Ingram Park, to begin to find a way to negotiate with business leaders. ${ }^{990}$

Based on his connections with the people of the Episcopal churches in Birmingham, Young joined the meetings for negotiating with the business leaders of Birmingham. ${ }^{991}$ The key members of the meetings were King, Shuttlesworth, Young, Gaston, and Sydney Smyer, who was one of the business leaders. The scene of the police brutality on Kelly Ingram Park played a critical role in achieving a victory from the Birmingham Campaign. The merchants and city officers were challenged by the worldwide discredit to the image of Birmingham after the brutal attacks against young students. Finally, King, Walker, Shuttlesworth, Young, the Senior Citizens Committee of Birmingham, and eighty-nine of Birmingham's business leaders agreed to hire black clerks in the stores, desegregate educational systems and public facilities, hire black people as police officers, and establish a Committee on Racial Problems and Employment with a biracial membership. ${ }^{992}$ The Supreme Court of Alabama ruled against the tenure of Connor. ${ }^{993}$ Moreover, President Kennedy arranged a new conference for announcing the Birmingham settlement on May 8, 1963, and he proposed the civil rights bill to Congress on June 11, 1963.

\footnotetext{
989 Ibid.

990 Garrow, Bearing the Cross, 249; and Marie A. Sutton, A. G. Gaston Motel in Birmingham: A Civil Rights Landmark (Charleston: The History Press, 2014), 116.

991 Young, An Easy Burden, 203.

992 Garrow, Bearing the Cross, 259.

993 Jackson, From the Civil Rights to Human Rights, 163. 
From the initial staff meeting for setting the tactics of the Birmingham Campaign to the young students' march on Kelly Ingram Park, the CEP workshops, which were based on the church community in Birmingham, and its staffers crucially contributed to the success of the campaign. Clark witnessed that the young students of the march came down to Selma to help with the CEP's voter registration drives. ${ }^{994}$ Young played the roles of teaching nonviolence in the CEP workshops and negotiating between the activists of the campaign and the business leaders of Birmingham. Through the success of the Birmingham Campaign, SCLC and King could demonstrate the power of nonviolent movements worldwide and retrieve their reputation for leading the civil rights movement. This success paved the way for SCLC's preparation for the nationwide movement of the March on Washington for Jobs and Freedom. The success of the campaign inspired other civil rights organizations to establish biracial city committees in other Southern cities. Medgar Evers, who was trained by Bernice Robinson in how to establish Citizenship School programs and who worked on voter registration drives as the field secretary of the NAACP, was murdered while trying to establish a biracial committee in Mississippi after the success of the Birmingham Campaign. ${ }^{995}$ Shuttlesworth was willing to help with the Selma to Montgomery marches because he could promote the relationship with SCLC and King through the campaign. Young demonstrated his ability to negotiate and strategize during the Birmingham Campaign and emerged as the new executive director of SCLC and as King's closest assistant. ${ }^{996}$

These results of the Birmingham Campaign were essentially based on the efforts of the trainees of Clark's Citizenship School. During the Birmingham Campaign, Clark taught young students in the Birmingham Campaign and consulted with the voting rights activists in

994 Clark, Ready from Within, 72.

995 Young, An Easy Burden, 252.

996 Ibid., 235; and Dyson, I May Not Get There with You, 90. 
Selma and the many cities in Georgia and Mississippi. ${ }^{997}$ In line with these voting rights efforts of Clark, the Selma to Montgomery marches and the Freedom Summer Project were prepared during the Birmingham Campaign. ${ }^{998}$ Clark continued to operate the citizenship workshops at the Dorchester Center and to help and train local people in Southern communities to set up Citizenship School programs through the time of the Selma to Montgomery marches. ${ }^{999}$ She trained local people to be leaders like her. When they went back to their communities, the trainees of Clark's workshops mobilized their community people to be leaders for the voting rights movements, such as the Birmingham Campaign and the Selma to Montgomery marches. ${ }^{1000}$ SCLC staffers Cotton, Ponder, Bevel, Young, and Williams; SNCC staffers Fannie Lou Hamer, Bob Moses, and James Forman; the NAACP staffer Medgar Evers; and CORE staffer Michael Schwerner set up citizenship schools during this period, when they came back to their organizations in local areas after they had attended Clark's workshops. ${ }^{1001}$

These young grassroots leaders who were trained by Clark's workshops were armed with the determined spirit of fighting for human rights. Concerning the grassroots leadership, Clark insisted, "Voluntary participation can only be achieved through motivation."1002 The Citizenship School programs focused on promoting the motivation of grassroots people by developing their self-awareness. As she taught the young students during the Birmingham Campaign, and according to her strong Christian faith, Clark highlighted that the goal of the voting rights movement was fostering and creating an ontological community: "The 'beloved community' in which all children of God live together as brothers will not be, South or North,

997 Clark, Ready from Within, 72-73.

998 See Ibid., 26, 35.

999 Ibid., 64-68.

1000 Ibid., 64.

1001 Ibid., 60-72.

1002 Clark, Echo in My Soul, 238. 
East or West, the unusual community." 1003 As the grassroots leaders of the Birmingham Campaign and the Selma to Montgomery marches did, Clark trained grassroots people to be community leaders who returned to their communities "to find and train other leaders in techniques that bring success." 1004 The success that the grassroots leaders created was to mobilize local people to make efforts to promote voter registration and to participate in political campaigns such as the Birmingham Campaign and the Selma to Montgomery marches. ${ }^{1005}$ This essential technique of training and mobilizing grassroots leaders was taught by Clark's Citizenship School programs and led the voting rights movement to be successful. Just as she used the Christian concept of nonviolent resistance to convert white racists according to her AME Church tradition, Clark encouraged her trainees, saying, "But it [nonviolent tactic] seeks to accomplish victory not by humiliating its opponent but instead by winning him, by converting him from an enemy into a friend." ${ }^{1006}$ Clark's nonviolent tactic was successfully practiced in the voting rights movement from the Birmingham Campaign to the Selma to Montgomery marches.

\section{The March on Washington for Jobs and Freedom and the Citizenship School}

The strong enthusiasm for freedom in the Birmingham Campaign and the martyrdom of Medgar Evers escalated the nationwide need for revolution to abolish the American social system of segregation. ${ }^{1007}$ According to King, the nationwide program to proclaim the social revolution in racial segregation, the March on Washington, was proposed by A. Philip Randolph, who was a longtime leader of the labor movement as the president of the Brotherhood of Sleeping Car Porters. ${ }^{1008}$ In 1941, Randolph initiated the March on

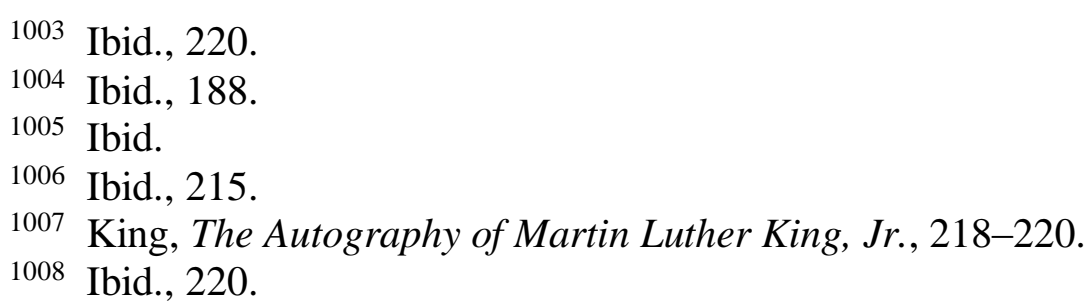


Washington Movement (MOWM) to expose racial discrimination in labor environments. ${ }^{1009}$ He believed that freedom should be guaranteed through job opportunities that provide families with sufficient food, clothing, and housing. ${ }^{1010}$ Through this march of grassroots people, Randolph demanded an "Eight Point Program," which included abolishing any segregation laws, enforcing the laws that guaranteed job opportunities and training for any person, ensuring equal voting rights and equality in hiring, and establishing representation for African Americans and minority people. ${ }^{1011}$ With help from Bayard Rustin, the NAACP, and the National Urban League (NUL), the MOWM was able to organize about 100,000 marchers. ${ }^{1012}$ Even though Randolph's Eight Point Program was not fulfilled, President Franklin D. Roosevelt established the federal agency called the Fair Employment Committee. ${ }^{1013}$ During the 1950 s, Randolph also organized three marches on Washington. ${ }^{1014}$ In 1962, before the Birmingham Campaign, Randolph had already discussed with Rustin a plan to march on Washington to demand the economic advancement of African Americans. ${ }^{1015}$

According to CEP staffers, it was Bevel who first suggested the nationwide march in 1963. ${ }^{1016}$ Cotton and Young asserted that Bevel, who was the key organizer of the young students' march on Kelly Ingram Park in Birmingham, suggested the march to Washington from Birmingham. ${ }^{1017}$ Based on his success in Birmingham, Bevel assured SCLC staff that he could train over eight thousand young students to march to Washington from Birmingham

1009 A. Philip Randolph, For Jobs and Freedom: Selected Speech and Writings, ed. Andrew E. Kersten and David Lucander (Amherst: University of Massachusetts Press, 2014), 199.

1010 Ibid., 209.

1011 Ibid.

1012 Ibid., 15.

1013 Ibid.

1014 Ibid., 238.

1015 Daniel Levine, Bayard Rustin and the Civil Rights Movement (New Brunswick: Rutgers University Press, 2000), 131.

1016 Young, An Easy Burden, 269.

1017 Ibid; and Cotton, If Your Back's Not Bent, 218. 
along Highway 11, just as Gandhi did with his Salt March to the Sea. ${ }^{1018}$ He envisioned a dramatic march of grassroots people who were willing to go to jail during the march. ${ }^{1019}$ SCLC administration would not accept Bevel's idea because it was too dangerous for thousands of young children to walk over twelve hundred miles. ${ }^{1020}$ However, Young had a discussion with Bayard Rustin and A. Philip Randolph about realizing Bevel's idea for a dramatic march of the grass roots as an appeal for the civil rights of African Americans. ${ }^{1021}$ Young enthusiastically promoted this march because he remembered that SCLC's Prayer Pilgrimage to Washington in 1957 influenced President Dwight D. Eisenhower to sign the Civil Rights Act of 1957, which established the Commission on Civil Rights and the Civil Rights Division of the US Justice Department. ${ }^{1022}$

On July 2, 1963, Martin King, James Farmer of CORE, John Lewis, A. Philip Randolph, Roy Wilkins of the NAACP, and Whitney Young of the NUL had a meeting for organizing a march on Washington. ${ }^{1023}$ They agreed to schedule the march for the end of August and to call it the "March for Jobs and Freedom." 1024 Officially, the leadership of the march agreed on Randolph as the director and Rustin as the "deputy director."1025 The leaders of the March on Washington opened it up to the white liberals and the middle-class African Americans who joined the march by riding forms of public transportation. Bevel was angered by this decision because he originally proposed a revolutionary children's march of people who did not care about being jailed, not a march like a picnic. ${ }^{1026}$ Young personally made a decision not to participate in the march; however, King urged Bevel and Young to

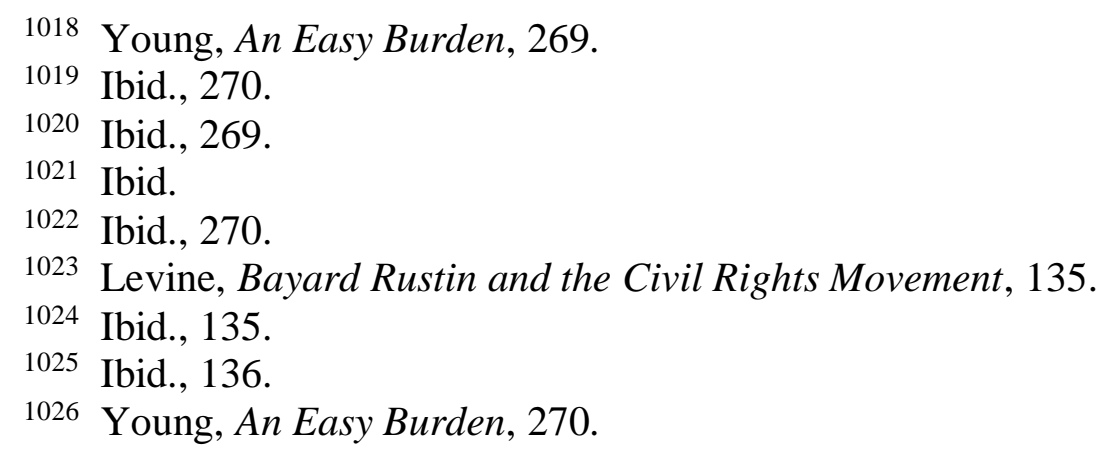


join it. ${ }^{1027}$ Even though there were arguments concerning King's moderate demands of the march, which he thought should embrace diverse civil rights organizations and groups of people on a national level, King made the goal of the march clear: "to arouse the conscience of the nation over the economic plight of the Negro."1028

As Randolph wished, the March on Washington for Jobs and Freedom was supported by civil rights organizations nationwide, such as CORE, the NAACP, the Negro American Labor Council (NALC), the NUL, SCLC, SNCC, and white social groups, such as the United Auto Workers (UAW), the National Catholic Conference for Interracial Justice, the United Presbyterian Church, and the American Jewish Congress. ${ }^{1029}$ This march targeted not only pushing the US Congress to pass the civil rights bill but also dramatizing the joblessness, poverty, and poor education and housing of African Americans. ${ }^{1030}$ The American Federation of Labor and Congress of Industrial Organizations (AFL-CIO), which was one of the largest labor unions, refused to support the march because it had an uncomfortable relationship with the leader of the UAW and because increasing African American employment might damage its seniority system. ${ }^{1031}$ King expressed his disappointment at the AFL-CIO's decision to keep a neutral position toward the march, calling it an "unhappy contrast." 1032 On August 28, 1963, the marchers, who came from every part of the nation and were estimated to number from 200,000 to 500,000, gathered at the Washington Monument and marched to the Lincoln Memorial. ${ }^{1033}$ The speeches and performances on the stage of the

\footnotetext{
1027 Ibid., 271.

1028 Garrow, Bearing the Cross, 278.

1029 Jackson, From Civil Rights to Human Rights, 175-176.

1030 Ibid., 177.

1031 Ibid., 178; and Garrow, Bearing the Cross, 280.

1032 King, The Autobiography of Martin Luther King, Jr., 222.

1033 Taylor Branch, The King Years: Historic Moments in the Civil Rights Movement (New York: Simon \& Schuster, 2013), 62-63.
} 
march were broadcast to people nationwide, including President Kennedy, by the Columbia Broadcasting Services (CBS). ${ }^{1034}$

King's "I Have a Dream" speech was the climax of the march. However, the leaders of the march ignored the requests of women leaders to speak, such as Septima Clark of the CEP, Dorothy Height of the YWCA, Anna Arnold Hedgeman of the National Council of Churches, and Pauli Murray of the Presidential Commission on the Status of Women. ${ }^{1035}$ Height was angered by the sexism of the leaders of the march, who had arranged for the only woman's voice to come from the podium-Mahalia Jackson's. Jackson had the only major program led by a woman, and she led the closing songs. ${ }^{1036}$ This ignorance regarding women civil rights leaders at the stage of the march awakened women leaders to set forward a women's movement for fighting against sexism in the civil rights movement. ${ }^{1037}$ Murray wanted to fight against "Jane Crow," a term which referred to the way in which sexists' traditions discriminated against women the same way the Jim Crow laws did against black people. ${ }^{1038}$ Through the complaints of women civil rights leaders, the leadership of the march suddenly added the program "Tribute to Negro Women Fighters for Freedom."1039 For the program, Mrs. Myrlie Evers, the wife of Medgar Evers, was scheduled to give words honoring women civil rights leaders, including herself, Daisy Bates, Diane Nash, Mrs. Herbert Lee, Rosa Parks, and Gloria Richardson. ${ }^{1040}$ Murray criticized this secondary program for women civil rights leaders as a "bitterly humiliating" program for women. ${ }^{1041}$

\footnotetext{
1034 Jackson, From Civil Rights, 179.

1035 Ibid., 181-182.

1036 Height, Open Wide the Freedom Gates, 145.

1037 Ibid.

1038 Collier-Thomas, Jesus, Jobs, and Justice, 458.

1039 "March on Washington for Jobs and Freedom," Lincoln Memorial program, Civil Rights Movement Veterans, http://www.crmvet.org/docs/mowprog.pdf.

${ }_{1040}$ Ibid. Mrs. Evers could not be on the stage of the march, thus Daisy Bates was substituted in her place.

1041 Collier-Thomas, Jesus, 458.
} 
The CEP played a role in encouraging people to participate in the March on the Washington for Jobs and Freedom. The CEP staffers contacted a thousand people to invite them to march to proclaim that they are "owners of government," as they had learned from the CEP workshops. ${ }^{1042}$ Cotton helped King type his "I Have a Dream" speech. According to Cotton, King's closing phrases of the speech were not included in the manuscript; King extemporaneously added them at the podium. ${ }^{1043}$ King witnessed that he had used the "I have a dream" phrase many times before the march. ${ }^{1044}$ Cotton remembered that she introduced King to the speech of a white female student from Vassar College given at a local church when King was absent from the place. The college girl shared her vision, using the "I have a dream" phrase as a refrain, with African American attendees. ${ }^{1045}$ Cotton believed that the white college girl's speech inspired King to make his "I Have a Dream" speech. ${ }^{1046}$ Another possible inspiration for King's "I have a dream” refrain was Prathia Hall's prayer. Hall was working for the voting rights movement as a field worker of SNCC. When she prayed with the staffers of SNCC and SCLC, including King, at the site of the burned church, Hall repeated the phrase "I have a dream."1047 Even though these two possibilities were not verified by King, they were closely interrelated to grassroots civil rights leaders for the voting rights movement.

Clark recognized the March on Washington for Jobs and Freedom as an event reminiscent of the Prayer Pilgrimage to Washington in 1957. ${ }^{1048}$ She witnessed that the Prayer Pilgrimage to Washington was organized by women. ${ }^{1049}$ As Clark remembered, this

\footnotetext{
1042 Cotton, If Your Back's Not Bent, 221.

1043 Ibid., 222.

1044 King, The Autobiography of Martin Luther King, Jr., 223.

1045 Cotton, If Your Back's Not Bent, 219-220.

1046 Ibid., 221; and see Appendix F, "Interview with Dorothy Cotton."

1047 Holsaert et al., eds., Hands on the Freedom Plow, 180.

1048 Clark, Ready from Within, 83.

1049 Ibid.
} 
mass movement had been the largest march of the civil rights movement, with 25,000 participants, before the March on Washington for Jobs and Freedom. King and Randolph had agreed with holding the Prayer Pilgrimage to Washington in association with the NAACP, SCLC, the Brotherhood Sleeping Car Porters, the MIA, and several black churches and labor unions. Bayard Rustin and Ella Baker had organized this event. ${ }^{1050}$

The success of the March on Washington for Jobs and Freedom crucially contributed to accelerating the civil rights bills' passage by the United States government in 1964 and 1965. Even though the initial proposal of Bevel for the grassroots march was attenuated, the moderate march opened up people of all races to participate in the social struggles of African Americans at the national level. The media biasedly highlighted King's speech, ignoring the economic demands of the march. However, President Kennedy was surprised by the success of the march, and the international interest in African Americans' struggles for freedom elevated the status of African Americans. ${ }^{1051}$ The march expanded the geography of the civil rights movement, as Young witnessed: "We suddenly realized that this [the march] turned us from a Southern black movement into a national multiracial human rights, an international multiracial human rights movement." 1052 Even though it was an added program, honoring Medgar Evers through his wife's presence on the stage of the march demonstrates Evers's contribution to gathering people nationwide to remember his sacrifice. Bernice Robinson trained Evers as the field secretary for the voting rights movement of the NAACP. ${ }^{1053}$ The

\footnotetext{
1050 Levine, Bayard Rustin and the Civil Rights Movement, 99.

1051 Stephen B. Oates, Let the Trumpet Sound: The Life of Martin Luther King, Jr. (New York: Harper \& Row, 1982), 262; and Lewis V. Baldwin, Never to Leave Us Alone: The Prayer Life of Martin Luther King, Jr. (Minneapolis: Fortress Press, 2010), 79. 1052 Michael Fletcher, "An Oral History of the March on Washington," Smithsonian Magazine, July 2013, https://www.smithsonianmag.com/history/oral-history-march-washington-180953863/. 1053 See page 140.
} 
contributions of the CEP's trainees, such as Bevel, Cotton, Young, and Evers, played key roles in the success of the March on Washington for Jobs and Freedom.

\section{The Freedom Summer of COFO}

In the summer of 1961, SNCC staffers gathered at the HFS to plan the next steps following the Freedom Rides. Bob Moses was trying to set up citizenship schools in McComb, Mississippi, with two SNCC people, Reggie Robinson and John Hardy. ${ }^{1054}$ During this period, under Clark's supervision, Bernice Robinson trained almost all of the voting rights leaders of SNCC, CORE, SCLC, and the NAACP. At Moses's request, Robinson helped SNCC and CORE people set up the Citizenship School programs in Mississippi, Alabama, and Georgia. Robinson taught them all the tactics of the citizenship education programs: "how to get people together, how to get voter turnout, how to get money to finance schooling - all that." 1055 The staffers of SNCC argued about whether they should focus on initiating the voting rights movement or on maintaining dramatic direct actions, such as sitins and boycotts for desegregating public facilities. ${ }^{1056}$ The Taconic and Field Foundations, which supported primarily the educational programs of the civil rights organizations, tried to sound SNCC out about the organization's future directions for the civil rights movement, and Robert Kennedy suggested that they have a cooling-off period after the Freedom Rides. ${ }^{1057}$ During the meeting at the Dorchester Center, SNCC staffers made a decision to have two wings as SNCC's major tactics: direct action and the voting rights movement. ${ }^{1058}$ Even though Diane Nash took charge of leading direct actions as a result of this meeting, she helped SNCC set up voter registration drives. Nash asked her friend James Forman, who was

1054 Zinn, SNCC: The New Abolitionist, 58.

1055 "Interview with Bernice Robinson," by Eugene Walker, HFS Archives.

1056 Ibid.

1057 Ibid., 58-59.

1058 Ibid., 59. 
an educator and writer in Chicago, to come join SNCC's staff. ${ }^{1059}$ Nash invited him to be an executive secretary because she felt that SNCC needed a staffer who could train young people and publicize their activities. ${ }^{1060}$ Nash's invitation to Forman shows that SNCC tried to reform its tactics, which had been focused too much on direct actions to endeavor to train civil rights activists.

Like the Field Foundation grants supported the independent activities of SCLC, the grants of the Taconic and Field Foundations influenced SNCC's civil rights activities to become specialized in the voting rights movement. The consultants of Clark and Robinson originated this change in SNCC's civil rights activities. As a trainee of Clark's workshop, Forman reformed the structure and fund-raising system of SNCC as a skillful organizer, just as Young did with SCLC. He organized 180 full-time activists of SNCC from 1961 to 1963. ${ }^{1061}$ Charles Cobb, who was a son of a Congregational church's pastor in Massachusetts, a student of Howard University, and a trainee of Clark's workshop, took charge of the voting rights movement of SNCC. Bob Moses, who was Harlem-bred and graduated from Harvard University, operated the citizenship workshops as he had learned from Bernice Robinson. ${ }^{1062}$ White racists strongly resisted SNCC's voting rights workshops from their beginning. In August 1961, Billy Jack Caston, who was a relative of a sheriff, hit Moses's head with a knife while Moses was helping people register to vote. Moses received nine stitches due to the injury. ${ }^{1063}$ Herbert Lee, who was a farmer who gave rides to SNCC people so they could register to vote, was shot to death. Travis Britt and John Hardy, who were SNCC co-workers for voter registration along with Moses, were beaten by local racists. SNCC workers for voting rights found out that operating voter registration workshops in

\footnotetext{
1059 Ibid., 60.

1060 Michael V. Uschan, James Forman and SNCC (Detroit: Lucent Books, 2013), 40.

1061 Ibid., 42.

1062 "Interview with Bernice Robinson," by Walker.

1063 Uschan, James Forman and SNCC, 49.
} 
Mississippi was more dangerous than sit-ins and Freedom Rides. ${ }^{1064}$ As they had learned from Clark's organizing technique for local people, Bevel, Forman, Moses, and other SNCC staffers would travel to cities in Mississippi to recruit people to register to vote. Forman sent Sherrod, Reagon, and Jones to set up voter registration drives in Albany during the Albany Movement. ${ }^{1065}$ Even though the Albany Movement had decreased in force, the voter registration drives of SNCC successfully awakened black people to register; in one district as many as ninety percent of black voters were registered and voted. ${ }^{1066}$

With the help of Tom Gaither of CORE, Moses initiated COFO, which unified into one organization the voting rights movements of CORE, SCLC, SNCC, and the NAACP in 1962. ${ }^{1067}$ COFO could be supported by the Taconic and Field Foundations through the Voter Education Project (VEP) of the Southern Regional Council (SRC). ${ }^{1068}$ COFO was initiated to develop the statewide student movement and to operate the summer program in Mississippi. ${ }^{1069}$ The summer program of COFO invited college students and educators in the North to teach tenth and eleventh graders to develop their self-awareness and to learn ways of resisting against segregation. ${ }^{1070}$ COFO called the summer program "Freedom Schools"; these schools taught their students basic grammar, math, writing, reading, history, music, drama, political science, and social studies. ${ }^{1071}$ COFO planned to establish twenty-five Freedom Schools in twenty to twenty-five towns with black communities. ${ }^{1072}$ The Freedom Schools also trained young students to have experience as field workers in voter registration.

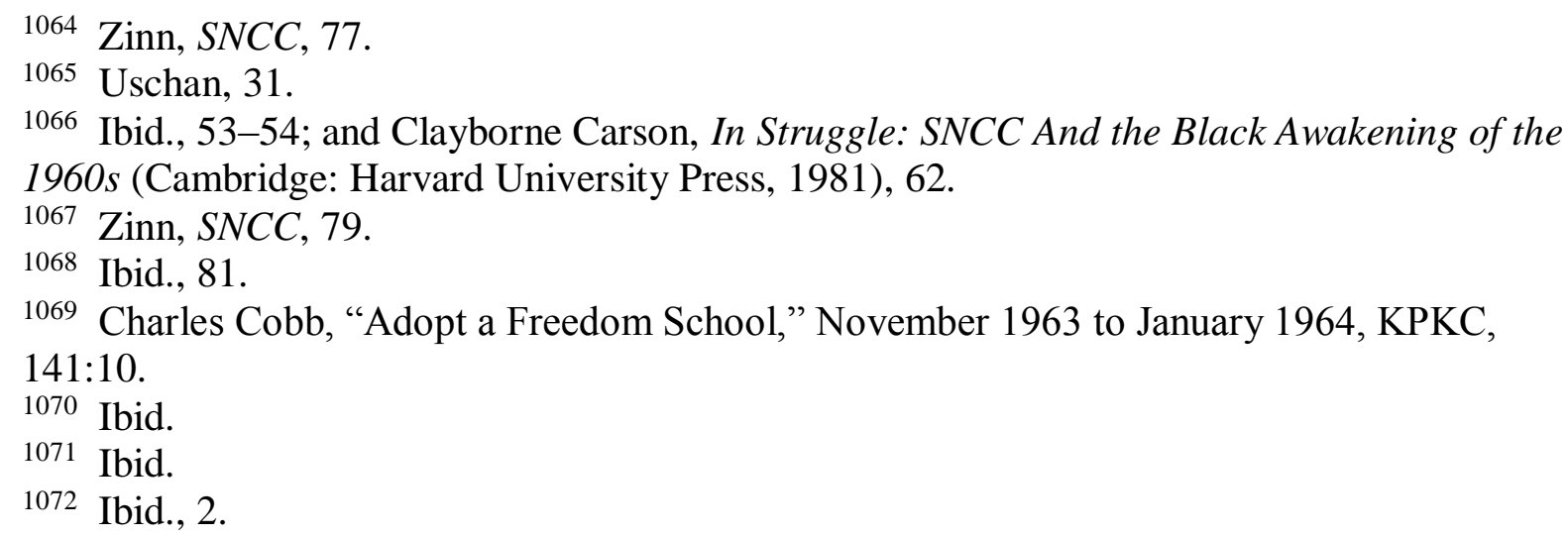


After the Freedom Schools, the students of the schools were recruited and connected to established organizations of ministers, activists, and educators in their communities. ${ }^{1073}$

Moses sent his staffers to the HFS workshop to learn the techniques of operating workshops for voting rights as he had learned them from Robinson. ${ }^{1074}$ From the training at the HFS, Moses encouraged Sam Block and Willie Peacock to establish the voting rights workshop in Greenwood, Mississippi. The VEP funds allowed COFO to hire more full-time and part-time field workers to expand the voter registration drives in Mississippi and Alabama. Even though the harsh attacks on the voter registration drives in Mississippi interrupted the growth of COFO's movement, COFO staffers went there to distribute food to about 5,000 families, which consisted of up to 22,000 people. ${ }^{1075}$ Aaron Henry, who was the president of COFO as the state president of the NAACP Mississippi branch, raised funds from Mrs. Vera Pegues, a beautician in Clarksdale, to supply food for the needy in LeFlore and Madison Counties. ${ }^{1076}$ The donations for food supplies were increased by supporters from cities around the country, including Iowa City, Louisville, Los Angeles, Lansing, Ann Arbor, and Detroit. ${ }^{1077}$ COFO's work to supply food could break through the unwillingness of black people to register to vote because COFO staffers could explain that the people who needed food also needed freedom through voting. Moses believed that COFO had an opportunity to persuade people to vote through providing food donations. ${ }^{1078}$

As many students from the sit-ins joined the workshops of the HFS, Forman encouraged his staffers to attend the voter registration workshop of the HFS in 1962. The HFS workshop moved to Knoxville after the state of Tennessee padlocked the HFS's original

1073 Ibid., 5.

1074 Carson, In Struggle, 77.

1075 Larry Still, "Economic Pressure Against 5,000 Families Affects 22,000 People," Jet Magazine, Feb. 21, 1963.

1076 Ibid.

1077 Ibid.

1078 Carson, In Struggle, 80. 
building in New Market. After COFO staffers were trained by Robinson's HFS workshops, Forman and Moses asked Robinson to set up citizenship schools in Mississippi during the summer of 1962. ${ }^{1079}$ Robinson organized voter education workshops in Jackson, Edwards, Mississippi City, Greenwood, and Ruleville; she also organized workshops in Baton Rouge, Louisiana, as CORE had requested. HFS staffers worked with Moses and COFO people to conduct the long-range programs of the voter education workshops. ${ }^{1080}$ During the voter registration efforts of COFO, Medgar Evers was murdered and the Winona jailers abused Fannie Lou Hamer and five other workshop leaders. Esau Jenkins also assisted with the workshops of COFO as a consultant, and HFS staffers helped COFO establish the voter education workshops in Selma, Alabama. ${ }^{1081}$ Based on this support from the HFS, COFO held the first workshop for planning the Freedom Summer Project in November 1963 under the supervision of Myles Horton. ${ }^{1082}$

At this COFO workshop, John Lewis (who was the chairman of SNCC), James Forman, and other SNCC staffers made a decision to conduct hundreds of new workshops for the Mississippi Freedom Summer Project, which focused on four major fields: "Freedom Schools, community centers, a voter registration campaign, special projects."1083 At the executive committee meeting of SNCC, Moses proposed inviting thousands of biracial students to join the Mississippi Summer Project. Even though SNCC staffers expressed concern that Moses's invitation to white students would exacerbate the racial problems in SNCC, Moses's proposal to train local people to develop statewide voter registration drives was adopted. ${ }^{1084}$ Along with the VEP funds for COFO, the Freedom Summer Project could

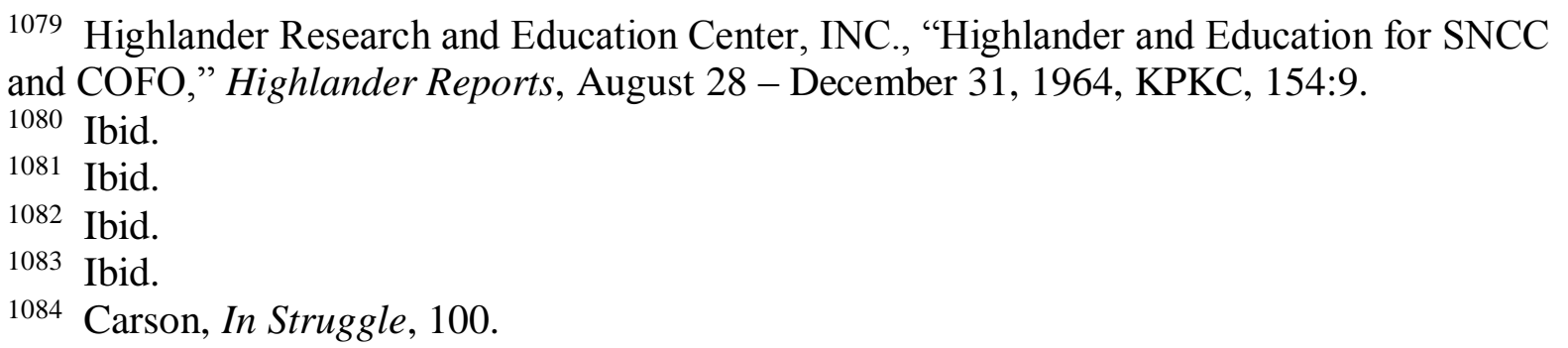


be supported by the National Council of Churches and the Medical Committee for Human Rights. With an increase in the risk of violence as the voter registration drives grew, Moses realized that a political organization was needed to be responsible for protecting the people who wanted to practice their political needs. ${ }^{1085}$ Moses's proposal to establish a political organization was accepted at the COFO administration's meeting and by Northern supporters. Thus, with the help of Ella Baker, the Mississippi Freedom Democratic Party (MFDP) was founded on April 26, 1964. ${ }^{1086}$ The MFDP elected eight candidates, including Victoria Gray and Fannie Lou Hamer, for the Democratic convention.

To assist with the Freedom Summer Project, the HFS took charge of training white students who were invited to help with the project. ${ }^{1087}$ This project of the HFS was called the "White Community Project," and it educated the poor and uneducated white people in Mississippi. ${ }^{1088}$ This project was part of the special project field of the Freedom Summer Project. The special projects included a research project, which involved researching the political and economic life in Mississippi to capture the social situation. Through the research project, the Freedom Summer Project could gain accurate information by which it could change the social structure of Mississippi using voter registration drives and the political activities of the MFDP. ${ }^{1089}$ Another special project was the "Law Student Project."1090 COFO invited a large number of students who had majored in law to operate the Freedom Summer Project. The law students challenged officials who imposed tyranny on innocent

\footnotetext{
1085 Moses and Cobb, Radical Equations, 80.

1086 Carson, In Struggle, 109.

1087 Highlander Research and Education Center, INC., "Highlander and Education for SNCC and COFO."

1088 Student Nonviolent Coordinating Committee, "Mississippi Summer Project," KPKC, 141:14.

1089 Ibid.

1090 Ibid.
} 
black people using their political power. The law students tried to sue the tyrannical officials. $^{1091}$

Concerning the HFS's charge to train white students, the students, who were invited to work as volunteers for the Freedom Summer Project, came from Northern colleges, and 90 percent of them were white. ${ }^{1092}$ The volunteer students had to take the risk of being lynched in the most dangerous area in the Southern states — the Deep South — and they were required to pay $\$ 150$ for their personal expenses and $\$ 500$ in case they needed bail. ${ }^{1093}$ Clark supervised the training of the voting rights activists in this project. ${ }^{1094}$ Among the first group of volunteers for the Freedom Summer of COFO were Andrew Goodman, who was a white student from Queens College in New York; Michael Schwerner, who was a white student from Columbia University in New York; and James Chaney, who was a young black CORE worker and a native of Mississippi. On Sunday, June 21, 1964, the bodies of these three CORE workers were found after the young men had been missing for forty-four days; they had been shot and beaten to death. ${ }^{1095}$ These three CORE workers were on their way back from investigating the burning of the Mount Zion Methodist Church in the Longdale community, which was an all-black community and located in Neshoba County, Mississippi.

Moses had asked Robinson to operate workshops for COFO's projects, and the HFS had taken charge of training the white volunteer students who came from the North. ${ }^{1096}$ The murder of these three CORE workers and the attack on Mount Zion Church were reprisals of the white racists of Neshoba County against Schwerner's voting rights efforts in the

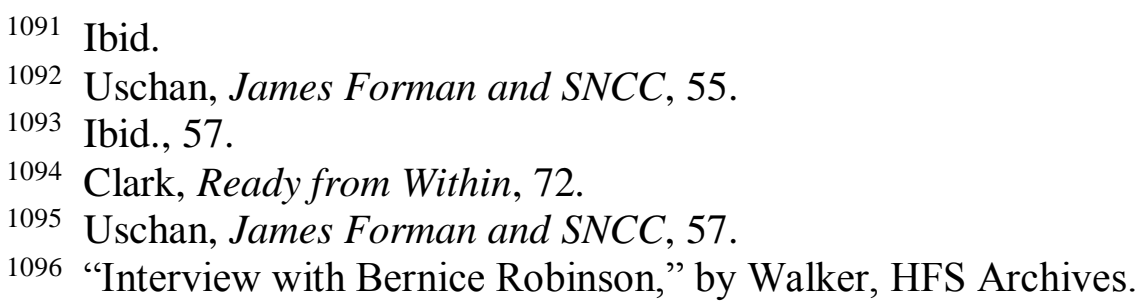


church. ${ }^{1097}$ Schwerner had been working on voter registration drives around Meridian in Mississippi for about six months before the murder. He had delivered a speech at the Mount Zion Church two weeks before the church was burned and the church people were beaten by white racists. In this sermon, he had said, "You have been slaves too long ... we can help you help yourselves." 1098 Schwerner had suggested that the church people use their church for voter education: "Meet us here, and we'll train you so you can qualify to vote."1099 The description of Schwerner's speech demonstrates that he shared the same philosophy of teaching with the Citizenship School, that of promoting the grassroots people's selfawareness and training the people to vote. The tragedy of his and the other two men's deaths was reminiscent of the murder of the four young girls by the bombing of the Sixteenth Street Baptist Church on September 15, 1963. White racists had bombed the basement of the church where CEP staffers were training young demonstrators for voting rights and nonviolent resistance during the Birmingham Campaign. ${ }^{1100}$

Voter registration efforts were targeted by white racists because they brought real political changes to local African American communities. ${ }^{1101}$ During the voting rights movement, there were thirty-five churches among the sixty-five houses and buildings hosting voting rights efforts that were bombed, and there were thirty-five cases of gunfire. ${ }^{1102}$ Even though the murders of the Freedom Summer Project were tragic, the murders gained nationwide attention and caused anguish about the inhuman brutality of racism. ${ }^{1103}$ The

1097 Seth Cagin and Philip Dray, We Are Not Afraid: The Story of Goodman, Schwerner, and Chaney and the Civil Rights Campaign for Mississippi (New York: Nations Book, 2006), 12.

1098 Ibid., 2.

1099 Ibid.

1100 See page 256.

1101 Greenhaw Wayne, Fighting the Devil in Dixie: How Civil Rights Activists Took on the Ku Klux Klan in Alabama (Chicago: Lawrence Hill Books, 2011), 165.

1102 Uschan, James Forman and SNCC, 59; and Garrow, Protest at Selma, 21.

1103 Carson, In Struggle, 115. 
hundreds of white volunteer students also challenged the unwillingness of local black people to take the risk of resisting racism because the white students worked hard for African Americans' voting rights despite the risk. ${ }^{1104}$ This attitude of the white volunteers encouraged local black people in Mississippi to trust and help each other. ${ }^{105}$ After these voting rights efforts during the summer, the Freedom Summer Project had helped just 1,600 black Mississippians out of 17,000 people who had tried to register succeed in getting registered, and the MFDP had gained 80,000 black members. ${ }^{1106}$ However, one of the Freedom Summer's goals was to train thousands of volunteer students to become leaders of homegrown voting rights activities in their communities after the project. ${ }^{1107}$ Despite the cruel attacks of white racists in Mississippi, the volunteers of COFO kept the radical nonviolent movement as their major tactic. Thus, they could continue their voting rights movement in Selma and expand their radicalism into the anti-Vietnam War movement. ${ }^{1108}$ According to John Lewis, as part of the impact of COFO's efforts, there were 300,000 black people who were able to newly register during the next decade of the Freedom Summer Project. ${ }^{1109}$

The MFDP failed to gain a seat at the Democratic Party convention. Moses and other COFO staffers were disappointed at this result, and the failure of the MFDP made SNCC people feel tired out, like they had received "a knockout punch." 1110 However, Hamer's speech at the Democratic Credentials Committee, "I Question America," became a legendary witness for awakening the consciences of American people. ${ }^{1111}$ Moreover, the MFDP

\footnotetext{
1104 Ibid., 111.

1105 Ibid., 115.

1106 Ibid., 117.

1107 Ibid., 110.

1108 Ibid., 129.

1109 Lewis, Walking with the Wind, 282.

1110 Ibid., 293.

1111 Branch, Pillar of Fire, 457.
} 
continuously worked to promote the voting rights and political power of African Americans after the Democratic National Convention in 1964, and grassroots women leaders such as Fannie Lou Hamer, Victoria Gray, and Annie Devine were able to provide leadership to the civil rights movement through the MFDP's political activities.

Hamer's speech to the Democratic Credentials Committee was the climax of the activities of the MFDP during the Freedom Summer Project. Hamer began her speech in front of the white-dominated committee with the following words: "Mr. Chairman and Credentials Committee, my name is Mrs. Fannie Lou Hamer, and I live at 626 East Lafayette Street, Rulerville, Mississippi." 1112 This comment represented that she herself was the Deep South. Comparing herself to the prominent clerical leaders of the civil rights movement such as King, Hamer witnessed that the grassroots people of the Deep South were the center of the struggles with the American segregation system and that they also should be the hub of the civil rights movement. Hamer's question, "Is this America?" which was broadcast to millions of people, testified that the civil rights movement should be achieved not through the top leaders' dreaming, but through the restoration of the humanity of grassroots people in the Deep South and through the consciences of American people. ${ }^{113}$

Hamer's grassroots testimony declared the transition of the leadership of the civil rights movement from the elite leaders to the grassroots people. In 1963, King's "I Have a Dream" speech represented the voice of the elite leadership of the civil rights movement, which had been highlighted by mass movements; however, Hamer's speech expressed the voice of the underprivileged people of the Deep South, who had to be the subjects of the redemption of the sickness of American society. While Hamer was singing spirituals during the Democratic National Convention such as "Go Tell It on the Mountain" and "Go Down

1112 Hamer, "Testimony before the Credentials Committee, DC Convention." 1113 Marsh, God's Long Summer: Stories of Faith and Civil Rights, 38. 
Moses," whose narrators (African slaves) identify themselves as biblical prophets, Hamer's speech equalized the voices of the oppressed people who were the subjects of the civil rights movement. ${ }^{1114}$ This testimony was precisely a practicing of the self-awareness tactic that Christian women leaders highlighted in the Citizenship School. King was the only person who was spotlighted by his "I Have a Dream" speech because it depended on the elite leader's philosophy; however, Hamer's “I Question America” placed a spotlight on underprivileged people because it represented the voices of the grassroots people in the Deep South. The development of the Citizenship School's grassroots leadership enabled Hamer's powerful testimony to be heard nationwide. Hamer's speech was an exemplary practice of the grassroots leadership of the Citizenship School, which highlighted the voices of multiple leaders who shared horizontal leadership.

Even though COFO was not a religious civil rights organization, the voting rights movement of the organization was dependent on Christian morality, just as the Citizenship School and the CEP were. Hamer's struggle for freedom involved appealing to people nationwide through her singing of freedom songs, whose lyrics were based on spirituals. During the Freedom Day movement in Mississippi, Forman and twelve other people engaged in a kneel-in demonstration and prayed outdoors when the sheriff refused to open the door of the courthouse so they could register to vote. Because of heavy rain, Forman tried to help a seventy-one-year-old woman who wanted to register to enter the building. When the sheriff blocked the door, Forman pleaded with him, "Sheriff, will you be a Christian and let this old lady inside?"1115 Despite life-threatening conditions, the Freedom Summer Project was mostly based in church buildings in Mississippi. Joyce Brown, who was a sixteen-year-old

\footnotetext{
1114 Ibid., 36.

1115 Uschan, James Forman and SNCC, 58.
} 
girl and a graduate of the Freedom School of McComb, urged local church people by sending letters with the following poem she had written:

I asked for your churches, and you turned me down, But I'll do my work if I have to do it on the ground, You will not speak for fear of being heard, So crawl in your shell and say, 'Do not disturb.",1116

Brown's letters encouraged the churches in Mississippi to open their buildings for the operation of voter education programs. ${ }^{1117}$ In COFO's statement "We'll Never Turn Back," which was signed and submitted by Annell Ponder, Willie Peacock of SNCC, Andrew L. Jordan of the NAACP, and David J. Dennis of CORE, one of the fifteen principles states, "We Believe, -that you know it is unChristian and undemocratic to deliberately keep good education, good housing, good jobs, and protection of the law away from a person because of his color." "1118 The nonviolent tactics of COFO could be maintained because its voting rights education was heavily dependent on church people and church buildings, despite cruel violence in Mississippi.

Using their training from the Citizenship School, COFO people could expand their voting rights movement in Mississippi through grassroots tactics for training local people. The Freedom Summer Project was a great transition in SNCC, which had been focusing on direct actions. This transition also meant that SNCC staffers made a decision to create a means of motivation that could mobilize local black people who lived in poverty and were illiterate. ${ }^{119}$ This transition, which was made by COFO, paralleled the transition of SCLC through the success of the CEP. Clark's Citizenship School program made this transition, and Robinson's supervision of the program produced and developed the grassroots leaders of

1116 Joyce Brown, letter to local churches, cited in John Dittmer, Local People: The Struggle for Civil Rights in Mississippi (Urbana: University of Illinois Press, 1994), 268.

1117 Uschan, James Forman and SNCC, 59.

1118 Mississippi COFO Publication, n.d., "We'll Never Turn Back," KPKC, 141:14.

1119 Carson, In Struggle, 82. 
SNCC and COFO during this period. The Freedom Summer Project was essentially dependent on the grassroots tactics of the Citizenship School, which sent the young civil rights activists of SNCC and COFO to the local underprivileged people in Mississippi. In the same way that Clark promoted a determined spirit through the Citizenship School program, as trainees of Clark's workshops, the voting rights activists of SNCC and COFO were willing to receive death threats for operating the voting rights movement in the Mississippi Delta. The murders of three voting rights activists of CORE were eulogized as martyrdom for building an integrated society, the beloved community of Clark's faith (the MFDP also displayed the documents, notes, and burnt car of the three activists as symbols of their martyrdom during the Democratic National Convention). ${ }^{1120}$ Moreover, through the impact of Robinson's supervision, grassroots civil rights activists such as Hamer and Schwerner were able to develop voter registration drives in local areas of Mississippi, and their sufferings revealed the brutality of racism to people nationwide. The voter registration efforts of grassroots civil rights leaders, who practiced Christian nonviolent tactics (as taught to them by Clark and Robinson) at church buildings in spite of life-threatening risks, came to be supported by people across the nation, and their contributions paved the way to success in the movement for voting rights in Selma.

\section{The St. Augustine Movement and the Voting Rights Workshops of the CEP}

During 1962, Hosea Williams worked as the president of the Savannah Voters Crusade, which was a SCLC affiliate. Like Hamer, he was one of the trainees of Clark's Citizenship School, and he recruited local people for the voting rights movement according to what he had learned from Clark. ${ }^{1121}$ He operated the citizenship schools in Savannah, Georgia, and sent young people to the Dorchester Center to learn the voter registration

1120 Clark, Ready from Within, 71-76; and Marsh, God's Long Summer, 36.

1121 Clark, Ready from Within, 70. 
program. ${ }^{1122}$ Williams also recruited young people in Savannah to educate them with the CEP's Citizenship School program. ${ }^{1123}$ Through boycotts and demonstrations, Williams shaped the Savanah movement along with the trainees of the citizenship schools. Williams requested that King and other SCLC staffers come to help the Savannah movement, but the staffers were exhausted after the Birmingham Campaign. Even without the strong help of the key leaders of SCLC, Williams was able to organize successful voter registration drives in Savanah through applying the tactics of the Citizenship School. ${ }^{1124}$

The achievements in Savannah made Williams one of the key leaders of SCLC in terms of voter registration drives. When the dentist Dr. Robert Hayling, who was the president of SCLC's affiliate in St. Augustine, Florida, and Dr. Vincent Harding asked King and SCLC staffers for help for their movement, King sent Cotton and Williams to investigate the movement in St. Augustine and the ability to operate CEP workshops there before King and other staffers arrived. ${ }^{125}$ As he did in Savannah, Williams organized about thirteen CEP workshops with Cotton and enacted sit-ins, boycotts, and night marches (with the latter being the first attempted by SCLC). ${ }^{1126}$ Young personally opposed King's participation in the St. Augustine Movement because it was too dangerous. However, King came to St. Augustine to support the movement there even though there were life-threatening risks everywhere in the city. During the night marches, white mobs attacked Cotton, Young, and other demonstrators with bricks and bottles. Young was severely beaten by blows from fists and a blackjack. ${ }^{1127}$ Enduring death threats during the night marches, the demonstrators of the St. Augustine Movement regularly marched forth-five nights. ${ }^{1128}$ Cotton and Williams were able to carry

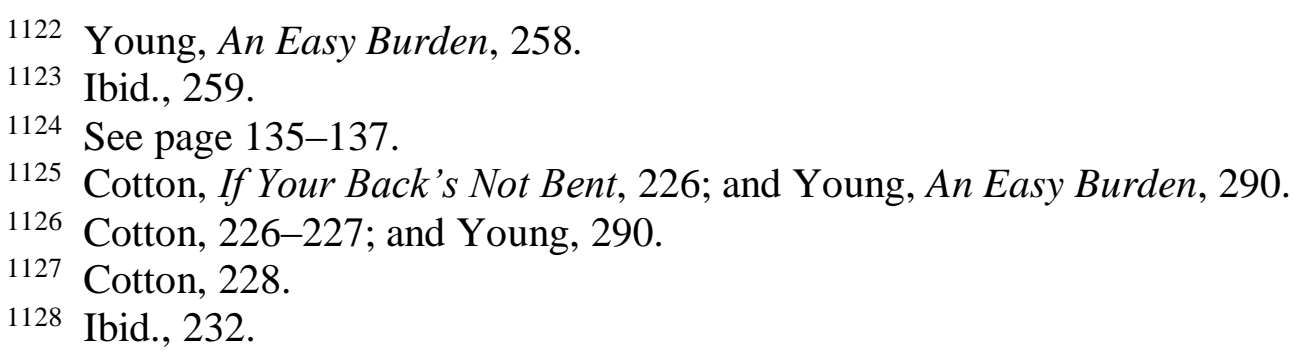


out the most dangerous campaign of SCLC through training young students at "the Freedom House."1129

At the Freedom House, Cotton and Williams trained young students in nonviolent tactics, and they organized children marchers to wade in the water at a whites-only beach. Cotton and the young students were beaten by white mobs. However, the resistance of the brave young students energized the adult demonstrators, who were tired of receiving death threats while maintaining nonviolent tactics. ${ }^{1130}$ The St. Augustine Movement gained worldwide attention, which finally led the Florida attorney general to act on passing the civil rights bill. ${ }^{1131}$ In lobbying the US Congress to pass the civil rights bill, many civil rights leaders, including Hamer and Annell Ponder, stressed the importance of the bill. The filibuster against the civil rights bill was terminated on June 10, and the public facilities of St. Augustine were desegregated, as the social activists had demanded. ${ }^{1132}$ According to Young, he believed that "still, it may be that we would not have had a Civil Rights Act without St. Augustine."1133 The St. Augustine Movement also contributed to encouraging African American voters to register. According to the local newspapers of St. Augustine, with the near-at-hand November election of 1964, there was a noticeable increase in the number of African American registrations to vote after the St. Augustine Movement. ${ }^{1134}$ According to the supervisor of registration at the time, Mrs. T. F. Ellzey, "approximately 500 Negroes have been added to the voter rolls since the May primary. . . . This is the heaviest registration of Negroes in so short a period of time during my 20 years as supervisor of registration." 1135

\footnotetext{
1129 Ibid., 229-230; and Young, 296.

1130 Cotton, If Your Back's Not Bent, 231.

1131 Young, An Easy Burden, 296.

1132 Ibid., 298.

1133 Ibid., 297.

1134 "Negroes Step up Their Registration Program Here; County Books for November Election Close Oct. 3," St. Augustine Record, September 21, 1964, KPKC, 139:8. 1135 "St. Johns Negroes Hold Vote Registration Drive," Florida Times-Union, September 22, 1964, KPKC, 139:8.
} 
The CEP's workshops for training local young people played a key role in the success of the St. Augustine Movement. Williams trained local people as militant demonstrators who did not fear the death threats of white mobs. As Bevel and Nash did with the Birmingham Campaign, the CEP workshop developed its organizing skills to educate and recruit local grassroots people to fight for freedom. This development of the CEP also enabled the Selma to Montgomery marches to achieve their goal. As the Birmingham Campaign did, the St. Augustine Movement demonstrated that multiple grassroots leaders led the civil rights movement by using the Citizenship School's tactics for training and mobilizing local people.

\section{The Power of Voting Rights Workshops for the Selma to Montgomery Marches}

The voting rights movement in Selma was initiated by Sam and Amelia Boynton in the late 1940s. Despite the economic reprisals of white racists in Selma, the Boyntons had worked for the human rights of local black people with the NAACP branch in Selma. ${ }^{1136}$ Along with Amelia Boynton's close friend Marie Foster, the Boyntons initiated the Dallas County Voters League to encourage black people to vote. The voting rights movement in Selma demonstrated the collaborative efforts of local grassroots leaders and the nationwide civil rights organizations for voting rights. The activists of SNCC and COFO began to come to Selma for the voter registration drives in 1962. As trainees of Clark's Citizenship School program, Amelia Boynton and the voting rights activists of SNCC and SCLC used grassroots leadership to break through the tension between the local people and the newly arrived staffers of the nationwide civil rights organizations. Septima Clark began to train the staffers of SNCC from its initial year of 1960, and there were many trainees of Clark who went to Selma for the voting rights movement as field workers of SNCC and CORE during the Birmingham Campaign. ${ }^{1137}$ Bernice Robinson and Annell Ponder helped the voting rights

1136 Wayne, Fighting the Devil in Dixie, 163.

1137 Clark, Ready from Within, 60-72. 
activists of SNCC, COFO, CORE, and SCLC set up Citizenship School programs and the strategies of the voter registration drives in Selma. ${ }^{1138}$

In December 1964, after he had come back from Norway, where he had received the Nobel Peace Prize, Martin Luther King Jr. met with President Lyndon Johnson. President Johnson persuaded King to wait on passing the voting rights bill because there were other bills that needed to be passed. ${ }^{1139}$ King rejected President Johnson's suggestion, and he tried to make the demand for voting rights the major program of SCLC over the next year. King knew that James Bevel already had planned for the voting rights movement in Selma. ${ }^{140}$ However, SCLC had to consider that SNCC had been working for voting rights in Selma since 1962. ${ }^{1141}$ As a trainee of Clark's workshop, Reggie Robinson of SNCC began to work for the voting rights project in Selma in 1962. The full-time workers of SNCC, Bernard Lafayette, who was also a trainee of Clark's Citizenship School, and his wife Colia, began the voting rights education program in Selma in February 1963. ${ }^{1142}$ Even though there was an increase of interest in fighting for voting rights with the help of James Bevel's speech at one meeting, voter registration began to decrease because the people in Selma feared economic reprisals and the pressure of police observation by James G. Clark, Jr., the sheriff of Dallas County, Alabama. ${ }^{1143}$ When the Lafayettes left Selma, SNCC sent Worth Long, James Forman, and John Lewis to develop the voting rights movement in Selma. ${ }^{144}$

As they learned about the training and mobilizing tactics of the Citizenship School program from Clark and Robinson, Long, Forman, and Lewis helped the local youngsters enact sit-ins and the Freedom Day to encourage local people to register to vote in the fall of

\footnotetext{
1138 "Interview with Bernice Robinson," by Walker.

1139 King, The Autobiography of Martin Luther King, Jr., 270.

1140 Ibid., 273.

1141 Young, An Easy Burden, 337.

1142 Garrow, Protest at Selma, 31.

1143 Ibid., 32.

1144 Ibid.
} 
1963. Sheriff Clark and his police officers used tear gas on the demonstrators and jailed them. ${ }^{1145}$ By 1964, just 156 African Americans were registered to vote, as opposed to the 15,000 black voters who were eligible to vote in Selma. ${ }^{1146}$ There had been increasing needs for support from the key civil rights organizations for the Selma movement because there had been the strong oppression of the police department against black civil rights movement and a low rate of voter registration in Selma. After the Freedom Summer Project, the leadership of SNCC was in crisis. Even though Lewis, Forman, and Moses were continuing in their leadership positions for SNCC, there were increasing doubts about their qualifications for these positions among SNCC members in Northern cities. These complaints were based on red-baiting rumors and the failure of the MFDP to win seats at the Democratic Convention. ${ }^{1147}$ Thus, to win trust, SNCC leaders began to plan to focus on increasing the scale of the voting rights movement in Selma to become as large as the Birmingham Campaign. ${ }^{1148}$

In these circumstances, the Dallas County Improvement Association, whose members were local activists in Selma, asked SCLC to come down to Selma to help their movement. Among the local activists from Selma, there was a key person who persuaded SCLC staffers to go to Selma. This person was Mrs. Amelia Boynton, who was a graduate of the Citizenship School and a colleague of Bevel and Young. ${ }^{1149}$ SNCC staffers in Selma felt uncomfortable with SCLC's engagement because they had already pioneered the voter registration drives in Selma, which work was inevitably ignored because of SNCC's major effort of the Freedom Summer Project, and SCLC tried to take over their movement in Selma. ${ }^{150}$ However, based

1145 Lewis, Walking with the Wind, 312.

1146 Ibid., 312-313; and Garrow, Protest at Selma, 34.

1147 Lewis, 310.

1148 Ibid., 313.

1149 Young, An Easy Burden, 338.

1150 Lewis, 314. 
on the request of the native activists in Selma and on Mrs. Boynton's persuasion, King and SCLC officially announced that they were launching a campaign in Selma on January 2, 1965. Dorothy Cotton and Septima Clark stayed in Boynton's home during the movement in Selma. ${ }^{1151}$ King's wife, Coretta Scott King, who was born and raised in Marion, also joined the movement in Selma.

On February 18, Jimmie Lee Jackson, who was twenty-six years old and had failed to register to vote during the last four years, welcomed SCLC staffers' help with the local people's voter registration drive. ${ }^{1152}$ As had happened with SCLC's night marches for the St. Augustine Movement, when Jackson marched at night to the Perry County jail from Zion United Methodist Church in Marion with SCLC people who were led by C. T. Vivian, the police officers beat the marchers, including Jackson's mother and grandfather. Jackson was shot when he tried to protect his mother and grandfather, who escaped to Mack's Café. ${ }^{1153}$ Jackson's fatal injury and death in Marion (which was near Selma) aroused people nationwide to pay attention to Selma and support the direct actions against police brutality. At Jackson's funeral service, Bevel suggested taking Jackson's body on the march to Montgomery from Selma. ${ }^{154}$ During the service, Bevel and Nash announced that the march was scheduled for Sunday, March 7. ${ }^{1155}$ However, after heated discussion, SNCC staffers made a decision to support the march individually. ${ }^{1156}$

\footnotetext{
1151 Young, An Easy Burden, 343.

1152 Craig Swanson, The Selma Campaign: Martin Luther King, Jr., Jimmie Lee Jackson, and the Defining Struggle of the Civil Rights Era (Bloomington: Archway Publishing, 2014), 109; and Bruce Hartford, The Selma Voting Rights Struggle \& the March to Montgomery (San Francisco: Westwind Writers, 2014), 70.

1153 Ibid., 328.

1154 Lewis, Walking with the Wind, 329.

1155 Cotton, If Your Back's Not Bent, 235.

1156 Carson, In Struggle, 158.
} 
Two trainees of Clark's Citizenship School, Bevel and Williams, organized the first Selma to Montgomery march as its chief strategists. ${ }^{1157}$ The march also received international attention because of Jackson's death and King's recent reception of the Nobel Peace Prize. Even though SNCC leaders such as James Forman refused to support the march because it was too dangerous to walk the fifty-four miles with the risk of death threats, Lewis made a decision to participate in the march. ${ }^{1158}$ At Brown Chapel AME Church near the Edmund Pettus Bridge, about four or five hundred people gathered to march. King could not postpone the march; however, he had to conduct a baptism and the Lord's Supper at his church in Atlanta. Before the march began without him, King called Young to advise that Lewis march in the first row, with Bevel or Williams walking with him and with the other man taking care of the people who were at the end of the line of marchers. ${ }^{159}$ Thus, Bevel and Lewis walked in the first line, and Boynton and the people of the Dallas County Improvement Association walked after them. There were teenagers, old people, and many people of Selma who walked in the front row. Young and Williams walked in the last row of marchers. ${ }^{1160}$ When the marchers approached the Edmund Pettus Bridge, police officers shot tear gas and the troopers hit the marchers with billy clubs. There were white mobs on the side of the road who were hollering insults at the marchers and cheering the troopers. ${ }^{1161}$

Mrs. Boynton was attacked and fell down, and Lewis received a blow on his head. Many people were severely injured by blows from police clubs and whips. This march began to be called "Bloody Sunday." 1162 In the chaos, the marchers were scattered into the area of the Brown Chapel Church. Among the white mobs, an FBI agent attacked cameramen. ${ }^{1163}$

\footnotetext{
1157 Young, An Easy Burden, 355.

1158 Ibid.

1159 Ibid., 355; and Lewis, Walking with the Wind, 336.

1160 According to Lewis, Williams walked with him at the front.

1161 Lewis, 339.

1162 Garrow, Protest at Selma, 77.

1163 Lewis, Walking with the Wind, 342.
} 
About 150 troopers and deputies who were armed and received an order from Governor George C. Wallace brutally attacked the marchers, and over 50 marchers were wounded. ${ }^{1164}$ $\mathrm{ABC}$ television reported on the bloody march at nine p.m., cutting into the Sunday evening movie. National newspapers headlined vivid pictures of the police brutality against the marchers in Selma on Monday morning. ${ }^{1165}$ These media reports evoked worldwide bitterness toward the inhumanity of US public authorities. SCLC announced that the second march was scheduled for March 9. On the eve of the march, several SNCC staffers came from Mississippi filled with guilt about their absence from the previous emergency. There was a meeting of the leaders of SNCC, CORE, and SCLC to prepare for the march the day before it was scheduled to occur. ${ }^{1166}$

On March 9, Judge Frank M. Johnson of the federal district court for Montgomery issued an order restraining King and the local civil rights leaders from marching to Montgomery from Selma. ${ }^{167}$ Resenting the issuance of this restraining order, King led about two thousand people to the Pettus Bridge. On the bridge, the marchers stopped in front of a US marshal who warned them that the march was against the order of Judge Johnson. King led the marchers to pray and sing "We Shall Overcome."1168 Then the marchers turned back to Brown Chapel Church. Most marchers were shocked because they did not expect that the march would simply end in turning back. SNCC staffers especially, who were tired of the rules and insisted on ignoring the judge's order, criticized King's leadership on the turnaround march. ${ }^{169}$ Despite their complaints, the march was integrated, with people of diverse religions, civil rights organizations, and labor unions participating. King invited

\footnotetext{
1164 Garrow, Protest at Selma, 76.

1165 Ibid., 78.

1166 Lewis, Walking with the Wind, 346.

1167 King, The Autobiography of Martin Luther King, Jr., 280.

1168 Lewis, 348.

1169 Ibid., 349.
} 
religious leaders to participate in the march, and over four hundred religious leaders came from other states for the event. Unitarian pastor James J. Reeb, who came from Boston, was severely beaten by a club and a baseball bat by a group of white racists, and he received a fatal injury to his head. ${ }^{1170}$ The death of Pastor Reeb intensified the nationwide outrage and the need for the Voting Rights Act. President Johnson delivered a speech in which he said, "What happened in Selma is part of a far larger movement which reaches into every section and state of America. ... Because it is not just Negroes, but really it is all of us who must overcome the crippling legacy of bigotry and injustice. And we shall overcome."1171 However, African American civil rights activists felt bitter about the fact that the death of the white pastor Reeb was highlighted more by the mass media than that of the black demonstrator Jimmie Lee Jackson. ${ }^{1172}$

Judge Johnson issued an order to allow the Selma to Montgomery march, and he granted permission for the marchers to use two lanes of Highway 80. President Johnson ordered the Alabama National Guard to protect the marchers. ${ }^{1173}$ The administrative committee of the Selma movement set the date of the march for Sunday, March 21. They set up a plan for walking fifty-four miles within five days. The staffers of the movement prepared campsites, even though over 4,500 marchers could not sleep at them (most of them returned home and came back the next day to join the march again). The National Council of Churches supplied food, and the Medical Committee for Human Rights provided medical services. ${ }^{1174}$ The march began by departing from Brown Chapel Church. SNCC, SCLC, the NAACP, and the Urban League joined the march with their full support. ${ }^{1175}$ The marchers

\footnotetext{
1170 Ibid., 350.

1171 Ibid., 353.

1172 Young, An Easy Burden, 362.

1173 Ibid., 363.

1174 Ibid., 365.

1175 Lewis, Walking with the Wind, 355.
} 
were members of almost all the major civil rights organizations, diverse religious leaders, old people, and little children. Martin Luther King, Jr., Coretta Scott King, Hosea Williams, John Lewis, Andrew Young, and A. Philip Randolph, along with other civil rights and religious leaders, always walked in the first row of the march. Despite the burning sun during the day and chilly nights, nobody complained. The marchers sang freedom songs, reveled in performances from celebrities such as Peter, Paul and Mary and Joan Baez, and enjoyed dinner parties at the campsites. ${ }^{1176}$

On the fifth day of the march, over 50,000 people gathered with the marchers at the Alabama State Capitol in Montgomery. King delivered a speech titled, "How Long? Not Long." 1177 In his speech, King stressed the goal of the march: "Our whole campaign in Alabama has been centered around the right to vote."1178 King repeated several times the phrase, "Let us march on ballot boxes." "1179 He insisted that voting rights could guarantee the “decency and honor" of God's children. ${ }^{1180}$ As he confirmed that the Voting Rights Act would be enacted, King proclaimed, "Mine eyes have seen the glory of the coming of the Lord."1181 King was delighted by the ecumenical marchers who were Jews and Catholics and had not participated in the civil rights movement before. He believed that "Selma brought into being the second great awakening of the church in America." ${ }^{1182}$ During the dispersion of the marchers, Viola Liuzzo, a white woman from Detroit who had given rides to the marchers, was killed by white racists. On August 6, 1965, the Voting Rights Act was passed

\footnotetext{
1176 Ibid., 359.

1177 King, The Autobiography of Martin Luther King, Jr., 284.

1178 Ibid.

1179 Ibid., 285.

1180 Ibid.

1181 Ibid.

1182 Ibid., 287.
} 
by the US Congress and signed by President Johnson. SCLC considered "the Voting Rights Act of 1965 as one of the most monumental laws in the history of American freedom." $" 1183$

The success of the Selma to Montgomery marches was based on local voter registration efforts in Selma. Sam Boynton, the husband of Amelia, who persuaded SCLC to come to Selma to help with the voting rights movement there, had been working for the voter registration drive as the founder and president of the Dallas County Voters League since the late 1940s. ${ }^{1184}$ When her husband began suffering from high blood pressure in the early 1960s, Amelia Boynton took his position. The Boyntons had studied at the Tuskegee Institute to develop the African American community and had worked with the voting rights activists of SNCC, such as Bernard and Colia LaFayette, James Forman, and John Lewis. ${ }^{185}$ Sam Boynton died in 1963, and Amelia Boynton kept the voting rights movement in Selma going. She also was trained at the Citizenship School and was able to host CEP workers during the Selma to Montgomery marches. When the coalition of SNCC, SCLC, and the Dallas County Voters League began to initiate the Selma to Montgomery marches, this coalition used as their headquarters the SNCC office that Sam Boynton had used when organizing the voter registration drives. ${ }^{1186}$ Sharing of local information and experience by the Boyntons could have heavily impacted the success of the short period of the Selma movement. ${ }^{1187}$

The Selma to Montgomery marches were organized by the CEP workers James and Nash Bevel, Young, and Williams. As Young testified, the grassroots leadership that they learned from the Citizenship School led them to successfully cooperate with local civil rights activists from the Birmingham Campaign. ${ }^{1188}$ SNCC leaders who played an essential role in

\footnotetext{
1183 Ibid., 289.

1184 Greenhaw, Fighting the Devil in Dixie, 162.

1185 Ibid., 165.

1186 Ibid., 171.

1187 Garrow, Bearing the Cross, 370.

1188 Young, An Easy Burden, 189, 342.
} 
the Selma movement were Forman and Lewis. These two leaders were graduates of the Citizenship School and workers in the citizenship education program of SNCC. The tension between the statewide civil rights organizations and the local organizations was melted by the shared simple and solid goal of voting rights for African Americans. ${ }^{1189}$ As Septima Clark taught the tactics and participated in almost all the voting rights movements from the Birmingham Campaign to the Selma to Montgomery marches, the "training and mobilizing" tactics of the Citizenship School were foundational to the success of the voting rights movement in Selma, just as they had contributed to the successes of the Birmingham Campaign, the Freedom Summer Project, and the St. Augustine Movement. ${ }^{1190}$ The tactics of the Citizenship School formed the essential background of the Selma movement; Jimmie Lee Jackson's mother and grandfather attended the meeting for the voter registration drive at the church and participated in the march; and Sam and Amelia Boynton promoted the voter education program with SNCC and led the marches for voting rights in Selma. Clark witnessed to the powerful influence of the Citizenship School on the civil rights movement: "One time I heard Andy Young say that the Citizenship Schools were the base on which the whole civil rights movement was built. And that's probably very much true."1191

In Selma, the grassroots leadership model of the Citizenship School, which promoted multiple leaders, enabled the local movement of the Boyntons and the efforts of the national civil rights organizations to be combined for training to promote voting rights and to mobilize for the marches for desegregating voter registration. Because of strong requests from SNCC, CORE, and the NAACP, Clark and Robinson supervised and trained almost all the grassroots leaders from the Birmingham Campaign to the Selma to Montgomery marches. During 1963,

\footnotetext{
1189 Ibid., 369.

1190 Ibid., 189; and "Interview with Septima Poinsette Clark," by Eugene Walker, July 30, 1976, Atlanta, Georgia, HFS Archives.

1191 Clark, Ready from Within, 70.
} 
SNCC asked Clark, "Do come over to Mississippi, and help us train these people to fill in the application blank for registration.""1192 CORE requested, "Please send a member of your staff to help organize the youth in this community and teach them the Freedom Songs. We also need help in the planning of a voter registration campaign." 1193 One of the NAACP chapter presidents pleaded with Clark, "May I bring my NAACP members to a training session? Our members need your help." 1194 Clark and Robinson responded to these requests, and their trainees developed successful voting rights movements in Birmingham, Selma, St. Augustine, and Mississippi. Clark helped her trainees realize their responsibility for fighting for their own rights, and she promoted "spiritual courage to stand uncompromisingly for the religious concept of the dignity and worth and moral responsibility of the individual soul in the eyes of a sovereign God." 1195 In Selma, Clark's grassroots leadership was able to unify the local people and diverse civil rights activists who came from different civil rights organizations to pursue the common purpose of demanding equal voting rights. With the cessation of the internal conflicts in the civil rights organizations and with the inspiration of a determined spirit for human rights, the trainees of Clark's workshop successfully initiated and led the voting rights movement through training and mobilizing grassroots people. Through the tactics of the Citizenship School, the multiple grassroots leaders who had been trained by Christian women leaders came to be awakened by a determined spirit and led the civil rights movement, which had depended on top-down leaders before the Birmingham Campaign.

After the Voting Rights Act of 1965 was enacted, the number of African American voters registered to vote in Alabama almost doubled, from 116,000 in 1965 to 228,000 in 1966. ${ }^{1196}$ From 1962 to 1966 , there were about 10,000 teachers who were trained by the

1192 Clark, "Success of SCLC Citizenship School Seen in 50,000 New Registered Voters."

1193 Ibid.

1194 Ibid.

1195 Ibid.

1196 Young, An Easy Burden, 369. 
citizenship schools and 700,000 African Americans who registered to vote in the South. ${ }^{1197}$ Over one million black voters were registered by 1970, and Young was one of the first two African Americans from the Deep South elected to the US House of Representatives. ${ }^{1198}$ In Dallas County, 8,000 African American voters were newly registered by November $1965 .^{1199}$ The percentage of black Mississippians registered to vote increased from 7\% in 1964 to 64\% by $1969 .{ }^{1200}$ After the Voting Rights Act of 1965 was enacted, seventy-two African American public officers were elected in 1965. ${ }^{1201}$ According to these numbers, the voter registration drives of the Citizenship School were successful in the Southern states. As King had highlighted, the movement in Selma brought to black people the first-class citizenship that could change their political and economic situations. ${ }^{1202}$

\section{Conclusion}

The registration of African Americans to vote was one of the essential goals of the civil rights movement. As veterans of the civil rights movement, Christian women leaders had realized through their field experience that educating grassroots people could play a critical role in achieving that goal. Septima Clark discerned the needs of grassroots people in the Southern local areas and created the Citizenship School, which was armed with practical tactics for promoting the self-awareness of oppressed people living in a socially segregated system. The tactics of the Citizenship School were able to break through the long stagnation of SCLC's voter registration drives and other programs because they could reform the hierarchical communication in the organization. SCLC's adoption of the HFS's Citizenship School provided new fuel to encourage fundraising sources and to hire young staffers who

\footnotetext{
1197 Clark, Ready from Within, 70.

1198 Ibid.

1199 James C. Cobb, “The Voting Rights Act 50: How It Changed World,” Time Magazine, August 6, 2015.

1200 Ibid.

1201 Ibid.

1202 King, The Autobiography of Martin Luther King, Jr., 289.
} 
could practically develop the Southern-wide programs that reached illiterate and povertystricken people. The grassroots leadership of the Citizenship School invited young civil rights activists to take over the major projects of the movement, which led to the success of the Birmingham Campaign, the Freedom Summer Project, the St. Augustine Movement, and the Selma to Montgomery marches.

The Christian women leaders of the Citizenship School enlightened the civil rights activists about what the movement supported: self-awareness of human rights. They demonstrated that the self-determination of individuals could not be promoted by orders delivered from hierarchical structures. Because of their experience with freedom movements from the slavery era on, African American church denominations were comfortable handing over grassroots leadership to the Christian women leaders of the Citizenship School, which had researched the black church tradition of freedom movements. The civil rights activities of SNCC, SCLC, COFO, and CORE from 1962 to 1965 demonstrate that the grassroots leadership of the Citizenship School made an impact by training the key leaders of these major civil rights organizations. The "training and mobilizing" tactics of the Citizenship School helped reform the civil rights movement of the early 1960s, which had been dependent on short-term direct actions. The Citizenship School encouraged civil rights activists to practice tactics for promoting nationwide nonviolent resistance against the diehard systems of segregation. Voter registration drives were the most dangerous projects for grassroots people. However, the strong hope for freedom of the people at the grass roots gave them the courage to take life-threatening risks without fear of dying. Their courage was based on the self-awareness that had been promoted by the local voter education programs in the cities of Birmingham, St. Augustine, and Selma and in the state of Mississippi. Church-based citizenship education programs led grassroots people to march like the glory-seekers of God 
toward freedom, and their efforts climaxed in the achievement of the Voting Rights Act of 1965.

\section{Epilogue}

When I found an interview with Coretta Scott King in which she talked about leadership, I was surprised by her statements because she had very different thinking about leadership from the image of her husband as a leader that has been widely known by the media.

I don't think a leader is always someone who is identified by the media as a leader. There are leaders that are not visible. And they are making a difference, and they are inspiring people as well. Ah ... and so, sometimes people mistake a charisma of the leadership. But I think a person that's supposed to be a leader has to have a vision and has to be able to implement that vision. ${ }^{1203}$

Coretta King's definition of leadership demonstrates how the women civil rights leaders had different thinking about leadership from the general images of the civil rights leaders that the media and historical text books have described. Septima Clark, who had realized Coretta King's potentiality for leadership, used to meet Coretta and encourage her to be a leader of the civil rights movement and not to sacrifice her career. ${ }^{1204}$ In her recent published autobiography, My Life, My Love, My Legacy, Coretta King confesses,

I learned later that when I stepped forward that day [for the march in Memphis to continue her husband's work, just a few days after his assassination], some news reports said I was making my debut as a leader. That was not my objective. I had a commitment even larger than Martin's. I wanted to be useful and available to God, and I was praying to God for direction, a way to perfect my life after Martin and to continue our work and follow the calling we had both cherished. I was separated from Martin now, but never from the movement, never from the Cause. ${ }^{1205}$

These statements demonstrate Coretta King's self-awareness of leadership, which corresponded to the grassroots leadership approach of the women civil rights leaders.

1203 "Interview with Coretta Scott King," April, 18, 2008, YouTube Video, 1:18, https://www.youtube.com/watch?v=5lzVxVZcdsY.

1204 Clark, Ready from Within, 79-83.

1205 Coretta Scott King, My Life, My Love, My Legacy: As Told to the Rev. Dr. Barbara Reynolds (New York: Henry Holt and Company, 2017), 167. 
Since Coretta King had frequent contact with Ella Baker and Septima Clark, her statements strongly indicate that she had a philosophy of grassroots leadership that was invisible to the public's interest in creating a hero/heroine but that awakened people to have a vision for social changes, just as Baker and Clark had applied this philosophy to the civil rights movement. ${ }^{1206}$ As Rosa Parks, Bernice Robinson, Dorothy Cotton, and Fannie Lou Hamer had, after the achievement of the Voting Rights Act in 1965, grassroots women leaders were able to continue their grassroots movements at the national level and to expand them internationally. Baker, Clark, Parks, Cotton, Nash, and Coretta King also continued to lead social activities for the rights of minorities with an indefatigable stamina. As leaders "invisible" to the media's interests but also the inspirators of visible historic changes, the women leaders who maintained the tactics of the grassroots movements were able to expand their efforts to movements for the rights of other minority groups. After her husband's assassination, Coretta King did not give up on her vision for promoting human rights and building the beloved community. Having a different religious background from King's elite pastors' family, Coretta King grew up in a family of sharecroppers and laypeople who actively attended a local church. Her family background was closer to the grass roots than her husband's, whose experience was of a middle-class pastor's family living in downtown Atlanta. ${ }^{1207}$ Coretta had learned and worked with grassroots and pacifist movements before her husband became involved in the civil rights movement. Right after King's death, Coretta King expanded her horizons to pacifist, women rights, and LGBT rights movementsmovements that her husband had never had a hand in. ${ }^{1208}$ Coretta King is a great example of the grassroots women leaders who made links between the civil rights movement and the

\footnotetext{
1206 Ibid., 115.

1207 Coretta Scott King, My Life with Martin Luther King, Jr. (New York: Holt, Rinehart and Winston, 1969), 23-28; and King, Stride Toward Freedom: The Montgomery Story, 1-10. 1208 Coretta Scott King, My Life, My Love, 28-29, 172-184.
} 
post-civil rights era. I shine a light on Coretta King as a female leader who was able to engage in diverse human rights movements during and after the civil rights movement as a result of her experiences with the grassroots movements of other women civil rights leaders, such as the Selma to Montgomery marches.

Coretta King was a great supporter of the mass movements led by her husband, and at the same time, she developed her own ideas and visions of grassroots movements, just like her contemporaries, Baker, Parks, Clark, and Hamer. As the grassroots leadership of the women civil rights leaders promoted the whole of the civil rights movement, Coretta King's activities as a woman leader of social movements demonstrate that the women leaders' grassroots movements did not produce friction with the mass movements of the clergymen. The grassroots movements of the women organizers and the mass movements of the clergymen organizers challenged and impacted each other to the effect that both came to seek the universal goal of human rights. Coretta King's grassroots movements helped develop the civil rights movement into a movement that aimed for the co-prosperity of diverse minority groups and of women and men who were suffering from different social problems. The social movements founded by Coretta King demonstrate that the grassroots movements of the women civil rights leaders proved a great source for expanding the civil rights movement into relevant social movements that work for justice for people of diverse minority groups to the present time. As the founder of the King Center, which invites global visitors today, Coretta King established a foundation for transcending the goals of racial and economic justice from the civil rights movement and embracing global visions of equal rights for all people. As leaders not in the media's spotlight, but as inspirators of visible historic changes for people at the grass roots, like Coretta King, women civil rights leaders continue to facilitate social changes for justice throughout time and around the world. 


\begin{abstract}
Abbreviations
In the endnotes, there are abbreviations of archives. Their numbers indicate following archive and manuscript information to stand for box:folder.

AMN Avery Research Center for African American History \& Culture, Charleston, South Carolina.

HFS Papers and Manuscript collection of the Highlander Folk School. The Highlander Research and Education Center, New Market, Tennessee.

KPBU Martin Luther King, Jr. Papers. Boston University Howard Gotlieb Archival Research Center Dr. Martin Luther King, Jr. Archive, Boston, Massachusetts.

KPKC Papers of Dr. Martin Luther King, Jr. and Southern Christian Leadership Conference. The Martin Luther King, Jr. Center for Nonviolent Social Changes, Inc., King Library and Archives, Atlanta, Georgia.

TBWL Papers of Taylor Branch, Research \& Instructional Services Department Louis Round Wilson Special Collections Library, the University of North Carolina at Chapel Hill, North Carolina.
\end{abstract}




\section{Appendix A}

Chart I. Income Chart of SCLC from 1959 to 1965

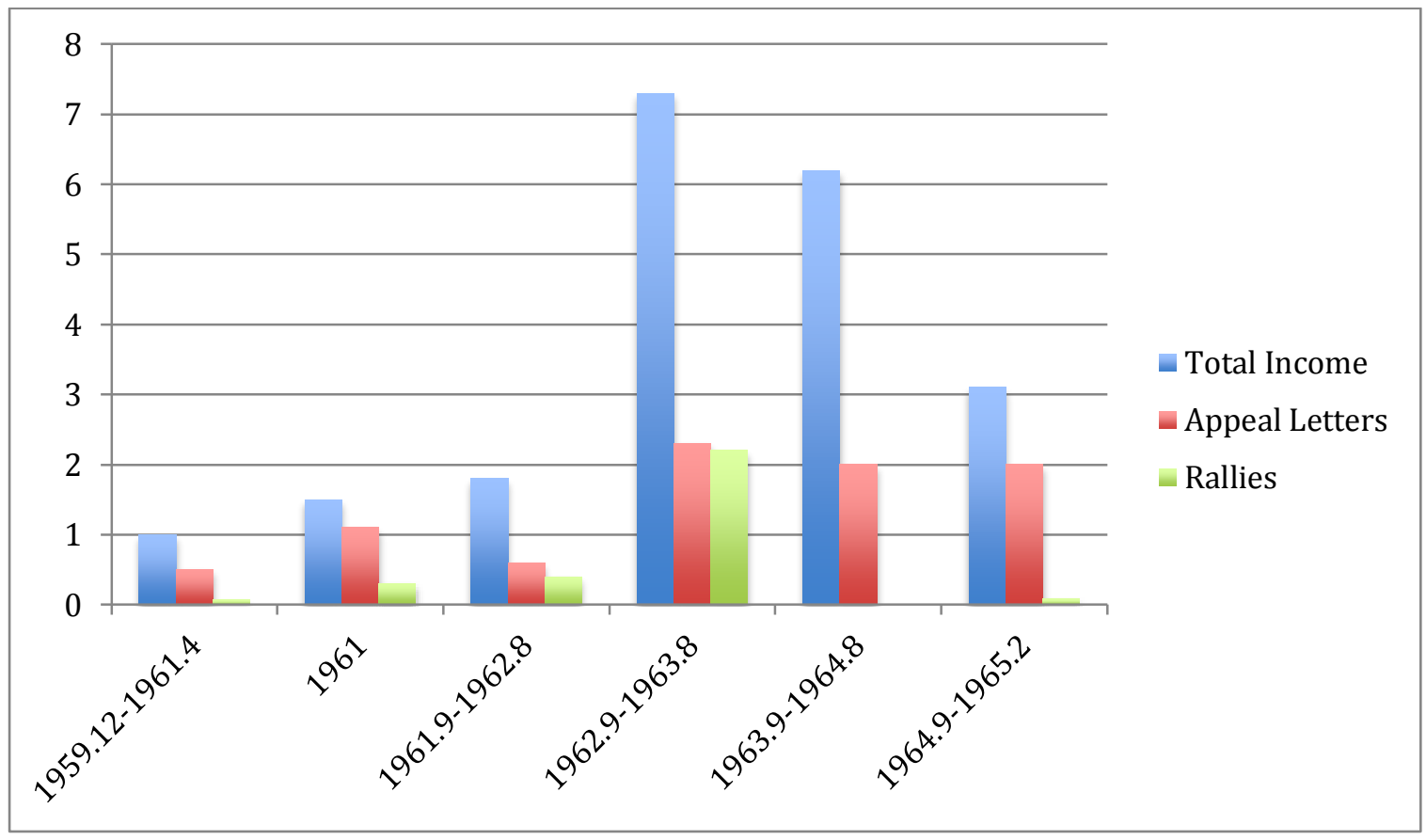

$* 1=$ A hundred thousand dollars on the left side. 


\section{Appendix B}

Note: This document is in "Citizenship School Workbook," HFS Archives.

\section{How To Fill In A Money Order Blank}

1. How the money order blank looks (simplified and slightly enlarged):

Front

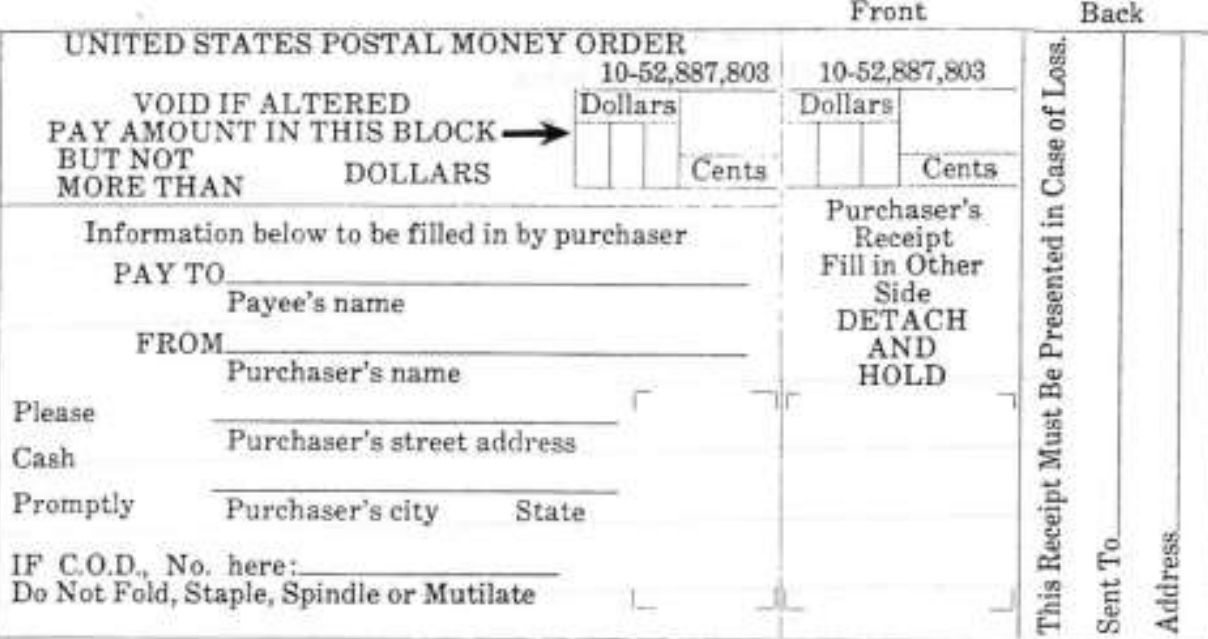

2. Where to fill in the blank:

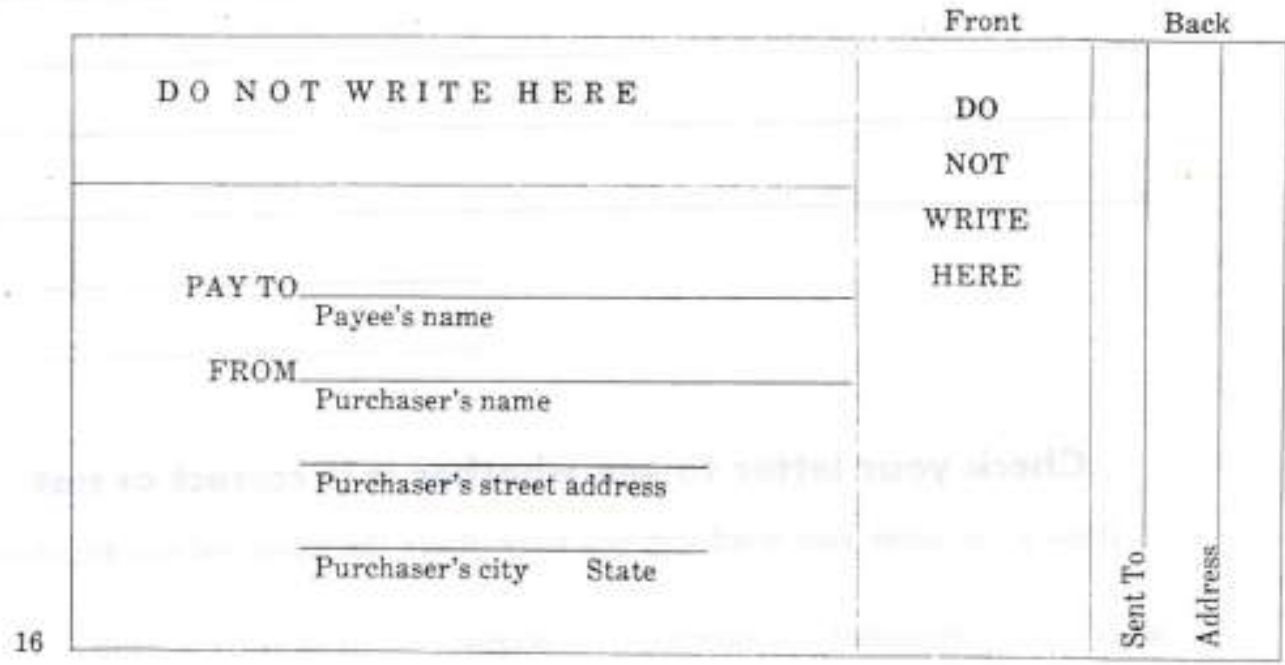




\section{Appendix C}

Note: This document is in "Citizenship School Workbook," HFS Archives.

\section{Sound Chart}

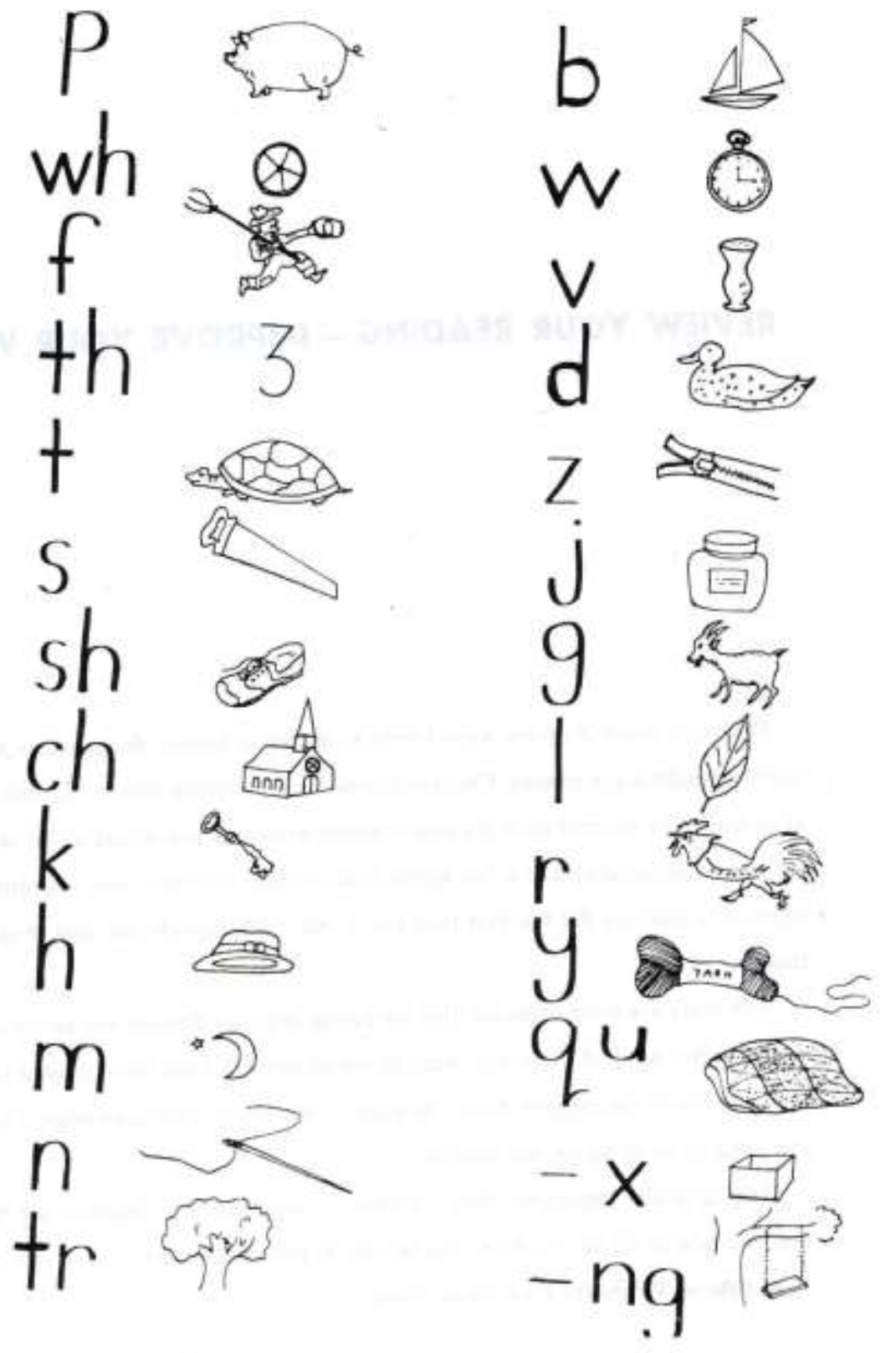




\section{Appendix D}

Questionnaire for Workshop on Training Leaders for Citizenship Schools

1. What were some of your problems in getting the Citizenship School Program started in your community? (These might be for instance problems of recruiting, finding a place to meet, ordering the right equipment and materials, overcoming community opposition, etc.)

Please explain:

2. What were the problems of operation? (Some of these perhaps were problems of keeping records, grouping the students into beginning and advanced sections, presenting text material, etc.)

Please explain:

3. What were some of the problems you had in getting along with your coworkers? (These might be problems of getting cooperation) misunderstanding of duties involved in the job, personal relationships and others.)

Please explain:

4. Please list any other kinds of problems: ${ }^{1209}$

1209 SCLC, The Test of the Citizenship School's Long Range Effect on Students," 1962, KPKC, 136:30. 


\section{Appendix E}

State of Alabama, "The Registration Process"

1. Q. Do you think everybody has a right to vote?

A. No. Criminals, feeble-minded or illiterate people should not.

2. Q. How many Senators do we have in the Senate?

A. 96. 2 from each state.

3. Q. How many Senators and Representatives do we have from the State of Alabama?

A. 11. 2 Senators and 9 Representatives.

4. Q. How many Representatives do we have in the House of Representatives?

A. 435 .

5. Q. How long do members of the House of Representatives serve?

A. 2 years.

6. Q. How long do members of the Senate serve?

A. 6 years.

7. Q. How old does an individual have to be before he can serve in the Senate?

A. 30 years.

8. Q. Name the Senator from this State?

A. Lister Hill and John Sparkman.

9. Q. How old does an individual have to be before he can serve in the House of Representatives?

A. 30 years.

10. Q. Who is our Representative from this district?

A. Laurie Battle.

11. Q. Who is the Secretary of State?

A. John Foster Dulles.

12. Q. Why does New York State have more representatives than Alabama?

A. Representatives are elected on the basis of population. Therefore, New

York is larger and she has the larger number of representatives.

13. Q. What form of Government have we in Birmingham?

A. Commission form.

14. Q. Name the City Commissioners.

A. Wade Bradley, James Morgan, Robert Lindbergh.

15. Q. Who is the County Sheriff?

A. Holt McHowell.

16. Q. Who is our Chief of Police?

A. E. H. Brown, Acting Chief.

17. Q. Who is the Probate Judge of Jefferson County?

A. Tom Garner.

18. Q. Who are the members of the County Commission?

A. W. D. Kendrick, President Charles Harrison and Eddie Gilmore.

19. Q. What are some of the qualifications of a voter?

A. He must be 21 in Jefferson County and three months in his precinct, one year in Jefferson County and 2 years in the State. He must own $\$ 300.00$ worth of personal property.

20. Q. Can an individual serve in the House of Representatives who has not reached the age of 25 ? 
A. No. An individual must be 25 years of age and he must have lived in the United States for 7 years and must have been elected from the State in which he resides.

21. Q. What is a felony?

A. A major crime.

22. Q. Who is the Governor of Alabama?

A. Gordon Persons. ${ }^{1210}$

1210 State of Alabama, “The Registration Process," KPKC, 138:8. 


\section{Appendix F}

\section{Interview with Dorothy Cotton}

Interviewer: Wook Jong Lee

March 28, 2018, New York.

Video Recordings by Kirby Edmonds

"Dr. Cotton, I am going to ask you some questions which need your answers to detail your thoughts and opinions concerning your religious origins and denominational backgrounds that impacted your involvement in the civil rights movement. In addition to your autobiography and oral history interview in 2011, please feel free to provide me with any detailed information to help me understand your background and the purposes of the CEP and the civil rights movement."

1. Did you have any religious experiences that led you to dedicate your life to the civil rights movement (any spiritual moment that impacted your decision to enter the civil rights movement)?

Cotton: I think it is really important. Kirby, that you, I, everybody will come to understand that sometime that just come a time, it's like, it's like getting a divorce. That comes a time when you know you can't stand and cook and wash, iron, scrub and sew, dig potato out of the ground, and...you can come a...that comes a time that one can't do that anymore. It wasn't a like a conscious decision, are you recording this help you are? It was not like a conscious decision, but I what I do know is that Martin emerged to something that we all started to honor and follow him and understand what he was talking about, when he would mention a nonviolence. And sometimes we'll be walking down the street, Martin come over something really brilliant, and... and we just talking, he was a jolly fellow. And I, I am trying to think what else, it was about... it was just about us be... being a team. And I will put it like that I don't want to give Martin so uh...that really way of put it, so much credit, that it sounds like he started us; he didn't. It started... as far as I'm concern, Highlander Folk School is the root, is a base, that I care that I was still living there. I got care one over the Highlander would. Just play some songs and we would sing all the time, and then have a discussion about what the CEP, Citizenship Education Program what it was all about, and it was all about the fact that we now had realized that they don't, none of them have a right to tell us what we can and cannot do. I am saying that it was awkwardly 'cause I was none of them, you probably think, who was them. But it was, it was...it was our need, for now, claiming our individuality. That's important.

2. Considering denominational church differences, did your African American Baptist church experience contribute to the development of your social activities or thinking about women's rights and grassroots leadership? How did the black Baptist church tradition shape your ideas for fighting against social injustice or working with the Baptist church leaders of SCLC? (For example, Ella Baker's 
black Baptist tradition impacted her struggles for women's self-determination and grassroots leadership.)

Cotton: It didn't. And I tell you what I didn't. We have a little show-fellow named Martin Luther King, and Martin, Martin could open his mouth, and poetry would roll out. And even if he would stop on the sidewalk, run in the park in the yard, what's pool, what's you guys play or this is man's play. Uh...some men's play. It's not every got play. Run in the poolroom, and was like tales were blending in a very awkward, kind of a way...Martin was involved in there, everybody was involved in that transitioning, and it gonna sound awkward, I think however you say it, it gonna sound awkward, but if you use, but put together the paragraphs, and I would try one, two, maybe I don't know. How it is that we now, were starting to feel out personhood, your manhood, more strongly, you will feel it more strongly now and why would you feel it, 'cause now you start to see the talent that this guys had, Martin Luther King. We started to see his talent, we started to see his ability to go with not a piece of paper in his hand, and make a speech, and to also explain something that we could...that we could absorb, is that a good word? We could absorb it. And I say we are, I mean, our team could absorb it. We could absorb it because Martin could say it, we could put it our language if we need to, but... it must...a...it is to say that Martin was uh...Martin was a lingui...he was a perfect, beautiful linguist. I think I really want to say that because he was a linguist. He could, Martin could take a phrase, make a poetry out of it very easily. And I, I think I like that to be said because it was really, really true that Martin, Martin could talk to guys on the sidewalk and it sounds like a poetry.

Assistant: But, it sounds like you are saying you were inspired by him, more than by church's teachings?

Cotton: More than by church's teachings? The church didn't teach us this. Martin told us it, Martin's walking down on the sidewalk with us, and he was talking all that poetic stuffs, and this, this came from Martin...(laugh). It didn't come from the...I don't even know I am gonna meditate on that, and if I get it out to call you...the...the church, the church couldn't handle what we were about. And I...it is hard for me to explain what I am saying, but it is hard for the church...I figured, yeh, anybody gonna say that you could. That couldn't explain, see the church, let my grandfather was a preacher, and it was easy for grandpa to just a whoop and a holler like an old fashion Baptist preacher would do. But they would very, very often just, as far as I was concerned, and my grandfather, they were just a kind of a whoop and a holler. I wanna say that without putting them down, you can put in them with some smoother languages to use that rather that, I don't wanna my grandpa down.

3. Graduates of the Citizenship School of the Highlander Folk School and of the CEP included Rosa Parks, Fannie Lou Hamer, Diane Nash, and you, and you were all essential civil rights women leaders. Did the Citizenship School of the HFS and the CEP have any specific curriculum or teachings for developing women's leadership? How did the Citizenship School raise up grassroots women leaders? 
Cotton: The...the Citizenship School was, brought consciousness. I really want to say, it brought consciousness because we were women now and I emphasize "the now," don't wanna leave the word out. It is very, very clear that women, strong women now start to take a leadership role. When early on, women couldn't do anything but say amen, tomorrow no, amen, some of preachers no, amen. And we knew we did not want to do that. I was very conscious of that. And I, so, if I am not just gonna sit around to say amen every time, Martin knows anybody else say something. It's a something that we did not accept, and I say we, I am talking about a woman did not accept that as the gospel or end all... and, and that's important because we were at a stage what we were transitioning into full recommendation you need, people need to know where we are. People need to know where, where we were, where we are, what we were arguing for at that time, and interestingly, women, the function in a woman was, it almost was like a creeping into the record, creeping into the culture and nobody made it happen, nobody said, is God to happen? May be they did, maybe I forgot that part, I don't know that, but it seems to me, no it doesn't seems to me, I know this is to be true that people who were in the civil rights movement now, knew that we are not going to sit back in that the men do all the works, get all the credits as they got the credit, they also push women back to a place of none recognition that is very, very important because we had very, very strong and powerful women, and you looking at one of them...(laugh), and there also other women, you know like Ella Baker, I was working in that movement...Ah...I'm gonna think some more names just in a minute I will help you put the women in some way, put them in the record, it is important that the women be in there because the women were like, you know, like Ella Baker, the women were also, just started to feel, I'm not gonna take this second-class citizenship anymore, women in the movement were starting to feel that very strongly. The question 2 from you will be very helpful...

Assistant: How did the Citizenship School help that?

Cotton: The...Highlander Folk School? was very powerful education, a little system. And, because the Citizenship School could do that the classes were going, we just kept doing it that we realized that we were successful, we were successful because now, it was not just men who were being trained, it was also woman, it was also Ella Baker, it was Dorothy Cotton, I'm gonna think about a bunch of more names, I'll probably on the phone with you...so just tell you who some of the women were, who got, who became very, very active, (assistant: Rosa Parks?) that was important that women became active because it, it was not, uh...it was kind of wake-up call happening around the country. Or at least in the park square, you know the Highlander Folk School was opening, was functioning now, and, and so to say there were other openings or good some more we could use of creative, uh...I got think about education and institution, there were other institutions that were very, very supportive of women as we were working in the civil rights movement and it's also that Martin liked to hanging around women...(laugh) Don't you tell me, he was.

4. I found that there were stories of Sojourner Truth and Harriet Tubman in the curriculum of the CEP's Citizenship School. In your opinion, did the legacies of Methodist women such as Sojourner Truth and Jarena Lee, who fought for 
abolition, contribute to shaping the unique civil rights activities of African Methodist Episcopal church women? Did they really impact the development of women leaders during the civil rights movement era?

Cotton: We knew and I say we are talking about the women now who have become very, very active in the civil rights movement. It is important to know at the point that you just highlighted. It is, it is important to know that those were or not just women, not just a, a woman, that's just what I wanna say, there were not just women who wanted to break those barriers that kept women from voting, for example, and you may know that there was a good bit of truth at that time, it was, it was, you know, my husband go to vote, not the woman, so, uh...I'm trying to think about I could strengthen that a little bit, but I would talk a lot about initially, that's a good word to use, initially it was the...uh, women and, I don't wanna say and the men, but it was the woman who got very, very active in voter operation, that's wrong word, voter..., voter activity, isn't that a good, I think it that's a good way to put it. It was the woman who got very..., you know, that was Ella Baker, that was Septima Clark, Septima was a fighter! That was Rosa...I said that was Rosa Parks, that there was two or three of the women who, who knew that something was wrong with the fact that only the men could vote. And we should spend a half day and eat a dinner or some uh...with this question. We have, I'm glad to doing this, we were not sure..., we were not sure that we were making sure the women were moving into active work in the voter process, but it was, it was like, it was happening and if, if this happening, then, you got somebody like me who was hanging around with Martin all the time, and they had taught me how to teach what the school did, the Highlander, and, and Martin knew I was good to teach, I already had a master's degree, and nobody else did...I think that should be highlighted that I became the education director and I think that was Martin... thing to do that to make me an education director. I got this master's degree from Boston University.

5. I found out that the Citizenship School changed the leadership structure of the civil rights movement from a top-down structure to a bottom-up one. Dr. King's tactics also dramatically changed after the Selma to Montgomery marches, such as for the Chicago Freedom Movement and the Poor People's Campaign.

Do you have any specific evidence that the success of the CEP's grassroots leadership impacted the change in King's focus from top-down leadership to bottom-up leadership (such as any changes in King's language, speeches, or attitude after the CEP's success)?

Cotton: I may have a say change in his tactics but when I saw his change in his tactics, I have to say to talk about I don't want to talk about... he was such a ...(laugh)...but I don't want that in record... because of Kirby, Martin, I remember it was, Andy and Bernard Lafayette, and...several of us were walking from the church up, up the street going to our meeting but we just had to walk from the church to the umh...where we were going on, where we were going on up to the meeting 'cause I have to say to Martin, don't you know it is time for you to be at the church right now, and I tried to get him to...he was in the poolroom 'cause we passed by the poolroom, and Martin he was like, he didn't 
care. He was having fun, he has a part of boys and a part of men. And I think that I know he enjoyed it. He was a part of playboy, a part...uh, he was a fun person. I wish you had met him. And I, if I would get it an active picture of him, you, I want you to put it in your library (laugh). So, you can write a book, and you can talk about Martin, or you want to talk about the babes, he had a lot of fun, hanging out with his team, that's a good way to put it, hanging out with his team. And make it sure that you talk about the fact that he liked to hanging out with us because we did. And he really did. I told you this, Martin went in the poolroom, and we were walking around, you know that street, and go down the pool and go down the street, and, uh, Martin looked always, guess playing pool, guess a way he wins, he went to the poolroom. That's right.

6. The CEP hired Bernice Robinson as a part-time or half-time director, right? There is an interview with Robinson in which she said, "I never worked for the CEP as a full-time director." She did this because she wanted to remain as the full-time director of the Highlander Folk School, and she didn't want to spend too much money from the Marshall Field scholarship on a salary for her. Is this right? I want to make it clear.

Cotton: That may have a part-time. I just wanna make it sure, Bernice never directed anything. She and Septima were kind of a team because they had always been a team when they were back at just in the Highlander Folk School, but, but she, she Bernice become good just a colleague working together, and I think it's good to say that they became a kind of a team, but, but don't get Bernice the directorship, she was, she didn't have that skill. One of our CEP teachers, and that's all I can say for her. And I am now the director, and Martin made me director.

\section{Extra questions}

On page 220 of your If Your Back's Not Bent, you say that a white girl's prayer at a staff retreat inspired Dr. King's "I Have a Dream" speech. However, according to James Bevel, Prathia Hall, who was an African American woman activist of SNCC, inspired Dr. King when she prayed during the commemoration service for the burned Mount Olive Baptist Church. Did these two young people inspire King, or is there discord between Bevel's remembering and yours?

Cotton: I don't...I don't fancy any young people's inspiring. Even though he might take a phrase from what you might say, I might say or somebody might say, he might take a phrase, when he got through the phrase, he got two or three-page speech, and that was one of Martin's talents. It really was. He could take a phrase and he could feel the pages and more, because he knew there were different ways to explain it to our folks. My dad would know what he is talking about very often. But Martin would go after...but he somehow, Martin would able to say in a way that even my dad could understand it, who didn't finish high school. He could, he could say, I think he loved being able to do that. And to be able to finish, you know, the advanced degrees, and this is very special because it's like Martin could talk to anybody and...that's OK, he could talk to anybody and he knew what he wanted to say them and he knew a way to say it. 


\section{Bibliography}

Adams, Frank. Unearthing Seeds of Fire: The Idea of Highlander. In collaboration with Myles Horton. Winston-Salem: John F. Blair, 1998.

Andrews, William L, ed. Sisters of the Spirit: Three Black Women's Autobiographies of the Nineteenth Century. Bloomington: Indiana University Press, 1986.

Baer, Hans A. and Merrill Singer, African American Religion: Varieties of Protest and Accommodation. Knoxville: The University of Tennessee Press, 2002.

Baldwin, Lewis V. Never to Leave Us Alone: The Prayer Life of Martin Luther King, Jr. Minneapolis: Fortress Press, 2010.

Branch, Taylor. At Canaan's Edge: America in the King Years, 1965-68. New York: Simon \& Schuster Paperbacks, 2006.

---. Parting the Waters: America in the King Years, 1954-63. New York: Simon \& Schuster Paperbacks, 1988.

---. Pillar of Fire: America in the King Years, 1963-65. New York: Simon \& Schuster Paperbacks, 1998.

---. The King Years: Historic Moments in the Civil Rights Movement. New York: Simon \& Schuster, 2013.

Cagin, Seth. and Philip Dray. We Are Not Afraid: The Story of Goodman, Schwerner, and Chaney and the Civil Right Campaign for Mississippi. New York: Nations Book, 2006.

Carson, Clayborne. In Struggle: SNCC And the Black Awakening of the 1960s. Cambridge: Harvard University Press, 1981.

Clark, Septima P. Echo in My Soul. Edited by LeGette Blythe. New York: E. P. Dutton and Co., 1962.

---. Ready from Within: Septima Clark and the Civil Rights Movement.

Edited by Cynthia Stokes Brown. Trenton: Africa World Press, 1990.

Cobb, James C. "The Voting Rights Act 50: How It Changed World," Time Magazine. August 6, 2015.

Collier-Thomas, Bettye. Jesus, Jobs, and Justice: African American Women and Religion. New York: Alfred A. Knopf, 2010.

---. and V. P. Franklin, eds. Sisters in the Struggle: African American Women in the Civil Rights-Black Power Movement. New York: New York University Press, 2001.

Cone, James H. Black Theology and Black Power. Maryknoll: Orbis Books, 2001. 
Copeland, M. Shawn, ed. Uncommon Faithfulness: The Black Catholic Experience. Maryknoll: Orbis Books, 2009.

Cotton, Dorothy F. If Your Back's Not Bent: The Role of the Citizenship Education Program in the Civil Rights Movement. New York: Atria Books, 2012.

DeRoche, Andrew J. Andrew Young: Civil Rights Ambassador. Wilmington, DE: Scholarly Resources Inc., 2003.

Deedy, John. American Catholicism: And Now Where? New York: Plenum Press, 1987.

Dittmer, John. Local People: The Struggle for Civil Rights in Mississippi. Urbana: University of Illinois Press, 1994.

Dodson, Jualynne E. Engendering Church: Women, Power, and the AME Church.

Lanham: Rowman \& Littlefield Publishers, INC., 2002.

Drake, St. Clair. and Horace R. Cayton. Black Metropolis: A Study of Negro Life in a Northern City. Chicago: University of Chicago Press, 1993.

Dyson, Michael Eric. April 4, 1968: Martin Luther King, Jr. 's Death and How It Changed America. New York: Basic Civitas Books, 2008.

---. I May Not Get There with You: The True Martin Luther King, Jr. New York: The Free Press, 2000.

Estes, Steve. Charleston in Black and White: Race and Power in the South after the Civil Rights Movement. Chapel Hill: University of North Carolina Press, 2015.

Fairclough, Adam. To Redeem the Soul of America: The Southern Christian Leadership Conference and Martin Luther King, Jr. Athens: The University of Georgia Press, 1987.

Fradin, Dennis Brindell. and Judith Bloom Fradin. Ida B. Wells: Mother of the Civil Right Movement. New York: Clarion Books, 2000.

Gaines, Kevin K. Uplifting the Race: Black Leadership, Politics, and Culture in the Twentieth Century. Chapel Hill: The University of North Carolina Press, 1996.

Garrow, David J. Bearing the Cross: Martin Luther King, Jr. and the Southern Christian Leadership Conference. New York: Perennial Classics, 1999.

---. Protest at Selma: Martin Luther King, Jr., and the Voting Rights Act of 1965. New Haven: Yale University Press, 1978.

Gates, Jr., Henry Louis, ed. Narrative of Sojourner Truth, A Bondswoman of Olden Time, with a History of Her Labors and Correspondence Drawn from Her "Book of Life". New York: Oxford University Press, 1991. 
Giddings, Paula. When and Where I Enter: The Impact of Black Women on Race and Sex in America. New York: William Morrow and Company, INC., 1984.

Gillis, Chester. Roman Catholicism in America. New York: Columbia University Press, 1999.

Glen, John M. Highlander: No Ordinary School 1932-1962. Lexington: University Press of Kentucky, 1988.

Grant, Joanne. Ella Baker: Freedom Bound. New York: John Wiley and Sons, 1998.

Greenhaw, Wayne. Fighting the Devil in Dixie: How the Civil Rights Activists Took on the Ku Klux Klan in Alabama. Chicago: Lawrence Hill Books, 2011.

Hall, Heidi. "Years After Change, Activist Lives Her Convictions," USA Today. March 26, 2013.

Hartford, Bruce. The Selma Voting Rights Struggle \& the March to Montgomery. San Francisco: Westwind Writers, 2014

Height, Dorothy I. Open Wide the Freedom Gates: A Memoir. New York: Public Affairs, 2003.

Higginbotham, Evelyn Brooks. Righteous Discontent: The Women's Movement in the Black Baptist Church, 1880-1920. Cambridge: Harvard University Press, 1993.

Holsaert, Faith S. et al., eds. Hands on the Freedom Plow: Personal Accounts by Women in SNCC. Urbana: University of Illinois Press, 2010.

Honey, Michael K. Going Down Jericho Road: The Memphis Strike, Martin Luther King's Last Campaign. New York: W. W. Norton, 2008.

Horton, Myles. The Long Haul: An Autobiography. New York: Teachers College Press, 1998.

Jackson, J. H. A Story of Christian Activism: The History of the National Baptist Convention, U.S.A., Inc. Nashville: Townsend Press, 1980.

Jackson, Thomas F. From Civil Rights to Human Rights: Martin Luther King, Jr. and the Struggle for Economic Justice. Philadelphia: University of Pennsylvania Press, 2007.

Johnson, Karen A. Uplifting the Women and the Race: The Educational Philosophies and Social Activism of Anna Julia Cooper and Nannie Helen Burroughs. London: Routledge Publishing, 2000.

Karpiel, Frank. Charleston's Historic Cemeteries. Charleston: Arcadia Publishing, 2013.

Kaufman, Polly Welts, Jean Gibran, Sylvia McDowell, and Mary Howland Smoyer. Boston Women's Heritage Trail: Seven Self-guided Walks Through Four Centuries of Boston Women's History. Boston: Boston Women's Heritage Trail, 2006. 
Keller, Rosemary Skinner. and Rosemary Radford Ruether, eds. Encyclopedia of Women and Religion in North America. Bloomington: Indiana University Press, 2006.

King, Coretta Scott. My Life, My Love, My Legacy: As Told to the Rev. Dr. Barbara Reynolds. New York: Henry Holt and Company, 2017.

---. My Life with Martin Luther King, Jr. New York: Holt, Rinehart and Winston, 1969.

King, Martin Luther, Jr. “All Labor Has Dignity.” Edited by Michael K. Honey. Boston: Beacon Press, 2011.

---. Stride Toward Freedom: The Montgomery Story. Boston: Beacon Press, 2010.

---. The Autobiography of Martin Luther King, Jr. Edited by Clayborne Carson. New York: Warner Books, 1998.

---. The Papers of Martin Luther King, Jr. Vol. 1. Edited by Claryborne Carson, Ralph E. Luker, and Penny A. Russell. Berkeley: University of California Press, 1992.

---. The Papers of Martin Luther King, Jr. Vol. 2. Edited by

Clayborne Carson, Ralph E. Luker, Penny A. Russell, and Peter Holloran. Berkeley: University of California Press, 1994.

---. The Papers of Martin Luther King, Jr. Vol. 4. Edited by Susan

Carson, Adrienne Clay, Virginia Shadron, and Kieran Taylor. Berkeley:

University of California Press, 2000.

---. The Papers of Martin Luther King, Jr. Vol. 5. Edited by Clayborne Carson, Tenisha Armstrong, Susan Carson, Adrienne Clay and Kieran Taylor. Berkeley: University of California Press 2005.

---. The Papers of Martin Luther King, Jr. Vol. 6. Edited by Clayborne Carson, Susan Carson, Susan Englander, Tory Jackson and Gerald L. Smith. Berkeley: University of California Press, 2007.

King, Martin Luther, Sr. Daddy King: An Autobiography. New York: William Morrow, 1980.

Lee, Chana Kai. For Freedom's Sake: The Life of Fannie Lou Hamer. Urbana: The University of Illinois Press, 1999.

Levine, Daniel. Bayard Rustin and the Civil Rights Movement. New Brunswick: Rutgers University Press, 2000.

Lewis, David Levering, ed. The Portable Harlem Renaissance Reader. New York: Penguin Books, 1994.

Lewis, John. Walking with the Wind: A Memoir of the Movement. New York: Simon \& Schuster, 1998. 
Lincoln, C. Eric. and Lawrence H. Mamiya. The Black Church in the African American Experience. Durham: Duke University Press, 1990.

McGuire, Danielle L. At the Dark End of the Street. New York: Vintage Books, 2010.

Mabee, Carleton. and Susan Mabee Newhouse. Sojourner Truth: Slave, Prophet, Legend. New York: New York University Press.

Mantler, Gordon Keith. "Black, Brown, and Poor: Martin Luther King, Jr., the Poor People's Campaign and Its Legacies.” PhD diss., Duke University, 2008.

Marsh, Charles. God's Long Summer: Stories of Faith and Civil Rights. Princeton: Princeton University Press, 1997.

---. The Beloved Community: How Faith Shapes Social Justice, from the Civil Rights Movement to Today. New York: Basic Books, 2005.

Mills, Kay. This Little Light of Mine: The Life of Fannie Lou Hamer. Lexington: The University Press of Kentucky, 2007.

Morris, Aldon D. The Origins of the Civil Rights Movement: Black Communities Organizing for Change. New York: The Free Press, 1984.

Moses, Robert P. and Charles E. Cobb, Jr. Radical Equations: Civil Rights from Mississippi to the Algebra Project. Boston: Beacon Press.

Murphy, Larry G, ed. Down by the Riverside: Readings in African American Religion. New York: New York University Press, 2000.

Oates, Stephen B. Let the Trumpet Sound: The Life of Martin Luther King, Jr. New York: Harper \& Row, 1982.

Ochs, Stephen J. Desegregating the Altar: The Josephites and the Struggle for Black Priests, 1871-1960. Baton Rouge: Louisiana State University Press, 1990.

Olson, Lynne. Freedom's Daughters: The Unsung Heroines of the Civil Rights Movement from 1830 to 1970. New York: Touchstone, 2001.

Parks, Rosa. and Gregory J. Reed. Quiet Strength: The Faith, the Hope, and the Heart of a Woman Who Changed a Nation. Grand Rapids: Zondervan Publishing House, 1994.

---. and Jim Haskins, My Story. New York: Puffin Books, 1992.

Phillips, Donald T. Martin Luther King, Jr. on Leadership: Inspiration and Wisdom for Challenging Times. New York: Business Plus, 1998.

Raboteau, Albert J. Slave Religion: The "Invisible Institution” in the Antebellum South. New York: Oxford University Press, 2004. 
Randolph, A. Philip. For Jobs and Freedom: Selected Speech and Writings. Edited by Andrew E. Kersten and David Lucander. Amherst: University of Massachusetts Press, 2014.

Ransby, Barbara. Ella Baker and the Black Freedom Movement. Chapel Hill: University of North Carolina Press, 2003.

Richardson, Christopher M. and Ralph E. Luker. Historical Dictionary of the Civil Rights Movement, $2^{\text {nd }}$ Edition. New York: Rowman \& Littlefield, 2014.

Riggs, Marcia Y, ed. Can I Get a Witness? Maryknoll: Orbis Books, 1997.

Robinson, Jo Ann Gibson. The Montgomery Bus Boycott and the Women Who Started It: The Memoir of Jo Ann Gibson Robinson. Knoxville: University of Tennessee, 1987.

Ross, Rosetta E. Witnessing \& Testifying: Black Women, Religion, and Civil Rights. Minneapolis: Fortress Press, 2003.

Still, Larry. "Economic Pressure Against 5,000 Families Affects 22,000 People," Jet Magazine. Feb. 21, 1963.

Sutton, Marie A. A. G. Gaston Motel in Birmingham: A Civil Rights Landmark. Charleston: The History Press, 2014.

Swanson, Craig. The Selma Campaign: Martin Luther King, Jr., Jimmie Lee Jackson, and the Defining Struggle of the Civil Rights Era. Bloomington: ArchwayPublishing, 2014.

Terrell, Mary Eliza Church. A Colored Woman in a White World. Washington, DC: Ransdell Inc. Printers and Publishers, 1940.

Uschan, Michael V. James Forman and SNCC. Detroit: Lucent Books, 2013.

Visser-Maessen, Laura. Robert Parris Moses: A Life in Civil Rights and Leadership at the Grassroots. Chapel Hill: The University of North Carolina Press, 2016.

Wells, Ida B. The Light of Truth: Writings of an Anti-Lynching Crusader. Edited by Henry Louis Gates, Jr. New York: Penguin Books, 2014.

---. The Memphis Diary of Ida B. Wells. Edited by Miriam DeCosta-Willis. Boston: Beacon Press, 1995.

West, Cornel. Prophesy Deliverance! An Afro-American Revolutionary Christianity. Louisville: Westminster John Knox Press, 2002.

Young, Andrew. An Easy Burden: The Civil Rights Movement and the Transformation of America. New York: HarperCollins Publishers, 1996.

Zinn, Howard. SNCC: The New Abolitionist. Chicago: Haymarket Books, 1964. 


\section{Web Sources}

American Experience PBS. "Fannie Lou Hamer's Powerful Testimony." an excerpt from Freedom Summer. June 24, 2014, YouTube Video, 3:40. https://www.youtube.com/watch?v=07PwNVCZCcY.

Baker, Ella. "Address at the Hattiesburg Freedom Day Rally.” January 21, 1964. In http://voicesofdemocracy.umd.edu/ella-baker-freedom-day-rally-speech-text/.

Britton, John. “Oral History/Interview Ella Baker 1968.” In the Civil Rights Documentary Project, 1968. http://www.crmvet.org/nars/baker68.htm\#baker68_family.

Evers, Medgar. Medgar Evers to Amzie Moore, April 19, 1960. In Wisconsin Historical Society, Freedom Summer Collection, 1:4. http://content.wisconsinhistory.org/cdm/ref/collection/p15932coll2/id/21902.

Hamer, Fannie Lou. "Testimony before the Credentials Committee, DC Convention." August 22, 1964, American Rhetoric. http://www.americanrhetoric.com/speeches/fannielouhamercredentialscommittee.htm.

"Interview with Coretta Scott King." April, 18, 2008. YouTube Video, 1:18. https://www.youtube.com/watch?v=5lzVxVZcdsY.

Jackson, L. K. L. K. Jackson to President Kennedy, 1963. In KPKC of the Digital Archive. http://www.thekingcenter.org/archive/document/letter-l-k-jacksonpresident-kennedy.

"March on Washington for Jobs and Freedom." Lincoln Memorial program, Civil Rights Movement Veterans. http://www.crmvet.org/docs/mowprog.pdf.

Michael Fletcher, "An Oral History of the March on Washington.” Smithsonian Magazine. July 2013. https://www.smithsonianmag.com/history/oral-history-march-washington$180953863 /$.

National Park Service, U.S. Department of the Interior. "Old Bethel United Methodist Church." https://www.nps.gov/nr/travel/charleston/obm.htm.

New York Public Radio Archives \& Preservation, "Interview with the Civil Rights Legend Fannie Lou Hamer in August of 1964." http://www.wnyc.org/story/interview-civil-rights-legend-fannie-lou-hamer/. "Oral history interview with Fannie Lou Hamer, Negro, woman, FDP: member of ex com." 0491, Ruleville, Mississippi. https://exhibits.stanford.edu/project-south/catalog/zb317wv2717.

Southern Christian Leadership Conference. "Dr. King and the SCLC_Powerful Action 
for Change." March 31, 1968.

http://www.crmvet.org/docs/6803_sclc_4change.pdf.

Student Nonviolent Coordinating Committee. "Digital SNCC Gateway."

https://snccdigital.org/people/annell-ponder/.

The Civil Rights History Project, U.S., Joseph Mosnier, and Dorothy F. Cotton, Dorothy Foreman Cotton Oral History Interview Conducted by Joseph Mosnier in Ithaca, New York, 2011-07-25. Ithaca, New York, July 25, 2011. Video. Retrieved from the Library of Congress. (Accessed November 3, 2017). https://www.loc.gov/item/afc2010039_crhp0040/.

The New York Public Library, "Biographical Sketch.” In Ella Baker Papers 1926-1986. http://archives.nypl.org/uploads/collection/pdf_finding_aid/scmmg630.pdf.

Transcript of an interview with Fannie Lou Hamer, June 1963, http://www.crmvet.org/nars/63_flh_winona.pdf.

Walker, Eugene. “Oral History Interview with Ella Baker.” September 4, 1974. Interview G-0007. Southern Oral History Program Collection. http://docsouth.unc.edu/sohp/G-0007/excerpts/excerpt 8074.html. http://docsouth.unc.edu/sohp/G-0007/excerpts/excerpt_8077.html. http://docsouth.unc.edu/sohp/G-0007/excerpts/excerpt 8078.html. http://docsouth.unc.edu/sohp/G-0007/excerpts/excerpt_8081.html.

Walker, Wyatt Tee. "Report of the Director to the Executive Board." October 11, 1960. http://www.crmvet.org/docs/6010_sclc_wyatt_report.pdf. 